Raquel Fraga e Silva Raimondo

11

Proteinograma da secreção

10

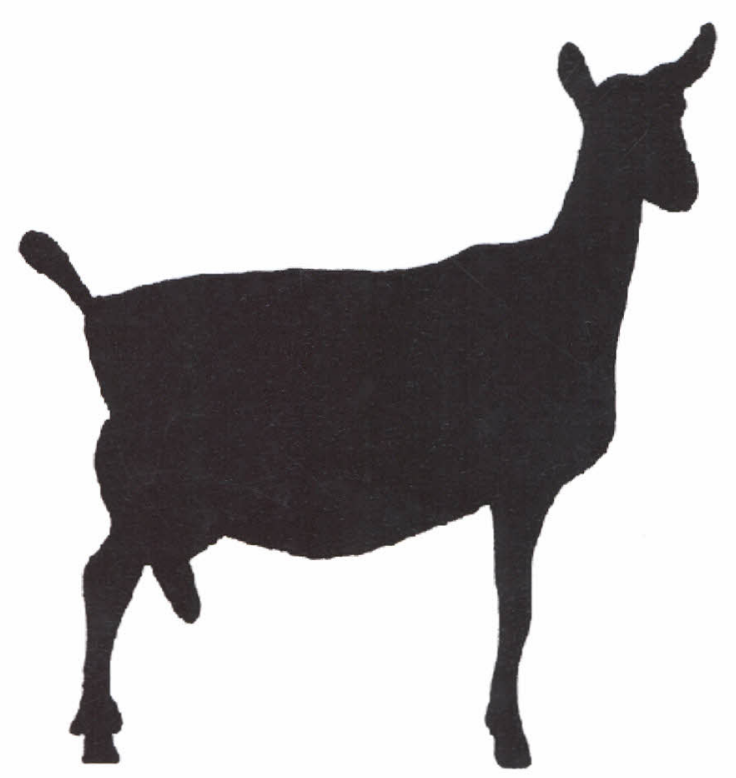


Raquel Fraga S. Raimondo

\section{Proteinograma da secreção láctea de cabras}

Tese apresentada ao Programa de Pós graduação em Clínica Veterinária da Faculdade de Medicina Veterinária e Zootecnia da Universidade de São Paulo para obtenção do título de Doutor em Ciências

Departamento:

Clínica Médica

Área de concentração:

Clínica Veterinária

Orientador:

Profo Dr. Eduardo Harry Birgel Junior 
Autorizo a reprodução parcial ou total desta obra, para fins acadêmicos, desde que citada a fonte.

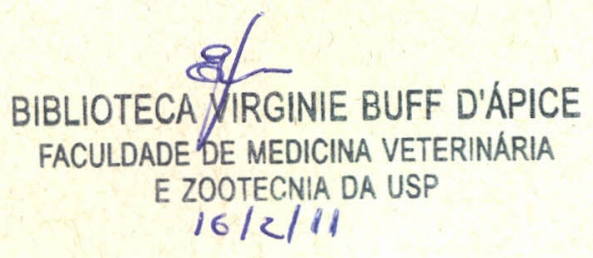

DADOS INTERNACIONAIS DE CATALOGAÇÃO-NA-PUBLICAÇÃO

(Biblioteca Virginie Buff D’Ápice da Faculdade de Medicina Veterinária e Zootecnia da Universidade de São Paulo)

Raimondo, Raquel Fraga S.

Proteinograma da secreção láctea de cabras / Raquel Fraga S. Raimondo. -- 2011

$148 \mathrm{f}$. : il.

Tese (Doutorado) - Universidade de São Paulo. Faculdade de Medicina Veterinária e Zootecnia. Departamento de Clinica Médica, São Paulo, 2011.

Programa de Pós-Graduação: Clínica Veterinária. Área de concentração: Clínica Veterinária.

Orientador: Prof ${ }^{\circ}$ Dr. Eduardo Harry Birgel Junior.

1. Cabra. 2. Proteína do soro de leite. 3. Eletroforese SDS-PAGE. 4. Artrite e encefalite caprina. 5. Fase de lactação. I. Título. 


\section{UNIVERSIDADE DE SÃO PAULO \\ Faculdade de Medicina Veterinária e Zootecnia \\ Comissão Bioética}

\section{CERTIFICADO}

Certificamos que o Projeto intitulado "Proteinograma da secreção láctea de caprinos", protocolado sob o n $1093 / 2007$, utilizando 221 (duzentos e vinte e um) caprinos (amostras de leite colhidas por ordenha trivial), sob a responsabilidade do Prof. Dr. Eduardo Harry Birgel Júnior, está de acordo com os princípios éticos de experimentação animal da Comissão de Bioética da Faculdade de Medicina Veterinária e Zootecnia da Universidade de São Paulo e foi aprovado em reunião do dia 17 de abril de 2007.

(We certify that the Research "Goat milk proteinogram", protocol number 1093/2007, utilizing 221 (two hundred and twenty one) goats, under the responsibility Prof. Dr. Eduardo Harry Birgel Júnior, agree with Ethical Principles in Animal Research adopted by Bioethic Commission of the School of Veterinary Medicine and Zootechny of University of São Paulo and was approved in the meeting of the day 04/17/2007).

São Paulo, 20 de abril de 2007

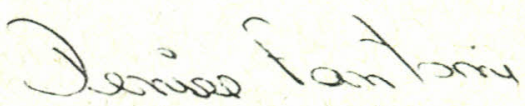

Profa Dra Denise Tabacchi Fantoni

Vice-Presidente da Comissão de Bioética

FMVZ/USP 


\section{FOLHA DE AVALIAÇÃO}

Nome: RAIMONDO, Raquel Fraga e Silva

Título: Proteinograma da secreção láctea de cabras

Tese apresentada ao Programa de PósGraduação em Clínica Veterinária da Faculdade de Medicina Veterinária e Zootecnia da Universidade de São Paulo para obtenção do título de Doutor em Ciências

Data:

\section{Banca Examinadora}

Prof. Dr

Assinatura:

Prof. Dr

Assinatura:

Prof. Dr

Assinatura:

Prof. Dr

Assinatura:

Prof. Dr

Assinatura:
Instituição:

Julgamento:

Instituição:

Julgamento:

Instituição:

Julgamento:

Instituição:

Julgamento:

Instituição:

Julgamento: 
Têm o dom de ver estradas aonde eu vejo o fim

Me convencem quando falam: não é bem assim!

se me esqueço - me recordam,

senão sél-me ensinam,

se perco a direção vêm me encontrar

Têm o dom de ouvir segredos, mesmo se me calo,

se falo me escutam querem compreender (e como falo as vezes)

Quando as atividades da pós me tíraram do convivio

A força da saudade me fez retornar

Quando eu não soube compreender a vida,

vocês vieram compreender por mím

Quando os meus olhos não podiam ver

Tuas mãos seguras me ajudaram a andar

Quando os meus sonhos vi desmoronar

Me trouxeram outros para recomeçar

Quando me esqueci que era alguém na vida

Seu amor véio me relembrar:

Que eu não estou só, que Deus cuida de mim,

Quando fala por vocês

Que sempre estarão comigo

Me dizendo: coragem!

Portudo isso e muito mais

\section{Aos meus pais}


A Rebeca, minha irmã e atriz preferida que me apresenton Elsa a vaca que dançava sobre a lua... sempre me alegrou e "zuou" descontraindo os momentos mais tensos 
Ao meu orientador Profo Dr. Eduardo Harry Birgel Junior

Pelos desafíos propostos, pela insistência exigências que me fizeram crescere progredir e principalmente pela confiança e apoio para que tudo se tornasse possivel.

Ao Buiatra Eduardo Harry Birgel Junior

Idealizador do centro de Pesquisa e Diagnóstico de Enfermidades de Ruminantes (CPDER), que me ensinou a arte da clínica veterináría e a beleza do diagnóstico, com o seu contagiante amor e dedicação ao examine dos ruminantes

Ao amigo Eduardo e família

Pela acolhida sempre agradável em sua casa, pelas longas e agradáveis conversare pelos conselhos sobre diferentes assuntos da vida, desde politica até as vitórias e decepções do nosso glorioso Timão. A paniela pela amizade, carinho, atenção e ensinamentos. Aos pequenos, Bía, Isabele e Henrique pela alegria, brincadeíras e sorrisos.

As especialistas em laboratório clínico do VCM

\section{Samantha Ive Miyashiro e clara Mori}

Pela grandiosa ajuda na padronização das técnicas de eletroforese e biureto para soro lácteo e no processamento das infinitas amostras, pelos ensinamentos de patología clinica e procedimentos Laboratoriais, pela paciência (muita paciêncía) e dedicação em todos os momentos desse trabalho, pelos exemplos de competência

As amigas

Samantha - pela amizade construida, pelas conversas e conselhos, pelos "tapões" e broncas, pela companhía e risadas nas longas tardes e noites no laboratório e nos churrascos no ruminantes

clara - pela amizade construida, pelas conversas, conselhos e risadas, pela companhía nos almoços e nos dias no laboratório

Por tudo que fizeram, por tudo que me ensinaram e principalmente pela amizade Agradeço! 
Profo Dr. João Paulo Elsen saut men amigo mala, um "eletroforético", obrigada pelos ensinamentos da técnica de eletroforese, pelas intermináveis horas de laboratório, pelas conversas, viagens e principalmente pela amizade verdadeira.

Aos médicos veterinários MSc. Ana Paula Mazzuco Prina (Nel) e MSc. Flavio Brandespim, meus hilarios amigos, companheiros de inesqueciveis viagens de colheitas e horas de laboratório, obrigada pelas conversas e desabafos, pelo incentivo e torcida e principalmente pela imensa ajuda na colheita das amostras para o estudo da fase de secagem dessa tese.

A médica veterinaria MSc. Mariana Tikuma Nunes amiga de estágio, mestrado, viagens (em que o carro quebrava sempre), obrigada por tudo, principalmente por me acolher em sua casa em Pirassununga e me apoiar nos momentos decísivos de correções desse trabalho.

Ao querido Profo Dr. Fabio Celidonio Pogliani, "meu orgulho", mas em primeiro lugar meu amigo, companheiro de viagens de colheitas, de disciplinas, congressos, relatórios, corridas impagáveís para a FAPESP (sempre da tempo), videos hílários do "you tube", conversas e momentos engraçados na salinha. O que tudo sabe e se não sabe, sabe aonde encontrar. Obrigada pelos momentos impagáveís! ERBA!

Ao médico veterinário MSc. Leandro Lipinski, o representante do sul, obrigada pelos conselhos e conversas

Ao médico veterinário Bruno Moura Monteiro o representante do Norte, sempre delicado e preocupado em ajudar, companheiro de disciplinas, conversas e momentos engraçados na salinha.

A médica veterináría Melina Marie Yasuolea, minha querida "pequena" Mel, obrigada pelos sermões (mesmo não respeitando as hierarquías, rs), pelas conversas, pelo carinho, otimismo, pelas risadas, torcida e amizade, companheira de frío e noítes mal e não dormidas, de trabalho, viagens, churrascos e videokês. obrigada por tudo! 
A Fundação de Amparo a Pesquisa - FAPESP, pelo apoí financeiro sem o qual tudo se tornaría mais dificíl

A zootecnista carla F. Noznica pelos contatos com os criadores de cabras, pelas conversas sempre agradaveis e trocas de experiências e pelo auxilio nas colheitas no sitio Rekantinho.

Aos proprietario Sr vicente Ríbeiro do capríl são Paulo, a Sra Marilía Pasin do capril paraiso da Mantiqueira, ao Méd. Vet. Denis catto da Quéjjaría chamonix por gentilmente permitirem a colheita de amostras em suas propriedades e aos seus funcionarios em especial a Dona Eva (Chamonix) pela prestativa ajuda e paciência durante as colheitas

A Claudia Strangnolo especialista responsavel pelo laboratório de imunología e microbiología do VCM, pela grandiosa ajuda na realização dos exames de CAE $e$ microbiológíco das amostras e pelos ensinamentos, carinho e dedicação.

A carmem Ribeiro técnica do laboratório de pesquisa, pelo carinho e dedicação na preparação dos materiais, pela companhía sempre agradável nas infinitas horas no laboratório, pelas conversas e amizade.

A María Helena e Mau do Laboratório de hematología e a Marly do Laboratórío de bioquímica, pelos ensinamentos, conversas e convivio

As secretárías cída e Adelaíde pelo pronto auxilio sempre que necessitéi

As ics Juliana Ferrão (Danete), Cinthía Nacamura pelo auxilio na padronização da técnica de eletroforese e a Fernanda Maciel (Bronha) pelo auxilio nas colheitas e processamento das amostras

A todos os funcionários da Biblioteca Vírginie Buff D'Ápice sem exceção, pela atenção, carinho e competêncía nos serviços prestados

Aos funcionários do hospital de bovinos e pequenos ruminantes, Luizinho, sr. Edson, Francisco pelo auxílio e manutenção das cabras

Ao Profe Dr. José Luiz D'Angelino, men eterno orientador, por despertar em mim o amor pela pesquisa e principalmente por tudo que me ensinon e me ensina

A todos os profos do VCM pelos ensinamentos passados e pelo convivio, em especial, aos professores de ruminantes Fernando josé Benesi, Lílian Gregory. Alice Della Libera, María Claudia Sucupira, Enrico ortolani, por tudo que me ensinaram des de os tempos de estágío, por todo carínho e dedicação e a "caçula" Víviani Gomes pelas conversas e amizade

Ao profe Dr. José Jurandir Fagliari - UNESP/Jaboticabal pelo auxílio com a técnica de eltroforese

A profa, amiga e colega Elizabeth Bohland, pelos ensinamentos nos tempos de faculdade, pelas conversas, conselhos nos tempos de pós-graduação e pela amizade

A profa Dra Mitíka Hagiwara pela oportunidade de fazer parte da VIII turma do curso de especialização em Patología clínica e pelos ensinamentos passados 
A VIII turma do curso de especialização em Patología clínica veterinaría da USP, por me acolher, pelas trocas de experiências, pela ajuda e paciência nas aulas, pela torcida na conclusão desse estudo e principalmente pela amizade, em especial Adriele cardoso (abestada Paraense), Monica Barbella e Fabio Capuani

Aos amigos da pós Laura, Juliana e camila companheiras desde os tempos de estagío Frederico, Leonardo, Huber (Farol), Enoch, Maiara, Fernando, Bruna, Vanessa, pelo convivio e amizade e Tio Chico pela amizade e pelos ensinamentos valiosos do EndNote

Aos amigos Antonio Humberto Minervino e carolina Cabral Araujo pela amizade, conversas, desabafos, alegria, companheiros de viagem, churrascos e videokês, sem vocês a pós sería desanimada em sem graça. obrigada por tudo.

A amiga Fernanda cavallini cyrillo, sem palavras para descrever o que você representou e representa para mim, obrigada por fazer parte de tudo isso, e obrigada pela ajuda com as cabras, nas colheitas e processamento das amostras e pela companhía nas viagens e no laboratório

A todas as cabras, em especial as meninas das baias 6 e 7 e a Rose que além se servirem de modelos fornecendo as amostras para esse estudo, me despertaram o amor pela espécie e principalmente me divertíram e cativaram muito

A querida amiga Rosangela Melatto, por me trazer tranquilidade em momentos dificeis para iniciar esse doutorado, pelo carinho, pelas orações e principalmente pela amizade

Ao amigo C. R. Minozzi pela elaboração da epigrafe desse trabalho

Aos amigos da familía salesiana sta Teresinha, pelo apoío espiritual, pelo carinho e principalmente pelas orações para que tudo desse certo.

As minhas avós, tios e primos que sempre torceram por minha formação

A amizade de Aline c. Oliveira, por estar presente nos principais momentos da minha vida e de Thaiana Lopes Ribeiro pelo apoí incondicional.

A todos que direta ou indiretamente participaram e contribuiram para a realização desse trabalho, Meus sinceros agradecimentos 


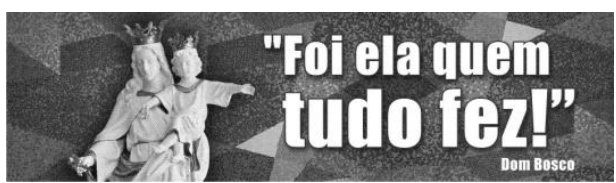




\section{RESUMO}

RAIMONDO, R. F. S Proteinograma da secreção láctea de cabras. [Goat milk proteinogram]. 2011. 148 f. Tese (Doutorado em Ciências) - Faculdade de Medicina Veterinária e Zootecnia, Universidade de São Paulo, São Paulo.

O objetivo do presente estudo foi estabelecer os valores de referência do proteinograma de soro lácteo por meio da técnica de eletroforese SDS-PAGE para a lactação plena e avaliar os efeitos do processo de secagem da glândula mamária, fase colostral e primeiro mês de lactação, fase de lactação, número de lactações, isolamento bacteriano e infecção pelo VCAE nas proteínas da secreção láctea de cabras da raça Saanen. Foram analisadas, entre 2007 e 2010, 545 amostras de leite provenientes de 185 cabras em diversas fases da lactação. Durante a lactação plena, baseado nos resultados dos intervalos de confiança, foram determinados os seguintes valores de referência: proteína total entre 2.940,0 e $3.050 \mathrm{mg} / \mathrm{dL}$; proteína do soro lácteo entre 903,0 e 973,0 mg/dL; lactoferrina entre 68,0 e $77,0 \mathrm{mg} / \mathrm{dL}$; albumina entre 88,0 e 97,0 mg/dL; imunoglobulina cadeia pesada entre 93,3 e 103,0 $\mathrm{mg} / \mathrm{dL}$; imunoglobulina cadeia leve entre 132,7 e 146,0 mg/dL; $\beta$-lactoglobulina entre 299,0 e $329,0 \mathrm{mg} / \mathrm{dL}$ e $\alpha$-lactoalbumina entre 213,0 e $229,5 \mathrm{mg} / \mathrm{dL}$. Os valores absolutos de proteína total, proteína do soro e frações protéicas aumentam durante a secagem da glândula. Antes da secagem predominavam as frações de $\beta$ - Lg e $\alpha$ La, a partir do $3^{\circ}$ dia, ocorre o surgimento das novas frações e a alteração do perfil protéico sem que haja o predomínio de nenhuma fração. A fase colostral, primeiras 24 horas de lactação, determinam as maiores concentrações de proteína total, proteína do soro e frações protéicas que diminuem após as primeiras 12 horas de lactação estabilizando após o $5^{\circ}$ dia. No colostro as imunoglobulinas são predominantes, e após o período de transição do colostro para o leite as frações $\beta$ Lg e $\alpha$-La são predominantes. Nos primeiros 15 dias de lactação, devido à influência da fase colostral, observa-se que as concentrações de proteína total e proteína do soro lácteo são maiores. A partir desse momento permanecem estáveis voltando a aumentar no final da lactação. As frações protéicas do soro de leite (lactoferrina, albumina sérica, imunoglobulina de cadeia pesada, imunoglobulina de cadeia leve, $\beta$-Lg e $\alpha$-La) também são máximas nos primeiros 15 dias de lactação e diminuem ao longo do período. A concentração de proteína do soro e suas frações em cabras 
primíparas foi menor quando comparadas com cabras pluríparas. $O$ isolamento bacteriano não influencia as concentrações de proteína total do leite e proteína do soro lácteo de cabras, contudo a concentração de lactoferrina é maior e as concentrações de $\beta$ - $\mathrm{Lg}$ e $\alpha$-La são menores em amostras com isolamento bacteriano. O CAEV não influencia as concentrações de proteína total do leite e proteína do soro lácteo de cabras, contudo a concentração de lactoferrina é maior e a concentração de e $\alpha$-La é menor em cabras sororeagentes positivas ao VCAE.

Palavras-chave:

Cabra. Proteína do soro de leite. Eletroforese SDS-PAGE. Artrite e encefalite caprina. Fase de lactação. 


\begin{abstract}
RAIMONDO, R. F. S. Goat milk proteinogram [Proteinograma da secreção láctea de cabras]. 2011. 148 f. Tese (Doutorado em Ciências) - Faculdade de Medicina Veterinária e Zootecnia, Universidade de São Paulo, São Paulo
\end{abstract}

The aim of this study was to establish reference values of the whey protein through the technique of SDS-PAGE for the full lactation and to evaluate the effects of the dry period of the mammary gland, colostral phase and first month of lactation, lactation, lactation number, bacterial isolation and VCAE infection in proteins of milk secretion in Saanen goats. Were analyzed between 2007 and 2010, 545 milk samples from 185 goats at different stages of lactation. During full lactation, based on the results of the confidence intervals were determined the following reference values: total protein between 2,940.0 and 3,050 mg / dL; whey protein between 903.0 and $973.0 \mathrm{mg} / \mathrm{dL}$; lactoferrin between 68.0 and $77.0 \mathrm{mg} / \mathrm{dL}$, serum albumin between 88.0 and $97.0 \mathrm{mg}$ $/ \mathrm{dL}$, immunoglobulin heavy chain between 93.3 and $103.0 \mathrm{mg} / \mathrm{dL}$, immunoglobulin light chain between 132.7 and 146, 0 mg / dL, $\beta$-lactoglobulin between 299.0 and $329.0 \mathrm{mg} / \mathrm{dL}$ and $\alpha$-lactalbumin between 213.0 and $229.5 \mathrm{mg} / \mathrm{dL}$. The absolute values of total protein, whey protein and protein fractions increase during the dry period. Prevailed prior to dry period the fractions of $\beta$ - $L g$ and $\alpha$-La from the 3rd day, occurs the emergence of new fractions and protein profile changes without the predominance of any fraction The colostral phase, the first 24 hours of lactation, determine the highest concentrations of total protein, whey protein and protein fractions that decrease after the first 12 hours of lactation stabilized after the 5 th day. Immunoglobulin in colostrum is prevalent, and after the period of transition from colostrum to milk fractions $\beta-\mathrm{Lg}$ and $\alpha$-La are predominant. In the first 15 days of lactation, due to the influence of colostral phase, it is observed that the concentrations of total protein and whey protein are higher. From then remain stable before rising again in late lactation. The protein fractions of whey (lactoferrin, serum albumin, immunoglobulin heavy chain, immunoglobulin light chain, $\beta$-Lg and $\alpha$-La) are also maximal in the first 15 days of lactation and decrease during the period. The concentration of whey protein and protein fractions in heifers are smaller when compared with multiparous goats. Bacteria isolation does not influence the concentrations of total protein from milk and whey protein of goats, but the 
concentration of lactoferrin is increased and the concentrations of $\beta-\mathrm{Lg}$ and $\alpha-\mathrm{La}$ is smaller in samples with bacterial isolation. The CAEV does not influence the concentrations of total protein and whey protein in goat, but the concentration of lactoferrin is higher and concentration of $\alpha$-La is less in goat positive by the CAEV.

Key words:

Goat. Whey protein. Electrophoresis SDS-PAGE. Caprine arthritis-encephalitis. Lactation phase. 


\section{LISTA DE QUADRO}

Quadro 1- Concentrações de proteína total e proteína do soro lácteo no início da lactação de acordo com a literatura compulsada.............. 41 


\section{LISTA DE TABELAS}

Tabela 1 - Constituição dos grupos amostrais para avaliar o proteinograma da secreção láctea de caprinos durante o processo de secagem na glândula mamária

Tabela 2 - Constituição dos grupos amostrais para avaliar o proteinograma da secreção láctea de caprinos durante o primeiro mês de lactação.

Tabela 3 - Média, desvio padrão (DP), intervalo de confiança (IC 95\%) das da proteína total da secreção láctea, da proteína do soro lácteo e das frações protéicas (lactoferrina; albumina; imunoglobulinas de cadeia pesada; imunoglobulinas de cadeia leve; $\beta$-lactoglobulina e $\alpha$-lactoalbumina) durante 0 processo de secagem da glândula mamária de cabras Saanen - São Paulo - 2007 a 2010.

Tabela 4 - Média, desvio padrão (DP), intervalo de confiança (IC 95\%) das frações protéicas (proteínas com peso molecular entre $100-290$ kDa; proteínas com peso molecular entre 30 - 44 kDa e proteínas com peso molecular entre $10-12 \mathrm{kDa}$ ) durante o processo de secagem da glândula mamária de cabras Saanen - São Paulo 2007 a 2010

Tabela 5 - Média, desvio padrão (DP), intervalo de confiança (IC 95\%) da proteína total da secreção láctea, da proteína do soro lácteo e das frações protéicas (fração de 132 a $244 \mathrm{kDa}$, lactoferrina; albumina; imunoglobulinas de cadeia pesada; fração de 30 a 50 $\mathrm{kDa}$ imunoglobulinas de cadeia leve; $\beta$-lactoglobulina; $\alpha$ lactoalbumina) durante o primeiro mês de lactação de cabras da raça Saanen - São Paulo - 2007 a 2010

Tabela 6 - Média, desvio padrão, intervalo de confiança (95\%) das frações protéicas (lactoferrina; albumina; imunoglobulinas de cadeia pesada e cadeia leve; $\beta$-lactoglobulina; $\alpha$-lactoalbumina) do soro de leite de cabras Saanen durante a lactação plena - São Paulo 2007 a 2010

Tabela 7 - Média, desvio padrão (DP), intervalo de confiança (IC 95\%) da proteína total, proteína do soro lácteo e das frações protéicas (lactoferrina; albumina; imunoglobulinas de cadeia pesada; imunoglobulinas de cadeia leve; $\beta$-lactoglobulina; $\alpha$ lactoalbumina) durante a lactação de cabras Saanen - São Paulo -2007 a 2010

Tabela 8 - Média, desvio padrão (DP), intervalo de confiança (IC 95\%) da proteína total, proteína do soro lácteo e das frações protéicas (lactoferrina; albumina; imunoglobulinas de cadeia pesada; imunoglobulinas de cadeia leve; $\beta$-lactoglobulina; $\alpha$ lactoalbumina) conforme o número de lactações de cabras Saanen - São Paulo - 2007 a 2010 
Tabela 9 - Descrição do gênero e da espécie de bactérias isoladas no leite de cabras - São Paulo - 2007 a 2010

Tabela 10 - Média, desvio padrão (DP), intervalo de confiança (IC 95\%) da proteína total, proteína do soro lácteo e das frações protéicas (lactoferrina; albumina; imunoglobulinas de cadeia pesada, imunoglobulina cadeia leve, $\beta$-lactoglobulina e $\alpha$-lactoalbumina) no leite de cabras Saanen positivas no exame bacteriológico e no leite de cabras negativas no exame bacteriológico - São Paulo - 2007 a 2010

Tabela 11 - Média, desvio padrão (DP) e intervalo de confiança (95\%) da proteína total, proteína do soro e das frações protéicas (lactoferrina; albumina; imunoglobulinas de cadeia pesada; imunoglobulinas de cadeia leve; $\beta$-lactoglobulina; $\alpha$ lactoalbumina) no leite de cabras Saanen sororeagentes positivas ao antígeno do vírus da Artrite e encefalite caprina e cabras controle negativo - São Paulo - 2007 a 2010. 


\section{LISTA DE GRÁFICOS}

Gráfico 1 - Comparação dos valores de proteína do soro lácteo determinados pelo método de Biureto e método de Kjeldahl. São Paulo 2008.

Gráfico 2- Curva padrão para determinação de proteína total do soro lácteo pelo método de Biureto. São Paulo 2008.

Gráfico 3 - Avaliação da influência do processo de secagem nos teores de proteína total e proteína do soro lácteo de cabras Saanen - São Paulo - 2007 a 2010.

Gráfico 4 - Eletroforetograma das proteínas do soro lácteo de cabras Saanen durante o processo de secagem da glândula mamária, obtido através de eletroforese em gel de poliacrilamida (12\%) (SDS-PAGE) - São Paulo - 2007 a 2010

Gráfico 5 - Concentração (\%) das proteínas fracionadas do soro lácteo de cabras Saanen em relação à proteina do soro durante o processo de secagem da glândula mamária obtida através da técnica de eletroforese em gel de poliacrilamida (12\%) (SDSPAGE) - São Paulo - 2007 a 2010.

Gráfico 6 - Avaliação da influência do processo de secagem da glândula mamária nas frações protéicas do soro lácteo de cabras Saanen - São Paulo - 2007 a 2010.

Gráfico 7 - Avaliação da influência do processo de secagem da glândula mamária nas frações protéicas do soro lácteo de cabras Saanen - São Paulo - 2007 a 2010

Gráfico 8 - Avaliação da influência da fase colostral e do primeiro mês de lactação nos teores de proteína total e proteína do soro lácteo de cabras Saanen - São Paulo - 2007 a 2010.

Gráfico 9 - Eletroforetograma das proteínas do soro lácteo de cabras Saanen durante a fase colostral e o primeiro mês de lactação, obtido através de eletroforese em gel de poliacrilamida (12\%) (SDS-PAGE) - São Paulo - 2007 a 2010...

Gráfico 10 - Concentração (\%) das proteínas fracionadas do soro lácteo de cabras Saanen em relação à proteína do soro durante o primeiro mês de lactação obtida através da técnica de eletroforese em gel de poliacrilamida (12\%) (SDS-PAGE) - São Paulo - 2007 a 2010.

Gráfico 11 - Avaliação da influência da fase colostral e do primeiro mês de lactação nas frações protéicas do soro lácteo de cabras Saanen - São Paulo - 2007 a 2010. 
Gráfico 12 - Eletroforetograma das proteínas do soro lácteo de cabras Saanen durante a lactação plena, obtido através de eletroforese em gel de poliacrilamida (12\%) (SDS-PAGE) - São Paulo - 2007 a 2010 .

Gráfico 13 - Concentração (\%) das proteínas fracionadas do soro lácteo de cabras Saanen em relação à proteína do soro durante lactação plena, obtida através da técnica de eletroforese em gel de poliacrilamida (12\%) (SDS-PAGE) - São Paulo - 2007 a 2010......

Gráfico 14 - Avaliação da influência da fase de lactação nos teores de proteína total do leite e proteína do soro lácteo de cabras Saanen - São Paulo - 2007 a 2010.

Gráfico 15 - Avaliação da influência da fase de lactação nas frações protéicas do soro lácteo do leite de cabras Saanen - São Paulo 2007 a 2010.

Gráfico 16 - Avaliação da influência do número de lactações nos teores de proteína total do leite e proteína do soro lácteo de cabras Saanen - São Paulo - 2007 a 2010.

Gráfico 17 - Avaliação da influência do número de lactações nas frações protéicas do soro lácteo do leite de cabras Saanen - São Paulo 2007 a 2010

Gráfico 18 - Avaliação da influencia do isolamento bacteriano nos teores de proteína total do leite e proteína do soro lácteo de cabras Saanen - São Paulo - 2007 a 2010.

Gráfico 19 - Avaliação da influência do isolamento bacteriano nas frações protéicas do soro lácteo do leite de cabras Saanen - São Paulo 2007 a 2010

Gráfico 20 - Avaliação da influência do vírus da Artrite e encefalite caprina (CAE) nos teores de proteína total do leite e proteína do soro lácteo de cabras Saanen - São Paulo - 2007 a 2010.

Gráfico 21 - Concentração (\%) das proteínas fracionadas em relação à proteína total do soro lácteo de cabras Saanen sororeagentes positivas ao antígeno do vírus da Artrite e encefalite caprina e cabras controle negativo ao antígeno do vírus da Artrite e encefalite caprina obtida através da técnica de eletroforese em gel de poliacrilamida (12\%) (SDS-PAGE) - São Paulo - 2007 a 2010

Gráfico 22 - Avaliação da influência do vírus da artrite e encefalite caprina (CAE) nas frações protéicas do soro lácteo do leite de cabras Saanen - São Paulo - 2007 a 2010. 


\section{LISTA DE ABREVIATURAS}

CAE Artrite e encefalite caprina

CCS Contagem de células somáticas

dL Decilitro

DP Desvio padrão da média

ELISA Enzyme-Linked ImmunoSorbent Assay (Imunoensaio de enzima de anticorpo)

FMVZ-USP Faculdade de Medicina Veterinária e Zootecnia da Universidade de São Paulo

IC Intervalo de confiança

$\lg (\mathrm{s}) \quad$ Imunoglobulina(s)

IgA Imunoglobulina classe A

Ig $G \quad$ Imunoglobulina classe $G$

IgG, Imunoglobulina classe $G$ sub-classe 1

$\lg \mathrm{G}_{2}, \quad$ Imunoglobulina classe $\mathrm{G}$ sub-classe 2

IgM Imunoglobulina classe M

$\mathrm{kDa} \quad$ Quilodalton

kg Quilograma

L Litro

mg Miligrama

PAGE Polyacrylamide gel electrophoresis (eletroforese em gel de poliacrilamida)

$\mathrm{pH} \quad$ Potencial hidrogeniônico

Psoro Proteína do soro lácteo

Ptotal Proteína total

SDS Sodium dodecyl sulfate (dodecil-sulfato de sódio)

SDS-PAGE Sodium dodecyl sulfate polyacrylamide gel electrophoresis (gel de poliacrilamida com dodecil sulfato de sódio)

VCAE Vírus da Artrite-encefalite caprina

a-La $\quad \alpha$-lactoalbumina

$\beta$-Lg $\quad \beta$-lactoglobulina 
LISTA DE SÍMBOLOS

$\begin{array}{ll}\alpha & \text { Alfa } \\ \beta & \text { Beta } \\ k & \text { kappa } \\ \pm & \text { Mais ou menos } \\ < & \text { Menor } \\ \leq & \text { Menor ou igual } \\ \% & \text { Porcentagem }\end{array}$




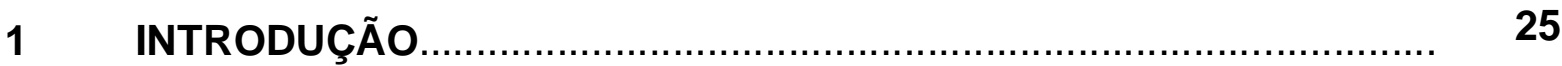

2 REVISÃO DE LITERATURA ................................................ 28

2.1 Avaliação da influência do processo de secagem da glândula mamária no proteinograma da secreção láctea de cabras...

2.2 Avaliação da influência do período colostral e do primeiro mês de lactação no proteinograma da secreção láctea de cabras.

2.3 Proteinograma do leite de cabras durante a lactação plena: valores de referência, influência da fase de lactação e do número de lactações.

2.4 Influência do isolamento bacteriano no proteinograma do leite de cabras.

2.5 Influência do vírus da artrite-encefalite caprina no Proteinograma do leite de cabras durante a lactação plena: valores de referência, influência da fase de lactação e do número de lactações proteinograma do leite de cabras.

3 MATERIAIS E MÉTODOS

3.1 Avaliação da influência do processo de secagem da glândula mamária no proteinograma da secreção láctea de cabras..

3.2 Avaliação da influência da fase colostral e do primeiro mês de lactação no proteinograma da secreção láctea de cabras.

3.3 Proteinograma do leite de cabras durante a lactação plena: valores de referência, influência da fase de lactação e do número de lactações.

3.4 Avaliação da influência do isolamento bacteriano no proteinograma do leite de cabras.

3.5 Avaliação da influência da infecção do Vírus da Artite-encefalite caprina (CAE) no proteinograma do leite de cabras

3.6 Colheita das amostras.

3.7 Análises

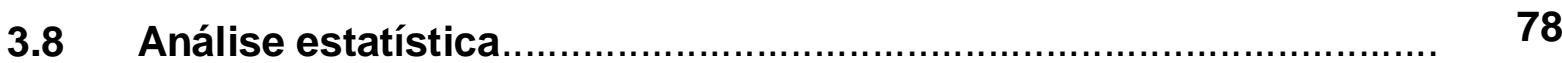

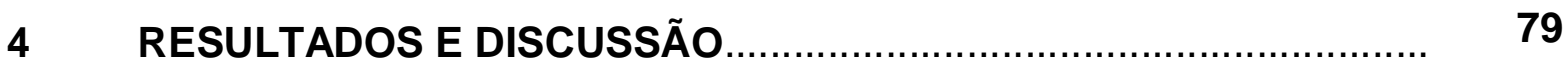


4.1 Avaliação da influência do processo de secagem da glândula mamária no proteinograma da secreção láctea de cabras.

4.2 Avaliação da influência da fase colostral e do primeiro mês de lactação no proteinograma da secreção láctea de cabras.

4.3 Proteinograma do leite de cabras durante a lactação plena.

4.3.1 Valores de referência do proteinograma do leite de cabras

4.3.2 Influência da fase de lactação no proteinograma do leite de cabras......

4.3.3 Resultados da influência do número de lactações no proteinograma do leite de cabras.

4.4 Avaliação da influência do isolamento bacteriano no proteinograma do leite de cabras

4.5 Avaliação da influência da infecção do Vírus da Artite-encefalite caprina (CAE) no proteinograma do leite de cabras

5 CONCLUSÕES

REFERENCIAS 
Introdução

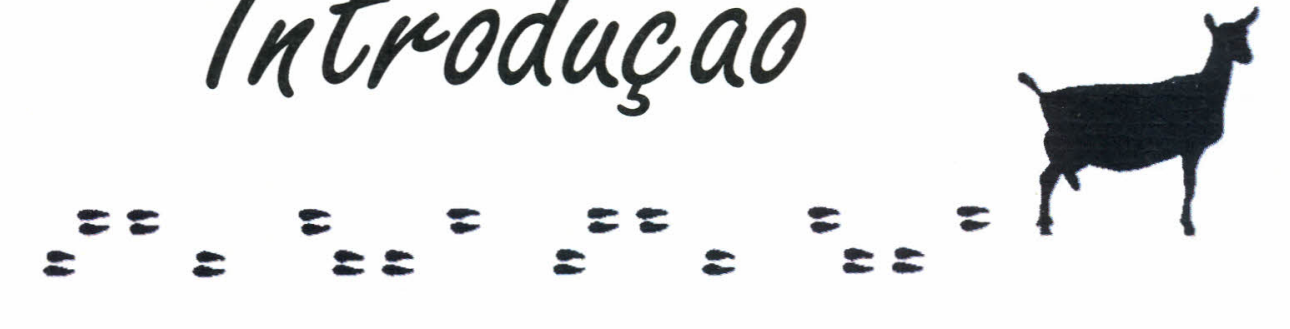




\section{INTRODUÇÃO}

A criação de caprinos no Brasil, com início entre os séculos $X V I$ e XVIII, segundo o último censo agropecuário realizado em 2006 detém 11.460 .735 animais, deste total mais de $90 \%$ localizados na região nordeste (IBGE, 2006). Segundo a FAO (2006), o Brasil possui o décimo quinto rebanho mundial, sendo que 42,05\% do rebanho são representados por cabras leiteiras colocando o País como o oitavo rebanho de caprinos leiteiros do mundo. Apesar da maior parte do rebanho estar concentrada na região Nordeste, a produção de leite do Sudeste igual a 12.000 litros/dia, representa $54.6 \%$ de todo o leite de cabra que é produzido no País.

A caprinocultura leiteira vem crescendo consideravelmente na última década, principalmente pelo aumento da procura e do consumo do leite e seus derivados, sejam pelas suas características nutricionais, assim como no uso na alimentação de lactentes e crianças que apresentam a intolerância ao leite bovino. Contudo, apesar de existirem na literatura trabalhos relacionados ao leite dessa espécie, os resultados são escassos, pouco representativos, parciais ou obtidos de pequeno número de animais, dessa maneira o conhecimento da composição e das propriedades do leite caprino, e sua variabilidade normal é de suma importância.

A constituição protéica do leite, até recentemente não era considerada importante no diagnóstico das doenças da glândula mamária, porém os resultados obtidos por Sant'ana (2004), evidenciaram que a determinação do teor de proteína total do leite e seu fracionamento podem ser utilizado para o diagnóstico das mamites, pois segundo a autora nesses casos patológicos o aumento dos teores de proteína total com diminuição dos teores de caseína e aumento dos teores de proteínas de origem plasmática no soro lácteo representa sintoma de alteração da glândula mamária, principalmente alterações de permeabilidade.

A proteína do leite, assim como os outros contituíntes, são influenciados por diversos fatores entre eles: fase de lactação, número de lactações, raça dos animais, celularidade do leite além da inflamação da glândula mamária ocasionada pelas mamites. $\mathrm{Na}$ espécie caprina, além das mamites, outra enfermidade que pode acometer a glândula mamária dos caprinos é a artrite encefalite caprina (CAE), uma doença infecciosa causa pelo retrovírus pertencente à subfamília Lentivirinae que 
acomete caprinos de todas as raças e idades. Na glândula mamária de cabras infectadas descreveu-se o endurecimento gradativo com a presença de vários nódulos de consistência dura, que confluem para determinar um endurecimento difuso do parênquima mamário, resultando em assimetria das metades do úbere (LARA, 2002).

A importância da avaliação da proteína do soro lácteo e de suas frações protéicas no auxílio diagnóstico das afecções da glândula mamária é conhecida em bovinos, contudo há deficiência em estudos na espécie caprina, assim como na avaliação das influências fisiológicas e patológicas nas proteínas da secreção láctea dessa espécie. Diante de tais fatos e da crescente importância da caprinocultura no Brasil, a presente pesquisa objetivou o estudo do proteinograma da secreção láctea de cabras através da técnica de eletroforese SDS-PAGE determinando os valores de referência para a lactação plena e avaliando as seguintes influências: processo de secagem da glândula mamária, fase colostral e primeiro mês de lactação, fase de lactação, número de lactações, isolamento bacteriano e infecção pelo CAEV. 
Revisão de literatura

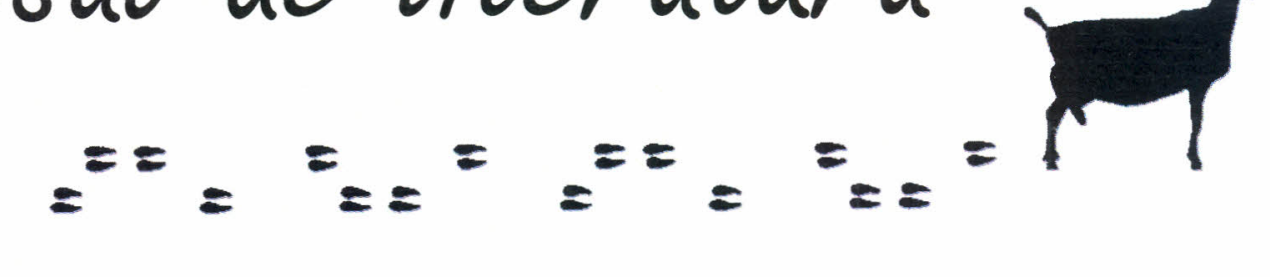




\section{REVISÃO DE LITERATURA}

Proteínas são as macromoléculas mais abundantes nas células vivas, apresentando-se em diversos tipos, desde peptídeos de tamanho relativamente pequeno até enormes polímeros. Proteínas exibem diversas funções biológicas e são responsáveis pela expressão genética (NELSON; COX, 2000).

São classificadas de acordo com suas formas e composição, podendo apresentar: estrutura primária, que são aminoácidos estruturais com cadeia polipeptídica simples; estrutura secundária, as quais apresentam cadeia de estrutura helicoidal; estrutura terciária, dobramento da hélice em diferentes formas (tridimensional), como globular ou linear e finalmente estrutura quaternária que são combinações de dois ou mais monômeros. Estas são classificadas de acordo com sua composição química podendo ser: proteínas simples, contendo elementos básicos de aminoácidos, carbono, hidrogênio, oxigênio, nitrogênio e enxofre, ou proteínas conjugadas, essas apresentam elementos, grupos protéicos, ou outros componentes (KANEKO; HARVEY; BRUSS, 2008)

A proteína total do leite é formada por proteínas sintetizadas na glândula mamária e por proteínas provenientes do sangue. Aproximadamente $90 \%$ da proteína total do leite são compostas por caseína e proteínas do soro lácteo, que são sintetizadas nas células alveolares, a partir de aminoácidos essenciais do sangue e aminoácidos não essenciais produzidos pela própria célula secretora. Os outros $10 \%$ de proteína total, albumina e globulinas, não são sintetizados na glândula mamária e são transportadas para o leite via sangue até entrarem no lúmen alveolar (SCHALM; CARROLL; JAIN, 1971; FONSECA; SANTOS, 2000).

O soro lácteo é a porção aquosa do leite que se separa do coágulo durante a fabricação convencional de queijos ou da caseína, contém uma mistura de várias proteínas, $\beta$-lactoglobulina, $\alpha$-lactoalbumina, lactoferrina, imunoglobulinas, albumina sérica. São na sua maioria proteínas globulares que conferem muitas das suas propriedades funcionais. Algumas das suas funções biológicas são conhecidas, outras emergem, porém outras ainda não foram descobertas.

$\beta$-lactoglobulina $(\boldsymbol{\beta}-\mathbf{L g})$ é a principal proteína do soro lácteo secretada no leite de ruminantes, representado aproximadamente $50 \%$ da proteína do soro e $10 \%$ da proteína total do leite (SAWYER, 2003). Isolada pela primeira vez por Palmer 
(1934) está presente no leite de monogástricos como porca, égua, cadela, gata e marsupiais e é ausente no leite de humanos, lagomorfos e roedores. É uma proteína globular com parede de estrutura tridimensional, composta por 162 resíduos de aminoácidos, com um peso molecular igual a 18,27 kDa (FARRELL et al., 2004), primeiramente seqüenciada por Braunitzer et al. ${ }^{1}$ (1972 apud SAWYER, 2003, p. 319) e genotipada por Alexander et al. (1993) no leite bovino e no leite de cabras por Yahyaoui et al. (2000).

Sua estrutura de aminoácidos possui um valor nutricional, porém sua função biológica ainda não está bem elucidada, acredita-se em um papel no metabolismo do fosfato na glândula mamária, no transporte de vitamina $A$ e de outras moléculas como ácidos graxos no trato gastrointestinal de neonatos (SAWYER, 2003). De acordo com Formaggione et al. (1999) 12 variantes genéticas da $\beta$-Lg foram identificadas em bovinos: A a J, W e Dr, e esse polimorfismo vem sendo estudado, pois está relacionado com alterações nas características físico-químicas da micela de caseína, afetando as propriedades tecnológicas do leite (ROBITAILLE, 1995). Kumar, Rout e Roy (2006) observaram diferença na produção de leite de cabras indianas relacionado ao genótipo da $\beta$-Lg. De acordo com Botaro et al.(2007) as características físico-químicas do leite de vacas Holandesas e Girolandas não sofrem influência do polimorfismo da $\beta$-Lg.

$\boldsymbol{\alpha}$-lactoalbumina ( $\alpha$-La) é a segunda proteína mais abundante no soro lácteo e foi isolada a mais de 60 anos atrás. Esta proteína teve um significante papel no desenvolvimento dos métodos de estudos das propriedades físico-químicas das proteínas e atualmente é utilizada como modelo de estudos. Após três décadas de estudos foi descoberto que a função da $\alpha$-La não era meramente nutricional, mas sim uma componente chave na síntese de lactose. A $\alpha$-La juntamente com $\beta 1,4$ galactosiltransferase formam o complexo lactose-sintetase no aparelho de Golgi das células mamárias epiteliais regulando a síntese de lactose (FARRELL et al., 2004; BLECK et al., 2009). A lactose formada pela ligação glicose e galactose se acumula no complexo de Golgi ocasionando a entrada de água neste aparato, sendo um importante processo para a formação da fase aquosa do leite. O complexo enzima lactose-sintetase é responsável pela regulação osmótica do volume de leite e as

\footnotetext{
${ }^{1}$ BRAUNITZER, G.; CHEN, R.; SCHRANK, B.; STANGL, A. Die sequenzanalyse des $\beta$-lactoglobulins. Hoppe-Seyler's Zeitung für Phisiologie und Chemie, v. 353, p. 832-834, 1972
} 
variações genéticas da $\alpha$-La podem ser importantes indicadores do potencial genético de produção. (BREW, 2003; ZHANG; BREW, 2003)

A $\alpha$-La é encontrada no leite, porque parte é liberada do complexo sintase-lactose durante a lactação normal e é transportada com outros componentes do leite em vesículas dentro da célula secretora do epitélio mamário e, em seguida para dentro do lúmen dos alvéolos (JENNESS, 1974). A massa molecular total é de 14,18 kDa, formada por cadeia única de 123 resíduos de aminoácidos cuja sequência na espécie caprina e bovina é $94 \%$ idêntica e é a única proteína do soro lácteo presente no leite de todas as subdivisões mamíferas (BREW, 2003; ZHANG; BREW, 2003). Sua concentração só é superada pela $\beta$-Lg.

Lactoferrina é uma glicoproteína ligada ao ferro que foi identificada no leite bovino em 1939, mas somente isolada na década de 1960. É relacionada com a transferrina plasmática que também é encontrada no leite em pequena quantidade, porém são moléculas distintas provenientes de genes diferentes e se comportam diferentemente em sistemas biológicos. A afinidade pelo ferro é maior na lactoferrina quando comparada a transferrina. Essas proteínas podem ser produzidas por todos os mamíferos, contudo as suas concentrações variam de acordo com as espécies (KORHONEN; MARNILA, 2003).

A lactoferrina é produzida na glândula mamária pelas células epiteliais, mas também por outras glândulas exócrinas podendo ser encontradas na saliva, lágrima, suor e sêmen. No plasma é derivado predominantemente dos neutrófilos liberado de grânulos secundários durante a inflamação. É uma proteína de cadeia única com a massa molecular em torno de $80 \mathrm{kDa}$ (LÖNNERDAL, 2003), formada por sequência de 708 aminoácidos (FARRELL et al., 2004). Está presente em grandes concentrações no colostro humano e bovino e na secreção da glândula mamária não lactante, de humanos e bovinos suas concentrações aumentam. Também está presente no leite de éguas, porcas, ratas e não é encontrada no leite de coelhas, cadelas (KORHONEN; MARNILA, 2003). Foi isolada no leite de cabras, ovelhas, camelo e alpaca por Conesa et al. (2008).

No leite com mamite as concentrações de lactoferrina multiplicam devido às grandes quantias de leucócitos ativados liberados, dessa maneira ela desempenha um papel protetor na glândula mamária (KORHONEN; MARNILA, 2003). Diante de infecções e inflamações a lactoferrina atua como a primeira linha de proteção com ação bacteriostática, pela capacidade de seqüestrar o ferro livre que é um essencial 
nutriente para a bactéria, e também atividade antibacteriana pela habilidade em se ligar a membrana exterior de bactérias Gram-negativas causando a liberação rápida de lipopolisacárides e um aumento na permeabilidade da membrana. Além disso, a lactoferrina desempenha atividade antiviral contra vírus RNA e DNA (FARRELL et al., 2004)

Albumina sérica é a principal e mais abundante proteína sérica, presente em todos os tecidos e secreções do corpo, sintetizada no fígado, sua concentração no leite reflete a concentração no sangue. Desempenha como principais funções o transporte, metabolismo e distribuição de ligantes, entre eles, ácidos graxos, hormônios, bilirrubina, e íons, concede proteção contra radicais livres e manutenção da osmolaridade e pH sanguíneos (HAGGARTY, 2003; FARRELL et al., 2004). A albumina encontrada no leite é fisiologicamente e imunologicamente idêntica a do sangue (FARRELL et al., 2004) e a sua concentração está relacionada a diversos fatores fisiológicos e patológicos da glândula mamária quando ocorre aumento da permeabilidade vascular devido a processos inflamatórios (SCHALM; CARROLL; JAIN, 1971). Shamay et al. (2005) estudaram a síntese de albumina em tecidos não hepáticos, e observaram que a glândula mamária é capaz de sintetizar essa proteína principalmente em resposta as inflamações. Foi por muito anos assunto de interesse de pesquisas a fim de estabelecer sua estrutura e suas múltiplas funções, formada por cadeia única polipeptídica com 583 resíduos de aminoácidos com um peso molecular em torno de $66 \mathrm{kDa}$ representando cerca de 1,5\% da proteína total do leite (FARRELL et al., 2004).

Imunoglobulinas (Igs) também chamadas de anticorpos são encontradas no leite e no colostro de todas as espécies lactantes. Sua função biológica é conferir proteção imunológica a prole frente à patógenos e toxinas e proteger a glândula mamária contra infecções (MARNILA; KORHONEN, 2003). Diferente dos principais componentes presentes no leite, as imunoglobulinas não são sintetizadas na glândula mamária, são transportadas do sangue para o leite (MARNILA; KORHONEN, 2003).

As classes de imunoglobulinas presentes no leite de ruminantes são $\lg G, \lg M$ e IgA, sendo a $\lg G$ a principal classe, e a sua subclasse $\lg G_{1}$ corresponde em torno de $50-80 \%$ do total de imunoglobulinas (HURLEY, 2003; MARNILA; KORHONEN, 2003). O colostro bovino normalmente contém 50 a $150 \mathrm{mg} / \mathrm{ml}$ de imunoglobulinas, sendo que IgG compreende cerca de 85 a 95\%, IgM cerca de 7\% e IgA em torno de 
$5 \%$. A subclasse IgG 1 corresponde a 80 a $90 \%$ da classe IgG (LARSON; HEARY JR.; DEVERY, 1980).

A estrutura básica de todas as imunoglobulinas é similar, onde cada molécula é compostas por duas idênticas cadeias leves (peso molecular de cada cadeia em torno de $23 \mathrm{kDa}$ ) e duas idênticas cadeias pesadas (peso molecular de cada cadeia em torno de $53 \mathrm{kDa}$ ), perfazendo um peso molecular total em torno de $160 \mathrm{kDa}$. As cadeias leves são ligadas as cadeias pesadas por pontes dissulfeto, e as duas cadeias pesadas também são unidas por pontes dissulfeto resultando em uma molécula em forma de "Y". A classe lgG é formada por uma única molécula, a classe IgA pode ser um monômero ou um dímero com um peso molecular em torno de 380 $\mathrm{kDa}$, a classe IgM é a maior imunoglobulina formada por 5 moléculas com um peso molecular em torno de 900kDa (HURLEY; JUNIOR, 2003; MARNILA; KORHONEN, 2003).

As proteínas do leite devido as suas muitas propriedades únicas, e sua importância tecnológica, têm sido estudadas extensivamente e é provavelmente o melhor sistema de proteínas de alimentos caracterizadas. A investigação sobre as proteínas do leite tem início no século XIX com a avaliação das características físicoquímicas. Usando as técnicas disponíveis de 100 anos atrás, as proteínas do soro de leite foram geralmente consideradas similares as frações de proteínas do sangue que passavam diretamente para o leite e, por conseguinte, as proteínas do soro atraíram pouco esforço de pesquisa até 1930 (FOX, 2009) possivelmente com o avanço das técnicas de eletroforese.

O termo eletroforese foi criado por Michaelis, em 1909, para descrever a migração de colóides sob a influência de um campo elétrico, ou seja, representa a migração de íons submetidos à corrente elétrica baseado em um simples princípio: moléculas com carga negativa migram para o pólo positivo e moléculas com carga positiva migram para o pólo negativo (BRUNE; ALFENAS, 1998).

O uso da eletroforese como meio para a separação de proteínas foi inicialmente utilizado na década de 30 do século passado, quando Tiselius (1937) desenvolveu a técnica de eletroforese livre para separação de proteínas séricas. Nas décadas de 40 e 50 também no século passado deu-se um grande desenvolvimento na metodologia eletroforética com a introdução de suportes inertes no meio e do desenvolvimento da eletroforese de zona. Estudos preliminares de Smithies (1955) descreveram a capacidade de peneira dos géis de amido e sua 
porosidade, capacidade essa que anteriormente não ocorria nos suportes de papel. Este estudo inspirou Davis (1964) que desenvolveu uma nova técnica de eletroforese de zona utilizando como suporte um gel de poliacrilamida que havia sido testado anteriormente em 1959 em seu laboratório em um sistema descontínuo com géis de diferentes porosidades. Essas descobertas trouxeram grandes avanços, os géis deixam de ser simplesmente suportes e com sua capacidade de peneira devido à porosidade permite que a separação das moléculas ocorra não somente por carga, mas também por diferença tamanho.

No final da década de 60 no século passado Shapiro, Vinuela e Maizel (1967) descreveram a eletroforese em gel de poliacrilamida em presença do detergente aniônico dodecil sulfato de sódio (SDS) e indicaram que neste meio a separação é dependente do peso molecular. Weber e Osborn (1969) confirmaram a acerácea da técnica de eletroforese em gel de poliacrilamida com SDS e concluem que a facilidade com que o método pode ser aplicado, deve incentivar a sua ampla utilização.

Finalmente Laemmli (1970) descreve a técnica de eletroforese em gel de poliacrilamida na presença de SDS com proteínas desnaturadas em sistema descontínuo, a atual técnica de eletroforese SDS-PAGE que é a abreviatura do inglês de dodecil-sulfato de sódio (SDS) e de gel de poliacrilamida (PAGE). Desde então, a eletroforese tem sido universalmente adotada para a pesquisa de proteínas, desde a introdução da poliacrilamida como suporte. A técnica progrediu de separações baseadas apenas em massa e carga (PAGE) para aqueles com base no peso molecular (SDS-PAGE) ou ponto isoelétrico (STRANGE et al., 1992)

No sistema de eletroforese SDS-PAGE a proteína é desnaturada por aquecimento a $100^{\circ} \mathrm{C}$, na presença de 2-mercaptoetanol e do detergente SDS. O 2mercaptoetanol reduz as ligações dissulfídricas por ruptura, e os polipeptídios adquirem a carga negativa do SDS e a organização da cadeia peptídica na sua estrutura terciária é deteriorada. A cadeia peptídica providas de acentuada carga negativa migra com velocidade definida apenas por diferença de tamanho molecular. O sistema descontínuo utiliza dois géis de diferentes porosidades, um gel separador com porosidade menor e um gel empilhador com maior porosidade. (BRUNE; ALFENAS, 1998).

O uso da técnica de eletroforese em gel de poliacrilamida nas proteínas do soro lácteo foi inicialmente descrita por Hiller (1976) que descreveu que a técnica 
poderia ser recomendada, com adequada precisão para a mensuração das frações protéicas do soro lácteo. Basch et al. (1985) adaptaram a técnica descrita por Laemmli (1970) para o uso no leite e derivados e confirmam que a técnica de eletroforese SDS-PAGE um método eficaz para obter a relação de caseína, proteínas do soro de leite e em produtos lácteos assim como seu uso na detecção de adulteração de sólidos nesses produtos. Kato, Mori e Katoh (1989), confirmaram as referidas recomendações ao destacarem a importância da eletroforese em gel de poliacrilamida para o isolamento e identificação das proteínas e enzimas do leite, contribuindo para o esclarecimento da patogenia das mamites.

\subsection{Avaliação da influência do processo de secagem da glândula mamária no proteinograma da secreção láctea de cabras}

Período seco é o período que vai entre o final da lactação e o próximo parto, entre 45 e 60 dias, períodos maiores implicam maior tempo sem produzir, e períodos inferiores acarretam um desgaste excessivo da cabra, com prejuízo para as crias e, possivelmente, para a próxima lactação (RIBEIRO, 1998). As vantagens da adoção de um período seco estão relacionadas à saúde da glândula mamária, à produtividade e à saúde do animal, em geral, na lactação seguinte (DINGWELL; KELTON; LESLIE, 2003). A produção de leite depende da atividade e do número de células epiteliais mamárias (KNIGHT, 2000) que é determinado pelas taxas de apoptose e proliferação celular, que ocorrem durante a lactação, resultando em um volume considerável de células mamárias (CAPUCO et al., 2001).

Em bovinos o uso do período seco é de grande importância, sendo que a supressão desta fase leva a redução da produção leiteira na lactação seguinte (SWANSON, 1965). Entretanto, Salama (2005) verificou redução de $16 \%$ na produção de leite de cabras que não tiveram período seco e em cabras com um período seco de 27 e 56 dias um aumento de $15 \%$ e $4 \%$ respectivamente, na lactação subseqüente. $O$ autor relatou ainda que cabras sem período seco produziram colostro de menor qualidade com quantidade de $\mathrm{lgG}$, sólidos totais e proteínas menores quando comparadas às cabras submetidas a um período seco.

Caja, Salama e Such (2006) avaliaram a omissão do período seco em cabras e observaram efeitos negativos dessa omissão sobre a produção de leite. Os 
autores observaram que as crias das cabras que não foram secas tinham peso menor ao nascimento $(1,7 \mathrm{~kg})$ do que as crias de cabra com 27 dias de secagem $(2,2 \mathrm{~kg})$ e 56 dias de secagem $(2,1 \mathrm{~kg})$. O colostro de cabras não secas continha menos IgG (560 mg/dL) do que as com 27 dias de secagem (329 mg/dL) e 56 dias de secagem (424 mg/dL). Na lactação seguinte (210 dias), as cabras que não tiveram período seco produziram menos leite $(1,78 \mathrm{~L} /$ dia $)$ que as cabras com 27 dias de secagem $(2,51 \mathrm{~L} /$ dia) e 56 dias de secagem (2,24 L/dia). Apoptose e os índices de proliferação aumentaram de 0,51 e 2,09\%, em 65 dias antes do parto, para 1,75 e 7,12\% em 49 dias antes do parto ( $7^{\circ}$ dia de secagem), nas cabras que tiveram 56 dias de período seco. Segundo os autores omitir o período seco entre as lactações reduziu a qualidade do colostro e teve efeitos negativos sobre a produção de leite em cabras leiteiras.

O período de lactação em caprinos pode variar de 127 (JAITNER et al., 2006) a 316 dias (MACEDO et al., 2001). Após o pico de lactação, a produção de leite diminui até que cesse por completo. Paralelamente ocorre um processo de regressão do tecido mamário até o período de secagem, quando esse processo se acentua ocorre intensa apoptose das células epiteliais e a reabsorção do leite presente iniciando a substituição do tecido secretor por tecido conjuntivo, que passa a representar grande parte do tecido existente na glândula mamária durante 0 período seco (HOLST; HURLEY; NELSON, 1987; FRANDSON; WILKE; FAILS, 2005).

Boutinaud et al. (2003) relataram que, ao diminuir a frequência de ordenha das cabras, os alvéolos sofreram redução de diâmetro relacionada à diminuição do número de células secretórias. O subseqüente acúmulo de leite na cisterna leva à abertura das junções celulares e a um aumento da permeabilidade vascular. Segundo Fleet e Peaker (1978) em cabras ocorre redução de 57\% na produção logo no $2^{\circ}$ dia após a interrupção da ordenha e que no $3^{\circ}$ dia a quantidade secretada corresponde a $22 \%$ do volume ordenhado antes da interrupção da ordenha. Essa diminuição da secreção é acompanhada por queda no aporte de oxigênio, glicose e acetato para a glândula mamária, e a partir do $4^{\circ}$ dia a reabsorção de leite se inicia e a taxa de secreção é considerada nula. $O$ volume do parênquima do úbere de cabras que deixam de ser ordenhadas diminui $44 \%$ em duas semanas (FOWLER; KNIGHT; FOSTER, 1991). 
Em conjunto com as mudanças estruturais da glândula mamária que ocorrem no período seco há também diversas mudanças na composição da secreção láctea com a diminuição da taxa de secreção. De acordo com Linzel e Peaker (1971), durante o período seco de cabras não gravídicas os ductos mamários tornam-se permeáveis à lactose e íons, ao contrário do que ocorre no período de lactação, quando os ductos são impermeáveis à passagem desses componentes do leite.

As características físico-químicas da secreção láctea de cabras são influenciadas pelo período seco a partir do terceiro ou quarto dia, quando são observados um aumento do $\mathrm{pH}$, das proteínas e dos íons sódio e cloro associados à diminuição dos teores de potássio, lactose e citrato (FLEET; PEAKER, 1978).

Ziv e Gordin (1973) mensuraram os teores de proteína total na secreção láctea de fêmeas bovinas produzida no 14ํ dia após o início da secagem e encontraram valor médio igual a $10.000 \mathrm{mg} / \mathrm{dL}$, que aumentou para $15.000 \mathrm{mg} / \mathrm{dL}$ no $28^{\circ}$ dia, 25.000 no $38^{\circ}$ dia. Hurley (1989) também avaliou a proteína total durante a involução da glândula mamária de vacas, com valores de $4.500 \mathrm{mg} / \mathrm{dL}$ antes da secagem, $4.800 \mathrm{mg} / \mathrm{dL}$ no $1^{\circ}=\mathrm{dia}, 6.900 \mathrm{mg} / \mathrm{dL}$ no $3^{\circ} \mathrm{dia}, 9.300 \mathrm{mg} / \mathrm{dL}$ no $7^{\circ} \stackrel{0}{\mathrm{dia}}$, $10.300 \mathrm{mg} / \mathrm{dL}$ no $11^{\circ} \mathrm{dia}, 8.500$ no $18^{\circ}$ dia chegando a $18.800 \mathrm{mg} / \mathrm{dL}$ no $30^{\circ} \mathrm{dia}$.

As concentrações das proteínas séricas, normalmente presentes no soro lácteo, variam pouco nos primeiros dias de secagem, entretanto, após sete dias é possível observar um aumento dessas proteínas, refletindo, um aumento da permeabilidade das células secretórias à passagem das proteínas séricas. Porém, o aumento de proteínas não chega aos níveis alcançados em processos inflamatórios, indicando que deva existir algum tipo de controle por parte da glândula mamária sobre a permeabilidade das junções celulares (SMITH; TODHUNTER, 1982).

Mudanças na composição da secreção láctea durante a involução incluem diminuição nas proteínas lácteas específicas, como a caseína, $\alpha$-La e $\beta$-Lg (ASLAM et al., 1994) e o aumento da permeabilidade do epitélio mamário que ocorre nessa fase resulta no início da transferência de proteínas séricas, como a albumina e imunoglobulinas para a glândula (HURLEY, 1989).

A lactoferrina é considerada a primeira linha de defesa contra os patógenos da mamite e que desempenha um papel imunológico importante na glândula mamária (SORDILLO; SHAFER-WEAVER; DEROSA, 1997) através do sequestro do íon férrico livre, tornando-o indisponível para os patógenos dependentes de ferro (SORDILLO; SHAFER-WEAVER; DEROSA, 1997; CHANETON et al., 2008) além da 
capacidade em se ligar à parede celular das bactérias causando a ruptura da membrana externa das Gram-negativas (ELLISON; GIEHL; LAFORCE, 1988). Assim, a lactoferrina, tem efeito bactericida e bacteriostático na glândula mamária da vaca em lactação e sua concentração no leite aumenta durante períodos de estresse imunológico na glândula mamária e durante o período seco e também é negativamente correlacionada com a produção de leite (REJMAN; HURLEY; BAHR, 1989; HAGIWARA et al., 2003; CHENG et al., 2008). Para o final da lactação, cerca de 33 semanas de lactação, a concentração começou a aumentar e atingiu concentração cerca de 3,2 vezes maior na $44^{\circ}$ semana $(10,7 \pm 1,9 \mathrm{mg} / \mathrm{dL})$ (HISS; MEYER; SAUERWEIN, 2008)

Hurley e Rejman (1986) observaram em vacas que o perfil eletroforético (SDS-PAGE) das proteínas do soro a partir de secreções durante o período seco refletiu a mudança na concentração protéica, pois, nenhuma fração tornou-se predominante durante o período, e outras bandas de proteínas menores apareceram. Proteínas com cerca de $37 \mathrm{KDa}$ e $28 \mathrm{KDa}$ aumentaram a partir da metade do período seco, podendo ser, de acordo com os autores, produtos da repartição parcial de $\lg G$ de cadeia pesada durante $o$ transporte através das células epiteliais secretoras. A concentração de $\beta$ - $L g$ e $\alpha$-La diminuiu durante a secagem enquanto que a albumina sérica, lactoferrina e $\lg G$ aumentaram. A diminuição de $\alpha-$ $\mathrm{La}$, segundo os autores resultou na diminuição do complexo lactose-sintetase e como consequência na diminuição da síntese de lactose. Hurley e Rejman (1993) avaliaram a produção in vitro de lactoferrina no tecido mamário de vacas durante a involução e observaram um aumento da síntese dessa proteína nos dias 7 e 14 de involução e diminuição após o $31^{\circ}$ dia.

Durante a lactação, o leite contém uma série de proteases, como plasmina, protease ácida do leite, proteases derivadas de leucócitos no leite $(\mathrm{SHUICHI}$ et al., 1980; RICHARDSON, 1983; POLITIS; BARBANO; GOREWIT, 1992) e componentes séricos do sistema fibrinolítico, como plasminogênio (GRUFFERTY; FOX, 1988). A maior parte da atividade proteolítica encontrada no leite é estimulada pela plasmina (POLITIS et al., 1989) e estão associados com micelas de caseína, mas também estão presentes no soro do leite (KORYCHA-DAHL et al., 1983; POLITIS; BARBANO; GOREWIT, 1992). O sistema plasmina tem um papel importante na glândula mamária durante a involução, pois, o ativador de plasminogênio converte o plasminogênio em plasmina durante o final da lactação, que é associado com o 
início da involução (OSSOWKI; BIEGEL; REICH, 1979). As concentrações de plasminogênio e de plasmina aumentam no leite bovino conforme a lactação progride, e aumenta ainda mais a atividade do plasminogênio três dias, após o início do período seco (POLITIS et al., 1989)

Aslam e Hurley (1997) avaliaram o sistema ativador de plasminogênio (plasminogênio - plasmina) na secreção láctea de bovinos durante a involução da glândula mamária e identificaram os peptídeos gerados por proteólise da caseína e lactoferrina nessa secreção. Segundo os autores o sistema ativador de plasminogênio foi significativamente maior no $7^{\circ}, 14^{\circ}$ e $21^{\circ}$ dia de secagem do que a observada no $7^{\circ}$ dia do pós-parto e no fracionamento por eletroforese SDS-PAGE foram observados peptídeos com massas moleculares que variaram de 13,5 a 2,5 $\mathrm{KDa}$, que são derivados da hidrólise das proteínas, além disso, o aparecimento crescente de bandas com massa molecular acima de $14 \mathrm{kDa}$ sugerem que algumas proteínas estavam presentes parcialmente hidrolisadas. A análise por Imunoblot realizada pelos autores demonstrou que esses fragmentos foram gerados a partir da caseína ( $\beta$-caseína e k-caseína) ou lactoferrina. Segundo os autores a atividade aumentada da plasmina ode ser, a principal responsável pela hidrólise observada na involução da glândula mamária de bovinos. Em caprinos Fantuz et al. (2001) associaram a alta atividade do sistema ativador de plasminogênio com a deterioração da capacidade de coagulação do leite, provavelmente devido a hidrolise da caseína pela plasmina, juntamente com a passagem de proteína sérica para o leite.

Shamay et al. (2003) concluíram que a aplicação experimental de caseína hidrolisada no úbere de vacas induziu perda na integridade das junções celulares, ocasionando diminuição nas concentrações de lactose e caseína, ativando o sistema plasmina/plasminogênio, induzindo a secreção de imunoglobulina $G$ e lactoferrina seguidos por secagem rápida da mama e por resposta inflamatória local.

Segundo Hurley e Junior (2003), ocorre diminuição da concentração de proteínas, gordura e lactose durante as duas primeiras semanas de secagem, enquanto que a concentração de fatores de proteção como lactoferrina e leucócitos aumenta durante o início da involução.

Weng et al. (2006) avaliaram os teores de proteína total e caseína na secreção láctea de cabras durante a secagem. Segundo os autores não houve diferença na concentração de proteína total, contudo a percentagem de caseína 
representava $71,8 \%$ durante a lactação, diminuindo para $30,0 \%$ na glândula pouco ativa, $21,7 \%$ na involução gradual chegando a $6 \%$ da proteína total em glândulas com involução aguda. No mesmo estudo foi observado que a involução aguda induzida pela secagem foi refletida por ativação local do plasminogênio além da degradação da caseína.

Birgel (2006) observou aumento gradual nos teores de proteína total em amostras colhidas entre o primeiro e o décimo quinto dia de secagem em vacas (de $4.220 \mathrm{mg} / \mathrm{dL}$ para $8.950 \mathrm{mg} / \mathrm{dL}$ ). Segundo Brandespim (2007) as alterações nas características da secreção láctea de caprinos durante o período seco ocorrem de forma mais tardia, se comparada com as mudanças ocorridas em bovinos, de acordo com o autor, o teor de proteínas aumentou somente a partir do sétimo dia de secagem.

\subsection{Avaliação da influência do período colostral e do primeiro mês de lactação no proteinograma da secreção láctea de cabras}

No final da gestação e no início da nova lactação ocorrem alterações no parênquima da glândula mamária. $O$ incremento do fluxo sanguíneo fornece os compostos necessários para a síntese do leite ocasionando um aumento no metabolismo das células epiteliais dos alvéolos (KOLB, 1984). A secreção produzida chamada colostro, é sintetizada devido aos efeitos inibitórios da progesterona e do estrógeno em um processo que ocorre na ausência da ordenha (CUNNIGAN, 2004).

A placenta de ruminantes, do tipo sinepitéliocorial, possui um maior número de estratos tissulares que separam a circulação materna da fetal, dificultando a passagem adequada de imunoglobulinas para o feto fazendo com que os neonatos destas espécies sejam hipogamaglobulinêmicos e dependam dos anticorpos absorvidos do colostro. Logo, a transferência bem sucedida de imunoglobulinas colostrais em ruminantes é de suma importância para a sobrevivência do recémnascido (TIZARD 2004).

O colostro, secretado durante as primeiras horas de lactação, possui um conteúdo de matéria seca superior ao leite, devido principalmente, à grande quantidade de proteínas presentes, particularmente as do soro lácteo (JACOBINSON; MC GILLIARD, 1988). A elevada quantidade de proteínas do soro 
no colostro se deve não somente as imunoglobulinas, mas também as demais proteínas que promovem o desenvolvimento e a maturação dos tecidos epiteliais do sistema gastrointestinal do neonato (SGARBIERI, 2004), possuem função antimicrobiana, são carreadoras de minerais, influenciam a utilização dos nutrientes ingeridos, além de serem precursoras de peptídeos que exercem ações em diferentes sistemas (cardiovascular, endócrino, imunológico e nervoso) dependendo da sequência de aminoácidos liberados por proteólise enzimática durante a digestão (GUILLOTEAU et al., 2009).

Na literatura compulsada (Quadro1), independente da técnica utilizada, há um consenso entre vários autores que descrevem a maior concentração de proteínas no colostro, assim como diminuição acentuada dessa concentração ao longo dos dias, em cabras (LINZELL; PEAKER, 1974; QUILES et al., 1991; CHEN et al., 1998; LEVIEUX et al., 2002; ARGÜELLO et al., 2006; RUDOVSKY et al., 2008; YANG; CHEN; ZHANG, 2009) e em vacas (OYENIYI; HUNTER, 1978; MADSEN et al., 2004; SANT'ANA, 2004; SGARBIERI, 2005; TSIOULPAS; GRANDISON; LEWIS, 2007; 2009).

\begin{tabular}{|c|c|c|c|c|c|c|c|c|c|c|c|}
\hline \multicolumn{12}{|c|}{ VACAS } \\
\hline & Oh. & $12 \mathrm{hs}$ & $1^{0}$ & $2^{\circ}$ & 3은 & $4 \%$ & $5^{\circ}$ & $7^{0}$ & $15^{\circ}$ & $30^{\circ}$ & \\
\hline PTotal & & 9.240 & 9.160 & 5.280 & 4.180 & 5.680 & 4.680 & & & & Heng (1000) \\
\hline PSoro & & 8.410 & 7.460 & 4.240 & 3.000 & 4.250 & 1.600 & & & & Heng (1999) \\
\hline PTotal & $\begin{array}{l}11.490 \\
\pm 630 \\
\end{array}$ & $\begin{array}{l}9.400 \\
\pm 400 \\
\end{array}$ & $\begin{array}{l}7.040 \\
\pm 400 \\
\end{array}$ & & & & & & & & Oyeniyi e \\
\hline PSoro & $\begin{array}{l}11.010 \\
\pm 660\end{array}$ & $\begin{array}{l}9.050 \\
\pm 450\end{array}$ & $\begin{array}{r}4.850 \\
\pm 360 \\
\end{array}$ & & & & & & & & Hunter (1978) \\
\hline PTotal & 13.900 & & & & & & & & 3.550 & & $\begin{array}{l}\text { Madsen et al. } \\
(2004)\end{array}$ \\
\hline PTotal & & 10.950 & 8.090 & 4.830 & 4.470 & \multicolumn{2}{|c|}{4.310} & 4.090 & 4.020 & 3.560 & $\begin{array}{l}\text { Raimondo et } \\
\text { al. (2009) }\end{array}$ \\
\hline PTotal & & & $\begin{array}{r}16.120 \\
\pm 1.640\end{array}$ & $\begin{array}{c}5.430 \\
\pm \\
240,0\end{array}$ & $\begin{array}{l}4.540,0 \\
\pm 400,0\end{array}$ & $\begin{array}{l}4.410 \\
\pm 310\end{array}$ & $\begin{array}{l}4.230 \\
\pm 240\end{array}$ & & $\begin{array}{l}4.010 \\
\pm 430\end{array}$ & $\begin{array}{l}3.080 \\
\pm 190\end{array}$ & $\begin{array}{l}\text { Tsioulpas et al. } \\
\text { (2007) }\end{array}$ \\
\hline \multicolumn{12}{|c|}{ CABRAS } \\
\hline & O h. & 12 hs. & $1^{0}$ & $2^{\circ}$ & $3^{\circ}$ & $4^{\circ}$ & $5^{\circ}$ & $7^{\circ}$ & $15^{\circ}$ & 30 은 & \\
\hline PTotal & & & $\begin{array}{r}13.250 \\
\pm 2.670\end{array}$ & $\begin{array}{c}8.430 \\
\pm \\
1.800\end{array}$ & $\begin{array}{c}5.320 \\
\pm 910,0\end{array}$ & $\begin{array}{c}4.680 \\
\pm \\
620,0\end{array}$ & & & & & \multirow{2}{*}{$\begin{array}{l}\text { Quiles, et al. } \\
\quad(1991)\end{array}$} \\
\hline PSoro & & & $\begin{array}{c}6.710 \\
\pm 1.380\end{array}$ & $\begin{array}{c}2.160 \\
\pm \\
530,0\end{array}$ & $\begin{array}{l}1.410 \\
\pm 280\end{array}$ & $\begin{array}{l}1.250 \\
\pm 210\end{array}$ & & & & & \\
\hline \multirow{2}{*}{ PTotal } & & 9.100 & 7.680 & 6.390 & 6.390 & & 5.510 & & & & $\begin{array}{c}\text { Chen et al. } \\
(1998)\end{array}$ \\
\hline & & 7.860 & 6.790 & 6.190 & 6.190 & & 5.470 & & & & $\begin{array}{l}\text { Chen et al. } \\
(1998)\end{array}$ \\
\hline $\begin{array}{l}\text { PTotal } \\
\text { PSoro }\end{array}$ & \begin{tabular}{|l}
13.190 \\
9.050
\end{tabular} & & & & & & & & & & $\begin{array}{c}\text { Caja et al. } \\
\text { (2006) }\end{array}$ \\
\hline PTotal & $\begin{array}{c}14.840 \\
\pm \\
2.890\end{array}$ & & & & & & & & & & $\begin{array}{l}\text { Rudovsky et al } \\
\text { (2008) }\end{array}$ \\
\hline PTotal & & $\begin{array}{r}8.750 \\
\pm 1.970\end{array}$ & $\begin{array}{c}7.810 \\
\pm 2.060\end{array}$ & $\begin{array}{c}7.030 \\
\pm \\
1.880 \\
\end{array}$ & $\begin{array}{r}6.850 \\
\pm 1.760\end{array}$ & & $\begin{array}{c}6.630 \\
\pm \\
1.920\end{array}$ & $\begin{array}{c}5.910 \\
\pm \\
2.170\end{array}$ & & & $\begin{array}{l}\text { Yang et al. } \\
\text { (2009) }\end{array}$ \\
\hline
\end{tabular}

Quadro 1- Concentrações de proteína total e proteína do soro lácteo no início da lactação de acordo com a literatura compulsada 
Linzell e Peaker (1974) avaliaram as alterações na composição do colostro e na permeabilidade da glândula mamária de cabras no pós-parto e afirmaram que as concentrações de sódio, cloreto, proteína e imunoglobulinas diminuem, enquanto que os de potássio e lactose aumentam tudo para níveis semelhantes aos do leite normal com o evoluir dos dias de lactação.

Segundo Quiles et al. (1991) a maioria das pesquisas com colostro de cabras são dedicadas à avaliação físico-química nos primeiros dias pós-parto, e entre os componentes, as imunoglobulinas despertam um grande interesse devido à sua importância na transmissão de imunidade passiva. Radostitis et al. (2000) afirmam que grande parte das pesquisas relacionadas com as imunoglobulinas do colostro foram realizadas em bovinos, todavia, as informações são aplicáveis a outras espécies de ruminantes. No leite de cabra e de vaca a porcentagem de proteína não difere entre as espécies e é menos passível de manipulação dietética do que os teores de gordura em ambas as espécies.

Embora o alto teor de imunoglobulinas no colostro seja conhecido não há um consenso referente ao predomínio protéico que ocorre no início da lactação, pois alguns autores acreditam que ocorre um aumento de todas as proteínas nessa fase (QUILES et al., 1991; AULDIST et al., 1995; CUNNIGAN, 2004; MADSEN et al., 2004; TSIOULPAS; GRANDISON; LEWIS, 2007), enquanto que outros autores associam a maior concentração de proteína no colostro aos menores valores de caseína com um predomínio das proteínas do soro lácteo (OYENIYl; HUNTER, 1978; CHEN et al., 1998; HENG, 1999; SGARBIERI, 2005; CAJA; SALAMA; SUCH, 2006).

Quiles, et al. (1991) avaliaram o proteinograma do colostro de cabras utilizaram o método de Kjeldhal para a obtenção da proteína total e do soro lácteo, a técnica de eletroforese em gel de poliacrilamida com dodecil sulfato de sódio (SDSPAGE) para o fracionamento das proteínas, e o teor de caseína obtido por diferença entre a proteína total e do soro, descreveram correlação positiva $(p<0,001)$ entre proteína total, proteína do soro, frações de proteínas do soro e caseínas.

Chen et al. (1998) sugerem que a síntese de caseína na glândula mamária pode ainda não ser muito ativa durante os primeiros dias pós-parto. Porém, de acordo com Cunningham (2004) além das imunoglobulinas as caseínas e albumina também estão presentes em concentrações relativamente altas no colostro e diminuem após três dias de lactação, enquanto que os teores de lactose, cuja 
síntese é significativamente inibida pela progesterona até a época do parto, são mínimos.

Segundo Lopez et al. (1988) a associação entre, proteína do soro e as concentrações de gamaglobulina no colostro sugere que a concentração de proteína do soro pode ser utilizada para determinar a qualidade do colostro, pois, a concentração média de gamaglobulina obtida pelos autores no colostro de vacas correspondeu a $62,4 \%$ do total de proteína.

Rota et al. (1993) estudaram os teores de proteína no decorrer da lactação de caprinos através da técnica de radiação infravermelha e observaram diminuição dos valores médios com o decorrer da lactação, valores estes que foram iguais a 5.500 $\mathrm{mg} / \mathrm{dL}, 3.160 \mathrm{mg} / \mathrm{dL}$ e $3.400 \mathrm{mg} / \mathrm{dL}$ para amostras colhidas entre $0-7$ dias; 8-28 dias e 29-49 dias de lactação em animais pluríparas

O colostro de ruminantes é principalmente caracterizado por um alto teor de imunoglobulinas, sendo que a classe $\mathrm{G}$ ( $\mathrm{lgG}$ ) corresponde cerca de $80 \%$ do total, em especial a subclasse $\lg _{1}$ que corresponde entre 80 e $90 \%$ do total da classe $G$, devido a receptores ativos e seletivos que proporcionam sua transferência do sangue para o epitélio secretório da mama durante as últimas semanas antes do parto. As outras classes de imunoglobulinas também estão presentes, porém em menor quantidade, a classe $\mathrm{M}$ (IgM) corresponde cerca de $7 \%$ enquanto que a classe A cerca de $5 \%$ do total de imunoglobulinas presentes no colostro (PAHUD; MACH, 1970; MICUSAN; BORDUAS, 1976; HALLIDAY, 1978; LARSON; HEARY JR.; DEVERY, 1980; RADOSTITS et al., 2000; YANG; CHEN; ZHANG, 2009).

Sasaki, Davis e Larson (1976) estudaram a produção e o transporte de imunoglobulinas $\lg G_{1}$ e $\lg G_{2}$ no período pré e pós-parto em vacas através da infusão contínua de imunoglobulinas marcadas com soluções isotópicas. Os autores verificaram um aumento significante na produção e na taxa de transferência de IgG1 ocorrendo no período próximo ao parto o que explica a grande quantidade de imunoglobulina $\lg G_{1}$ juntamente com pequena quantidade de imunoglobulina $\lg G_{2}$ no colostro. A taxa máxima de transferência foi observada entre o $1^{\circ}$ e $3^{\circ}$ dia antes do parto coincidindo com o surgimento de sítios de ligação para $\lg G_{1}$.

Em estudos anteriores, vários métodos laboratoriais foram utilizados para avaliar a concentração de imunoglobulinas no colostro de cabras, como a eletroforese SDS-PAGE (QUILES et al., 1991; ROCHA et al., 2009), eletroforese em gel de agarose (CHEN et al., 1998) e imunodifusão radial (OYENIYl; HUNTER, 
1978; SANTOS et al., 1994; LEVIEUX et al., 2002; ARGÜELLO et al., 2006) e a técnica de Imunoensaio de enzima de anticorpo (ELISA) (CHIGERWE et al., 2005; RUDOVSKY et al., 2008). Independentemente da técnica utilizada houve um consenso entre os referidos autores, que descreveram diminuição na concentração de imunoglobulinas com o evoluir da lactação.

Oyeniyi e Hunter (1978) avaliaram as imunoglobulinas no colostro de vacas nas três primeiras ordenhas, observaram diminuição nas concentrações durante as primeiras horas de lactação $(p<0,01)$. Os autores encontraram concentrações médias de imunoglobulinas iguais a $3.240 \pm 180,0 \mathrm{mg} / \mathrm{dL}$ logo após o parto, $2.540 \pm$ $160,0 \mathrm{mg} / \mathrm{dL} 12$ horas pós-parto e $1.540 \pm 130,0 \mathrm{mg} / \mathrm{dL} 24$ horas pós-parto.

Quiles et al. (1991) referiram que a concentração da fração nominada como "outras proteínas" variou entre $3.500 \mathrm{mg} / \mathrm{dL}$ e $690,0 \mathrm{mg} / \mathrm{dL}$ nos 2 primeiros dias pósparto e, de acordo com os autores essa queda abrupta é atribuída devido essa fração ser composta principalmente por imunoglobulinas que são responsáveis pela imunidade do neonato nas primeiras horas após o parto. Segundo Santos et al. (1994), a concentração de IgG no colostro caprino variou de 6.930 a $21.780 \mathrm{mg} / \mathrm{dL}$ na primeira secreção e reduziu aproximadamente $50 \%$ nas primeiras 12 horas. Os autores encontraram no momento do parto concentrações de imunoglobulinas iguais a $12.598 \mathrm{mg} / \mathrm{dL}$ valores estes que decaem para $3.407,0 \mathrm{mg} / \mathrm{dL} 10$ horas após o parto.

Chen et al. (1998) observaram diminuição nas concentrações de imunoglobulina em dois rebanhos de cabras da raça Nubiana durante os primeiros 5 dias de lactação. As concentrações nas amostras colhidas com 12 horas de lactação foram iguais a $3.940 \pm 660,0 \mathrm{mg} / \mathrm{dL}$ e $2.400 \pm 500,0 \mathrm{mg} / \mathrm{dL}$ esses valores decaem abruptamente em ambos os rebanhos nas amostras colhidas com 24 horas de lactação $(2.490 \pm 450,0 \mathrm{mg} / \mathrm{dL}$ e $1.150 \pm 260,0 \mathrm{mg} / \mathrm{dL})$ e continuam decaindo chegando a 460,0 $\pm 120,0 \mathrm{mg} / \mathrm{dL}$ e $330 \pm 40,0 \mathrm{mg} / \mathrm{dL}$ no $5^{\circ}$ dia de lactação.

A concentração de IgG no colostro bovino diminui conforme o tempo de lactação, sendo que o teor médio de lgG entre 12 horas e 72 horas após o parto são respectivamente iguais a $6.150 \mathrm{mg} / \mathrm{dL}$ e $600,0 \mathrm{mg} / \mathrm{dL}$, enquanto que os teores de lgG no leite bovino é igual a 50,0 mg/dL (HENG, 1999).

Levieux e Ollier (1999) avaliaram a concentração de IgG na primeira ordenha de vacas obtiveram médias iguais a $5.980 \mathrm{mg} / \mathrm{dL}$. Posteriormente, a concentração de IgG diminuiu acentuadamente a 100,0 mg/dL entre o $6^{\circ}$ e $7^{\circ}$ dia de lactação. Os 
autores observaram concentração de $\lg$ entre $01^{\circ}$ e $\circ 5^{\circ}$ dia de lactação significativamente $(p<0,01)$ maior do que no $8^{\circ}$ dia.

Levieux et al. (2002) obtiveram na primeira ordenha a concentração média de IgG igual a $4.700 \mathrm{mg} / \mathrm{dL}$, em seguida essa concentração decai acentuadamente até o $3^{\circ}$ e $4^{\circ}$ dia de lactação, apresentando média igual a $73 \mathrm{mg} / \mathrm{dL}$ na $13^{\mathrm{a}}$ ordenha $\left(7^{\circ}\right.$ dia de lactação). Os autores relataram que a concentração de lgG obtidas entre a $1^{\text {a }}$ e $6^{\text {a }}$ ordenha (1 a 3 dias de lactação) são significativamente maiores do que as obtidas na $14^{\mathrm{a}}$ ordenha ( $7^{\circ}$ dia de lactação).

Em uma revisão de literatura referente às proteínas do soro de leite bovino Sgarbieri (2004) descreveu diminuição na concentração de IgG nos primeiros dias pós-parto, com concentrações iguais a $6.150 \mathrm{mg} / \mathrm{dL} 12$ horas pós-parto, 4.000 $\mathrm{mg} / \mathrm{dL} 24$ horas pós-parto, $1.360 \mathrm{mg} / \mathrm{dL}$ no $2^{\circ}$ dia de lactação, $600,0 \mathrm{mg} / \mathrm{dL}$ no $3^{\circ}$ dia de lactação e $50 \mathrm{mg} / \mathrm{dL}$ no leite.

Argüello et al. (2006) avaliaram a concentração de IgG no colostro de cabras observaram diminuição abrupta das concentrações desde o nascimento até 36 horas após o parto, em seguida os teores continuam diminuindo, porém mais lentamente, um significativo efeito do tempo $(p<0.001)$ sobre a evolução da concentração de IgG no colostro de cabras foi encontrado.

Rudovsky et al. (2008) avaliaram o colostro de cabras utilizando amostras colhidas 30 minutos após o parto. Os autores encontraram concentrações de imunoglobulinas mensuradas por ELISA iguais a $5.440 \pm 2.640 \mathrm{mg} / \mathrm{dL}$ e médias maiores obtidas por eletroforese em gel de agarose $(6.930 \pm 2.560 \mathrm{mg} / \mathrm{dL})$, o método de ELISA é considerado o método mais preciso para a determinação da concentração e é usado como método de referência (CHIGERWE et al., 2005).

Yang, Chen e Zhang (2009) encontraram teores médios de imunoglobulinas no colostro de cabras nas primeiras 12 horas de lactação iguais a $4.181 \pm 286,0$ $\mathrm{mg} / \mathrm{dL}$ e no $1^{\circ}$ dia iguais a $1.686 \pm 351,0 \mathrm{mg} / \mathrm{dL}$ a seguir os valores decaem a valores médios iguais a $540,0 \pm 247,0 \mathrm{mg} / \mathrm{dL}$ no $2^{\circ} \mathrm{dia}, 197,0 \pm 227,0 \mathrm{mg} / \mathrm{dL}$ no $3^{\circ}$ dia, $122,0 \pm 304,0 \mathrm{mg} / \mathrm{dL}$ no $5^{\circ}$ dia e $54,0 \pm 243,0 \mathrm{mg} / \mathrm{dL}$, no $7^{\circ}$ dia de lactação.

Rocha et al. (2009) avaliaram as imunoglobulinas do colostro de vacas da raça Canchim primíparas e pluríparas através da técnica de eletroforese SDS-PAGE observaram concentrações superiores no dia do parto $(3.416 \pm 1.244 \mathrm{mg} / \mathrm{dL}$ e $3.740 \pm 1.066 \mathrm{mg} / \mathrm{dL}$, em primíparas e pluríparas, respectivamente para cadeia pesada e $4.222 \pm 1.490 \mathrm{mg} / \mathrm{dL}$, em primíparas, e $3.669 \pm 1.237 \mathrm{mg} / \mathrm{dL}$, em pluríparas 
para cadeia leve). Nos momentos subsequentes estudados pelos autores foram observados valores intermediários no $1^{\circ}$ dia $(842 \pm 486 \mathrm{mg} / \mathrm{dL}$, em primíparas, e $760 \pm 810 \mathrm{mg} / \mathrm{dL}$, em pluríparas na cadeia pesada e $867 \pm 886 \mathrm{mg} / \mathrm{dL}$ e $507 \pm 671$ $\mathrm{mg} / \mathrm{dL}$, respectivamente para cadeia leve) e valores inferiores no final do $1^{\circ}$ mês de lactação $(6,86 \pm 11,1 \mathrm{mg} / \mathrm{dL}$, em primíparas e $12,9 \pm 10,2 \mathrm{mg} / \mathrm{dL}$, em pluríparas para cadeia pesada e $11,8 \pm 22,2 \mathrm{mg} / \mathrm{dL}$ e $6,07 \pm 10,1 \mathrm{mg} / \mathrm{dL}$, respectivamente para cadeia leve).

As demais proteínas do soro lácteo também são abundantes no início da lactação. De acordo com Quiles et al. (1991); Levieux et al. (2002); Baroza (2007) e Rocha et al. (2009) as concentrações de $\alpha$-lactoalbumina ( $\alpha$-La) e $\beta$-lactoglobulina $(\beta-\mathrm{Lg})$, são maiores no colostro de cabras quando comparadas com o leite maduro. Essas concentrações diminuem com 0 evoluir da lactação, entretanto 0 comportamento das frações difere, pois, a fração $\beta$-Lg diminui abruptamente nos primeiros dias após o parto, enquanto que a diminuição da fração $\alpha$-La é menor e mais gradual (PEREZ et al., 1990; QUILES et al., 1991; LEVIEUX; OLLIER, 1999; LEVIEUX et al., 2002).

A maior concentração de $\beta$ - $\mathrm{Lg}$ foi encontrada no primeiro dia de lactação (1.890,0 mg/dL em vacas e 1.730,0 mg/dL em ovelhas). Esta concentração diminui nas primeiras 24 horas para cerca de $40 \%$ do valor inicial e cerca de $30 \%$ no 3 dia pós-parto, reduzindo gradativamente até estabilizar na $2^{\text {a }}$ semana de lactação $(390,0$ $\mathrm{mg} / \mathrm{dL}$ em vacas e $410,0 \mathrm{mg} / \mathrm{dL}$ em ovelhas) sendo aproximadamente $20 \%$ do valor inicial. A $\alpha$-La também foi maior no primeiro dia $(200,0 \mathrm{mg} / \mathrm{dL}$ em vacas e 230,0 $\mathrm{mg} / \mathrm{dL}$ em ovelhas). Contudo a diminuição no período colostral é menor do que a $\beta$ Lg. Em 24 horas os níveis eram de 95\% do seu valor inicial e em três dias de $80 \%$. Estes teores diminuem para 130,0 mg/dL em vacas e $160,0 \mathrm{mg} / \mathrm{dL}$ em ovelhas na segunda semana de lactação, sendo cerca de $70 \%$ do valor inicial mantendo-se praticamente constantes. A relação $\beta-\mathrm{Lg} / \alpha-\mathrm{La}$ foi igual a 9 no primeiro dia de lactação e 3 no leite maduro, indicando que a concentração de $\beta$ - Lg foi comparativamente maior que a $\alpha$-La no período colostral (PEREZ et al., 1990).

A concentração de $\alpha$-La no colostro de cabras foi igual a $940,0 \pm 290 \mathrm{mg} / \mathrm{dL}$ no primeiro dia de lactação, $310,0 \pm 120,0 \mathrm{mg} / \mathrm{dL}$ no segundo dia, 170,0 $\pm 60,0 \mathrm{e}$ $140,0 \pm 30,0 \mathrm{mg} / \mathrm{dL}$ no terceiro e quarto dia de lactação respectivamente. A fração $\beta$ Lg diminui nos primeiros quatro dias de lactação sendo encontrado médias iguais a $2.230,0 \pm 740,0 \mathrm{mg} / \mathrm{dL}$ no primeiro dia $1.160,0 \pm 290,0 \mathrm{mg} / \mathrm{dL}$ no segundo dia, 850,0 
$\pm 180,0$ no terceiro dia e 780,0 $\pm 140,0 \mathrm{mg} / \mathrm{dL}$ no quarto dia de lactação (QUILES et al., 1991). De acordo com Chen et al. (1998) as frações $\alpha$-La e $\beta$-Lg são estáveis em cabras durante os primeiros cinco dias de lactação, sendo que as concentrações aumentam conforme diminuem os teores de imunoglobulinas.

Heng (1999) avaliou a composição química do colostro de bovinos encontrou concentrações máximas de $\alpha$-La e $\beta$-Lg nas primeiras 12 horas de lactação $(84,0$ e $3.980,0 \mathrm{mg} / \mathrm{dL}$ respectivamente). As concentrações de $\alpha$-La se diminuem lentamente nas primeiras 48 horas de lactação com teores iguais a 85,0 e $81,0 \mathrm{mg} / \mathrm{dL}$ no $1^{\circ}$ e $2^{\circ}$ dia respectivamente, diminuindo abruptamente no $3^{\circ}$ dia chegando a $23,6 \mathrm{mg} / \mathrm{dL}$. As concentrações de $\beta$ - $\mathrm{Lg}$ são superiores as de $\alpha$-La e diminuem abruptamente durante os 3 primeiros dias de lactação com teores iguais a $265,4 \mathrm{mg} / \mathrm{dL}$ no $1^{\circ}$ dia, 194,2 $\mathrm{mg} / \mathrm{dL}$ no $2^{\circ}$ dia, chegando a $61,8 \mathrm{mg} / \mathrm{dL}$ no $3^{\circ}$ dia de lactação.

A concentração de $\beta-\mathrm{Lg}$ no colostro de vacas variou entre 790,0 a 3000 $\mathrm{mg} / \mathrm{dL}$, decaindo acentuadamente após a $1^{1 \mathfrak{a}}$ ordenha e, em seguida, diminuindo mais lentamente até o $8^{\circ}$ dia. A produção de $\beta$ - Lg foi relativamente constante, uma vez que a diminuição da concentração foi compensada por um aumento na produção de leite. Os teores de $\alpha$-La diminuem lentamente e regularmente, mas devido ao aumento progressivo do volume de leite, a produção foi relativamente constante entre $\circ 2^{\circ}$ e $8^{\circ}$ dia. As concentrações de ambas as proteínas foram maiores na 1ำ semana de lactação de vacas (LEVIEUX; OLLIER, 1999)

As frações $\alpha$-La e $\beta$ - $L g$ foram avaliadas por imunodifusão radial durante 0 início da lactação de vacas por Levieux et al. (1999). A concentração inicial de $\beta$-Lg variou entre 790 e $3.000 \mathrm{mg} / \mathrm{dL}$ na $1^{\circ}$ ordenha decaindo acentuadamente no $1^{\circ}$ dia de lactação, a seguir a diminuição passa a ser mais gradual até o $8^{\circ}$ dia de lactação chegando a 420,0 $\pm 75,0 \mathrm{mg} / \mathrm{dL}$ no final do primeiro mês de lactação. A $\alpha$-La diminuiu lentamente e regularmente, porém, devido ao aumento progressivo do volume de leite, o seu rendimento foi relativamente constante entre o $1^{\circ}$ e o $8^{\circ}$ dia de lactação. As concentrações obtidas nos 3 primeiros dias foram significativamente superior do que no $8^{\circ}$ dia, chegando a concentrações iguais a $139,0 \pm 25,0 \mathrm{mg} / \mathrm{dL}$ no $30^{\circ}$ dia.

Em cabras Levieux et al. (2002) observaram concentração máxima de $\beta$-Lg no dia do parto (3.070 $\pm 1.040 \mathrm{mg} / \mathrm{dL})$ que diminuiu abruptamente no $1^{\circ}$ dia de lactação e mais lentamente até o final da $1^{\underline{a}}$ semana do pós-parto. As concentrações obtidas pelos autores nos três primeiros dias foram significativamente maiores quando 
comparadas com as obtidas no $7^{\circ}$ dia. As concentrações de $\alpha$-La foram máximos no dia do parto $(2.770 \pm 820,0 \mathrm{mg} / \mathrm{dL}$ ) e decaem lentamente com o evoluir dos dias de lactação, sendo encontradas as maiores concentrações nas primeiras 24 horas de lactação

Segundo Sgarbieri (2004) a concentração de $\alpha$-La e $\beta$-Lg no colostro bovino diminuem com o evoluir da lactação. As concentrações máximas foram observada nas primeiras 12 horas de lactação $840,0 \mathrm{mg} / \mathrm{dL}$ e $3.988 \mathrm{mg} / \mathrm{dL}$ para as frações $\alpha$-La e $\beta$ - $\mathrm{Lg}$ respectivamente. As concentrações de $\alpha$-La diminuem lentamente nos primeiros dias de lactação $856,0 \mathrm{mg} / \mathrm{dL}$ no $1^{\circ}$ - dia e $812,0 \mathrm{mg} / \mathrm{dL}$ no $2^{\circ}$ dia chegando a $236 \mathrm{mg} / \mathrm{dL}$ no $3^{\circ}$ dia pós-parto. As concentrações de $\beta$ - $\mathrm{Lg}$ diminuem abruptamente nos 3 primeiros dias de lactação, $2.654 \mathrm{mg} / \mathrm{dL}$ no $1^{\circ}$ dia; $1.942,0$ no $2^{\circ}$ dia e 618,0 $\mathrm{mg} / \mathrm{dL}$ no $3^{\circ}$ dia. Segundo o autor as concentrações de $\alpha$-La e $\beta$ - $L g$ no leite bovino são respectivamente iguais a $200,0 \mathrm{mg} / \mathrm{dL}$ e $400,0 \mathrm{mg} / \mathrm{dL}$.

Baroza (2007) estudou o colostro e o leite de cabras durante o primeiro mês de lactação através da técnica de eletroforese SDS-PAGE. No dia do parto os teores de $\alpha$-La e $\beta$-Lg foram respectivamente iguais a $1.446 \pm 300,0 \mathrm{mg} / \mathrm{dL}$ e $3.662 \pm 604,0$ $\mathrm{mg} / \mathrm{dL}$, logo após a autora descreve diminuição gradual dessas proteínas ao longo do primeiro mês de lactação com valores de $\alpha$-La iguais a $545 \pm 42,0 \mathrm{mg} / \mathrm{dL}$ no $1^{\circ}$ dia, $556 \pm 32,0 \mathrm{mg} / \mathrm{dL}$ no $3^{\circ} \mathrm{dia}, 664 \pm 116,0$ no $5^{\circ} \mathrm{dia}, 414 \pm 23,0 \mathrm{mg} / \mathrm{dL}$ no $14^{\circ} \mathrm{dia}$ chegando a $378 \pm 44,0 \mathrm{mg} / \mathrm{dL}$ no $29^{\circ}$ dia e valores de $\beta$ - $\mathrm{Lg}$ iguais a $1.157 \pm 100,0$ $\mathrm{mg} / \mathrm{dL}$ no $1^{\circ} \mathrm{dia}, 1.022 \pm 48,0 \mathrm{mg} / \mathrm{dL}$ no $3^{\circ} \mathrm{dia}, 1.276 \pm 200,0$ no $5^{\circ} \mathrm{dia}, 771 \pm 41,0$ $\mathrm{mg} / \mathrm{dL}$ no $14^{\circ}$ dia chegando a $576 \pm 45,0 \mathrm{mg} / \mathrm{dL}$ no $29^{\circ}$.

Rocha et al. (2009) avaliaram as proteínas do colostro de vacas primíparas e pluríparas através da técnica de eletroforese SDS-PAGE. Segundo os autores a concentração de $\beta$ - $\mathrm{Lg}$ foi superior no dia do parto em primíparas $5.081 \pm 2.535$ $\mathrm{mg} / \mathrm{dL}$, e pluríparas $3.643 \pm 1.096 \mathrm{mg} / \mathrm{dL}$ e no $1^{\circ}$ dia em primíparas $2.626 \pm 2.708$ $\mathrm{mg} / \mathrm{dL}$ e $1.300 \pm 363 \mathrm{mg} / \mathrm{dL}$ em pluríparas. Nas primíparas foram observados valores inferiores no $30^{\circ}$ dia ( $713 \pm 238 \mathrm{mg} / \mathrm{dL}$ ), nas pluríparas não foi observado diferença a partir do $1^{\circ}$ dia de lactação chegando a $796 \pm 98,2 \mathrm{mg} / \mathrm{dL}$ no final do $1^{\circ}$ mês de lactação. Os teores de $\alpha$-La diferiram no $1^{\circ}$ dia entre primíparas (146 $\pm 71,0 \mathrm{mg} / \mathrm{dL}$ ) e pluríparas $\left(266 \pm 75,1 \mathrm{mg} / \mathrm{dL}\right.$ ) e no $15^{\circ}$ dia em primíparas (145 $\pm 44,1 \mathrm{mg} / \mathrm{dL}$ ), e pluríparas $(215 \pm 32,7 \mathrm{mg} / \mathrm{dL})$ e no $30^{\circ}$ dia $(119 \pm 48,5 \mathrm{mg} / \mathrm{dL}$ e $181 \pm 56,6)$ em primíparas e pluríparas respectivamente. Além das diferenças entre o número de 
lactações os autores observaram concentrações mais altas dessas frações no colostro e diminuição ao longo do primeiro mês de lactação.

A lactoferrina é uma glicoproteína que se liga ao ferro exercendo efeitos protetores ao neonato e foi usada para reduzir a morbidade e melhorar o crescimento em bezerros (ROBBLEE et al., 2003). Nas amostras de colostro, a lactoferrina tem efeitos protetores para o recém-nascido, durante as últimas semanas de lactação, ela age como um protetor para a glândula mamária. (HISS; MEYER; SAUERWEIN, 2008). Na literatura compulsada há discrepância nos valores de lactoferrina encontrados no colostro possivelmente devido as diferentes técnicas utilizadas (TSUJI et al., 1990; YOSHIDA et al., 2000). De acordo com Masson e Heremans (1971) o colostro bovino contém concentrações menores lactoferrina quando comparado com outras espécies.

Segundo Sanchez et al. (1988) as maiores concentrações de lactoferrina foram encontradas na primeira ordenha $(83,0 \mathrm{mg} / \mathrm{dL})$, diminuindo durante os primeiros dias de lactação (período colostral). Posteriormente, a concentração desta proteína diminui lentamente, atingindo seus valores definitivos durante a $3^{\mathrm{a}}$ semana após o parto $(9,0 \mathrm{mg} / \mathrm{dL})$. Através da técnica de imunodifusão radial Tsuji et al. (1990) encontraram concentrações de lactoferrina no colostro colhido 24 horas pósparto iguais a $196 \pm 27 \mathrm{mg} / \mathrm{dL}$ em vacas da raça Holandesa e iguais a $211 \pm 36$ $\mathrm{mg} / \mathrm{dL}$ em vacas da raça Jersey.

Heng (1999) estudou a composição química do colostro bovino observaram diminuição nos teores de lactoferrina nas primeiras 48 horas de lactação encontrando valores iguais a 428,0 mg/dL, $177 \mathrm{mg} / \mathrm{dL}$, e $94,0 \mathrm{mg} / \mathrm{dL}$ nas 12, 24 e 48 horas após o parto respectivamente. Yoshida et al. (2000) encontraram no colostro bovino concentrações de lactoferrina iguais a $33,6 \mathrm{mg} / \mathrm{dL}$ enquanto que, as concentrações máximas de lactoferrina foram observadas nas amostras de colostro 6 horas pós-parto $(38,7 \pm 6,9 \mathrm{mg} / \mathrm{dL})$.

No estudo das proteínas do colostro de cabras através da técnica de eletroforese SDS-PAGE, Baroza (2007) observou diminuição da concentração de lactoferrina durante 0 1 mês de lactação, pois os valores máximos obtidos no dia do parto iguais a $396 \pm 78 \mathrm{mg} / \mathrm{dL}$ diminuíram abruptamente no $1^{\circ}$ dia de lactação $(98,3$ $\pm 17 \mathrm{mg} / \mathrm{dL})$ e mais lentamente a partir do $3^{\circ}$ dia e $5^{\circ}$ dia $(40.4 \pm 10$ e $52,6 \pm$ $16 \mathrm{mg} / \mathrm{dL})$ mantendo-se estáveis até o $14^{\circ}$ dia $(33,1 \pm 12 \mathrm{mg} / \mathrm{dL})$ chegando ao valor mínimo no $29^{\circ}$ dia de lactação $(28,0 \pm 6,5 \mathrm{mg} / \mathrm{dL})$. Concentrações máximas também 
foram observadas nas amostras de colostro de cabras $(38,7 \pm 6,9 \mathrm{mg} / \mathrm{dL})$ que na $1^{\mathrm{a}}$ semana de lactação, diminuiu a menos de $20 \%$ (6,2 $\pm 2,5 \mathrm{mg} / \mathrm{dL}$ ) (HISS; MEYER; SAUERWEIN, 2008).

A concentração de lactoferrina não diferiu vacas de diferentes lactações, os valores superiores foram observados logo após o parto $(335 \pm 145 \mathrm{mg} / \mathrm{dL}$, em primíparas, e pluríparas $360 \pm 150 \mathrm{mg} / \mathrm{dL}$ ), logo após os teores decaem chegando a $92,5 \pm 125 \mathrm{mg} / \mathrm{dL}$ e $64,7 \pm 87,3 \mathrm{mg} / \mathrm{dL}$, em primíparas e pluríparas respectivamente, no $1^{\circ}$ dia de lactação, valores inferiores foram observados no final do primeiro mês de lactação $(14,9 \pm 17,3 \mathrm{mg} / \mathrm{dL}$, e $10,3 \pm 4,76$ em primíparas e pluríparas respectivamente) (ROCHA et al., 2009).

A variação considerável na concentração de albumina sérica observada no início da lactação reflete o estado inflamatório do úbere ao parto uma vez que apenas 10 a $20 \%$ da albumina do soro de leite é sintetizado pela glândula mamária (PHILLIPPY; MCCARTHY, 1979). Shamay et al. (2005) em sua pesquisa sugerem que a secreção de albumina pela glândula mamária é parte do sistema da defesa inata e que sua produção aumenta localmente nos processos inflamatórios. Os teores de albumina sérica elevados no início da lactação diminuem abruptamente durante os três primeiros três dias, no colostro de cabras e vacas (PEREZ et al., 1989; HENG, 1999; LEVIEUX; OLLIER, 1999; LEVIEUX et al., 2002; SGARBIERI, 2004; BAROZA, 2007; ROCHA et al., 2009)

Perez et al. (1989) obtiveram em vacas teores de albumina sérica iguais a $263 \mathrm{mg} / \mathrm{dL}$ na primeira ordenha, teores esses que decaem nas primeiras 24 horas para 79,0 mg/dL e nos primeiros 3 dias pós-parto os teores chegam a 41,0 mg/dL. Após 2 semanas após o parto os teores de albumina foram iguais a 20,0 mg/dL permanecendo estáveis até o final da lactação. Concentrações máximas de albumina $(521,0 \mathrm{mg} / \mathrm{dL})$ foram demonstradas por Heng (1999) no colostro bovino, essas concentrações decaem abruptamente para $197 \mathrm{mg} / \mathrm{dL}$ no $1^{\circ}$ dia de lactação e continuam diminuindo mais lentamente no $2^{\circ}$ dia $(115,0 \mathrm{mg} / \mathrm{dL})$ chegando a 44,0 $\mathrm{mg} / \mathrm{dL}$ no $3^{\circ}$ dia de lactação.

Levieux e Ollier (1999) observaram que os teores de albumina sérica no colostro de cabras decaem abruptamente entre a $1^{\underline{a}}$ e a $5^{\mathrm{a}}$ ordenha em seguida a diminuição passa a ser mais lenta, contudo as concentrações obtidas nos três primeiros dias de lactação foram significativamente maiores do que as observadas no $7^{0}$ dia de lactação. No colostro de cabras Levieux et al. (2002) obtiveram na 
primeira ordenha médios de albumina iguais a $297 \pm 246 \mathrm{mg} / \mathrm{dL}$ que decaíram acentuadamente entre até a $3^{\mathrm{a}}$ ordenha em seguida decaindo de maneira mais lenta. Os autores observaram que as concentrações de albumina nas 3 primeiras ordenhas foram significativamente $(p>0,05)$ quando comparadas com as obtidas na $14^{\circ}$ ordenha, ou seja, no $7^{\circ}$ dia de lactação.

Sgarbieri (2004) observaram diminuição nos teores de albumina nos primeiros três dias de lactação em vacas. Segundo o autor as concentrações de albumina sérica nas primeiras 12 horas de lactação foi igual a $521 \mathrm{mg} / \mathrm{dL}$, teores esses que diminuem abruptamente para $191 \mathrm{mg} / \mathrm{dL}$ no $1^{\circ}=\mathrm{dia}, 115 \mathrm{mg} / \mathrm{dL}$ no $2^{\circ}$ dia chegando a $44,0 \mathrm{mg} / \mathrm{dL}$ no $3^{\circ}$ dia de lactação.

Baroza (2007) avaliou os teores de albumina plasmática na secreção láctea de cabras nos primeiros 30 dias de lactação e observou uma queda abrupta, de modo semelhante, na determinação da concentração de albumina por métodos bioquímicos e através do fracionamento por eletroforese SDS-PAGE com o passar dos dias. A autora encontrou concentrações de albumina iguais a $1.025 \pm 285 \mathrm{mg} / \mathrm{dL}$ no dia do parto, $359 \pm 164 \mathrm{mg} / \mathrm{dL}$ no $1^{\circ}$ dia, $99,4 \pm 13 \mathrm{mg} / \mathrm{dL}$ no $3^{\circ} \mathrm{dia}, 94,2 \pm$ $13 \mathrm{mg} / \mathrm{dL}$ no $5^{\circ} \mathrm{dia}, 52,6 \pm 11 \mathrm{mg} / \mathrm{dL}$ no $14^{\circ}$ dia e $58,0 \pm 9,3 \mathrm{mg} / \mathrm{dL}$ no $29^{\circ}$ dia de lactação.

Rocha et al. (2009) através da técnica de eletroforese SDS-PAGE avaliaram o colostro de vacas primíparas e pluríparas e notaram diferença significativa no teor de albumina logo após o parto entre os grupos, com valores superiores nas pluríparas (321 $\pm 128 \mathrm{mg} / \mathrm{dL}$ ) quando comparados com as primíparas $(227 \pm 85,9 \mathrm{mg} / \mathrm{dL})$. Nos demais momentos segundo os autores, não houve diferença entre o número de parições e, foi observada redução na concentração desta proteína no decorrer do primeiro mês de lactação. Valores intermediários foram observados no $1^{\circ}$ dia (76,6 $\pm 92,3 \mathrm{mg} / \mathrm{dL}$, nas primíparas, e $74,7 \pm 64,1 \mathrm{mg} / \mathrm{dL}$, nas pluríparas) e teores inferiores no $15^{\circ}$ dia de lactação $(9,76 \pm 11,9 \mathrm{mg} / \mathrm{dL}$ e $16,3 \pm 7,47 \mathrm{mg} / \mathrm{dL}$, em primíparas e pluríparas, respectivamente). 


\subsection{Proteinograma do leite de cabras durante a lactação plena: valores de referência e influência da fase de lactação e do número de lactações}

As proteínas do leite são, na sua grande maioria, sintetizadas na glândula mamária, durante a galactopoiese, por células altamente diferenciadas - as células secretoras alveolares, ou, em menor quantidade, são sintetizadas fora dos tecidos mamários, ou seja, tem origem plasmática (SCHALM; CARROLL; JAIN, 1971). A produção de leite e as mudanças que ocorrem no decorrer da lactação dependem do número de células epiteliais secretoras envolvidas na síntese do leite, que é mantido pelo equilíbrio entre a taxa de proliferação e apoptose celular (CAPUCO et al., 2003), pela capacidade secretora dessas células, que é afetada por sua diferenciação e pelo fornecimento de nutrientes através do sistema vascular que sustenta a síntese de leite (AKERS, 2002)

O aumento dos teores de proteína total com diminuição dos teores de caseína e aumento dos teores de proteínas de origem plasmática no soro lácteo representa sintoma evidente de alteração da glândula mamária (SCHALM; CARROLL; JAIN, 1971). Comprovou-se, nas mamites o aumento no soro lácteo dos teores de proteínas de origem plasmática em decorrência das alterações na permeabilidade dos vasos devido ao processo inflamatório (SANT'ANA 2004). Dentre os fatores responsáveis pelas alterações na composição protéica do leite merecem destaque não somente aqueles decorrentes das mamites, mas também fatores fisiológicos de variação como a fase de lactação e o número de lactações.

Diversos autores em vários países avaliaram o teor médio de proteínas no leite de cabras, e obtiveram resultados que variaram entre $2.830 \mathrm{mg} / \mathrm{dL}$ a 3.880 $\mathrm{mg} / \mathrm{dL}$ de acordo com a raça e com a região avaliada: Rota et al. (1993), na região de Cáceres na Espanha, observaram valores médios de proteína iguais a 3.500 mg/dL; Zeng e Escobar (1995) nos Estados Unidos encontraram valores médios de proteína no leite de cabras da raça Nubiana iguais a $3.600 \mathrm{mg} / \mathrm{dL}$ e para o leite de cabras da raça Alpina valores iguais a $2.880 \mathrm{mg} / \mathrm{dL}$; Sung, Wu e Wang (1999) em um trabalho realizado em Taiwan obtiveram para as várias raças estudadas, os seguintes valores médios de proteína no leite: raça Alpina $3.080 \mathrm{mg} / \mathrm{dL}$, raça Nubiana $4.230 \mathrm{mg} / \mathrm{dL}$, raça Saanen $3.250 \mathrm{mg} / \mathrm{dL}$ e raça Toggenburg $3.210 \mathrm{mg} / \mathrm{dL}$; Moatsou et al. (2008) encontraram em cabras locais da Grécia concentrações de 
proteína igual a $3.880 \mathrm{mg} / \mathrm{dL}$ e em cabras de raças internacionais valores iguais a $3.190 \mathrm{mg} / \mathrm{dL}$.

No Brasil, Benedet e Carvalho (1996) caracterizando o leite de cabra em Santa Catarina obtiveram valores médios de proteína iguais a $3.280 \mathrm{mg} / \mathrm{dL}$; Fernandes (2002) avaliando as características do leite caprino no Estado de São Paulo obteve valores médios de proteína para a raça alpina iguais a $3.080 \mathrm{mg} / \mathrm{dL}$ e valores médios iguais a $3.080 \mathrm{mg} / \mathrm{dL}$ para a raça Saanen; também no Estado de São Paulo, Gomes et al. (2004) encontrou valores médios de proteína em cabras da raça Saanen iguais a $2.830 \mathrm{mg} / \mathrm{dL}$.

$\mathrm{Na}$ literatura compulsada, a proteína do soro de leite foi avaliada em estudos que abordaram frações isoladas, estudos amplos abordando todas as frações do soro lácteo foram conduzidos somente por Sant'ana (2004) e Raimondo, Miyiashiro e Birgel Junior (2009) em vacas.

Pesquisadores franceses, em diversos trabalhos, avaliaram a concentração das frações protéicas do soro lácteo de vacas holandesas durante a lactação plena através da técnica de imunodifusão radial. Rainard, Poutrel e Caffin (1982) obtiveram concentração de lactoferrina igual a $8,0 \mathrm{~m} / \mathrm{dL}$. Caffin, Poutrel e Rainard (1983) observaram que a concentração de $\lg _{1}$ foi igual a $46,0 \mathrm{mg} / \mathrm{dL}$ enquanto que Caffin e Poutrel (1988) observaram concentrações de $\mathrm{IgG}_{2}$ igual a $1,68 \mathrm{mg} / \mathrm{dL}$. Caffin, Poutrel e Rainard (1985) encontraram concentração de $\beta$-Lg igual a 467,0 $\mathrm{mg} / \mathrm{dL}$ e de $\alpha$-La igual a $147,0 \mathrm{mg} / \mathrm{dL}$.

Storry et al. (1983) avaliaram as proteínas do soro de leite de cabras e obtiveram as seguintes concentrações: proteína do soro entre 370 e $700 \mathrm{mg} / \mathrm{dL} ; \beta-\mathrm{Lg}$ entre 180 e $280 \mathrm{mg} / \mathrm{dL}$; $\alpha$-La entre 60 e $110 \mathrm{mg} / \mathrm{dL}$ e albumina séria entre 10 e 110 $\mathrm{mg} / \mathrm{dL}$. Sant'Ana (2004) avaliou o proteinograma de vacas da raça Holandesa e determinou os seguintes valores médios para a lactação plena: proteína do soro $1.071 \pm 133,3 \mathrm{mg} / \mathrm{dL}$; e para as frações protéicas do soro obtidas por eletroforese SDS-PAGE: lactoferrina - 63,95 $\pm 28,30 \mathrm{mg} / \mathrm{dL}$; albumina sérica - 70,70 $\pm 21,06$ $\mathrm{mg} / \mathrm{dL}$; imunoglobulina - 132,40 $\pm 37,41 \mathrm{mg} / \mathrm{dL} ; \beta-\mathrm{Lg}-580,52 \pm 95,10 \mathrm{mg} / \mathrm{dL} ; \alpha$-La$142,33 \pm 28,90 \mathrm{mg} / \mathrm{dL}$ e demais proteínas do soro $-63,36 \pm 40,71 \mathrm{mg} / \mathrm{dL}$.

Moatsou et al. (2008) na Grécia compararam os teores de $\beta$-Lg e $\alpha$-La, por cromatografia líquida, no leite de cabras locais $(335,0 \mathrm{mg} / \mathrm{dL}$ e $249 \mathrm{mg} / \mathrm{dL}$ respectivamente) com o leite de cabras de raças internacionais $(294,0 \mathrm{mg} / \mathrm{dL}$ e 
$225,0 \mathrm{mg} / \mathrm{dL}$ respectivamente). Raimondo, Miyiashiro e Birgel Junior (2009) encontraram no leite de vacas Jersey teores de proteína do soro iguais a $640 \pm 250$ $\mathrm{mg} / \mathrm{dL}$. Os autores estudaram também as concentrações das principais frações protéicas do soro lácteo e observaram concentrações médias iguais a: lactoferrina $40,0 \pm 20,0 \mathrm{mg} / \mathrm{dL}$, albumina sérica - 30,0 $\pm 20,0 \mathrm{mg} / \mathrm{dL}$, imunoglobulina cadeia pesada - 40,0 $\pm 20,0 \mathrm{mg} / \mathrm{dL}$ e cadeia leve $-80,0 \pm 60,0, \beta-\mathrm{Lg}-230,0 \pm 90,0 \mathrm{mg} / \mathrm{dL}$ e $\alpha$-La- $140,0 \pm 70,0 \mathrm{mg} / \mathrm{dL}$.

Os resultados da avaliação da influência da fase de lactação na concentração de proteína do leite de cabras foram controversos, independente da técnica utilizada na análise. Quiles et al. (1994) observaram um aumento na proteína total do leite cabras entre o $85^{\circ}$ e $210^{\circ}$ dias de lactação. A proteína total foi igual a $3.700 \mathrm{mg} / \mathrm{dL}$ no $85^{\circ}$ dia de lactação aumentando para $4.396 \mathrm{mg} / \mathrm{dL}$ no final do estudo 210 dias respectivamente. Zeng e Escobar (1995) observaram que os teores médios de proteína no leite de cabras tendem a diminuir até o quarto mês de lactação e voltam a aumentar até o final da lactação, sendo o valor máximo (3.480 mg/dL) observado no primeiro mês e o menor valor observado no quinto mês $(2.350 \mathrm{mg} / \mathrm{dL})$.

Fernandes (2002) observou em cabras acima dos 9 meses de lactação (3.300 $\mathrm{mg} / \mathrm{dL}$ ) valores maiores do que os observados em animais entre 1-3 meses (3.000 $\mathrm{mg} / \mathrm{dL})$, entre 4-6 meses $(3.110 \mathrm{mg} / \mathrm{dL})$ e entre $7-9$ meses de lactação (3.100 $\mathrm{mg} / \mathrm{dL}$ ). Gomes et al. (2004), observaram que os teores de proteína total no leite de cabras foram permaneceram estáveis durante a lactação. A autora encontrou valores médios iguais a $2.780 \mathrm{mg} / \mathrm{dL}$ no primeiro mês, iguais a $2.680 \mathrm{mg} / \mathrm{dL}$ no segundo mês, $2.880 \mathrm{mg} / \mathrm{dL}$ no terceiro mês e $2.930 \mathrm{mg} / \mathrm{dL}$ no quinto mês de lactação.

A concentração de proteína total no leite durante a lactação de cabras da raça Sarda foi estudada por Macciotta et al. (2005) que observaram teores máximos no $4^{\circ}$ e 5ํำ mês de lactação de cabras da raça Sarda $(4.140 \pm 50,0 \mathrm{mg} / \mathrm{dL}$ e $4.200 \pm 50,0$ $\mathrm{mg} / \mathrm{dL}$ respectivamente).

Mioč et al. (2008) observaram que a concentração de proteína total do leite de cabras aumenta com o avançar do estagio da lactação. Os autores encontraram concentrações de proteína iguais a $2.980 \pm 3,0 \mathrm{mg} / \mathrm{dL}$ no início da lactação (entre 10-90 dias), $3.060 \pm 4,0 \mathrm{mg} / \mathrm{dL}$ no meio $(91-180$ ) e $3.410 \pm 5,0 \mathrm{mg} / \mathrm{dL}$ (acima de 180 dias) no final da lactação. Assim como Strzałkowska et al. (2009) que também 
observaram um aumento na concentração protéica ao longo de seu estudo com concentrações iguais a $2.980 \pm 80,0 \mathrm{mg} / \mathrm{dL}$ aos 60 dias; $3.120 \pm 90,0 \mathrm{mg} / \mathrm{dL}$ aos 120 dias e $3.660 \pm 110,0 \mathrm{mg} / \mathrm{dL}$ aos 200 dias de lactação.

O número de lactações é um outro fator fisiológico que influencia o perfil protéico do leite. O metabolismo na glândula mamária durante a lactação de vacas primíparas quando comparadas com animais mais maduros é diferente. Nas primíparas os nutrientes são prioritários não somente para a lactação, mas também para o crescimento contínuo do animal (WATHES et al., 2007). Geralmente, vacas e cabras multíparas produzem mais leite, porém a persistência da lactação que é definida como a velocidade de declínio da produção diária, entre meses consecutivos, é inferior quando comparados com as primíparas (ZENG; ESCOBAR; POPHAM, 1997; MILLER et al., 2006; CARNICELLA et al., 2008; SAFAYI et al., 2010). Isso pode ser relacionado às diferenças no crescimento mamário e também na remodelação que ocorrem durante a lactação que difere entre cabras primíparas e multíparas. A população de células secretoras sobrevive por um período maior em cabras primíparas, demonstrando que ocorre um desenvolvimento progressivo do tecido mamário secretor e o sistema vascular das primíparas possui expressão maior de genes envolvidos na angiogênese (SAFAYl et al., 2010).

A influência do número de lactações nas concentrações de proteína total do leite de cabras foi estudada por diversos autores (KALA; PRAKASH, 1990; ZENG; ESCOBAR, 1995; PRASAD; SENGAR, 2002; CIAPPESONI et al., 2004; RODRIGUES et al., 2006; ZAHRADDEEN; BUTSWAT; MBAP, 2007; CARNICELLA et al., 2008). Os resultados obtidos na maioria dos referidos estudos demonstraram que não houve influência do número de lactações na concentração de proteína total. Prasad e Sengar (2002) apesar de não observarem influência da paridade nessas concentrações, o valor máximo foi obtido em cabras na segunda lactação (3.800 $\mathrm{mg} / \mathrm{dL}$ ). Ciappesoni et al. (2004) obtiveram os teores de proteínas em cabras que variaram entre $2.820,0$ e $2.830,0 \mathrm{mg} / \mathrm{dL}$ entre a primeira e quatro ou mais lactações.

Contudo Kala e Prakash (1990); Carnicella et al. (2008) e Mioč et al. (2008) observaram em cabras primíparas concentrações maiores de proteína, que diminuiu com o aumento do número de lactações. Macciotta et al. (2005) observaram um efeito significativo do número de lactações, pois cabras com 4 e 5 lactações apresentaram concentrações maiores de proteína no leite. Bhosale et al. (2009) observaram em cabras primíparas concentração de proteína total do leite igual a 
$3.217 \mathrm{mg} / \mathrm{dL}$ que aumenta chegando a concentrações iguais a $4.097 \mathrm{mg} / \mathrm{dL}$ em cabras com 4 lactações.

A avaliação da influencia da fase de lactação e do número de lactações nas frações protéicas do soro lácteo de cabras é escasso. Somente Quiles et al. (1994) que estudaram as proteínas do soro de leite de cabras ao longo da lactação determinando a proteína do soro e fracionando as protéicas por eletroforese SDSPAGE e de Hiss, Meyer e Sauerwein (2008) e Barth (2010) que avaliaram as concentrações de lactoferrina ao longo da lactação de cabras. Os demais estudos foram conduzidos em vacas e a maioria abordou apenas algumas frações, somente os estudos conduzidos por Sant'Ana (2004), Sant'Ana e Birgel (2007) e Raimondo, Miyiashiro e Birgel Junior (2009) avaliaram o proteinograma completo do soro lácteo de vacas.

Larson e Kendall (1957) em trabalho pioneiro avaliaram as proteínas do soro do leite bovino através da eletroforese em acetato de celulose. Os autores observaram que a fração $\beta-\mathrm{Lg}$ foi constante ao longo da lactação, a $\alpha$-La atingiu a produção máxima aos 30 dias e depois diminuiu com o evoluir da lactação, a concentração de imunoglobulina diminuiu no final da lactação enquanto que a concentração de albumina sérica oscilou pouco durante a lactação.

$\mathrm{Na}$ década de 80 um grupo de pesquisadores da França iniciou uma série de estudos avaliando os fatores fisiológicos que influenciavam as frações protéicas do soro lácteo de vacas Holandesas através da técnica de imunodifusão radial. Rainard, Poutrel e Caffin (1982) observaram que as concentrações de lactoferrina no leite de vacas não foram influenciadas pelo número de lactação dos animais e aumentaram com o evoluir da fase de lactação sendo menor em vacas com 30 dias de lactação (3,0 mg/dL) chegando a 15,0 mg/dL em vacas no final da lactação (270 dias). Poutrel, Caffin e Rainard (1983) avaliaram as concentrações de albumina sérica e observaram um aumento dessas concentrações em relação ao estágio de lactação com médias iguais a 17,3 mg/dL (30 dias), 18,8 mg/dL (150 dias) e 22,4 $\mathrm{mg} / \mathrm{dL}$ (270 dias). No mesmo trabalho os autores observaram que o número de lactações não influenciou os teores de albumina sérica no leite das vacas estudadas.

Caffin, Poutrel e Rainard (1985) observaram que as concentrações de $\beta$-Lg aumentaram com o evoluir da lactação, com médias iguais a 415,0 mg/dL (30 dias) $455,0 \mathrm{mg} / \mathrm{dL}$ (150 dias) e 536,0 mg/dL (270 dias). Enquanto que as concentrações de $\alpha$-La diminuíram com médias iguais a 154,0 mg/dL (30 dias), $151 \mathrm{mg} / \mathrm{dL}$ (150 
dias) e $136 \mathrm{mg} / \mathrm{dL}$ (270 dias). Segundo os autores o número de lactações influência o conteúdo de $\beta$-Lg e $\alpha$-La no leite de vacas. A concentração de $\alpha$-La diminuiu na terceira lactação $(118,0 \mathrm{mg} / \mathrm{dL})$ e voltou a aumentar, porém com menor concentração do que durante as duas primeiras lactações (163,0 mg/dL em primíparas e $156,0 \mathrm{mg} / \mathrm{dL}$ na $2^{\mathrm{a}}$ lactação). A concentração de $\beta$ - $\mathrm{Lg}$ aumentou na segunda lactação (508 mg/dL).

Os mesmos autores estudaram a influência da fase de lactação e número de lactações nos teores de imunoglobulinas IgG ${ }_{1}$ (CAFFIN; POUTREL; RAINARD, 1983) e IgG (CAFFIN; POUTREL, 1988). Caffin, Poutrel e Rainard (1983) observaram que a concentração de $\operatorname{lgG}_{1}$ durante as três primeiras lactações não foi afetada e, a variação foi pequena $(40,0-44,0 \mathrm{mg} / \mathrm{dL})$, após a terceira lactação, a concentração de $\operatorname{lgG}_{1}$ aumentou com grandes variações individuais, com teores iguais a $54 \mathrm{mg} / \mathrm{dL}$ em vacas com quatro lactações. Em relação à fase de lactação os autores observaram que as concentrações de $\operatorname{lgG}_{1}$ aumentaram com o evoluir da lactação e foram maiores $(60,0 \mathrm{mg} / \mathrm{dL})$ no final.

Caffin e Poutrel (1988) observaram que as concentrações de $\operatorname{lgG}_{2}$ foram menores nas duas primeiras lactações $(1,4 \mathrm{mg} / \mathrm{dL}$ e 1,3 mg/dL), vacas com mais de cinco lactações apresentaram concentrações iguais a 2,2 $\mathrm{mg} / \mathrm{dL}$. Segundo os autores a concentração média de $\operatorname{lgG}_{2}$ no leite foi maior no início da lactação (30 dias: $1,79 \mathrm{mg} / \mathrm{dL}$ ) do que no meio da lactação (150 dias: 1,48 mg/dL), provavelmente porque no início da lactação o transporte ativo de $\lg _{2}$, é particularmente importante durante o período de formação do colostro.

Quiles et al. (1994) observaram um aumento na proteína do soro e nas frações $\beta$-Lg e $\alpha$-La entre o 85 e 210 dias de lactação, e diminuição das outras frações ao longo do estudo. A proteína do soro igual $336 \mathrm{mg} / \mathrm{dL}$ no $85^{\circ}$ dia de lactação aumentou para $929,0 \mathrm{mg} / \mathrm{dL}$ no final do estudo (210 dias). As frações de $\beta$ Lg e $\alpha$-La foram iguais a $540,0 \mathrm{mg} / \mathrm{dL}$ e $123,0 \mathrm{mg} / \mathrm{dL}$ no início do estudo e 628 $\mathrm{mg} / \mathrm{dL}$ e $177,0 \mathrm{mg} / \mathrm{dL}$ em cabras com 210 dias de lactação. A fração denominada de "outras frações" foi igual a $179,0 \mathrm{mg} / \mathrm{dL}$ no início do estudo diminuindo gradativamente chegando a $122 \mathrm{mg} / \mathrm{dL}$ no final do período. Concluindo que o estágio de lactação teve um significativo efeito no fracionamento da proteína do leite de cabra particularmente evidente no início e no final do período de lactação.

Ostersen, Foldager e Hermansen (1997) estudaram o efeito do estágio de lactação nas proteínas do leite de vacas e observaram que os teores de proteína do 
soro são maiores no início e final da lactação, as concentrações mínimas foram observadas no meio da lactação quando as concentrações de caseína foram máximas. $O$ conteúdo de $\alpha$-La diminuiu durante a lactação, tanto em concentração absoluta como na proporção do total de proteínas do leite. Segundo os autores os resultados indicam que a queda foi causada principalmente por um teor ou síntese de $\alpha$-La reduzido ao longo da lactação. As mudanças no teor de $\beta$-Lg acompanham a concentração de proteína, porém atingiu concentração mínima no meio da lactação.

Sant'Ana (2004) observou influência do influência do número de lactações nas concentrações de proteína soro e de lactoferrina no leite de vacas Holandesas. A concentração de albumina sérica nas vacas com duas ou três lactações $(61,75 \pm$ $16,80 \mathrm{mg} / \mathrm{dL})$ foi menor do que primíparas $(75,72 \pm 19,61 \mathrm{mg} / \mathrm{dL})$ e 4 ou mais lactações $(73,60 \pm 23,95 \mathrm{mg} / \mathrm{dL})$. Em relação à imunoglobulina, valores menores, também, foram obtidos nas vacas de $2^{\mathrm{a}}$ ou $3^{\mathrm{a}}$ lactações $(117,96 \pm 34,75 \mathrm{mg} / \mathrm{dL}$ ); valor médio intermediário em primíparas $(134,53 \pm 35,92 \mathrm{mg} / \mathrm{dL})$ e, o maior valor foi observado em animais com 4 ou mais lactações $(143,60 \pm 38,11 \mathrm{mg} / \mathrm{dL})$. A fração de $\beta$-Lg em animais com quatro ou mais lactações, foi menor (545,94 $\pm 70,35 \mathrm{mg} / \mathrm{dL})$ do que em primíparas, assim como em duas ou três lactações (respectivamente: $595,51 \pm 104,52$ e $599,93 \pm 99,28 \mathrm{mg} / \mathrm{dL}$ ). O menor valor de $\alpha$-La foi observado em vacas de duas ou três lactações $(135,05 \pm 27,51 \mathrm{mg} / \mathrm{dL})$, sendo o valor intermediário observado nos animais com quatro ou mais lactações $(139,90 \pm 29,44 \mathrm{mg} / \mathrm{dL})$ e, o maior valor (150,78 $\pm 28,22 \mathrm{mg} / \mathrm{dL})$ obtido em vacas primíparas.

Sant'Ana e Birgel (2007) estudaram a influência do estagio de lactação nas proteínas do leite de vacas. A proteína do soro lácteo foi maior na fase colostral (respectivamente: $1.576,88 \pm 797,10 \mathrm{mg} / \mathrm{dL} ; 1.030,68 \pm 123,78 \mathrm{mg} / \mathrm{dL} ; 1.084,21 \pm$ $139,33 \mathrm{mg} / \mathrm{dL}$ e; $1.156,00 \pm 100,41 \mathrm{mg} / \mathrm{dL}$ ), aumento esse atribuído as protéicas séricas do leite, como: imunoglobulinas $(366,71 \pm 278,18 \mathrm{mg} / \mathrm{dL} ; 129,77 \pm 31,65$ $\mathrm{mg} / \mathrm{dL} ; 139,47 \pm 32,05 \mathrm{mg} / \mathrm{dL}$ e, 122,23 $\pm 59,43 \mathrm{mg} / \mathrm{dL}$ ) e outras proteínas do soro lácteo $(129,01 \pm 135,24 \mathrm{mg} / \mathrm{dL} ; 59,11 \pm 46,73 \mathrm{mg} / \mathrm{dL} ; 64,95 \pm 35,88 \mathrm{mg} / \mathrm{dL}$ e, 71,85 \pm $33,37 \mathrm{mg} / \mathrm{dL}$ ). Os teores de albumina sérica e lactoferrina não variaram ao longo do estudo. A $\beta$ - Lg, foi maior na primeira e na última fase da lactação $(726,10 \pm 291,20$ $\mathrm{mg} / \mathrm{dL} ; 547,55 \pm 70,63 \mathrm{mg} / \mathrm{dL} ; 584,09 \pm 99,98 \mathrm{mg} / \mathrm{dL}$ e; $668,24 \pm 92,60 \mathrm{mg} / \mathrm{dL})$. A 
fração $\alpha$-La apresentou pequena variação no decorrer da lactação $(159,21 \pm 39,38$ $\mathrm{mg} / \mathrm{dL} ; 150,64 \pm 25,42 \mathrm{mg} / \mathrm{dL} ; 131,89 \pm 27,79 \mathrm{mg} / \mathrm{dL} \mathrm{e} ; 144,39 \pm 34,38 \mathrm{mg} / \mathrm{dL})$.

Cheng et al. (2008) avaliaram a concentração de lactoferrina no leite bovino através do método de ELISA durante o pico (21 a 100 dias); meio (101 a 200 dias) e final da lactação (201 dias) e observaram concentrações maiores no final da lactação. Os autores observaram que a concentração de lactoferrina no leite não diferiu em relação ao número de lactações. No entanto, as concentrações tenderam a ser maiores em vacas com 3, 4 e mais de 5 lactações do que para vacas com 1 ou 2 lactações.

As concentrações de lactoferrina no leite de cabras foram analisadas por ELISA desenvolvido para lactoferrina de caprinos por Hiss, Meyer e Sauerwein (2008). Máximas concentrações foram observadas nas amostras do colostro (387 \pm $6,9 \mathrm{mg} / \mathrm{dL}$ ). Na semana seguinte, menos de $20 \%$ destas concentrações foram observadas $(6,2 \pm 2,5 \mathrm{mg} / \mathrm{dL})$ e, posteriormente, na $32^{\mathrm{a}}$ semana a concentração média semanal variou entre 1,0 e $2,8 \mathrm{mg} / \mathrm{dL}$. Perto do final da lactação, na $33^{\mathrm{a}}$ semana, a concentração começou a aumentar atingindo o maior valor na $44^{\circ}$ semana $(10,7 \pm 1,9 \mathrm{mg} / \mathrm{dL})$.

Raimondo, Miyiashiro e Birgel Junior (2009) estudaram a influência da fase de lactação na concentração de proteína do soro lácteo de vacas da raça Jersey e observou no terço inicial $(810 \pm 150 \mathrm{mg} / \mathrm{dL})$ e no terço médio da lactação $(730 \pm 220$ $\mathrm{mg} / \mathrm{dL}$ ) teores de proteína maiores do que no terço final da lactação (380 \pm 160 $\mathrm{mg} / \mathrm{dL}$ ). Os autores também fracionaram as proteínas do soro através da técnica de eletroforese SDS-PAGE e observaram diminuição nas concentrações de $\beta$-Lg (terço inicial 280,0 $\pm 60 \mathrm{mg} / \mathrm{dL}$; médio $260,0 \pm 60 \mathrm{mg} / \mathrm{dL}$ e final 150,0 $\pm 70,0 \mathrm{mg} / \mathrm{dL}$ ), $\alpha$-La (terço inicial 190,0 \pm 40,0 mg/dL; médio 150,0 \pm 40,0 mg/dL e final 70,0 $\pm 50,0$ $\mathrm{mg} / \mathrm{dL}$ ), imunoglobulinas (terço inicial - Ig pesada - 50,0 $\pm 20,0 \mathrm{mg} / \mathrm{dL}$; Ig leve $-90,0$ $\pm 30,0 \mathrm{mg} / \mathrm{dL}$, médio lg pesada $-50,0 \pm 30,0 \mathrm{mg} / \mathrm{dL}$; Ig leve $-110,0 \pm 80,0 \mathrm{mg} / \mathrm{dL}$ e final Ig pesada - 30,0 $\pm 20,0 \mathrm{mg} / \mathrm{dL}$; Ig leve $-20,0 \pm 20,0 \mathrm{mg} / \mathrm{dL}$ ), lactoferrina (terço inicial $60,0 \pm 20,0 \mathrm{mg} / \mathrm{dL}$, médio $50,0 \pm 20,0 \mathrm{mg} / \mathrm{dL}$ e final $30,0 \pm 20,0 \mathrm{mg} / \mathrm{dL})$ e albumina (terço inicial $30,0 \pm 10,0 \mathrm{mg} / \mathrm{dL}$, médio $40,0 \pm 20,0 \mathrm{mg} / \mathrm{dL}$ e terço final 10,0 $\pm 10,0 \mathrm{mg} / \mathrm{dL}$ ) durante a lactação. No mesmo estudo foi concluído que as frações de $\beta$-Lg e $\alpha$-La são as principais proteínas do soro (64,51 \%) as demais proteínas dentre elas as imunoglobulinas representaram $20,91 \%$, enquanto que os 
percentuais de lactoferrina e albumina foram respectivamente $6,97 \%$ e $5,23 \%$ do total da proteína do soro lácteo.

Recentemente Barth et al. (2010) observou que os teores de lactoferrina no soro lácteo de cabras primíparas é menor quando comparado com o teor encontrado em cabras multíparas.

\subsection{Influência do isolamento bacteriano no proteinograma do leite de cabras}

A mamite caprina, assim como a bovina, gera graves prejuízos econômicos devido ao descarte do leite, custos com medicamentos e assistência veterinária, aumento da mão-de-obra, redução da qualidade e quantidade do leite e seus subprodutos. Dentre os agentes etiológicos bacterianos identificados na mastite caprina, a maioria é similar aos encontrados na espécie bovina, entre eles Staphylococcus coagulase positiva (Staphylococcus aureus) e negativa ( $S$. epidermidis, $S$. chromogenes e $S$. simulans, $S$. caprae e $S$. agalactiae), Streptococcus spp, Corynebacterium spp, Escherichia coli, Micrococcus spp, Pasteurella spp (CONTRERAS et al., 2003; LANGONI; DOMINGUES; BALDINI, 2006; SCHMIDT et al., 2009; NEVES et al., 2010).

Urech, Puhan e Schällibaum (1999) observaram que o teor de proteína total em todas as frações de ordenha aumentou no leite de quartos com mastite em vacas. Segundo os autores o aumento da proporção de proteínas associadas com a resposta inflamatória do úbere (lactoferrina, imunoglobulinas e albumina sérica) compensou a significativa diminuição de caseína em realção a proteína total.

Segundo Birgel Junior (2006) a determinação do teor de proteína total do leite foi, inicialmente, considerada de pouca valia, porém os resultados obtidos por Sant'Ana (2004), demonstraram a importância da determinação do teor de proteína total do leite e seu fracionamento como parâmetro para o diagnóstico das mamites. Pois, nesses casos patológicos, comprovou-se, que o aumento dos teores de proteína total com diminuição dos teores de caseína e aumento dos teores de proteínas séricas no soro lácteo representava sintoma de alteração da glândula mamária. 
Recentemente Forsbäck et al. (2010) confirmaram a importância do estudo da proteína do soro lácteo. Os autores avaliaram o leite bovino com altas contagens de células somáticas e isolamento bacteriano e observaram que não houve alteração na concentração de proteína total apesar da diminuição nos teores de caseína, segundo os autores a falta de alteração na proteína total do leite foi compensada pelo aumento das proteínas do soro lácteo e concluíram que usar somente o conteúdo de proteína total como marcador de qualidade do leite é, portanto, questionável, ao passo que a determinação do teor de proteínas de soro de leite, além de proteína total, seria uma validação mais correta da qualidade protéica do leite.

Leitner, Merin e Silanikove (2004) avaliaram as alterações nos constituintes do leite de cabras com isolamento bacteriano e observaram um aumento nas concentrações de proteína total $(3.500 \mathrm{mg} / \mathrm{dL})$, proteína do soro lácteo $(680,0$ $\mathrm{mg} / \mathrm{dL})$ e albumina no soro lácteo $(47,18 \mathrm{mg} / \mathrm{dL})$ nas amostras com isolamento bacteriano comparadas com amostras sem isolamento bacteriano aonde foi observado às seguintes concentrações: proteína total $(3.420 \mathrm{mg} / \mathrm{dL})$, proteína do soro lácteo $(610,0 \mathrm{mg} / \mathrm{dL})$ e albumina no soro lácteo $(28,0 \mathrm{mg} / \mathrm{dL})$.

Segundo Barth et al. (2010) a avaliação da saúde do úbere em caprinos ainda é difícil quando comparado com as vacas, devido às limitações da contagem de células somáticas (CCS) como indicador de infecção intramamária, os autores avaliaram os teores de lactoferrina no leite caprino com e sem isolamento bacteriano, com a finalidade de usar essa proteína como indicador da saúde da glândula mamária nessa espécie. Os resultados da referida pesquisa demostraram que o leite com isolamento bacteriano apresentou concentrações elevadas de lactoferrina em relação as amostras sem isolamento.

A lactoferrina é reconhecida como uma proteína bacteriostática e bactericida, propriedades atribuídas à sua capacidade de quelante de ferro e capacidade de se ligar à superfície bacteriana (CHANETON et al., 2008). Estudos anteriores também avaliaram as concentrações de lactoferrina no soro lácteo de cabras e vacas em relação ao isolamento bacteriano no leite. De acordo com Kawai et al. (1999) a concentração de lactoferrina no leite de vacas aumenta durante a infecção intramamária e depende da bactéria causadora e da gravidade da infecção. No leite normal a concentração de lactoferrina é 2,0 a 20,0 mg/dL e no leite mastítico, 30,0 a $230 \mathrm{mg} / \mathrm{dL}$. 
Chen, Chen e Mao (2004) avaliaram a influência do isolamento bacteriano na concentração de lactoferrina no leite de cabras através do método de ELISA. Primeiramente os autores utilizaram leite colhido de tanque classificado de acordo com o tempo de redução de azul de metileno e observaram que quanto menor o tempo de redução de azul de metileno maior as concentrações de lactoferrina, leite classificado como de alta qualidade continham $16,7 \mathrm{mg} / \mathrm{dL}$, qualidade normal 21,8 $\mathrm{mg} / \mathrm{dL}$, e baixa qualidade $30,4 \mathrm{mg} / \mathrm{dL}$ e leite classificado como matite com redução de azul de metileno entre 3 e 4,5 horas apresentaram concentrações de lactoferrina iguais a $58,7 \mathrm{mg} / \mathrm{dL}$. Os autores avaliaram também as concentrações de lactoferrina no leite de cabras inoculadas com Staphylococcus aureus, metade do ubere de três cabras foram inoculadas e a outra metade foi usada como controle negativo. As médias de lactoferrina no leite infectado aumentou gradativamente a partir de 0 hora de inoculação até 72 horas após, iniciando com 1,0 mg/dL chegando a 100, $0 \mathrm{mg} / \mathrm{dL}$ enquanto que o leite colhido da metade não infectada variou entre 1,0 e 3,0 mg/dL. Os autores concluíram que as concentrações de lactoferrina no leite podem ser úteis para determinar o estatus de infecção da glândula mamária de cabras.

Chaneton et al. (2008) estudaram a relação entre a lactoferrina no leite e o agente etiológico da mastite bovina e observaram que quartos infectados apresentaram concentração de lactoferrina mais alta que quartos negativos e em quartos com mastite as concentrações foram ainda maiores. Segundo os autores essa relação sugeriu resposta lactoferrina-dependente, em relação à bactéria isolada, mesmo quando na ausencia de um processo inflamatório na glândula mamária. Quartos positivos para Streptococcus uberis apresentaram maiores concentrações de lactoferrina que quartos negativos, enquanto que outras bactérias, como Staphylococcus aureus, Sthaphylococcus coagulase negativo e Streptococcus dysgalactiae não parecem estar associadas a um aumento na concentração de lactoferrina. No mesmo estudo, um experimentos in vitro de infecção foi realizado por desafio de cultura primária de células mamárias de bovinos com suspensão de Streptococcus uberis. A análise da imunofluorescência demonstrou que células da glândula mamária são capazes de sintetizar lactoferrina e essa produção foi maior na suspensão de Streptococcus uberis. Os autores avaliaram ainda a suscetibilidade da bactéria, e observaram que o crescimento de Escherichia coli e Staph. aureus foi inibido pela lactoferrina, enquanto que o crescimento do Strep. uberis não foi afetado, concluindo que os agentes bacterianos que provocam maior resposta da 
lactoferrina se adaptaram a essas condições tornando-se resistentes à atividade antibacteriana desta proteína.

Hyvönen et al. (2009) estudaram a adesão, invasão e replicação intracelular de 22 linhagens de Staphylococcus coagulase-negativo isoladas de bovinos com mastite e os efeitos da lactoferrina bovina sobre a internalização através de um modelo in vitro de celulas do epitelio mamário bovino. A lactoferrina diminuiu significativamente a replicação intracelular $e$ as taxas de replicação do Staphylococcus. Forte correlação entre a adesão e invasão, bem como entre a replicação e a taxa de replicação, foi encontrado no estudo. Nas análises de sensibilidade in vitro e internalização, o papel da lactoferrina foi principalmente bacteriostático, provavelmente pelo quelante de ferro e pela ligação a receptores específicos na superfície da célula bacteriana. Forsbäck et al. (2010) observaram que os teores de lactoferrina foram maiores no soro lácteo de vacas com alta contagem de células somáticas e isolamento bacteriano.

Apesar da comprovada importância da determinação das proteínas do soro lácteo como auxílio na avaliação da saúde da glândula mamária, apenas a lactoferrina foi objetivo de estudos recentes, a avaliação da proteína do soro lácteo assim como das demais frações protéicas do soro lácteo ainda é escasso em vacas e em cabras é inexistente.

$\mathrm{Na}$ década de 80 um grupo de pesquisadores da França realizou uma série de estudos dos fatores patológicos que influenciam as frações protéicas do soro lácteo de vacas holandesas através da técnica de imunodifusão radial. Caffin, Poutrel e Rainard (1983) observaram que quartos mamários de vacas com isolamento de Corynebacterium bovis, as concentrações $\operatorname{lgG}_{1}$ no soro lácteo amostras de soro (82,0 mg/dL) são altas. Quartos infectados por estreptococos não afetou a concentração de $\lg _{1}$ no leite. Quartos infectados com Staphylococcus aureus aumentou a correlação entre a $\operatorname{lgG}_{1}$, e as concentrações de albumina no leite. Segundo os autores este aumento provavelmente é devido a um processo inflamatório, pois o coeficiente de correlação entre as concentrações de albumina sérica e $\lg \mathrm{G}_{1}$ é considerado um índice de resposta inflamatória. Albumina sérica é um marcador para estimar a transferência de proteínas do sangue para o leite, principalmente as imunoglobulinas (LARSON; HEARY JR.; DEVERY, 1980)

Caffin, Poutrel e Rainard (1985) observaram diminuição nos teores de $\alpha$ lactoalbumina ( $\alpha-\mathrm{La}$ ) no leite de vacas com isolamento bacteriano, enquanto que as 
concentrações de $\beta$-lactoglobulina ( $\beta$ - $L g$ ) não foram influenciadas pelo isolamento bacteriano. Caffin e Poutrel (1988) observaram que glândulas mamárias com isolamento de estafilococos coagulase-negativo não influenciou o teor de $\lg G_{2}$ no leite de vacas $(1,92 \pm 0,85 \mathrm{mg} / \mathrm{dL})$, enquanto que nos quartos com Corynebacterium bovis, houve um aumento de $\mathrm{IgG}_{2}$ no leite $(2,6 \pm 1,16 \mathrm{mg} / \mathrm{dL})$, assim como em quartos com Staphylococcus aureus (3,74 $\pm 1,7 \mathrm{mg} / \mathrm{mL})$.

$\mathrm{Na}$ literatura compulsada somente o trabalho de Sant'Ana (2004) avaliou a influência do isolamento bacteriano no proteinograma de vaca holandesas através da técnica de eletroforese em gel de poliacrilamida na presença de dodecil sulfato de sódio (SDS-PAGE). A autora observou que não houve influência do isolamento bacteriano nas concentrações de proteína total, proteína do soro lácteo e frações protéicas, com exceção a fração $\alpha$-La foi menor em amostras com isolamento bacteriano (139,96 $\pm 37,15 \mathrm{mg} / \mathrm{dL})$ quando comparadas com amostras negativas no exame microbiológico $(152,82 \pm 38,28 \mathrm{mg} / \mathrm{dL})$. Comparando amostras de quartos com mamite e quartos mamários sadios a autora observou um aumento da proteína total, proteína do soro, lactoferrina, albumina e imunoglobulinas, exceção feita as principais frações do soro lácteo $\alpha$-La e $\beta$-Lg que não foram influenciadas pela mamite.

\subsection{Influência do vírus da artrite-encefalite caprina no proteinograma do leite de cabras}

A artrite encefalite caprina (CAE) que é uma doença infecciosa causa pelo retrovírus pertencente a subfamília Lentivirinae que acomete caprinos de todas as raças e idades, de natureza crônica, suas principais manifestações são a artrite em caprinos adultos a leucoencefalomielite em caprinos jovens, além de ser responsável por mamite indurativa nas cabras infectadas (LARA, 2002).

No Brasil, o primeiro registro sorológico da CAE (MOOJE et al., 1986) e o primeiro isolamento do vírus (HÖTZEL et al., 1993) foram realizados no Rio Grande do Sul. As prevalências encontradas variaram de $0,73 \%$ para $43,0 \%$ em pesquisas nos seguintes Estados: Pernambuco (SARAIVA NETO et al., 1995), Ceará (PINHEIRO; GOUVEIA; ALVES, 2001), São Paulo (LEITE et al., 2004), Paraíba 
(BANDEIRA et al., 2009), Rio Grande do Norte (SILVA et al., 2005), Bahia (OLIVEIRA et al., 2006), Piauí (SAMPAIO JÚNIOR, 2007), Rio de Janeiro (MOREIRA; OELEMANN; LILENBAUM, 2007), e Tocantins (SOBRINHO et al., 2010).

$\mathrm{Na}$ glândula mamária de cabras infectadas Lara (2002) descreveu o endurecimento gradativo com a presença de vários nódulos de consistência dura, que confluem para determinar um endurecimento difuso do parênquima mamário, resultando em assimetria das metades do úbere. No Brasil, o endurecimento gradativo da mama (mamite indurativa), em cabras infectadas pelo Vírus da Artriteencefalite caprina (CAEV) pode ser diagnosticado entre 4,0 \% e 19,67\% dos animais infectados conforme demonstrou os estudos de Lara (2002); Lara et al. (2005) e Birgel Junior et al. (2007).

Em pesquisa realizada nas condições brasileiras de manejo, Bohland e D'Angelino (2005) verificaram que a produção leiteira nas cabras infectadas pelo CAEV era $21,5 \%$ menor do que nos animais não infectados e que cabras infectadas apresentavam lactações mais curtas, sendo a sua duração, em média, 37 dias menor do que a observada em animais não infectados.

Segundo Gregory et al. (2009) a substituição do parênquima da glândula por tecido conjuntivo e fibrose observada no exame histopatológico explica a diminuição na produção de leite e a qualidade do leite produzido pelos animais infectados pelo vírus. A fibrose no parênquima mamário em cabras inoculadas com o CAEV por via intra-mamária foi anteriormente citada por Lerondelle et al. (1995), segundo os autores a glândula mamária das cabras abatidas entre 3 e 5 dias após a inoculação do vírus, tinham característica histológica de lesões de hiperplasia linfóide folicular ao redor dos ductos lactíferos, infiltração intersticial de células mononucleares, e fibrose.

Afora a influência da infecção do vírus da CAE na produção de leite das cabras, as características físico-químicas e celulares do leite também são influenciadas. Birgel Junior et al. (2007), observaram valores de eletrocondutividade, cloretos e a CCS foram maiores enquanto que os valores de lactose foram menores nas cabras infectadas com ou sem sinais de endurecimento difuso da mama. Os valores de proteína, gordura e sólidos totais foram menores somente no grupo de cabras infectadas com endurecimento difuso da mama e os valores do $\mathrm{pH}$ não 
sofreram influência. Segundo os autores essas alterações são evidências que a mama é precocemente afetada por esta infecção.

Almeida (2009) observou em cabras soropositivas para o CAEV teores menores de lactose e cloreto, enquanto que os teores de caseína não foram influenciados pela infecção.

As alterações nas constituições físico-químicas no leite de cabras sororeagentes positivas para o vírus da CAE podem ser explicadas pelo comprometimento do tecido mamário anteriormente relatado por Lerondelle et al. (1995) e mais recentemente confirmado por Gregory et al. (2009).

Processos infecciosos, como as mamites bacterianas, foram responsáveis por alterações no proteinograma do leite, pois apesar de não ser observado alterações na proteína total do leite estudos demomonstraram a importancia da determinação da proteína do soro lácteo assim como de suas frações, pois essa falta de alteração na proteína total do leite foi compensada pelo aumento das proteínas do soro lácteo conforme descrito por Forsbäck et al. (2010). Além disso, anteriormente Sant'Ana (2004) comprovou que o aumento dos teores de proteína total com diminuição dos teores de caseína e aumento dos teores de proteínas séricas no soro lácteo representava sintoma de alteração da glândula mamária. 
Materiais e métodos

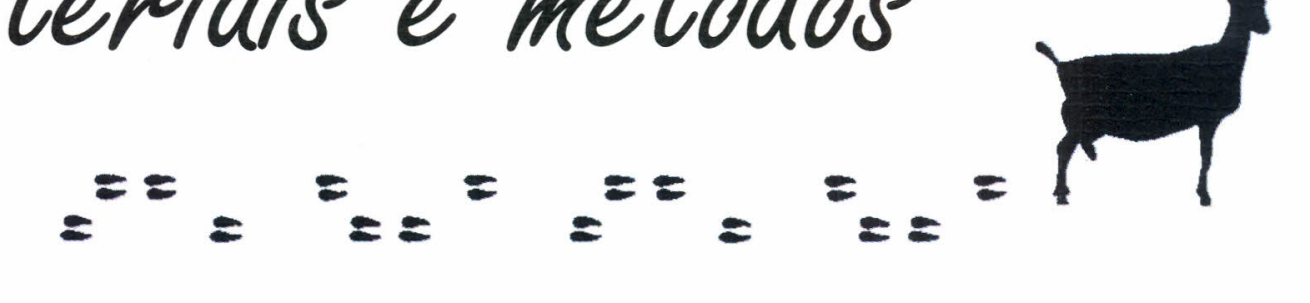




\section{MATERIAIS E MÉTODOS}

O presente estudo foi realizado em duas etapas distintas divididas em cinco estudos de acordo com as influencias avaliadas, para tanto foram colhidas 750 amostras provenientes de 187 cabras da raça Saanen das quais foram utilizadas 545 amostras provenientes de 185 cabras da raça Saanen.

Primeira etapa composta por dois estudos: estudo 1: Avaliação da influência do processo de secagem da glândula mamária no proteinograma da secreção láctea de cabras; estudo 2: Avaliação da influência da fase colostral e do primeiro mês de lactação no proteinograma da secreção láctea de cabras, foi conduzida com o acompanhamento de dois grupos de animais pré-selecionados para cada influência com amostras pareadas com a finalidade de concentrar os momentos de colheita.

Segunda etapa conduzida em propriedades particulares pré-selecionadas com colheita aleatória de amostras de leite de cabras foi composta por três estudos: estudo 3: Valores de referência e avaliação das proteínas do soro lácteo de cabras durante a lactação plena; estudo 4: Avaliação da influência do isolamento bacteriano nas proteínas do leite de cabras e estudo 5: Avaliação da influência da infecção pelo Vírus da Artrite-encefalite caprina (CAE) nas proteínas do leite de cabras.

ESTUDOS 1 e 2 - conduzidos na Clínica de bovinos e pequenos ruminantes do Departamento de Clínica Médica da FMVZ-USP situado na cidade de São Paulo (latitude $23^{\circ} 32^{\prime}$ 51', longitude 46 $38^{\circ}$ ' 10", a 760m de altitude). As cabras foram selecionadas através do exame clínico e do histórico, não sendo utilizados animais que apresentaram alterações das características macroscópicas do leite, como presença de grumos ou alterações de cor detectada na prova do fundo escuro e alterações na palpação da glândula mamária, realizada após a ordenha, conforme as recomendações de Birgel (2004). Todas as cabras foram mantidas em baias com solário e alimentadas com feno de coast-cross, fornecido no período da manhã e da tarde, ração peletizada com 14\% de proteína bruta fornecida pela manhã e água ad libitum. Semanalmente, era fornecido aos animais sal mineral de bovinos. 


\subsection{Avaliação da influência do processo de secagem da glândula mamária no proteinograma da secreção láctea de cabras.}

Foram colhidas 104 amostras de secreção láctea de oito cabras da raça Saanen acompanhadas durante 30 dias do período seco. As cabras foram secas de forma abrupta, ou seja, com interrupção da ordenha sem a aplicação de antibiótico intra-mamário, sendo utilizadas somente a secreção láctea que não apresentou qualquer distúrbio macroscópico e exame microbiológico negativo, ao todo foram descartadas 3 glândulas mamárias ao longo do estudo (Tabela 1). Após a colheita das amostras as cabras não foram ordenhadas a fim de promover o devido processo de involução da glândula mamária.

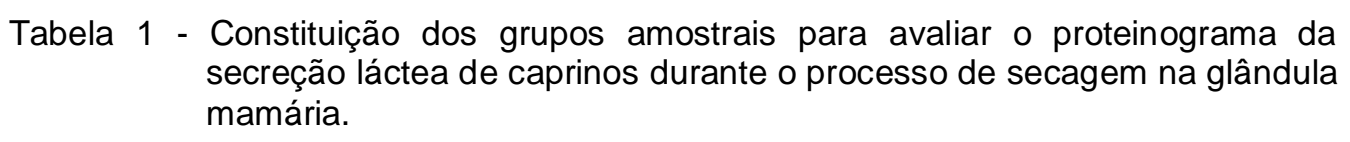

Tabela 1 - Constituição dos grupos amostrais para avaliar o proteinograma da secreção láctea de caprinos durante o processo de secagem na glândula mamária.

\begin{tabular}{|c|c|c|c|}
\hline \multicolumn{3}{|c|}{ Momentos de Colheita } & $\begin{array}{c}\text { Número de glândulas } \\
\text { Avaliadas }\end{array}$ \\
\hline 1 & & Última Ordenha & 13 \\
\hline 2 & & 1ํ Dia da Secagem & 13 \\
\hline 3 & $\begin{array}{ll}\infty & -\pi \\
0 & \stackrel{\pi}{\varepsilon}\end{array}$ & $3^{\circ}$ Dia da Secagem & 13 \\
\hline 4 & \& & $5^{\circ}$ Dia da Secagem & 13 \\
\hline 5 & ¿ & $7^{\circ}$ Dia da Secagem & 13 \\
\hline 6 & $\frac{\bar{\alpha}}{0} \frac{\sqrt{\pi}}{0}$ & $10^{\circ}$ Dia da Secagem & 13 \\
\hline 7 & $\stackrel{0}{=}$ & $15^{\circ}$ Dia da Secagem & 13 \\
\hline 8 & 产 & 30 Dia da Secagem & 13 \\
\hline
\end{tabular}

\subsection{Avaliação da influência da fase colostral e do primeiro mês de lactação no proteinograma da secreção láctea de cabras.}

Foram utilizadas sete cabras da raça Saanen, das quais foram colhidas 110 amostras em 10 momentos diferentes e que apresentaram exame microbiológico negativo ao longo do primeiro mês de lactação (Tabela 2). Três glândulas mamárias foram retiradas do estudo, pois, a secreção colhida foi positiva no exame microbiológico, ou seja, apresentou isolamento bacteriano em algum dos momentos. 
Tabela 2 - Constituição dos grupos amostrais para avaliar o proteinograma da secreção láctea de caprinos durante o primeiro mês de lactação. São Paulo 2008

\begin{tabular}{|c|c|c|c|}
\hline \multicolumn{3}{|c|}{ Momentos de Colheita } & Número de glândulas Avaliadas \\
\hline 1 & 0 & $1 / 2$ dia (0 a 12 horas) & 11 \\
\hline 2 & "ृ్లె & $1^{\circ}$ dia (12 a 24 horas) & 11 \\
\hline 3 & $\underline{\underline{\mathbb{U}}}$ & $2^{\circ} \mathrm{dia}$ & 11 \\
\hline 4 & $\frac{1}{0}$ & $3^{\circ}$ dia & 11 \\
\hline 5 & 迅 & $5^{\circ}$ dia & 11 \\
\hline 6 & $\cdot \frac{\circ}{\overline{0}}$ & $7^{0}$ dia & 11 \\
\hline 7 & 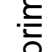 & $10 \cong \mathrm{dia}$ & 11 \\
\hline 8 & O & $15^{\circ} \mathrm{dia}$ & 11 \\
\hline 9 & 官 & $20^{\circ} \mathrm{dia}$ & 11 \\
\hline 10 & ق & $30^{\circ}$ dia & 11 \\
\hline
\end{tabular}

Com a finalidade de concentrar os partos para facilitar as colheitas de leite no período inicial da lactação, as cabras foram submetidas à sincronização do cio com monta natural assistida conforme o protocolo proposto por Traldi (1985): Dia 1: colocação do dispositivo intravaginal de progesterona $(C I D R \circledast$, Pfizer Saúde Animal); Dia 9: Aplicação intramuscular de 250UI de Gonadotrofina Coriônica Eqüina (Novormon $\circledast$ Schering Plogh Coopers) e de $0,25 \mathrm{ml}$ de Gloprostenol (Ciosin $\circledast$ Schering Plogh Coopers); Dia11: Retirada do CIDR® e colocação das fêmeas com o macho; Dia16: Separação de machos e fêmeas

A prenhez dos animais foi confirmada através do exame ultrassonográfico realizado 15 e 30 dias após a separação das fêmeas e machos e a data possível do parto foi estimada. Durante o período do estudo as cabras eram separadas dos cabritos na noite anterior e logo após a colheita eram ordenhadas e o colostro e/ou leite utilizado para amamentar os cabritos.

ESTUDOS 3, 4, e 5 - foram realizados em quatro capris comerciais criadores de cabras da raça Saanen, sendo três localizadas em municípios na região do Vale do Paraíba; Jacareí (Latitude: 23ํㅜ 18' 19" S, Longitude: 45ํ57' 57" O; altitude de 567 metros, localizada a $84 \mathrm{Km}$ de São Paulo); Caçapava (Latitude: 23 $06^{\prime}$ 03" S, Longitude: 45o 42' 25" O, altitude de 560 metros a $117 \mathrm{Km}$ de São Paulo); Guaratinguetá (Latitude: 220 48' 59" S; Longitude: 45 11' 33" O, altitude de 530 metros, localizada a 180 Km de São Paulo) e uma em Ibiúna (Latitude: 23o 39' 23" S, Longitude: 47ำ13' 21" O, altitude de 996 metros, localizada a 50 Km de São Paulo). 
As quatro propriedades adotavam o sistema de criação intensivo, em cabanhas, sendo que a de Caçapava e Guaratinguetá com piso suspenso do tipo ripado, e a de lbiúna e Jacareí com piso de concreto. A alimentação das cabras fornecida no cocho era baseada em volumoso picado, silagem de milho e ração comercial com suplementação de sal mineral e água ad libitum. O sistema de ordenha era mecânico realizado em salas de ordenha nas propriedades de Ibiúna, Caçapava e Guaratinguetá, na propriedade de Jacareí a ordenha mecânica era realizada em plataforma de madeira localizada em local limpo e arejado ao lado das instalações do galpão.

Primeiramente iniciou-se um estudo epidemiológico para o vírus da artrite e encefalite caprina (CAE) nas propriedades. Para tanto foram colhidas amostras de sangue dos caprinos por punção da veia jugular externa, utilizando-se Sistema Vacutainer ${ }^{\circledR}$ em tubos secos, sem anticoagulante, para obtenção de soro sanguíneo. A pesquisa de anticorpos séricos antivírus da CAE, foi realizada empregando-se a prova sorológica de imunodifusão em gel de ágar (IDGA), segundo técnica preconizada por Cutlip et al. (1977), utilizando-se Kit comercial de imunodifusão em gel de Agar (IDGA) para diagnóstico de CAE da Biovetech Indústria e Comércio de Produtos Biotecnológicos Ltda.

O gel de agarose (pertencente ao kit) foi aquecido em microondas até total dissolução e com a utilização de pipeta de vidro foi distribuído $14 \mathrm{~mL}$ de gel de agarose em placa de Petri de $90 \mathrm{~mm}$ de diâmetro. Após a completa solidificação o gel foi perfurado com um cortador de metal específico, em forma de roseta, contendo sete poços de $4 \mathrm{~mm}$ de diâmetro e $3 \mathrm{~mm}$ de distância entre as bordas, sendo uma central e seis periféricas equidistantes. Os reagentes (antígeno antiCAEV e soro controle positivo) foram homogeneizados e distribuídos de acordo com a sequência: nas seis cavidades periféricas, de maneira alternada, $20 \mu \mathrm{L}$ do soro da amostra teste e $20 \mu \mathrm{L}$ do soro controle positivo; e no poço central, $20 \mu \mathrm{L}$ do antígeno anti-CAEV. Após a aplicação as placas de Petri foram incubadas em atmosfera úmida em temperatura ambiente e, a leitura dos resultados foi feita após 72 horas, pela observação das placas em sala escura, com o auxílio de fonte luminosa. A reação foi classificada de acordo com a formação do complexo antígeno-anticorpo, conforme descrito a seguir: 
- Reação negativa: as linhas de precipitação formadas entre o antígeno e o soro controle positivo dirigem-se para a cavidade onde se encontram as amostras testadas;

- Reação positiva: as linhas de precipitação formadas entre o antígeno e o soro controle positivo fundem-se com a linha de precipitação formada pelas amostras testadas formando uma linha contínua.

Constituição dos grupos amostrais

Somente cabras que não apresentaram episódios recorrentes de mamite, alterações das características macroscópicas do leite, detectadas na prova do fundo escuro, ou na consistência da glândula mamária, detectada por palpação após a ordenha, relacionadas a processo inflamatório (BIRGEL, 2004) foram utilizadas no estudo. Nos experimentos 3 e 4 foram utilizadas somente cabras sororeagentes negativas ao antígeno do vírus da CAE e nos experimentos 3 e 5 foram utilizadas somente amostras de leite negativas no exame microbiológico.

\subsection{Proteinograma do leite de cabras durante a lactação plena: valores de referência, influência da fase de lactação e do número de lactações.}

Para a avaliação da influência da fase de lactação no proteinograma do leite de cabras foram utilizadas 237 amostras colhidas de 98 cabras que foram divididas em 6 grupos amostrais de acordo com os dias de lactação:

- Grupo 1: 40 amostras entre $0-15$ dias de lactação;

- Grupo 2: 40 amostras entre 15 - 30 dias de lactação;

- Grupo 3: 40 amostras entre 30 -60 dias de lactação;

- Grupo 4: 40 amostras entre 60 - 120 dias de lactação;

- Grupo 5: 40 amostras entre 120 - 210 dias de lactação;

- Grupo 6: 37 amostras acima de 210 dias de lactação 
Para a determinação dos valores de referencia das proteínas do leite de cabras durante a lactação plena, foram utilizadas as 160 amostras de leite dos grupos entre 15 e 210 dias de lactação provenientes de 71 cabras, descartando as cabras que estavam no início e no final da lactação impedindo as influências da fase de lactação.

Para a avaliação da influência do número de lactações no proteinograma do leite de cabras foram utilizadas 114 amostras colhidas de 64 cabras entre 30 e 210 dias de lactação que foram divididas em 4 grupos amostrais:

- Grupo 1:30 amostras de cabras com 1 lactação;

- Grupo 2: 30 amostras de cabras com 2 lactações;

- Grupo 3: 24 amostras de cabras com 3 lactações;

- Grupo 4: 30 amostras de cabras entre 4 e 5 lactações

\subsection{Avaliação da influência do isolamento bacteriano no proteinograma do leite de cabras.}

Para a avaliação da influência do isolamento bacteriano nas proteínas do leite de cabras durante a lactação plena foram utilizadas 88 amostras provenientes de 65 cabras entre 30 e 210 dias de lactação que foram divididas em dois grupos amostrais de acordo com o resultado do exame bacteriológico:

- Grupo experimental: constituído por 44 amostras de leite positivas no exame bacteriológico provenientes de 36 cabras da raça Saanen.

- Grupo Controle: constituído por 44 amostras de leite negativas no exame bacteriológico provenientes de 29 cabras da raça Saanen. 


\subsection{Avaliação da influência da infecção do Vírus da Artrite-encefalite caprina (CAEV) no proteinograma do leite de cabras.}

Para a avaliação da influência da infecção pelo Vírus CAE nas proteínas do leite de cabras da raça Saanen foram utilizadas 100 amostras de leite colhidas de 58 cabras da raça Saanen que estavam entre 30 e 210 dias de lactação que foram divididas em dois grupos amostrais de acordo com o resultado da imunodifusão em gel de Agar (IDGA) para diagnóstico de CAE:

- Grupo experimental: constituído por 50 amostras provenientes de 27 cabras sororeagentes positivas ao antígeno do vírus da CAE.

- Grupo Controle: constituído por 50 amostras provenientes de 31 cabras negativas ao antígeno do vírus da CAE.

\subsection{Colheita das amostras}

No momento da colheita das amostras dos estudos 1 e 2 as cabras eram individualmente retiradas das baias e contidas com de cabrestos. Antes de cada colheita foi realizada a higienização dos tetos com solução de hipoclorito de sódio (pré-dipping) e posterior secagem individual com papel toalha. Após os procedimentos de higienização, foi realizado o exame da caneca escuro seguido da colheita das amostras de cada teto.

As amostras de leite dos estudos 3, 4 e 5 foram colhidas antes da ordenha, após os procedimentos rotineiros de preparo, com limpeza dos tetos com solução de hipoclorito de sódio (pré-dipping), posterior secagem individual com papel toalha e exame da caneca de fundo escuro.

Foram colhidas três alíquotas de leite de cada um dos tetos para as diferentes análises: alíquotas para exame microbiológico - 3,0 $\mathrm{mL}$ em tubos plásticos estéreis, precedida por assepsia do orifício do teto, com gaze embebida em álcool 70\% e descarte dos primeiros jatos evitando resíduos de anti-sépticos, e mantidas refrigeradas; alíquotas para obtenção do soro lácteo - $50 \mathrm{~mL}$ em frascos de plástico 
mantidas refrigeradas; alíquotas para determinação de proteína total - $20 \mathrm{~mL}$ em frascos de plástico contendo conservante à base de bronopol (2-bromo-2-nitropropano-1,3-diol) e natamycin mantidas a temperatura ambiente.

\subsection{Análises}

Exame microbiológico: realizado através da semeadura das amostras em meio ágar-sangue de carneiro que foram incubadas a $37^{\circ} \mathrm{C}$, com as leituras realizadas após 24, 48 e 72 horas. Os exames bacterioscópicos foram realizados em lâminas coradas pelo Método de Gram. Sendo que as bactérias isoladas do gênero Staphylococcus foram identificadas por provas bioquímicas de acordo com as técnicas descritas por Lennette (1985), e classificados de acordo com o Bergey's Manual of Systematic Bacteriology (KRIEG; HOLT, 1984)

Proteína total, lactose, gordura e sólidos totais do leite: determinada utilizando analisador infravermelho de leite (BENTLEY $2000^{\circledR}$ ) realizada na Clínica do Leite do Departamento de Zootecnia da Escola Superior de Agricultura "Luiz de Queiroz" ESALQ - USP Piracicaba.

Eletrocondutividade e $\mathrm{pH}: \mathrm{pH}$ realizado em phmetro digital modelo M20 da Digmed e eletrocondutividade determinada através do aparelho Milku Mastitron.

As análises físico-químicas do leite foram realizadas como triagem, não sendo utilizadas as amostras que apresentaram alterações nessas análises, descartando as glândulas com mamite.

Obtenção do soro lácteo: o soro lácteo foi obtido através da coagulação do leite pela adição de $5 \%$ de solução de renina conforme recomendações de Sant'Ana e Birgel (2003)

Proteína total do soro lácteo: A proteína total do soro lácteo foi determinada pelo método de Biureto adaptado para o uso em soro lácteo através de curva padrão. Para a obtenção da curva padrão foram utilizadas 30 amostras de leite de 
vacas, selecionadas segundo a fase de lactação, com grande concentração de proteínas, ou seja, fase de secagem e de colostro. O soro lácteo obtido foi centrifugado a $16.000 \mathrm{~g}$ (13.000 rpm) por 20 minutos utilizando centrífuga de microtubos Biofuge Pico da Heraeus Instruments, eliminando a turbidez da amostra evitando interferências na leitura da absorbância. Inicialmente a proteína total do leite foi obtida pelo método de Kjeldhal, padrão ouro, e em seguida dependendo do teor de proteína as amostras foram diluídas em água MiliQ obtendo-se até 10 diluições. As amostras e suas diluições foram analisadas pelo método de Biureto, que consiste na reação colorimétrica do reativo de Biureto $(3 \mathrm{~mL})$ com a proteína da amostra (50 $\mu \mathrm{L}$ de soro lácteo), obtidas pela leitura da absorbância em espectrofotômetro com comprimento de onda igual a $555 \mathrm{~nm}$. A proteína das diluições foi calculada a partir do valor da amostra inicial obtido pelo método de Kjeldhal. A curva padrão e a equação da reta foram confeccionadas no programa Excell 2007 a partir das absorbâncias e da proteína obtida pelo método de Kjeldhal.

A comparação das metodologias demonstrou alta correlação $(r=0,989)$. A curva padrão obtida foi linear e apresentou boa aplicabilidade em amostras com absorbância variando entre 0,03 e 0,500, ou seja, para concentrações de proteína entre 0,80 e 12,00 g/dL, obtendo-se a seguinte equação da reta: Proteína do soro lácteo $=($ Absorbância - 0,005) / 0,050 (Gráficos 1 e 2).

Para assegurar que nenhum outro constituinte do leite pudesse interferir na reação do Biureto foram feitas as seguintes determinações:

Lactose - lactose P.A. da marca Interlab foi diluída em água MiliQ para obtenção de soluções nas seguintes concentrações 1\%, 5\%, 10\%. Amostras das soluções foram analisadas pela metodologia do Biureto verificando que a Lactose não interferiu na leitura da absorbância.

Outros constituintes do contidos no soro lácteo: Amostras de soro lácteo foram colocadas em água em ebulição a $100^{\circ} \mathrm{C}$, por 20 minutos para denaturar as proteínas, em seguida o sobrenadante foi avaliado pelo método do Biureto demonstrando que nenhum outro componente reagiu com o Biureto interferindo na leitura da absorbância. 


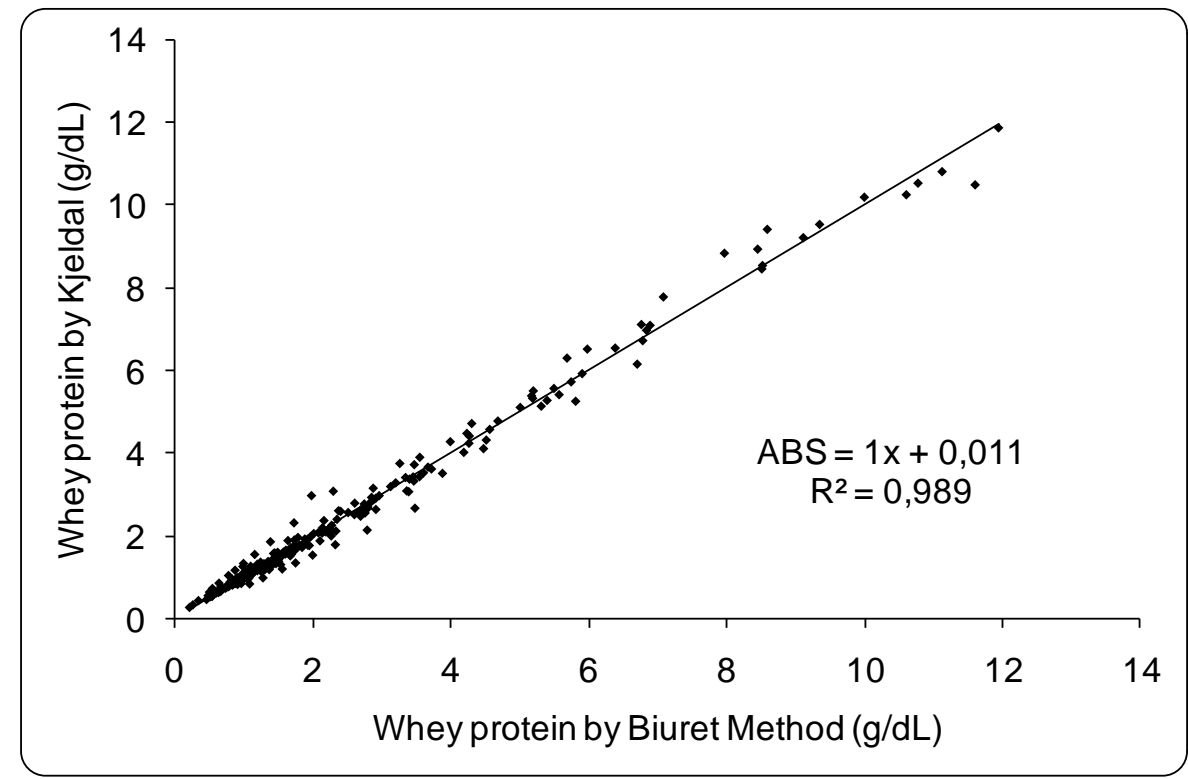

Gráfico 1- Comparação dos valores de proteína do soro lácteo determinados pelo método de Biureto e método de Kjeldahl - São Paulo - 2008

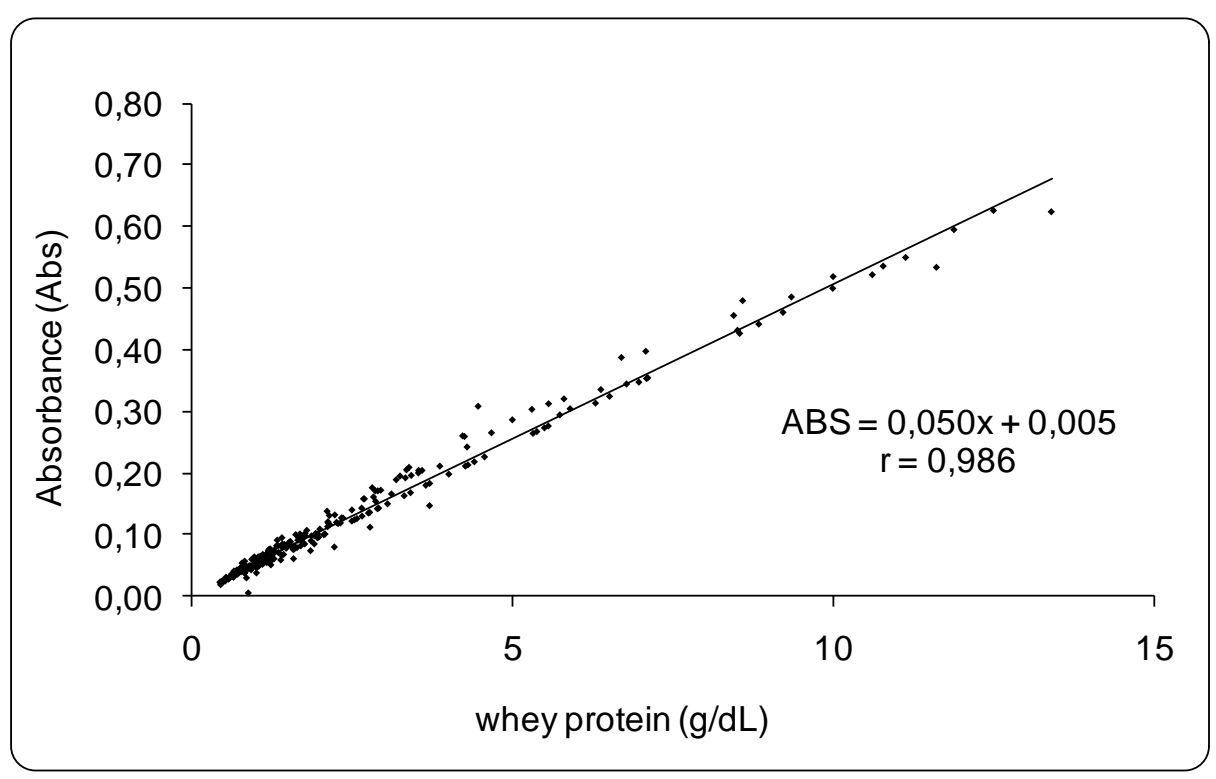

Gráfico 2 - Curva padrão para determinação de proteína total do soro lácteo pelo método de Biureto - São Paulo - 2008

Fracionamento das proteínas do soro de leite: determinado por eletroforese em gel de poliacrilamida a 12\% (SDS-PAGE) conforme técnica descrita por Laemmli (1970) e recomendações de Raimondo, Miyashiro e Birgel Junior (2009). A corrida de eletroforese foi realizada em cuba vertical no sistema descontínuo, com dois géis de diferentes concentrações, gel empilhador (4\%) e gel separador (12\%). As proteínas das amostras foram desnaturadas por aquecimento a $100^{\circ} \mathrm{C}$ na presença 
de 2-mercaptoetanol e do detergente dodecil sulfato de sódio (SDS). Os géis foram corados com Coomassie Blue, durante 10 minutos, e descorados a seguir com solução descorante (metanol e ácido acético glacial) overnight. A análise dos géis foi realizada em densitômetro, modelo Epson Expression 1680. A determinação e a quantificação das proteínas através do peso molecular foi realizada no Life Science Software - Vision Works LS (Image Acquisitions and Analysis Software - UVP), através de padrão de peso molecular comercial da marca Bio-Rad ${ }^{\circledR}$, modelo Precision Plus Protein Standards Kaleidoscope, com 10 bandas de variação entre $250 \mathrm{KDa}$ e $10 \mathrm{KDa}$ e proteínas comerciais purificadas da Sigma ${ }^{\circledR}$ (lactoferrina, albumina sérica, imunoglobulina $G$ bovina, imunoglobulina A humana, $\beta$ lactoglobulina e $\alpha$-lactoalbumina), corridas juntamente com as amostras.

\subsection{Análise estatística:}

ESTUDO 1 e 2 - para a análise descritiva dos dados foram calculados a média, desvio padrão e o intervalo de confiança (95\%). Para comparação das proteínas foi utilizado analise de variância (ANOVA) para os casos em que o $p$-valor foi significativo foi feita a comparação 2 a 2 (teste T- Student) entre os momentos de colheita com um nível de significância de $5 \%$ (p-valor $\leq 0,05$ ).

ESTUDO 3 - para a análise descritiva dos dados foi calculado média e desvio padrão e intervalo de confiança (95\%). Para comparação das proteínas do soro lácteo durante as fases de lactação e em relação ao número de lactações foi utilizado analise de variância (ANOVA) e comparação múltipla com teste de Bonferroni. Para a determinação dos valores de referência para o proteinograma do leite de cabras Saanen foi calculado média e desvio padrão e intervalo de confiança (95\%). Para verificar se houve correlação entre as proteínas do soro foi utilizado o coeficiente de correlação de Spearman.

ESTUDOS 4 e 5 - para a análise descritiva dos dados foi calculado média e desvio padrão e intervalo de confiança (95\%). Para comparação dos dados do grupo experimental e do grupo controle foi utilizado analise de variância (ANOVA). 
Resultados e discussāo

$$
=={ }_{z=}={ }_{z=}==_{i=}=\mathrm{M}
$$




\section{RESULTADOS E DISCUSSÃO}

\subsection{Avaliação da influência do processo de secagem da glândula mamária no proteinograma da secreção láctea de cabras}

Durante o processo de secagem da glândula mamária de caprinos (Tabela 3 e Gráfico 3) demonstrou-se o aumento progressivo dos teores lácteos de proteína total da secreção. Na última ordenha o teor médio de proteína total foi igual a $3.210,0 \pm 1.020,0 \mathrm{mg} / \mathrm{dL}$ aumentando até $010^{\circ}$ dia de secagem quando a concentração de proteína estabiliza até o final do mês, o valor máximo foi observado aos 15 dias de secagem $(5.450,0 \pm 1.960,0 \mathrm{mg} / \mathrm{dL})$. O aumento da concentração da proteína total durante a involução da glândula mamária está de acordo com estudos anteriores que também observaram o mesmo comportamento protéico em caprinos e bovinos (ZIV; GORDIN, 1973; SMITH; TODHUNTER, 1982; HURLEY; REJMAN, 1986; HURLEY, 1989; ASLAM et al., 1994; SHAMAY et al., 2003; BIRGEL, 2006; WENG et al., 2006; BRANDESPIM, 2007).

O aumento na proteína total foi ocasionado pelo aumento progressivo das proteínas do soro lácteo (Tabela 3 e Gráfico 3). Verificou-se que os teores médios de proteína do soro foram iguais a 900,0 $\pm 566,6 \mathrm{mg} / \mathrm{dL}$ na última ordenha, aumentando progressivamente, atingindo o valor máximo igual a 3.843,0 $\pm 1.173,7$ $\mathrm{mg} / \mathrm{dL}$ aos 30 dias de secagem.
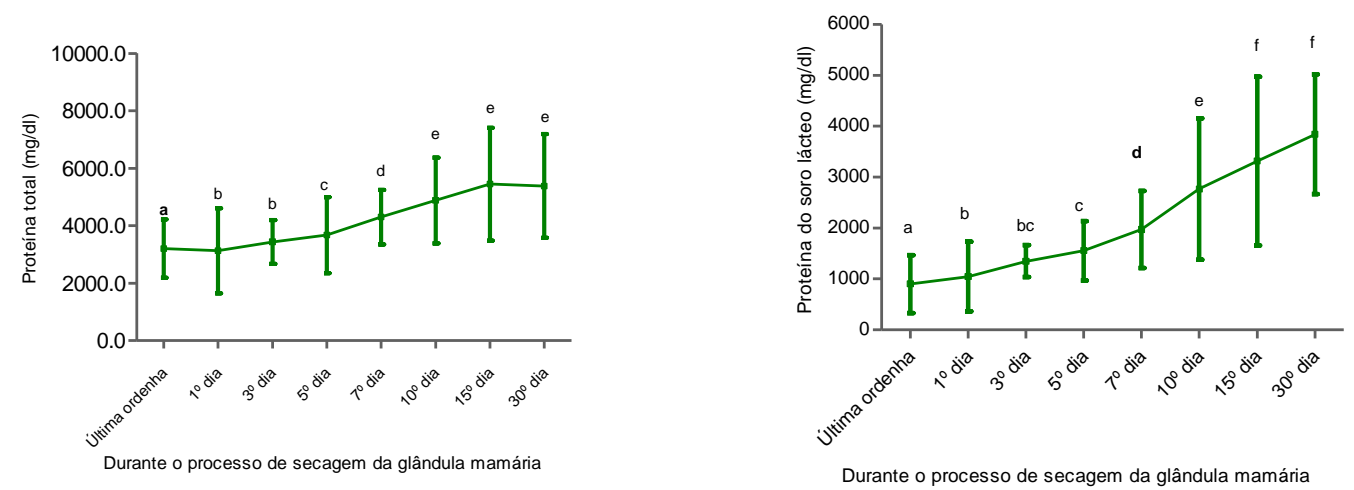

Legenda: Letras diferentes significam diferença estatística significante $(p \leq 0,05)$ - Teste t de Student

Gráfico 3 - Avaliação da influência do processo de secagem nos teores de proteína total e proteína do soro lácteo de cabras Saanen - São Paulo - 2007 a 2010. 
Durante a avaliação do comportamento das frações protéicas encontradas durante o processo de secagem da glândula mamária pode-se observar, a partir do $5^{\circ}$ dia de secagem, o aumento significativo nos valores absolutos das diversas frações protéicas: lactoferrina - 84,0 $\pm 4,0 \mathrm{kDa}$; albumina sérica - 66,0 $\pm 2,0 \mathrm{kDa}$; imunoglobulinas cadeia pesada - 52,0 $\pm 2,0 \mathrm{KDa}$; imunoglobulinas de cadeia leve $26,0 \pm 1,5 \mathrm{kDa} ; \beta-\mathrm{Lg}-16,0 \pm 1,0 \mathrm{kDa}$ e $\alpha-\mathrm{La}-12,0 \pm 0,65 \mathrm{kDa}$ e o surgimento de outras frações que não foram observadas anteriormente. Contudo, observou-se modificação na distribuição percentual das frações protéicas do soro lácteo de cabras associada ao aparecimento das novas frações (Gráfico 4 e Gráfico 5).
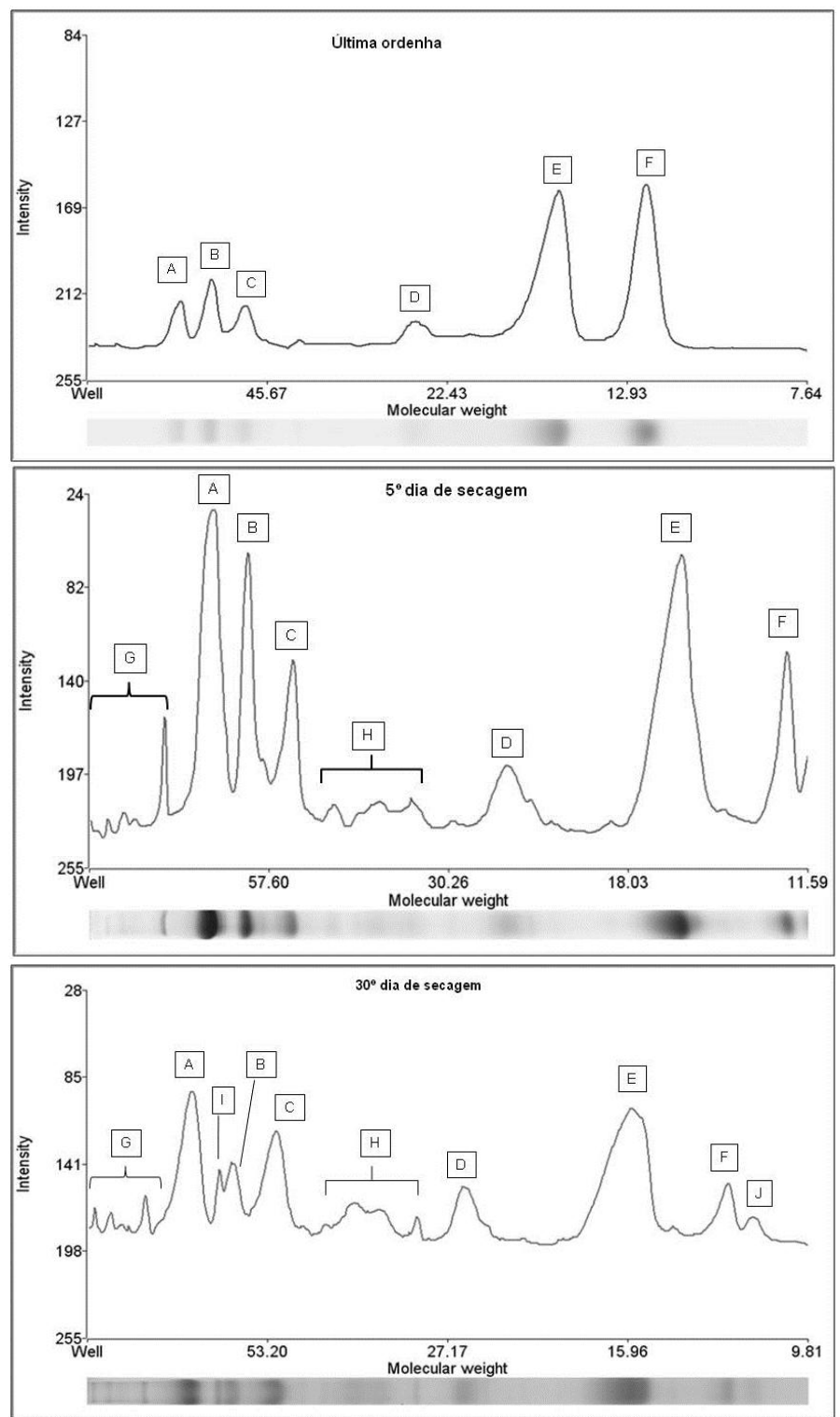

Legenda: A - lactoferrina; B - albumina sérica; C - Ig cadeia pesada; D - Ig cadeia leve; E - $\beta$-Lg; F - $\alpha$-La;

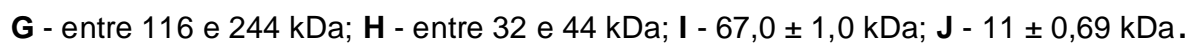

Gráfico 4 - Eletroforetograma das proteínas do soro lácteo de cabras da raça Saanen durante o processo de secagem da glândula mamária, obtido através de eletroforese em gel de poliacrilamida (12\%) (SDS-PAGE) - São Paulo - 2007 a 2010 
A concentração de $\beta$-Lg (Tabela 3 e Gráfico 5 e 6) aumenta progressivamente de $272,5 \pm 149,7 \mathrm{mg} / \mathrm{dL}$ na última ordenha para $792,0 \pm 375,5 \mathrm{~m} / \mathrm{dL}$ no $30^{\circ}$ dia de secagem, enquanto que a concentração de $\alpha$-La igual a $182,5 \pm 105,4 \mathrm{mg} / \mathrm{dL}$ na última ordenha aumenta ao longo do período de secagem, contudo com pouca variação. Apesar do aumento nas concentrações de $\beta$ - $L g$ e $\alpha$-La a percentagem dessas proteínas em relação à proteína do soro lácteo, durante o período estudado, diminuiu. Na última ordenha a $\beta-\operatorname{Lg}(31 \%)$ e $\alpha-\operatorname{La~}(21 \%)$ correspondiam a mais da metade da proteína do soro lácteo (52\%), no $5^{0}$ dia de secagem apesar do surgimento de novas frações protéicas e do aumento nas concentrações das proteínas a percentagem de $\beta-\operatorname{Lg}(42 \%)$ foi máxima enquanto que a de $\alpha$-La $(20 \%)$ não varia, a partir do $10^{\circ}$ dia ocorre diminuição nessas percentagens sendo que no $30^{\circ}$ dia de secagem a percentagem de $\beta$ - $\mathrm{Lg}(20 \%)$ e $\alpha$-La $(7 \%)$ representam $27 \%$ da proteína do soro lácteo. Pesquisas realizadas por Hurley e Rejman (1986) e Aslam (1994) em vacas evidenciaram fato semelhante.

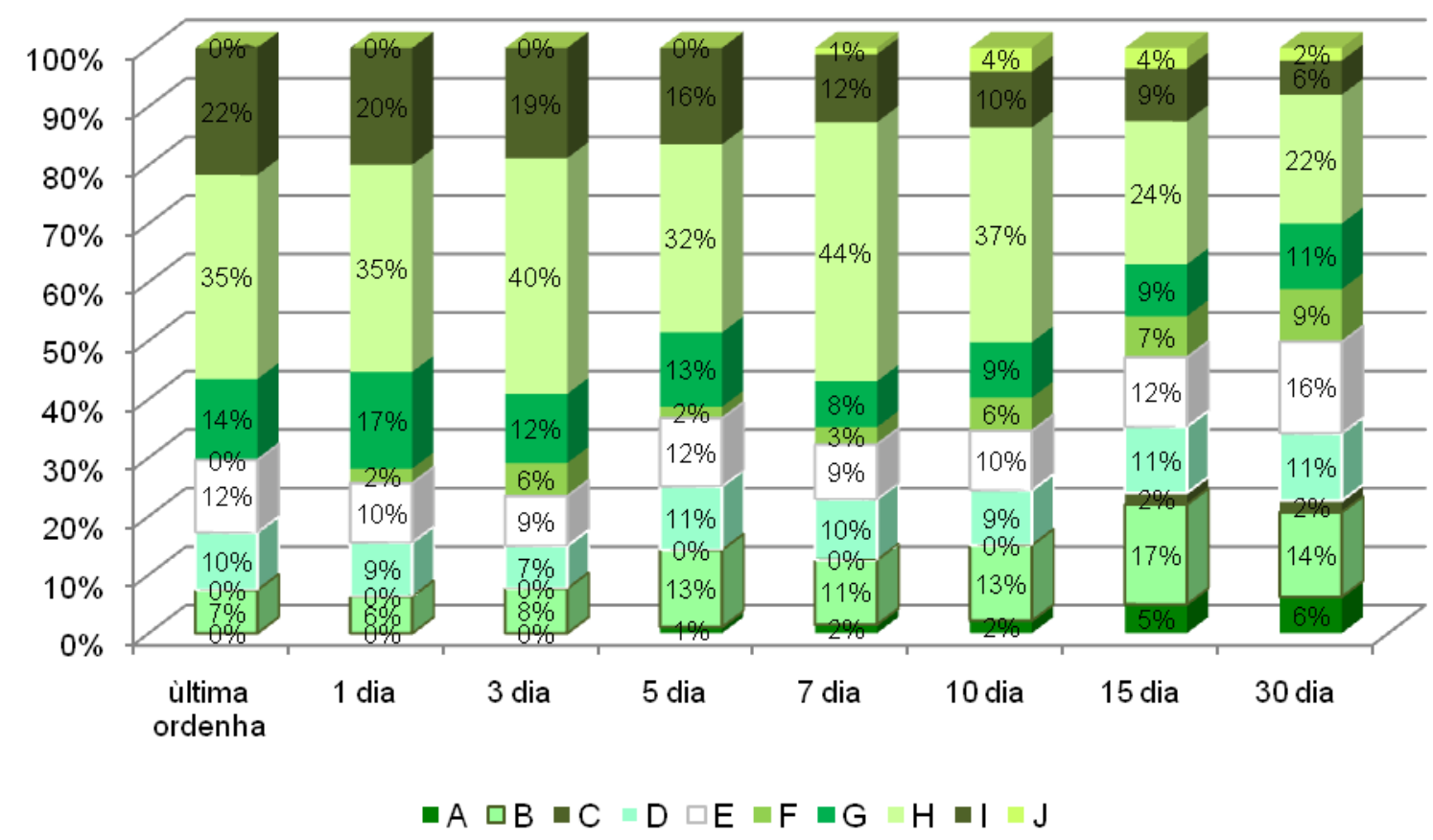

Legenda: A - 100 a 290 kDa; B - Lactoferrina; C - 67,0 $\pm 1,0 \mathrm{kDa}$; D - Albumina; E - Ig pesada; F - 30 a 44 kDa;

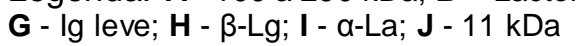

Gráfico 5 - Concentração (\%) das proteínas fracionadas do soro lácteo de cabras Saanen em relação à proteína do soro durante o processo de secagem da glândula mamária obtida através da técnica de eletroforese em gel de poliacrilamida (12\%) (SDS-PAGE) - São Paulo 2007 a 2010. 
A lactoferrina (Tabela 3 e Gráficos 5 e 6) aumenta sua percentagem de 7\% na última ordenha para $12 \%$ no $30^{\circ}$ dia, sendo que o teor médio de lactoferrina na última ordenha igual a $81,7 \pm 50,4 \mathrm{mg} / \mathrm{dL}$ aumenta progressivamente após o $3^{\circ} \mathrm{dia}$ de secagem $(120,0 \pm 35,3 \mathrm{mg} / \mathrm{dL})$ chegando ao teor máximo no $30^{\circ}$ dia de secagem com média igual a 480,0 $\pm 159,4 \mathrm{mg} / \mathrm{dL}$. O aumento relativo e absoluto dos teores lácteos de lactoferrina durante a secagem da glândula mamária está de acordo com a literatura compulsada (REJMAN; HURLEY; BAHR, 1989; HURLEY; REJMAN, 1993; HAGIWARA et al., 2003; CHENG et al., 2008; HISS; MEYER; SAUERWEIN, 2008), pois essa glicoproteína tem papel importante na defesa da glândula mamária (ELLISON; GIEHL; LAFORCE, 1988; SORDILLO; SHAFER-WEAVER; DEROSA, 1997; HURLEY; JUNIOR, 2003; CHANETON et al., 2008).

Os teores de albumina sérica (Tabela 3 e Gráficos 5 e 6) observados durante o processo de secagem da glândula mamária aumentam progressivamente a partir do $5^{\circ}$ dia. Os valores médios obtidos na última ordenha iguais a 98,2 $\pm 61,6 \mathrm{mg} / \mathrm{dL}$ chegam ao valor máximo no $30^{\circ}$ dia de secagem com média igual a $287,5 \pm 139,3$ $\mathrm{mg} / \mathrm{dL}$.

O uso de 2-mercaptoetanol durante o processamento das amostras submetidas à eletroforese SDS-PAGE determina a denaturação das proteínas com rompimento das pontes dissulfeto das imunoglobulinas e, como conseqüência, a divisão em duas cadeias, pesada e leve (Gráfico 4). Com o rompimento dessas pontes, não foi possível identificar separadamente cada classe de imunoglobulina envolvida, pois as cadeias leves e pesadas, independentes da classe possuem 0 mesmo peso molecular e são fracionadas na mesma posição na técnica de eletroforese SDS-PAGE. Ambas as cadeias de imunoglobulinas são influenciadas pelo processo de secagem da glândula mamária, pois aumentam progressivamente com o evoluir do processo de secagem.

$\mathrm{Na}$ última ordenha (Tabela 3 e Gráficos 5 e 6 ) os teores médios de imunoglobulina cadeia pesada são iguais a $116,7 \pm 88,0 \mathrm{mg} / \mathrm{dL}$ e imunoglobulina leve iguais a $148,2 \pm 126,3 \mathrm{mg} / \mathrm{dL}$ alcançando os teores máximos no $30^{\circ}$ dia de secagem quando a média de imunoglobulina cadeia pesada é igual a 501,5 $\pm 233,3$ $\mathrm{mg} / \mathrm{dL}$ e de cadeia leve igual a 460,7 $\pm 192,2 \mathrm{mg} / \mathrm{dL}$ (Tabela 3 e Gráficos 5 e 6). Hurley e Rejman (1986) avaliando o perfil eletroforético (SDS-PAGE) da secreção láctea de vacas durante a secagem descreveram aumento da concentração de proteínas com peso molecular de $37 \mathrm{KDa}$ e $28 \mathrm{KDa}$ partir do meio do período seco, 
entretanto ao invés de creditarem esse achado ao rompimento das pontes de dissulfeto das imunoglobulinas em decorrência da metodologia utilizada, associaram a presença dessas frações como produtos da repartição parcial de $\lg G$ de cadeia pesada durante o transporte através das células epiteliais secretoras.

Segundo a literatura compulsada, durante o período seco o declínio da atividade glandular acarreta alteração na composição da secreção mamária, devido à diminuição da síntese de caseína, $\beta$-Lg e $\alpha$-La (HURLEY, 1989) e aumento da concentração das proteínas de origem sanguínea no soro lácteo (albumina, lactoferrina e imunoglobulinas) associado as alterações nas junções celulares e aumento na permeabilidade dos vasos que ocorrem durante a involução da glândula mamária (LINZELL; PEAKER, 1971; HURLEY, 1989; BOUTINAUD et al., 2003).

Apesar das anteriores afirmações, os resultados obtidos na presente pesquisa discordam parcialmente com o que foi relatado, pois se por um lado observou-se o aumento na concentração de imunoglobulina, albumina sérica e lactoferrina por outro lado observou-se que os valores absolutos de $\beta$ - $L g$ e $\alpha$-La aumentaram durante os 30 primeiros dias do período seco. A análise desses resultados indica haver além de um processo de reabsorção de água que determinaria a concentração dos teores lácteos de $\beta$-Lg e $\alpha$-La, outro mecanismo que regularia o processo de síntese de $\beta$-Lg e/ou $\alpha$-La.

Além das proteínas normalmente observadas no soro lácteo de cabras foram observadas outras frações apresentadas através do peso molecular que não puderam ser nomeadas (Tabela 4 e Gráficos 5 e 7). A partir do 3o dia de secagem houve o aparecimento de frações protéicas localizadas entre as cadeias leve e pesada de imunoglobulinas com pesos moleculares que variaram entre 30 e $44 \mathrm{KDa}$, com a observação de até quatro frações dependendo da amostra colhida (pesos moleculares igual a 43,0 $\pm 1,0 \mathrm{KDa} ; 39,0 \pm 1,5 \mathrm{KDa} ; 36,0 \pm 2,0 \mathrm{KDa}$ e $31,0 \pm 1,0$ $\mathrm{KDa}$ ), como a presença de todas essas frações não foi constante em todas as amostras optou-se pela soma das frações e apresentação dos resultados como frações protéicas com peso molecular entre 30 e $44 \mathrm{KDa}$, os teores médios encontrados no $3^{\circ}$ dia foi igual a $112,6 \pm 45,0 \mathrm{mg} / \mathrm{dL}$, aumentando significativamente até $030^{\circ}$ dia de secagem quando a média encontrada foi igual a $513,5 \pm 269,5$ $\mathrm{mg} / \mathrm{dL}$.

A partir do $5^{\circ}$ dia de secagem foram observadas até 4 novas frações $(277,0 \pm$ 20,0 KDa; 204,0 \pm 50,0 KDa; 152,0 $\pm 20,0 \mathrm{KDa}$ e 124,0 $\pm 20,0 \mathrm{KDa}$ ) localizadas antes 
da fração da lactoferrina. Dependendo da amostra analisada, estavam presentes uma ou mais frações e pelo seu inconstante comportamento optou-se pela apresentação do resultado da soma dessas frações como proteínas com peso molecular entre 100 e $297 \mathrm{KDa}$, os valores médios no $5^{\circ}$ dia de secagem foi igual a $10,7 \pm 16,3 \mathrm{mg} / \mathrm{dL}$ aumentando progressivamente até o $30^{\circ}$ dia de secagem quando o valor médio obtido foi igual a 347,0 $\pm 154,8 \mathrm{mg} / \mathrm{dL}$ (Tabela 4 e Gráfico 7). Nas amostras colhidas a partir do $7^{\circ}$ dia de secagem foram observadas frações protéicas localizadas após a fração da $\alpha$-La com peso molecular médio de 11,0 $\pm 0,69 \mathrm{KDa}$, a concentração média foi igual a 46,0 $\pm 38,2 \mathrm{mg} / \mathrm{dL}$ no $7^{\circ}$ dia variando até $030^{\circ}$ dia quando o valor médio foi igual a 107,0 $\pm 91,0 \mathrm{mg} / \mathrm{dL}$ (Tabela 4 e Gráfico 7). Finalmente entre $015^{\circ}$ dia e $30^{\circ}$ dia de secagem, foi observado a presença de uma fração protéica entre a fração da lactoferrina e da albumina, com peso molecular médio de 67,0 $\pm 1,0 \mathrm{KDa}$. Essa fração protéica apresentou média igual a 72,0 \pm 64,0 $\mathrm{mg} / \mathrm{dL}$ no $15^{\circ}$ dia de secagem e $84,7 \pm 76,0 \mathrm{mg} / \mathrm{dL}$ no $30^{\circ}$ dia de secagem (Tabela 4 e Gráfico 7). As novas frações que aparecem durante o período seco representam $28 \%$ da proteína do soro lácteo no $30^{\circ}$ dia de secagem.

Após a cessação das ordenhas ocorre alteração da integridade das junções celulares e ativação do sistema ativador de plasminogênio (plasminogênio plasmina) (KORYCHA-DAHL et al., 1983; POLITIS et al., 1989; POLITIS; BARBANO; GOREWIT, 1992; ASLAM; HURLEY, 1997; FANTUZ et al., 2001; SHAMAY et al., 2003) dando início a proteólise em especial a hidrólise da caseína gerando fragmentos peptídeos com massas moleculares que variaram entre 2,5 e 13,5 KDa e com mais de 14 kDa (ASLAM; HURLEY, 1997). Apesar da caseína não ser estudada na presente pesquisa, o aparecimento de pequenas frações protéicas de diferentes pesos moleculares pode ser indicativo da hidrólise de caseína indicando que na glândula mamária de cabras ocorre a ativação do sistema ativador de plasminogênio (plasminogênio - plasmina) a partir do 5을 dia de secagem, período esse em que as frações protéicas aumentam mais abruptamente. 

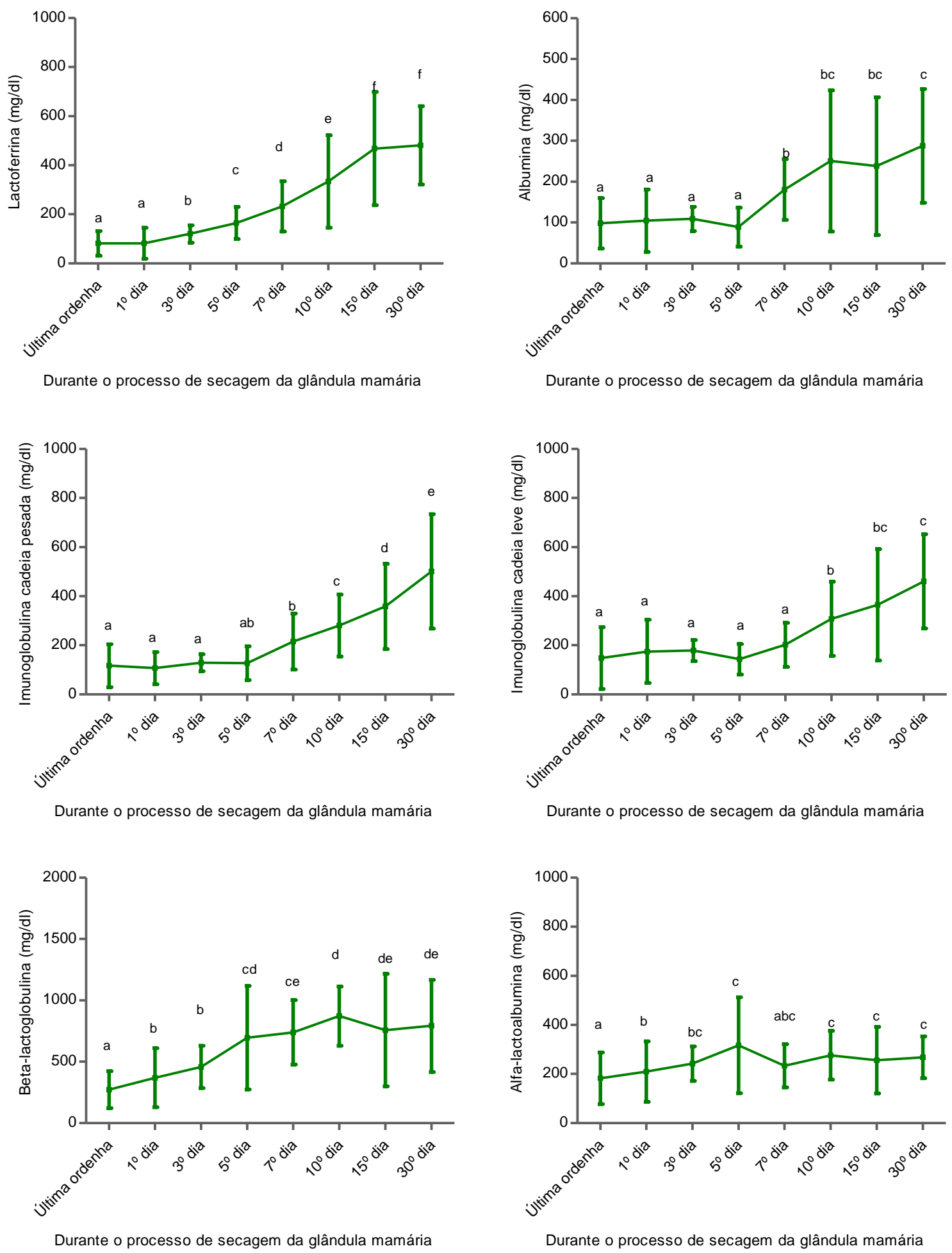

Legenda: Letras diferentes significam diferença estatística significante $(p \leq 0,05)$ - Teste t de Student

Gráfico 6 - Avaliação da influência do processo de secagem da glândula mamária nas frações protéicas do soro lácteo de cabras Saanen - São Paulo - 2007 a 2010 

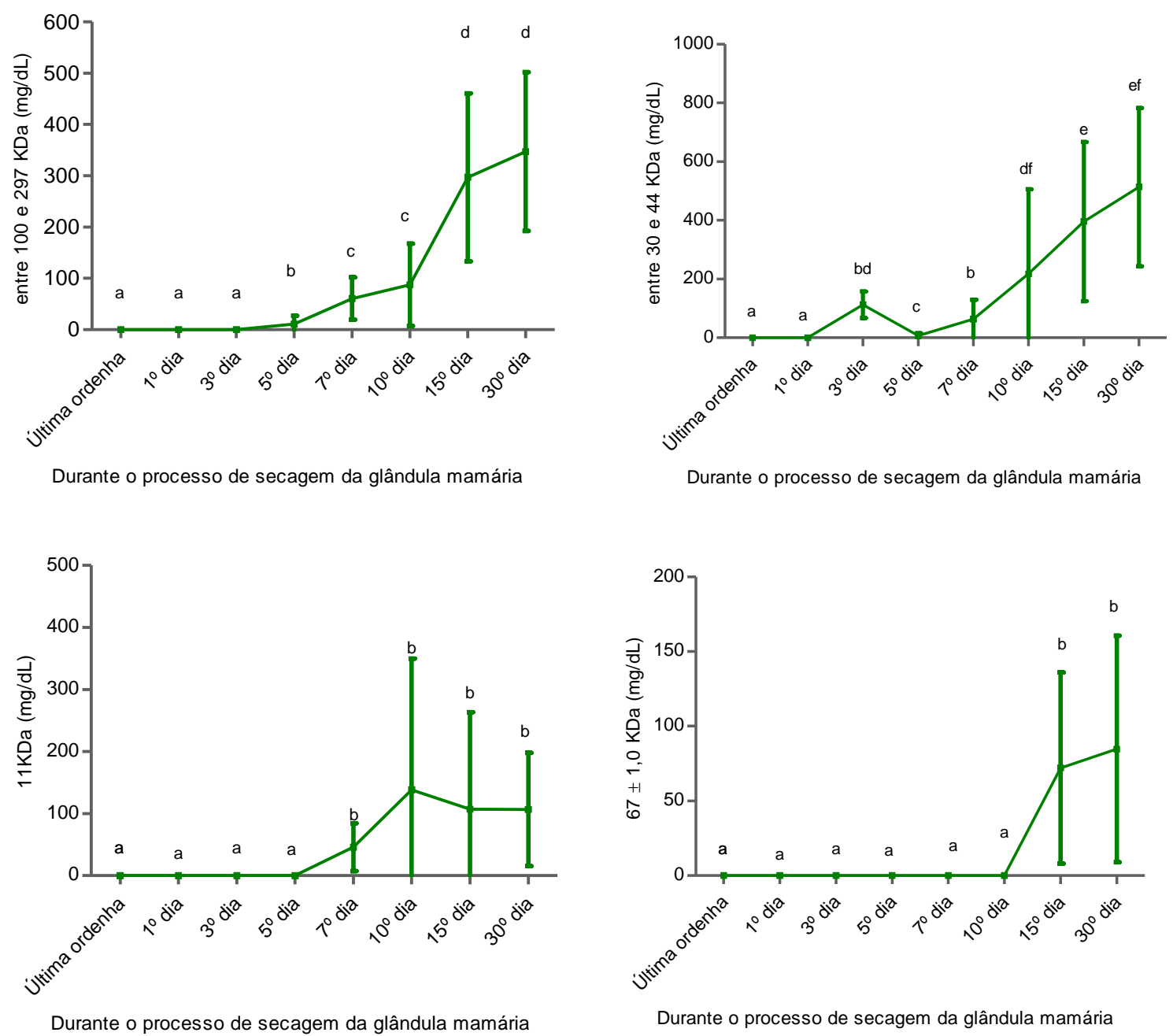

Legenda: Letras diferentes significam diferença estatística significante $(p \leq 0,05)$ - Teste t de Student

Gráfico 7 - Avaliação da influência do processo de secagem da glândula mamária nas frações protéicas do soro lácteo de cabras Saanen - São Paulo - 2007 a 2010. 
Tabela 3 - Média, desvio padrão (DP), intervalo de confiança (IC 95\%) da proteína total da secreção láctea, da proteína do soro lácteo e das frações protéicas (lactoferrina; albumina; imunoglobulinas de cadeia pesada; imunoglobulinas de cadeia leve; $\beta$-lactoglobulina e $\alpha$-lactoalbumina) durante o processo de secagem da glândula mamária de cabras Saanen - São Paulo - 2007 a 2010.

\begin{tabular}{|c|c|c|c|c|c|c|c|c|}
\hline \multicolumn{9}{|c|}{ PROTEINOGRAMA DA SECREÇÃO LÁCTEA DE CABRAS DURANTE O PERÍODO SECO } \\
\hline $\begin{array}{l}\text { Momentos de } \\
\text { colheita }\end{array}$ & $\begin{array}{l}\text { Proteína total } \\
\text { Média } \pm \text { DP } \\
\text { [IC 95\%] * }\end{array}$ & $\begin{array}{l}\text { Proteína do soro } \\
\text { Média } \pm \text { DP } \\
{[\text { IC } 95 \%]^{*}}\end{array}$ & $\begin{array}{l}\text { Lactoferrina } \\
\text { Média } \pm \text { DP } \\
{\left[\text { IC 95\% }{ }^{*}\right.}\end{array}$ & $\begin{array}{l}\text { Albumina } \\
\text { Média } \pm \text { DP } \\
\text { [IC 95\%] * }\end{array}$ & $\begin{array}{l}\text { Ig Pesada } \\
\text { Média } \pm \text { DP } \\
{[\text { IC 95\%] * }}\end{array}$ & $\begin{array}{c}\text { lg leve } \\
\text { Média } \pm \text { DP } \\
{[\text { IC 95\%] * }}\end{array}$ & $\begin{array}{c}\beta-\text { Lg } \\
\text { Média } \pm \text { DP } \\
{[\text { IC 95\%] * }}\end{array}$ & $\begin{array}{c}\text { a-La } \\
\text { Média } \pm \text { DP } \\
{[\text { IC 95\%] * }}\end{array}$ \\
\hline Última Ordenha & $\begin{array}{c}3.210,0 \pm 1.020,0 \\
{[2.540,0-4.020,0]}\end{array}$ & $\begin{array}{c}900,0 \pm 566,6 \\
{[592,0-1.208,0]}\end{array}$ & $\begin{array}{c}81,7 \pm 50,4 \\
{[54,0-109,0]}\end{array}$ & $\begin{array}{c}98,2 \pm 61,6 \\
{[64,0-131,0]}\end{array}$ & $\begin{array}{c}116,7 \pm 88,0 \\
{[67,0-164,0]}\end{array}$ & $\begin{array}{l}148,2 \pm 126,3 \\
{[75,5-217,0]}\end{array}$ & $\begin{array}{c}272,5 \pm 149,7 \\
{[191,0-354,0]}\end{array}$ & $\begin{array}{c}182,5 \pm 105,4 \\
{[125,0-2450,0]}\end{array}$ \\
\hline $1^{\circ} \mathrm{Dia}$ & $\begin{array}{c}3.390,0 \pm 1.190,0 \\
{[2.640,0-4.280,0]}\end{array}$ & $\begin{array}{c}1.047,7 \pm 686,0 \\
{[674,0-1.420,0]}\end{array}$ & $\begin{array}{c}82,3 \pm 63,0 \\
{[48,0-116,0]}\end{array}$ & $\begin{array}{c}104,8 \pm 76,4 \\
{[63,0-146,0]}\end{array}$ & $\begin{array}{c}107,0 \pm 66,0 \\
{[71,0 \pm 143,0]}\end{array}$ & $\begin{array}{c}174,7 \pm 128,7 \\
{[104,0-244,0]}\end{array}$ & $\begin{array}{c}369,4 \pm 240,0 \\
{[234,0-450,0]}\end{array}$ & $\begin{array}{c}209,3 \pm 123,2 \\
{[142,0-276,0]}\end{array}$ \\
\hline 3o Dia & $\begin{array}{c}3.430,0 \pm 760,0 \\
{[2.950,0-4.050,0]}\end{array}$ & $\begin{array}{c}1.349,2 \pm 313,7 \\
{[1.178,0-1.519,0]}\end{array}$ & $\begin{array}{c}120,3 \pm 35,3 \\
{[101,0-139,0]}\end{array}$ & $\begin{array}{c}109,2 \pm 30,0 \\
{[93,0-125,0]}\end{array}$ & $\begin{array}{c}128,8 \pm 34,8 \\
{[110,0-147,0]}\end{array}$ & $\begin{array}{c}178,4 \pm 43,0 \\
{[155,0-201,0]}\end{array}$ & $\begin{array}{c}458,2 \pm 175,0 \\
{[364,0-551,0]}\end{array}$ & $\begin{array}{c}241,6 \pm 70,6 \\
{[203,0-280,0]}\end{array}$ \\
\hline 5o Dia & $\begin{array}{c}3.980,0 \pm 760,0 \\
{[3.510,0-4.550,0]}\end{array}$ & $\begin{array}{c}1.555,3 \pm 582,8 \\
{[1.238,0-1.872,0]}\end{array}$ & $\begin{array}{c}164,5 \pm 65,4 \\
{[129,0-200,0]}\end{array}$ & $\begin{array}{c}89,0 \pm 47,4 \\
{[63,0-114,0]}\end{array}$ & $\begin{array}{c}127,0 \pm 69,0 \\
{[89,0-164,0]}\end{array}$ & $\begin{array}{c}143,4 \pm 62,2 \\
{[109,0-177,0]}\end{array}$ & $\begin{array}{c}696,2 \pm 422,3 \\
{[466,0-925,0]}\end{array}$ & $\begin{array}{c}317,0 \pm 196,0 \\
{[210,0-423,0]}\end{array}$ \\
\hline 7음a & $\begin{array}{c}4.300,0 \pm 940,0 \\
{[3.680,0-5.020,0]}\end{array}$ & $\begin{array}{c}1.973,8 \pm 754,3 \\
{[1.563,0-2.384,0]}\end{array}$ & $\begin{array}{c}232,4 \pm 103,0 \\
{[176,0-288,0]}\end{array}$ & $\begin{array}{c}180,7 \pm 74,7 \\
{[140,0-221,0]}\end{array}$ & $\begin{array}{c}215,2 \pm 114,3 \\
{[153,0-277,0]}\end{array}$ & $\begin{array}{c}201,7 \pm 89,7 \\
{[153,0-250,0]}\end{array}$ & $\begin{array}{c}739,8 \pm 263,0 \\
{[596,0-882,0]}\end{array}$ & $\begin{array}{c}233,4 \pm 88,0 \\
{[185,0-281,0]}\end{array}$ \\
\hline 10임 & $\begin{array}{c}4.880,0 \pm 1.490,0 \\
{[3.900,0-6.020,0]}\end{array}$ & $\begin{array}{c}2.766,0 \pm 1.388,3 \\
{[2.011,0-3.521,0]}\end{array}$ & $\begin{array}{c}333,6 \pm 188,3 \\
{[231,0-436,0]}\end{array}$ & $\begin{array}{c}251,0 \pm 172,6 \\
{[157,0-344,0]}\end{array}$ & $\begin{array}{c}280,4 \pm 126,6 \\
{[211,0-349,0]}\end{array}$ & $\begin{array}{c}308,3 \pm 151,2 \\
{[226,0-390,0]}\end{array}$ & $\begin{array}{c}872,3 \pm 241,0 \\
{[741,0-1003,0]}\end{array}$ & $\begin{array}{c}276,6 \pm 99,0 \\
{[222,0-330,0]}\end{array}$ \\
\hline 15음a & $\begin{array}{c}5.450,0 \pm 1.960,0 \\
{[4.250,0-6.980,0]}\end{array}$ & $\begin{array}{c}3.315,5 \pm 1.659,4 \\
{[2.413,0-4.217,0]}\end{array}$ & $\begin{array}{c}468,0 \pm 230,6 \\
{[342,0-593,0]}\end{array}$ & $\begin{array}{c}238,0 \pm 168,6 \\
{[146,0-329,0]}\end{array}$ & $\begin{array}{c}358,3 \pm 173,5 \\
{[264,0-452,0]}\end{array}$ & $\begin{array}{c}364,7 \pm 227,9 \\
{[241,0-488,0]}\end{array}$ & $\begin{array}{c}757,3 \pm 457,7 \\
{[508,0-1006,0]}\end{array}$ & $\begin{array}{c}256,2 \pm 135,8 \\
{[182,0-330,0]}\end{array}$ \\
\hline 30 ㅁ Dia & $\begin{array}{c}5.380,0 \pm 1.800,0 \\
{[4.050,0-6.700,0]}\end{array}$ & $\begin{array}{c}3.843,0 \pm 1.173,7 \\
{[3.205,0-4.481,0]}\end{array}$ & $\begin{array}{c}481,0 \pm 159,4 \\
{[394,0-567,0]}\end{array}$ & $\begin{array}{c}287,5 \pm 139,3 \\
{[211,0-363,0]}\end{array}$ & $\begin{array}{c}501,5 \pm 233,3 \\
{[374,0,-628,0]}\end{array}$ & $\begin{array}{c}460,7 \pm 192,2 \\
{[356,0-565,0]}\end{array}$ & $\begin{array}{c}792,0 \pm 375,5 \\
{[588,0-996,0]}\end{array}$ & $\begin{array}{c}268,0 \pm 84,8 \\
{[222,0-314,0]}\end{array}$ \\
\hline
\end{tabular}


Tabela 4 - Média, desvio padrão (DP), intervalo de confiança (IC 95\%) das frações protéicas (proteínas com peso molecular entre 100 - $290 \mathrm{KDa}$; proteínas com peso molecular entre $30-44 \mathrm{KDa}$ e proteínas com peso molecular entre $10-12 \mathrm{KDa}$ ) durante o processo de secagem da glândula mamária de cabras Saanen. São Paulo 2010.

\begin{tabular}{|c|c|c|c|c|}
\hline $\begin{array}{l}\text { Momentos de } \\
\text { colheita }\end{array}$ & $\begin{array}{c}\text { Entre } 100-297 \mathrm{KDa} \\
\text { Média } \pm \text { DP } \\
{[\text { IC } 95 \%]^{*}}\end{array}$ & $\begin{array}{c}\text { Entre } 30 \text { - } 44 \mathrm{KDa} \\
\text { Média } \pm \mathrm{DP} \\
\text { [IC 95\%] * }\end{array}$ & $\begin{array}{c}67,0 \pm 1,0 \mathrm{KDa} \\
\text { Média } \pm \mathrm{DP} \\
{[\mathrm{IC} 95 \%]^{*}}\end{array}$ & $\begin{array}{c}11,0 \pm 0,69 \mathrm{KDa} \\
\text { Média } \pm \mathrm{DP} \\
{[\mathrm{IC} 95 \%]^{*}}\end{array}$ \\
\hline Última Ordenha & 0,0 & 0,0 & 0,0 & 0,0 \\
\hline $1^{\circ} \mathrm{Dia}$ & 0,0 & 0,0 & 0,0 & 0,0 \\
\hline 3 Dia & 0,0 & $\begin{array}{c}112,7 \pm 45,0 \\
{[85,4-140,0]}\end{array}$ & 0,0 & 0,0 \\
\hline $5^{\circ}$ Dia & $\begin{array}{l}10,7 \pm 16,3 \\
{[0,0-20,0]}\end{array}$ & $\begin{array}{c}7,5 \pm 8,0 \\
{[2,0-12,0]}\end{array}$ & 0,0 & 0,0 \\
\hline 70 Dia & $\begin{array}{c}60,6 \pm 41,0 \\
{[35,0-85,0]}\end{array}$ & $\begin{array}{c}64,0 \pm 66,0 \\
{[24,0-103,0]}\end{array}$ & 0,0 & $\begin{array}{c}46,0 \pm 38,2 \\
{[22,8-69,0]}\end{array}$ \\
\hline 10 Dia & $\begin{array}{c}87,3 \pm 80,0 \\
{[38,8-135,0]}\end{array}$ & $\begin{array}{l}218,2 \pm 287,8 \\
{[44,0-392,0]}\end{array}$ & 0,0 & $\begin{array}{r}138,5 \pm 211,4 \\
{[10,8-266,3]}\end{array}$ \\
\hline 15으 Dia & $\begin{array}{c}297,1 \pm 163,8 \\
{[198-396]}\end{array}$ & $\begin{array}{c}396,0 \pm 271,0 \\
{[232,0-560,0]}\end{array}$ & $\begin{array}{c}72,0 \pm 64,0 \\
{[33,4-110,7]}\end{array}$ & $\begin{array}{r}107,3 \pm 156,3 \\
{[13,0-201,8]}\end{array}$ \\
\hline 30 Dia & $\begin{array}{c}347,2 \pm 155,0 \\
{[253,6-440,7]}\end{array}$ & $\begin{array}{c}513,6 \pm 269,6 \\
{[350,7-676,5]}\end{array}$ & $\begin{array}{c}84,7 \pm 76,0 \\
{[39,0-130,0]}\end{array}$ & $\begin{array}{c}106,8 \pm 91,0 \\
{[51,0-162,0]}\end{array}$ \\
\hline
\end{tabular}

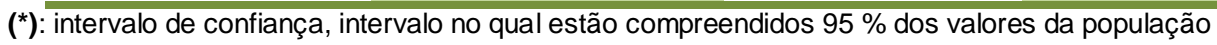




\subsection{Avaliação da influência do período colostral e do primeiro mês de lactação no proteinograma da secreção láctea de cabras}

A alta concentração de proteína no colostro assim como a diminuição acentuada dessa concentração com o passar dos dias observado no presente estudo estão de acordo com os relatos de estudos anteriores, em cabras (LINZELL; PEAKER, 1974; QUILES et al., 1991; ROTA et al., 1993; CHEN et al., 1998; LEVIEUX et al., 2002; ARGÜELLO et al., 2006; RUDOVSKY et al., 2008; YANG; CHEN; ZHANG, 2009) e em vacas (OYENIYI; HUNTER, 1978; HENG, 1999; MADSEN et al., 2004; SANT'ANA, 2004; SGARBIERI, 2005; TSIOULPAS; GRANDISON; LEWIS, 2007; RAIMONDO, et al.,2009)

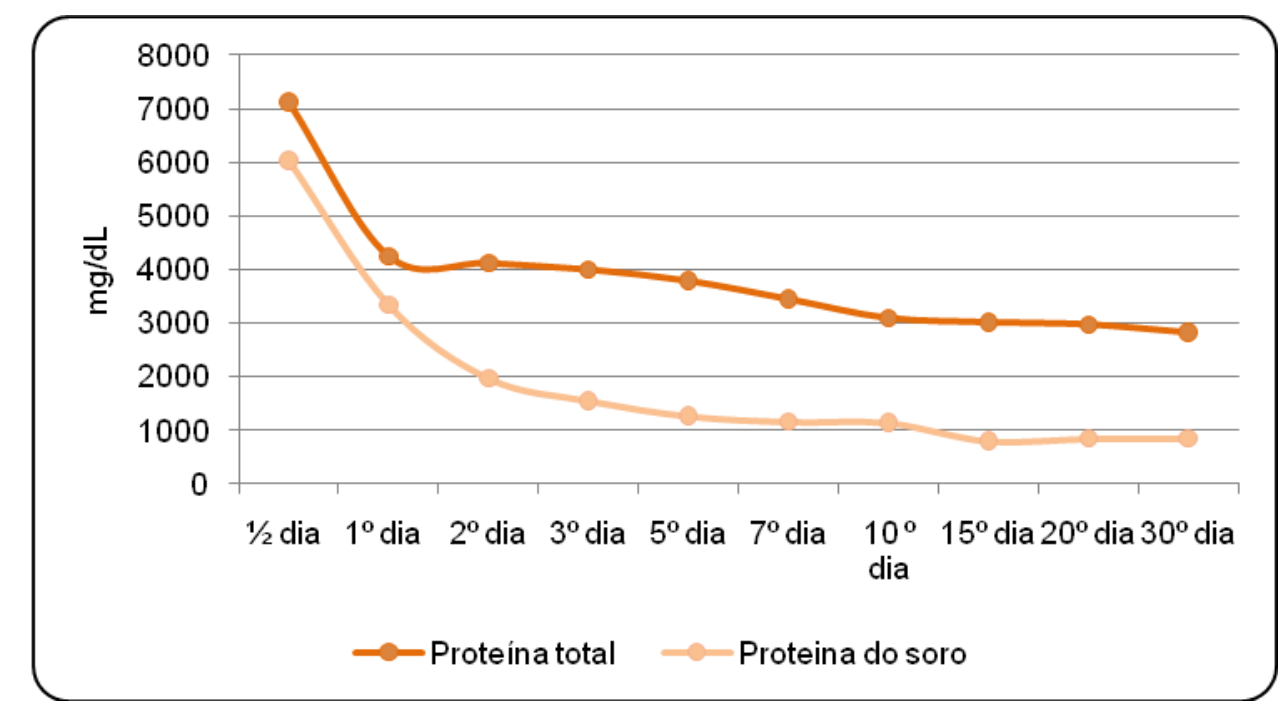

Legenda a,b,c - letras diferentes significam diferença estatística significante $(p \leq 0,05)$ - Teste t de Student

Gráfico 8 - Avaliação da influência da fase colostral e do primeiro mês de lactação nos teores de proteína total e proteína do soro lácteo de cabras Saanen - São Paulo - 2007 a 2010.

Os teores máximos de proteína total da secreção láctea foram encontrados nas primeiras 12 horas após o parto $(7.720,0 \pm 1.330,0 \mathrm{mg} / \mathrm{dL})$ decaindo rapidamente nas amostras colhidas entre 12 e 24 horas de lactação (4.250 $\pm 700 \mathrm{mg} / \mathrm{dL}$ ) e lentamente entre $\circ 2^{\circ}$ e $5^{\circ}$ dia de lactação. Os valores estabilizaram a partir do $7^{\circ}$ dia de lactação, variando entre $2.830,0 \pm 160,0 \mathrm{mg} / \mathrm{dL}$ e $3.450,0 \pm$ $390,0 \mathrm{mg} / \mathrm{dL}$ até o final do primeiro mês de lactação. A proteína do soro apresentou valor máximo nas primeiras 12 horas do pós-parto $(6.033,0 \pm 2.773,0 \mathrm{mg} / \mathrm{dL})$, 
decaindo rapidamente no $1^{\circ}$ dia de lactação $(3.342,0 \pm 2.100,0 \mathrm{mg} / \mathrm{dL})$ e se estabiliza a partir do $2^{\circ}$ dia chegando a $1.973,0 \pm 1.161,0 \mathrm{mg} / \mathrm{dL}$ no final do período estudado (Tabela 5 Gráfico 8).

No presente estudo as técnicas utilizadas para a avaliação da proteína total (radiação infravermelha) e do soro (método do Biureto) são diferentes, contudo, as concentrações obtidas estão de acordo com a maioria dos estudos anteriores e, podemos observar que nas primeiras 24 horas de lactação (Gráfico 8) o teor de proteína do soro representa praticamente o total de proteína da secreção e a partir do $5^{\circ}$ dia passa a corresponder cerca de $30 \%$ do total de proteína, concentração essa esperada na lactação plena. Esses resultados estão de acordo com os autores que afirmam existir no início da lactação o predomínio das proteínas do soro lácteo (OYENIYI; HUNTER, 1978; CHEN et al., 1998; HENG, 1999; SANT'ANA, 2004; SGARBIERI, 2005; CAJA; SALAMA; SUCH, 2006).

Observam-se na literatura compulsada controvérsias quanto ao predomínio protéico que ocorre na fase colostral, pois alguns autores atribuem às altas concentrações de proteína devido às proteínas do soro (OYENIYI; HUNTER, 1978; CHEN et al., 1998; HENG, 1999; SANT'ANA, 2004; SGARBIERI, 2005; CAJA; SALAMA; SUCH, 2006), enquanto que outros acreditam haver um aumento de todas as proteínas no colostro inclusive caseínas (QUILES et al., 1991; AULDIST et al., 1995; CUNNIGAN, 2004; MADSEN et al., 2004; TSIOULPAS; GRANDISON; LEWIS, 2007)

No fracionamento das proteínas durante a fase colostral e o primeiro mês de lactação de cabras da raça Saanen foram identificadas e quantificadas as seguintes frações protéicas: Lactoferrina $(84,0 \pm 4,0 \mathrm{kDa})$; Albumina $(66,0 \pm 2,0 \mathrm{kDa})$; Imunoglobulina de Cadeia Pesada (52,0 $\pm 2,0 \mathrm{KDa})$; Imunoglobulina de Cadeia Leve $(26,0 \pm 1,5 \mathrm{kDa}) ; \beta-\operatorname{Lg}(16,0 \pm 1,0 \mathrm{kDa})$ e $\alpha$-La $(12,0 \pm 0,65 \mathrm{kDa})$. Afora essas proteínas outras frações protéicas foram observadas, porém não puderam ser nomeadas sendo identificadas somente pelo peso molecular: proteínas com peso molecular entre 132 e $244 \mathrm{kDa}$ localizadas antes da fração da lactoferrina e proteínas com peso molecular entre 29 e $43 \mathrm{kDa}$ localizadas entre a imunoglobulina de cadeia pesada e imunoglobulina de cadeia leve (Gráfico 9). 

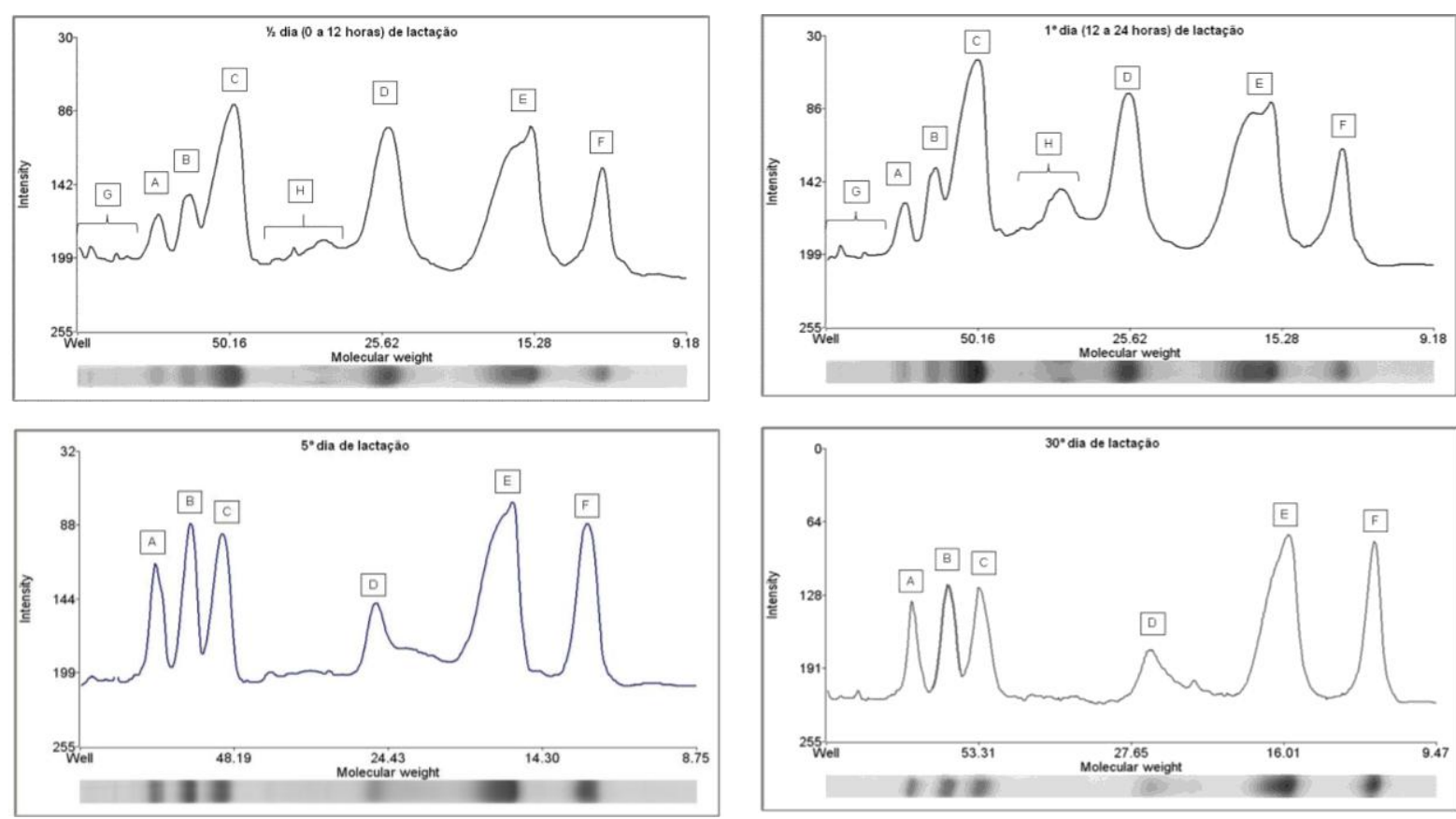

Legenda: A - lactoferrina; B - albumina sérica; C - imunoglobulina de cadeia pesada; D - imunoglobulina de cadeia leve; $\mathbf{E}$ - $\beta$-lactoglobulina; F - a-lactoalbumina; $\mathbf{G}$ - proteínas com peso molecular entre 132 e 244 $\mathrm{KDa} ; \mathbf{H}$ - proteínas com peso molecular entre 29 e $43 \mathrm{KDa}$

Gráfico 9 - Eletroforetograma das proteínas do soro lácteo de cabras Saanen durante a fase colostral e o primeiro mês de lactação, obtido através de eletroforese em gel de poliacrilamida (12\%) (SDS-PAGE). São Paulo 2008.

Durante o primeiro mês de lactação, conforme os resultados da presente pesquisa, os teores de todas as frações protéicas do soro são máximos na fase colostral. Sgarbieri (2004) afirmou que a elevada quantidade de proteínas do soro no colostro se deve não somente as imunoglobulinas, mas também as demais frações protéicas.

$\mathrm{Na}$ literatura compulsada não foram encontrados trabalhos avaliando todas as frações protéicas do soro lácteo durante a fase inicial da lactação, as pesquisas anteriores se dedicaram ao estudo de uma ou mais frações sendo que a principal proteína estudada foi a imunoglobulina.

A quantificação das imunoglobulinas foi realizada por diversos métodos: imunodifusão radial (OYENIYI; HUNTER, 1978; SANTOS et al., 1994; LEVIEUX et al., 2002; ARGÜELLO et al., 2006), ELISA (CHIGERWE et al., 2005; RUDOVSKY et al., 2008) eletroforese em gel de agarose (CHEN et al., 1998). Dentre esses métodos o ELISA é considerado o método mais preciso para a determinação da concentração de imunoglobulinas e é usado como método de referência (CHIGERWE et al., 2005). 
Apesar das diferentes classes de imunoglobulinas possuírem diferenças estruturais, todas são derivadas da mesma unidade básica que é composta por quatro cadeias, duas cadeias leves idênticas (23kD) e duas cadeias pesadas idênticas $(50-70 \mathrm{kD})$ unidas por pontes dissulfeto intercadeia e intracadeia (MAYER, [200-]). O uso de 2-mercaptoetanol durante o processamento das amostras submetidas à eletroforese em gel de poliacrilamida determinou a denaturação das proteínas com rompimento das pontes dissulfeto das imunoglobulinas e, como consequência, a divisão em cadeia pesada e cadeia leve. Com o rompimento dessas pontes, não foi possível identificar separadamente cada classe de imunoglobulina envolvida, pois as cadeias leves e pesadas possuem o mesmo peso molecular independentes da classe e são fracionadas na mesma posição nessa técnica de eletroforese. Quiles et al. (1991) utilizaram a técnica de eletroforese SDSPAGE, contudo os autores denominaram a fração de imunoglobulinas como "outras proteínas", não havendo menção do uso de mercaptoetanol ou sobre a quebra das pontes de dissulfeto com a divisão das imunoglobulinas em cadeia pesada e cadeia leve.

Nas primeiras 12 horas de lactação foram obtidos os maiores teores de imunoglobulinas (cadeia pesada 1.142,0 \pm 460,0 mg/dL e cadeia leve 1.431,0 \pm $879,0 \mathrm{mg} / \mathrm{dL}$ ) que decaem abruptamente na segunda colheita realizada no $1^{\circ}$ dia de lactação (576,0 $\pm 471,0 \mathrm{mg} / \mathrm{dL}$ cadeia pesada e 736,0 $\pm 678,0 \mathrm{mg} / \mathrm{dL}$ cadeia leve). No presente estudo foi observado que a partir do $5^{\circ}$ dia as concentrações de imunoglobulinas estabilizam chegando a 102,0 $\pm 32,0 \mathrm{mg} / \mathrm{dL}$ (cadeia pesada) e 99,0 $\pm 29,0$ (cadeia leve) no $30^{\circ}$ dia do pós-parto (Tabela 5 e Gráfico 11). Os valores médios de imunoglobulinas obtidos no presente estudo são menores do que os relatados na literatura compulsada, isso pode ser explicado devido às diferentes técnicas utilizadas para a determinação da concentração de imunoglobulinas no colostro. Apesar das diferenças numéricas, observa-se na literatura a mesmas tendências: teores máximos de imunoglobulinas obtidos no dia do parto, diminuição abrupta nas primeiras 24 horas de lactação (OYENIYI; HUNTER, 1978; QUILES et al., 1991; CHEN et al., 1998; HENG, 1999; LEVIEUX et al., 2002; ARGÜELLO et al., 2006; RUDOVSKY et al., 2008; ROCHA et al., 2009; YANG; CHEN; ZHANG, 2009) e tendência a estabilização a partir do $3^{\circ}$ dia de lactação (QUILES et al., 1991; CHEN 
et al., 1998; HENG, 1999; LEVIEUX, 1999; LEVIEUX et al., 2002; SGARBIERI, 2004; ROCHA et al., 2009; YANG; CHEN; ZHANG, 2009).

As principais proteínas do soro lácteo, $\beta$ - $\mathrm{Lg}$ e $\alpha$-La, são influenciadas pela fase colostral quando foram observadas altas concentrações concordando com os estudos anteriores (QUILES et al., 1991; LEVIEUX; OLLIER, 1999; LEVIEUX et al., 2002; BAROZA, 2007; ROCHA et al., 2009). Os valores médios de $\beta$ - $\mathrm{Lg}$ (Tabela $5 \mathrm{e}$ Gráfico 11), nas primeiras 12 horas de lactação foram iguais a 1.593,0 $\pm 909,0$ $\mathrm{mg} / \mathrm{dL}$ diminuindo abruptamente para $888,0 \pm 598,0 \mathrm{mg} / \mathrm{dL}$ nas 24 horas após o parto. Esses teores continuam decaindo rapidamente até 0 o dia de lactação quando estabilizam chegando a valores médios iguais a $323,0 \pm 48,0 \mathrm{mg} / \mathrm{dL}$ no $30^{\circ}$ dia de lactação. As médias obtidos para a fração $\alpha$-La são máximas nas primeiras 12 horas de lactação $(527,0 \pm 168,0 \mathrm{mg} / \mathrm{dL})$ e decaem progressivamente durante os 10 primeiros dias de lactação chegando a 160,0 $\pm 31,0 \mathrm{mg} / \mathrm{dL}$ nas amostras colhidas no $30^{\circ}$ dia de lactação (Tabela 5 e Gráfico 11).

$\mathrm{Na}$ presente pesquisa as concentrações de $\beta$ - Lg foram maiores do que as de $\alpha$-La durante todo o período estudado e o comportamento foi distinto, pois, os teores de $\beta$-Lg diminuem abruptamente nas primeiras 48 horas de lactação enquanto que a diminuição de $\alpha$-La é mais lenta e gradual durante todo o primeiro mês de lactação, essas observações estão de acordo com a literatura compulsada quando os trabalhos anteriores descreveram a diminuição abrupta da fração $\beta$-Lg nos primeiros dias após o parto, enquanto que a diminuição da fração $\alpha$-La é menor e mais gradual (PEREZ et al., 1990; QUILES et al., 1991; HENG, 1999; LEVIEUX; OLLIER, 1999; LEVIEUX et al., 2002; SGARBIERI, 2004).

$\mathrm{Na}$ avaliação do comportamento das proteínas fracionadas podemos observar mudança no predomínio protéico com o avanço da lactação (Gráfico 10). Nas primeiras 24 horas de lactação, ou seja, na fase colostral o predomínio maior é das imunoglobulinas, $41 \%$ nas primeiras 12 horas e $36 \%$ no $1^{\circ}$ dia, enquanto que a concentração das principais proteínas do soro lácteo, $\beta$ - Lg (12 horas: $26 \% ; 24$ horas: 27\%) e $\alpha$-La (12 horas: 9\%; 24 horas 12\%) somam juntas 35\% nas primeiras 12 horas de lactação e $39 \%$ no $1^{\circ}$ dia. Essas observações concordam com Oyeniyi e Hunter (1978) que encontraram nas 12 horas do pós-parto de vacas $78,3 \%$ de IgG e nas 24 horas após o parto 47,5\% de IgG, e com Lopez et al. (1988) que obtiveram $62,4 \%$ de imunoglobulinas no colostro de vacas. Chen et al. (1998) observaram no 
primeiro colostro coletado em cabras, cerca de $50 \%$ do total de proteínas como imunoglobulinas, proporção que decai para cerca de $30 \%$ da proteína total no final do primeiro dia.

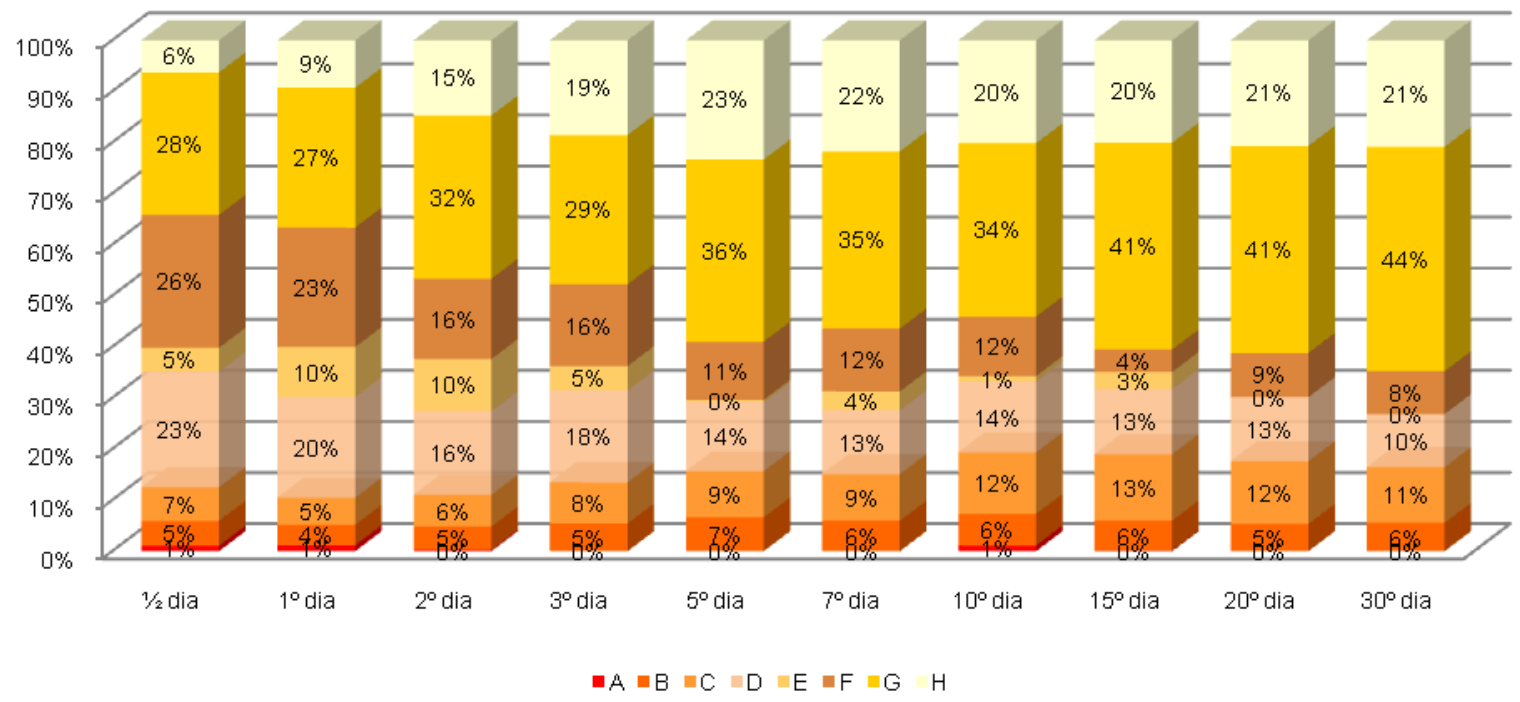

Legenda: A - 132 a 244 kDa; B - Lactoferrina; C - Albumina ; D - Ig pesada; E - 30 a 50 kDa; F - Ig leve ; G - $\beta$-Lg; $\mathbf{H}-\alpha-L a$

Gráfico 10 - Concentração (\%) das proteínas fracionadas do soro lácteo de cabras Saanen em relação à proteína do soro durante o primeiro mês de lactação obtida através da técnica de eletroforese em gel de poliacrilamida (12\%) (SDS-PAGE) - São Paulo 2007 a 2010.

No $5^{\circ}$ dia de lactação quando os teores médios de todas as frações estabilizam o predomínio das proteínas se modifica e as principais frações do soro lácteo, $\beta$-Lg (30\%) e $\alpha$-La (21\%) representam $51 \%$ das frações protéicas, enquanto que as cadeias pesada (14\%) e leve (15\%) das imunoglobulinas representam $29 \%$ das frações protéicas. No final do primeiro mês de lactação esse predomínio protéico é mantido, quando a glândula mamária está produzindo leite e não mais secreção colostral, as frações principais do soro lácteo, $\beta$-Lg e $\alpha$-La são a maioria $57 \%$ enquanto que as imunoglobulinas representam 23\% (Gráfico 10). De acordo com Chen et al. (1998) as frações $\alpha$-La e $\beta$-Lg são estáveis em cabras durante os primeiros cinco dias de lactação, sendo que as concentrações aumentam conforme diminuem os teores de imunoglobulinas chegando a $10 \%$ da proteína total no $5^{\circ}$ dia de lactação.

A albumina sérica (Tabela 5 e Gráfico 11) presente no soro lácteo de caprinos é influenciada pela fase colostral, pois foram observados nas primeiras 12 horas após o parto os teores máximos dessa fração iguais a 455,0 $\pm 259,0 \mathrm{mg} / \mathrm{dL}$ teores 
estes que diminuem abruptamente no $1^{\circ}$ dia de lactação $(202,0 \pm 151,0 \mathrm{mg} / \mathrm{dL})$ permanecendo estável até o final do primeiro mês de lactação $(98,0 \pm 29,0 \mathrm{mg} / \mathrm{dL})$. Esses resultados estão de acordo com trabalhos anteriores que observaram teores de albumina sérica elevados no início da lactação e diminuição abrupta durante os primeiros dias (PEREZ et al., 1989; HENG, 1999; LEVIEUX; OLLIER, 1999; LEVIEUX et al., 2002; SGARBIERI, 2004; BAROZA, 2007; ROCHA et al., 2009)

$O$ aumento dos teores lácteos de albumina reflete a inflamação do úbere no pós-parto e o aumento da permeabilidade vascular (PHILLIPPY; MCCARTHY, 1979). Segundo Shamay et al. (2005) existe síntese de albumina pelo tecido mamário, sendo que situações em que haja processo inflamatório como nas mamites e no período seco poderia haver substancial aumento da sua secreção pela glândula mamária.

As concentrações de albumina encontradas na presente pesquisa são semelhantes às obtidas por Perez et al. (1989), Heng (1999), Sgarbieri (2004) e Rocha et al. (2009) em vacas. Comparando os teores lácteos de albumina obtidos com os relatados para caprinos por Baroza (2007) observa-se discrepâncias que podem refletir interferências metodológicas na determinação dos valores de proteína no soro lácteo. Na presente pesquisa essas interferências foram minimizadas por uma série de medidas como centrifugação do soro lácteo a $16.000 \mathrm{~g}$ (13.000 rpm) por 20 minutos, eliminando a turbidez da amostra e evitando interferências na leitura da absorbância, bem como estabelecimento de curva padrão inter-relacionando as absorbâncias obtidas pelo método de Biureto e os valores de proteína obtidos pelo método de Kjeldhal.

Os teores de lactoferrina (Tabela 5 e Gráfico 11) são influenciados pela fase colostral, a concentração máxima foi observada nas primeiras 12 horas pós-parto $(418,0 \pm 277,0 \mathrm{mg} / \mathrm{dL})$ e diminui abruptamente no $1^{\circ}$ dia de lactação $(180,0 \pm 107,0$ $\mathrm{mg} / \mathrm{dL}$ ) permanecendo estável durante o restante do $1^{\circ}$ mês de lactação chegando a $73,0 \pm 34,0 \mathrm{mg} / \mathrm{dL}$ no $30^{\circ}$ dia. Essas observações estão de acordo com os estudos anteriores que referiram à maior concentração de lactoferrina no colostro e diminuição na sua concentração com o evoluir dos dias de lactação para vacas (SANCHEZ et al., 1988; TSUJl et al., 1990; HENG, 1999; YOSHIDA et al., 2000; BAROZA, 2007; HISS; MEYER; SAUERWEIN, 2008; ROCHA et al., 2009) e cabras (SANCHEZ et al., 1988; TSUJl et al., 1990; HENG, 1999; YOSHIDA et al., 2000; 
BAROZA, 2007; HISS; MEYER; SAUERWEIN, 2008; ROCHA et al., 2009). Entretanto existe discrepância nos teores lácteos de lactoferrina no colostro possivelmente devido às diferentes técnicas utilizadas (TSUJI et al., 1990; YOSHIDA et al., 2000) ou decorrentes a influência da espécie, pois segundo Masson e Heremans (1971) o colostro bovino contém concentrações menores de lactoferrina quando comparado com outras espécies.

Durante a fase colostral e o primeiro mês de lactação, além das proteínas normalmente observadas no soro lácteo de cabras foram observadas outras frações que não puderam ser nomeadas e foram apresentadas através do peso molecular. $A$ presença dessas outras frações no início da lactação pode ser justificada pelo aumento do incremento do fluxo sanguíneo que ocorre na glândula mamária na fase de preparação para o parto ocasionando inflamação fisiológica e o aumento da permeabilidade vascular com a passagem de proteínas séricas para a glândula mamária (PHILLIPPY; MCCARTHY, 1979; KOLB, 1984).

Nas primeiras 24 horas de lactação foram observadas frações protéicas antes da fração da lactoferrina com pesos moleculares que variaram entre 132 e $244 \mathrm{KDa}$ com a observação de até quatro frações dependendo da amostra colhida (pesos moleculares iguais a $246,0 \pm 8,5 \mathrm{KDa} ; 172,6 \pm 6,2 \mathrm{KDa} ; 136,4 \pm 3,7 \mathrm{KDa}$ e 117,7 \pm $1,0 \mathrm{KDa})$. Como a presença de todas essas frações não foi constante em todas as amostras optou-se pela soma das frações e apresentação dos resultados com frações protéicas entre 132 e $244 \mathrm{KDa}$. Os teores médios encontrados para proteínas com peso molecular entre 132 e $244 \mathrm{KDa}$ foi igual a 141,0 $\pm 70,0 \mathrm{mg} / \mathrm{dL}$ nas primeiras 12 horas de lactação, e $68,0 \pm 92,0 \mathrm{mg} / \mathrm{dL}$ nas amostras colhidas com 24 horas de lactação, após o término da fase colostral, ou seja após as primeiras 24 horas pós-parto essas frações não foram mais observadas (Tabela 5). Na literatura compulsada não foram encontrados trabalhos que citassem a presença dessas frações.

Outras duas novas frações protéicas foram observadas nos primeiros 15 dias de lactação: fração com peso molecular igual a 44,4 $\pm 6,0 \mathrm{mg} / \mathrm{dL}$ e fração com peso molecular igual a $32,3 \pm 0,84 \mathrm{mg} / \mathrm{dL}$, devido a presença dessas frações não serem constantes em todas as amostras analisadas optou-se pela apresentação do resultado da somatória dessas frações e nomeá-las como proteínas com peso molecular entre 30 e $50 \mathrm{KDa}$. Entre essas frações, pode estar presente a $\alpha-1$ - 
glicoproteína ácida que é uma proteína de fase aguda com peso molecular que varia entre 26 a $36 \mathrm{KDa}$ e foi encontrada em altas concentrações no colostro bovino em condições não patológicas (CECILIANI et al., 2005) contudo na presente pesquisa pelo delineamento experimental proposto não foi possível afirmar a presença dessa fração sendo necessária novas pesquisas. Essa fração protéica apresentou teor máximo nas primeiras 12 horas de lactação $(324,0 \pm 353,0 \mathrm{mg} / \mathrm{dL})$ teores estes que decaem rapidamente em 5 dias quando estabilizam chegando a $32,0 \pm 34,0 \mathrm{mg} / \mathrm{dL}$ no $15^{\circ}$ dia de lactação não sendo observadas nas amostras a partir de 20 dias de lactação (Tabela 5). De acordo com Ceciliani et al. (2005) a concentração de a-1glicoproteína ácida foi máxima nas primeiras 24 horas de lactação diminuindo com o passar dos dias e sendo de difícil detecção. 

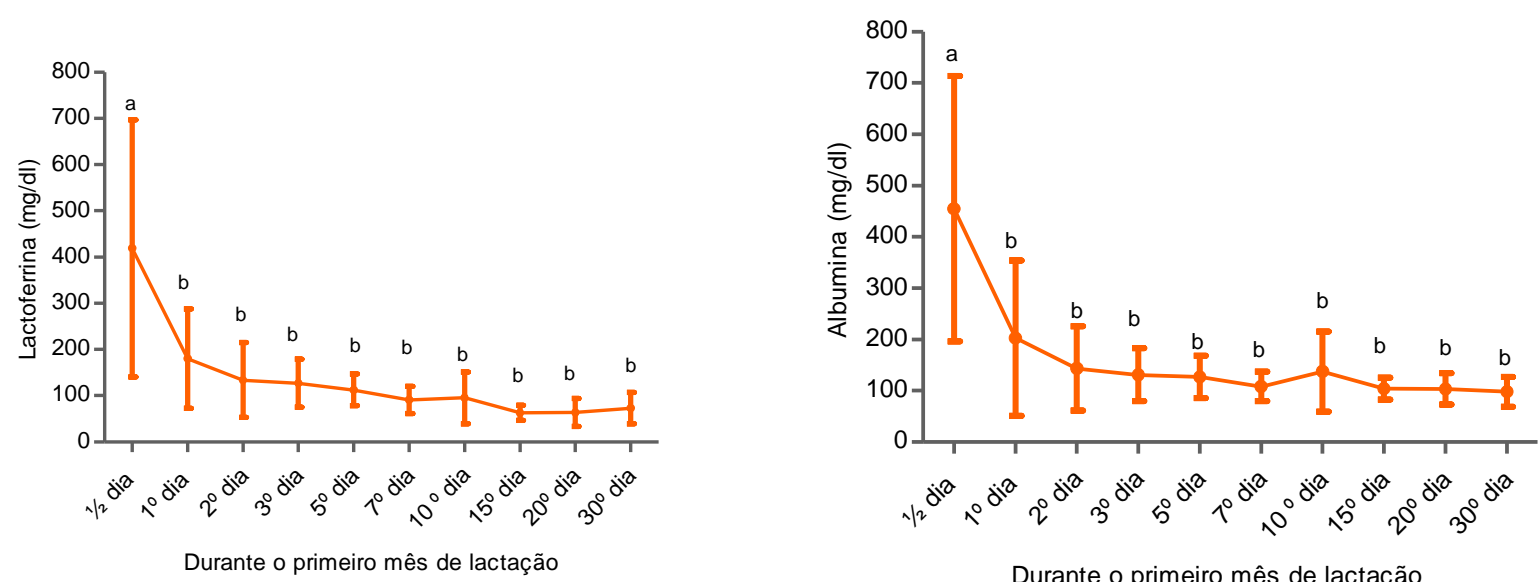

Durante o primeiro mês de lactação
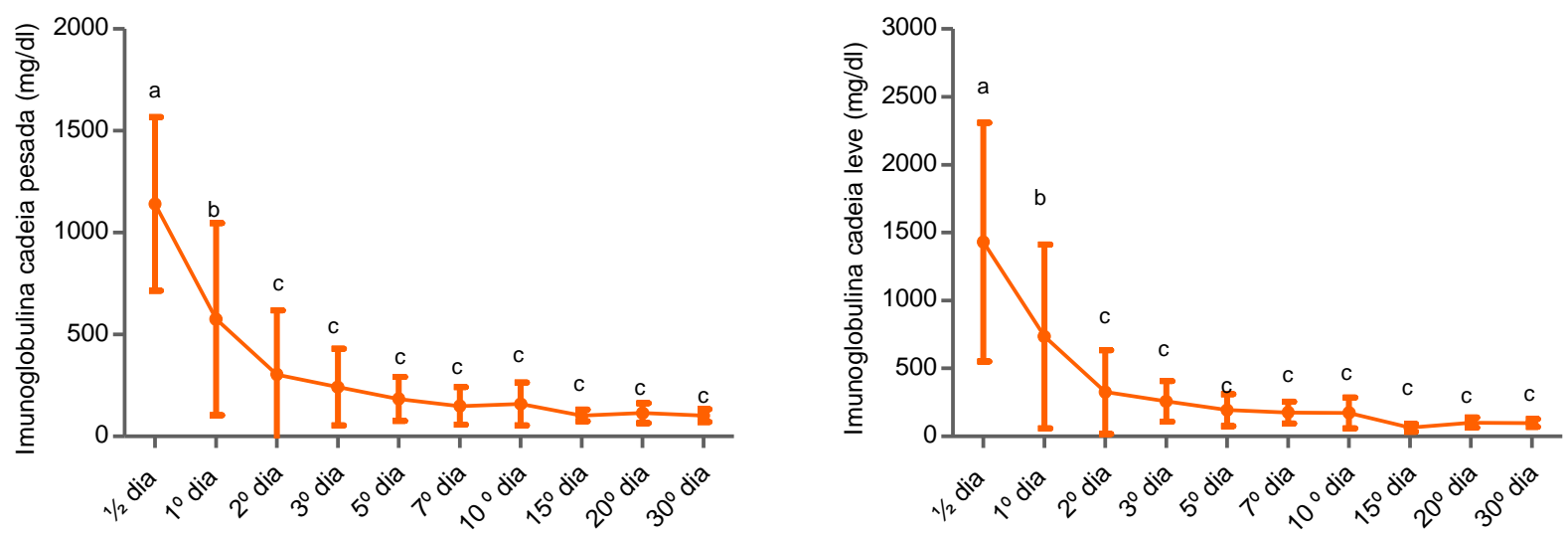

Durante o primeiro mês de lactação

Durante o primeiro mês de lactação
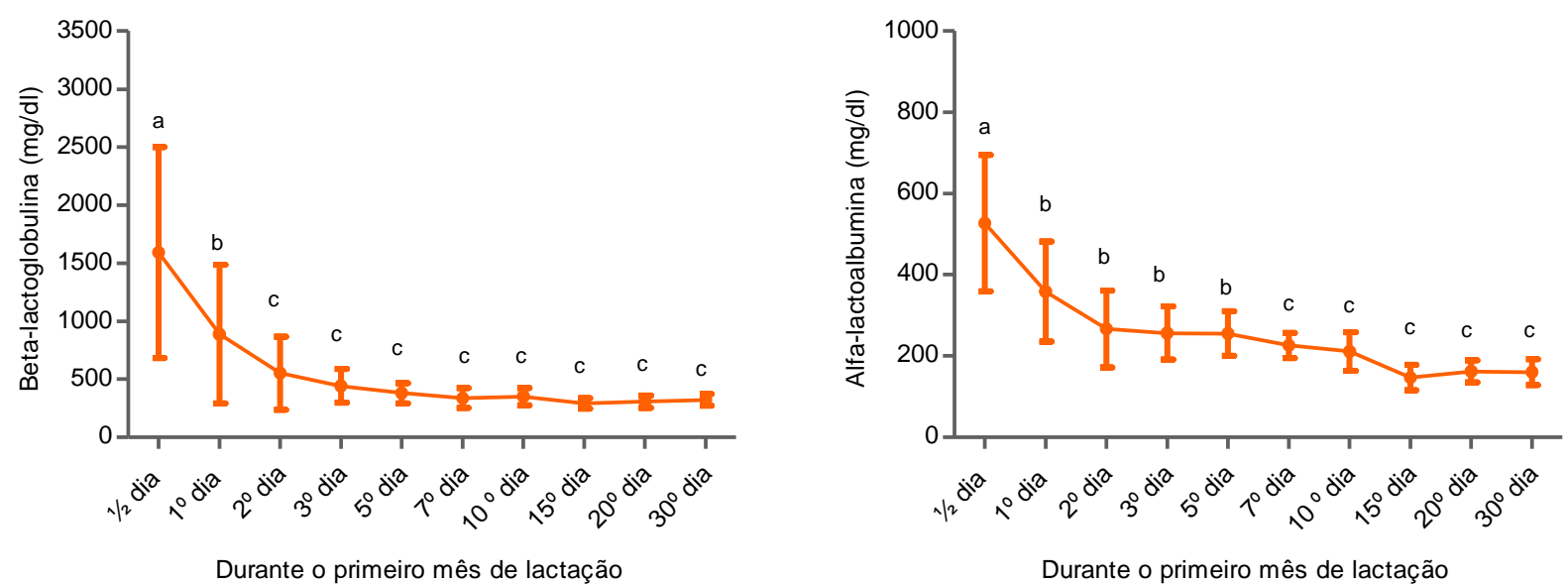

Legenda: a,b,c - letras diferentes significam diferença estatística significante $(p \leq 0,05)$ - Teste t de Student

Gráfico 11 - Avaliação da influência da fase colostral e do primeiro mês de lactação nas frações protéicas do soro lácteo de cabras Saanen - São Paulo - 2007 a 2010. 
Tabela 5 - Média, desvio padrão (DP), intervalo de confiança (IC 95\%) da proteína total da secreção láctea, da proteína do soro lácteo e das frações protéicas (fração de 132 a 244 kDa, lactoferrina; albumina; imunoglobulinas de cadeia pesada; fração de 30 a 50 kDa imunoglobulinas de cadeia leve; $\beta$-lactoglobulina; $\alpha$-lactoalbumina) durante o primeiro mês de lactação de cabras Saanen - São Paulo 2007 a 2010.

\begin{tabular}{|c|c|c|c|c|c|c|c|c|c|c|}
\hline \multirow[b]{2}{*}{$\begin{array}{l}\text { Dias de } \\
\text { lactação }\end{array}$} & \multicolumn{10}{|c|}{ PROTEINOGRAMA DO COLOSTRO DE CABRAS } \\
\hline & $\begin{array}{c}\text { Proteína total } \\
\text { Média } \pm \text { DP } \\
\text { [IC 95\%] }{ }^{*}\end{array}$ & $\begin{array}{c}\text { Proteína do soro } \\
\text { Média } \pm \text { DP } \\
\text { [IC 95\% }{ }^{*}\end{array}$ & $\begin{array}{c}132 \text { - } 244 \text { kDa } \\
\text { Média } \pm \text { DP } \\
{[\text { IC 95\%] * }}\end{array}$ & $\begin{array}{l}\text { Lactoferrina } \\
\text { Média } \pm \text { DP } \\
{[\text { IC 95\%] * }}\end{array}$ & $\begin{array}{l}\text { Albumina } \\
\text { Média } \pm \text { DP } \\
\text { [IC 95\%] }{ }^{*}\end{array}$ & $\begin{array}{l}\text { Ig Pesada } \\
\text { Média } \pm \text { DP } \\
{\left[\text { IC 95\%] }{ }^{*}\right.}\end{array}$ & $\begin{array}{c}30 \text { e } 50 \mathbf{~ k D a} \\
\text { Média } \pm \mathrm{DP} \\
{[\mathrm{IC} 95 \%]^{*}}\end{array}$ & $\begin{array}{c}\text { lg leve } \\
\text { Média } \pm \text { DP } \\
{[\text { IC 95\%] * }}\end{array}$ & $\begin{array}{c}\boldsymbol{\beta}-\mathbf{L g} \\
\text { Média } \pm \text { DP } \\
{\left[{ }^{\mathrm{IC}} \text { 95\%] }{ }^{*}\right.}\end{array}$ & $\begin{array}{c}\alpha-L a \\
\text { Média } \pm \text { DP } \\
{\left[\text { IC 95\%] }{ }^{*}\right.}\end{array}$ \\
\hline $1 / 2$ dia & $\begin{array}{c}7.120 \pm 1.330 \\
{[6.700-8.630]}\end{array}$ & $\begin{array}{c}6.033 \pm 2.773 \\
{[4.353-7.712]}\end{array}$ & $\begin{array}{c}141 \pm 70 \\
{[94-188]}\end{array}$ & $\begin{array}{c}418 \pm 277 \\
{[232-605]}\end{array}$ & $\begin{array}{c}455 \pm 259 \\
{[281-629]}\end{array}$ & $\begin{array}{l}1.142 \pm 426 \\
{[854-1.428]}\end{array}$ & $\begin{array}{l}324 \pm 353 \\
{[86-561]}\end{array}$ & $\begin{array}{c}1.431 \pm 879 \\
{[840-2.022]}\end{array}$ & $\begin{array}{c}1.593 \pm 909 \\
{[982-2.204]}\end{array}$ & $\begin{array}{c}527 \pm 168 \\
{[414-640]}\end{array}$ \\
\hline 10 dia & $\begin{array}{c}4.250 \pm 700 \\
{[3.640-4.760]}\end{array}$ & $\begin{array}{c}3.342 \pm 2.100 \\
{[2.007-4.676]}\end{array}$ & $\begin{array}{c}68 \pm 92 \\
{[6-130]}\end{array}$ & $\begin{array}{c}180 \pm 107 \\
{[108-252]}\end{array}$ & $\begin{array}{c}202 \pm 150 \\
{[100-304]}\end{array}$ & $\begin{array}{c}576 \pm 471 \\
{[259-892]}\end{array}$ & $\begin{array}{c}331 \pm 171 \\
{[216-446]}\end{array}$ & $\begin{array}{c}736 \pm 678 \\
{[280-1.191]}\end{array}$ & $\begin{array}{c}888 \pm 598 \\
{[486-1.290]}\end{array}$ & $\begin{array}{c}359 \pm 123 \\
{[276-441]}\end{array}$ \\
\hline $2^{\circ}$ dia & $\begin{array}{c}4.120 \pm 770 \\
{[3.450-4.890]}\end{array}$ & $\begin{array}{c}1.973 \pm 1.161 \\
{[1.235-2.710]}\end{array}$ & 0 & $\begin{array}{c}133 \pm 80 \\
{[80-188]}\end{array}$ & $\begin{array}{c}143 \pm 82 \\
{[88-199]}\end{array}$ & $\begin{array}{l}303 \pm 315 \\
{[91-515]}\end{array}$ & $\begin{array}{c}244 \pm 125 \\
{[160-328]}\end{array}$ & $\begin{array}{c}327 \pm 307 \\
{[120-533]}\end{array}$ & $\begin{array}{c}553 \pm 314 \\
{[342-765]}\end{array}$ & $\begin{array}{c}266 \pm 95 \\
{[203-330]}\end{array}$ \\
\hline 3ㅇ dia & $\begin{array}{c}4.000 \pm 530 \\
{[3.600-4.020]}\end{array}$ & $\begin{array}{c}1.555 \pm 505 \\
{[1.234-1.876]}\end{array}$ & 0 & $\begin{array}{c}127 \pm 52 \\
{[92-162]}\end{array}$ & $\begin{array}{c}131 \pm 51 \\
{[96-166]}\end{array}$ & $\begin{array}{c}242 \pm 187 \\
{[116-368]}\end{array}$ & $\begin{array}{c}95 \pm 104 \\
{[25-165]}\end{array}$ & $\begin{array}{c}258 \pm 150 \\
{[157-360]}\end{array}$ & $\begin{array}{c}443 \pm 143 \\
{[346-539]}\end{array}$ & $\begin{array}{c}256 \pm 65 \\
{[210-300]}\end{array}$ \\
\hline 5o dia & $\begin{array}{c}3.790 \pm 600 \\
{[3.240-4.310]}\end{array}$ & $\begin{array}{c}1.269 \pm 352 \\
{[1.045-1.493]}\end{array}$ & 0 & $\begin{array}{c}112 \pm 34 \\
{[89-135]}\end{array}$ & $\begin{array}{c}127 \pm 41 \\
{[99-154]}\end{array}$ & $\begin{array}{c}183 \pm 107 \\
{[111-256]}\end{array}$ & $\begin{array}{l}17 \pm 30 \\
{[0-37]}\end{array}$ & $\begin{array}{c}194 \pm 117 \\
{[115-272]}\end{array}$ & $\begin{array}{c}379 \pm 87 \\
{[321-438]}\end{array}$ & $\begin{array}{c}255 \pm 55 \\
{[218-292]}\end{array}$ \\
\hline $7^{\circ} \mathrm{dia}$ & $\begin{array}{c}3.450 \pm 390 \\
{[3.080-3.620]}\end{array}$ & $\begin{array}{c}1.162 \pm 318 \\
{[948-1.376]}\end{array}$ & 0 & $\begin{array}{c}91 \pm 29 \\
{[70-112]}\end{array}$ & $\begin{array}{l}108 \pm 29 \\
{[87-129]}\end{array}$ & $\begin{array}{c}149 \pm 92 \\
{[83-216]}\end{array}$ & $\begin{array}{c}72 \pm 75 \\
{[17-126]}\end{array}$ & $\begin{array}{c}176 \pm 80 \\
{[117-234]}\end{array}$ & $\begin{array}{c}338 \pm 86 \\
{[276-400]}\end{array}$ & $\begin{array}{c}226 \pm 31 \\
{[203-248]}\end{array}$ \\
\hline 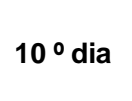 & $\begin{array}{c}3.100 \pm 260 \\
{[2.950-3.170]}\end{array}$ & $\begin{array}{c}1.145 \pm 353 \\
{[920-1.370]}\end{array}$ & 0 & $\begin{array}{c}95 \pm 56 \\
{[57-133]}\end{array}$ & $\begin{array}{c}137 \pm 78 \\
{[85-190]}\end{array}$ & $\begin{array}{l}160 \pm 105 \\
{[88-230]}\end{array}$ & $\begin{array}{l}18 \pm 42 \\
{[0-47]}\end{array}$ & $\begin{array}{l}173 \pm 113 \\
{[96-249]}\end{array}$ & $\begin{array}{c}350 \pm 75 \\
{[299-400]}\end{array}$ & $\begin{array}{c}211 \pm 47 \\
{[179-243]}\end{array}$ \\
\hline $15^{\circ}$ dia & $\begin{array}{c}3.020 \pm 190 \\
{[2.820-3.180]}\end{array}$ & $\begin{array}{c}805 \pm 119 \\
{[729-881]}\end{array}$ & 0 & $\begin{array}{c}63 \pm 16 \\
{[51-74]}\end{array}$ & $\begin{array}{c}104 \pm 21 \\
{[90-118]}\end{array}$ & $\begin{array}{c}103 \pm 28 \\
{[84-121]}\end{array}$ & $\begin{array}{l}32 \pm 34 \\
{[9-55]}\end{array}$ & $\begin{array}{c}62 \pm 28 \\
{[43-81]}\end{array}$ & $\begin{array}{c}292 \pm 45 \\
{[262-323]}\end{array}$ & $\begin{array}{c}147 \pm 31 \\
{[126-168]}\end{array}$ \\
\hline $20 \circ$ dia & $\begin{array}{c}2.980 \pm 140 \\
{[2.860-3.130]}\end{array}$ & $\begin{array}{c}850 \pm 192 \\
{[728-973]}\end{array}$ & 0 & $\begin{array}{c}63 \pm 30 \\
{[43-84]}\end{array}$ & $\begin{array}{c}104 \pm 30 \\
{[83-124]}\end{array}$ & $\begin{array}{c}113 \pm 48 \\
{[81-146]}\end{array}$ & 0 & $\begin{array}{c}100 \pm 38 \\
{[75-126]}\end{array}$ & $\begin{array}{c}306 \pm 54 \\
{[270-342]}\end{array}$ & $\begin{array}{c}162 \pm 27 \\
{[144-180]}\end{array}$ \\
\hline $30 \circ$ dia & $\begin{array}{c}2.830 \pm 160 \\
{[2.690-2.980]}\end{array}$ & $\begin{array}{c}856 \pm 178 \\
{[743-970]}\end{array}$ & 0 & $\begin{array}{c}73 \pm 34 \\
{[50-95]}\end{array}$ & $\begin{array}{c}98 \pm 29 \\
{[78-117]}\end{array}$ & $\begin{array}{c}102 \pm 32 \\
{[81-124]}\end{array}$ & 0 & $\begin{array}{c}99 \pm 29 \\
{[79-119]}\end{array}$ & $\begin{array}{c}323 \pm 48 \\
{[290-355]}\end{array}$ & $\begin{array}{c}160 \pm 31 \\
{[140-182]}\end{array}$ \\
\hline
\end{tabular}

Legenda: (*): intervalo de confiança, intervalo no qual estão compreendidos $95 \%$ dos valores da população

Número de glândulas mamárias analisadas por dia: 11 


\subsection{Proteinograma do leite de cabras durante a lactação plena}

O proteinograma do leite de cabras durante a lactação plena, através da análise da proteína total, proteína do soro lácteo e frações protéicas do soro lácteo objetivou determinar os valores de referência e analisar as influências da fase de lactação e número de lactações durante esse período.

\subsubsection{Valores de referência do proteinograma do leite de cabras}

Considerando-se as 160 amostras de leite colhidas entre 15 e 210 dias, ou seja, durante a lactação plena de cabras da raça Saanen, verificou-se que o teor médio de proteína total do leite foi igual a $2.997 \pm 347,0 \mathrm{mg} / \mathrm{dL}$ e proteína total do soro lácteo igual a 938,0 $\pm 227,0 \mathrm{mg} / \mathrm{dL}$. Com base nos intervalos de confiança obtidos para estas variáveis, recomenda-se que seja utilizado como referência para os teores de proteína total valores entre 2.940,0 e $3.050 \mathrm{mg} / \mathrm{dL}$ e proteína do soro lácteo valores entre 903,0 e 973,0 mg/dL para cabras em lactação plena.

Esses resultados concordam com as concentrações de proteína total no leite de cabras obtidas em estudos anteriores, variando entre 2.830 e $3.500 \mathrm{mg} / \mathrm{dL}$, independente da raça, região ou técnica utilizada em sua determinação. (ROTA et al., 1993; ZENG; ESCOBAR, 1995; BENEDET; CARVALHO, 1996; SUNG; WU; WANG, 1999; FERNANDES, 2002; GOMES et al., 2004; MOATSOU et al., 2008), exceto os resultados encontrados para cabras da raça Nubiana por Zeng e Escobar (1995) iguais a $3.600 \mathrm{mg} / \mathrm{dL}$ e, Sung, Wu e Wang (1999) iguais a $4.230 \mathrm{mg} / \mathrm{dL}$ e para a raça local da Grécia estudada por Moatsou et al. (2008) igual a $3.880 \mathrm{mg} / \mathrm{dL}$ que foram mais altos.

$\mathrm{Na}$ literatura compulsada somente o estudo de Storry et al. (1983) determinaram o teores de proteína do soro de cabras (entre 370 e $700 \mathrm{mg} / \mathrm{dL}$ ) que foi menor do que o obtido no presente estudo. Contudo os resultados obtidos na presente pesquisa foram semelhantes aos observados em vacas holandesas por Sant'Ana e Birgel (2007) iguais a $1.071 \pm 133,0 \mathrm{mg} / \mathrm{dL}$ e maiores do que os referidos 
por Raimondo, Miyiashiro, Birgel Junior (2009) iguais a $640 \pm 250 \mathrm{mg} / \mathrm{dL}$ em vacas Jersey. Cabe ressaltar que a técnica utilizada na presente pesquisa para a obtenção do soro lácteo foi a mesma utilizada por Raimondo, Miyiashiro, Birgel Junior (2009) o que faz concluir que o leite de cabras possui maior concentração de proteínas do soro lácteo quando comparado com o leite de vacas.

No fracionamento das proteínas durante a lactação plena de cabras da raça Saanen (Gráfico 12) foram identificadas e quantificadas as seguintes frações: Lactoferrina (84,0 \pm 4,0 kDa); Albumina sérica (66,0 $\pm 2,0 \mathrm{kDa})$; Imunoglobulina de Cadeia Pesada (52,0 $\pm 2,0 \mathrm{kDa})$; Imunoglobulina de Cadeia Leve $(26,0 \pm 1,5 \mathrm{kDa})$; $\beta$-lactoglobulina $(16,0 \pm 1,0 \mathrm{kDa})$ e $\alpha$-lactoalbumina $(12,0 \pm 0,65 \mathrm{kDa})$.

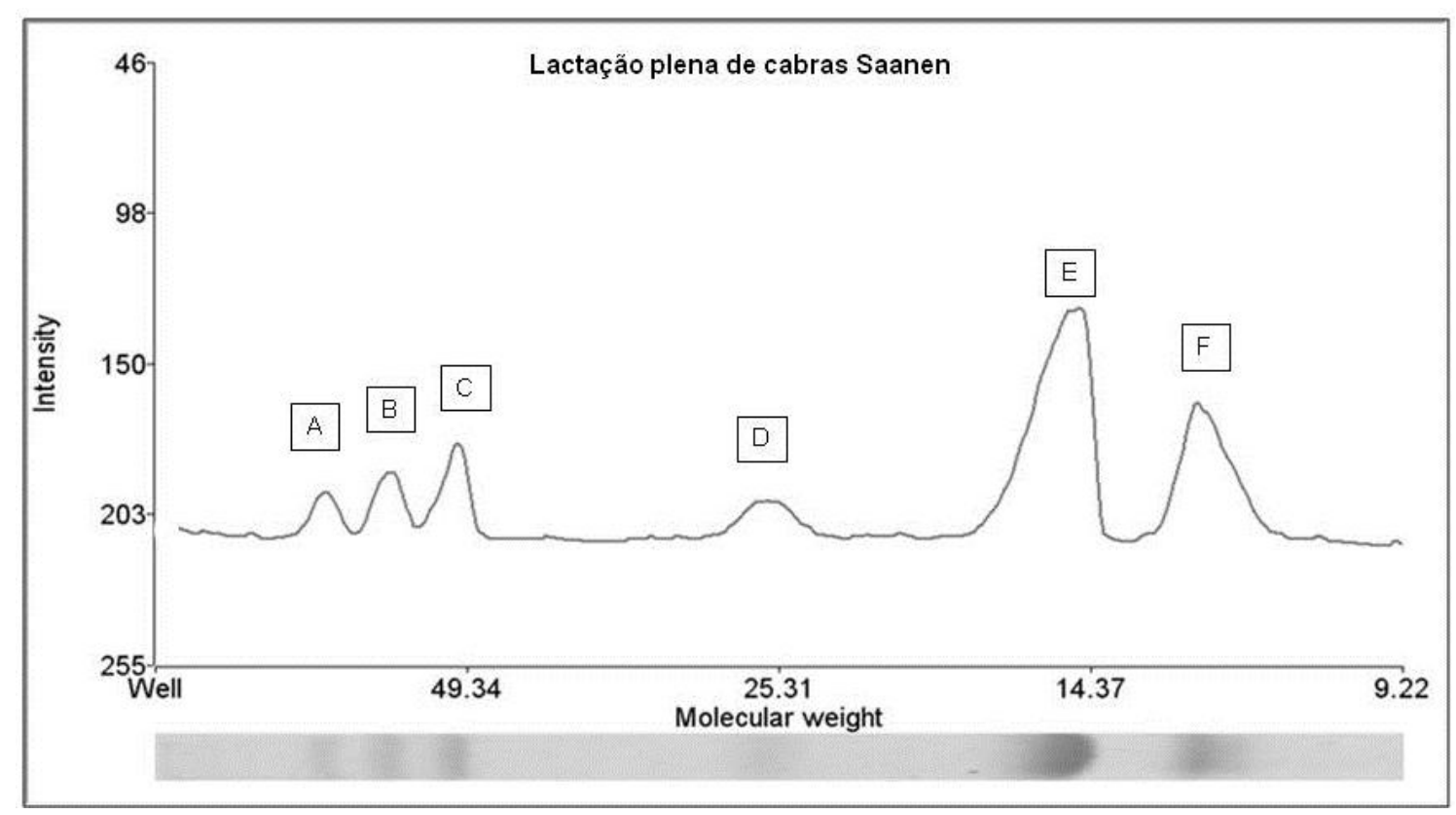

Legenda: A - lactoferrina; B - albumina sérica; C - imunoglobulina de cadeia pesada; D - imunoglobulina de cadeia leve; $\mathbf{E}$ - $\beta$-lactoglobulina; $\mathbf{F}$ - $\alpha$-lactoalbumina.

Gráfico 12 - Eletroforetograma das proteínas do soro lácteo de cabras Saanen durante a lactação plena, obtido através de eletroforese em gel de poliacrilamida $(12 \%)$ (SDS-PAGE) - São Paulo - 2007 a 2010.

As concentrações de lactoferrina e albumina sérica (Tabela 6) obtidas no presente estudo quando comparadas com as referidas na literatura, observamos que foram semelhantes às obtidas por Sant'Ana e Birgel (2007) em vacas Holandesas e menores do que as obtidas em vacas Jersey por Raimondo, Miyiashiro, Birgel Junior (2009). 
Tabela 6 - Média, desvio padrão, intervalo de confiança (95\%) das frações protéicas (lactoferrina; albumina; imunoglobulinas de cadeia pesada e cadeia leve; $\beta$-lactoglobulina; $\alpha$-lactoalbumina) do soro de leite de cabras da raça Saanen durante a lactação plena - São Paulo - 2007 a 2010.

\begin{tabular}{lcc}
\hline Proteinograma & $\begin{array}{c}\text { Média } \pm \text { Desvio Padrão } \\
(\mathbf{m g} / \mathbf{d L})\end{array}$ & $\begin{array}{c}\text { Intervalo de Confiança } \\
(\mathbf{m g} / \mathbf{d L})\end{array}$ \\
\hline Lactoferrina & $72,5 \pm 28,5$ & $68,0-77,0$ \\
Albumina sérica & $92,7 \pm 28,2$ & $88,0-97,0$ \\
Ig pesada & $98,1 \pm 31,0$ & $93,3-103,0$ \\
Ig leve & $139,3 \pm 42,5$ & $132,7-146,0$ \\
$\boldsymbol{\beta}$-Lg & $314,2 \pm 97,4$ & $299,0-329,0$ \\
$\boldsymbol{\alpha}$-La & $221,0 \pm 53,2$ & $213,0-229,5$ \\
\hline
\end{tabular}

O uso de 2-mercaptoetanol durante o processamento das amostras submetidas à eletroforese SDS-PAGE na presente pesquisa determina denaturação das proteínas com rompimento das pontes dissulfeto e, como conseqüência, a divisão das imunoglobulinas em cadeia pesada e cadeia leve. Houve dificuldades na comparação dos resultados, pois o estudo da concentração de imunoglobulinas no leite pleno é escasso e somente Raimondo, Miyiashiro, Birgel Junior (2009) obtiveram em vacas a divisão em cadeia leve e pesada (cadeia pesada - 40,0 $\pm 20,0$ $\mathrm{mg} / \mathrm{dL}$ e cadeia leve - 80,0 $\pm 60,0$ ), resultados que foram menores quando comparados com os obtidos no presente estudo $(98,0 \pm 31,0 \mathrm{mg} / \mathrm{dL}$ cadeia pesada e 139,3 \pm 42,5 mg/dL cadeia leve) (Gráfico 12 e Tabela 6).

Os resultados obtidos para as principais proteínas do soro, $\beta$-Lg e $\alpha$-La (Tabela 6), são controversos quando comparados com estudos anteriores, pois a concentração de $\beta$-Lg foi menor e a de $\alpha$-La foi maior do que os resultados obtidos por Calffin, Poutrel e Rainard (1985) em vacas, menores que os obtidos por Sant'Ana e Birgel (2007) em vacas e maiores do que os obtidos por Storry et al. (1983) e Raimondo, Miyiashiro, Birgel Junior (2009) e concordam com os resultados de Moatsou et al. (2008) obtidos em cabras locais da Grécia e em cabras de raças internacionais.

Segundo Raimondo, Miyiashiro e Birgel Junior (2009) a discrepância dos valores obtidos para os teores de $\beta$-Lg e $\alpha$-La em sua pesquisa quando comparados com os obtidos por Sant'Ana e Birgel (2007), mesmo sendo utilizada a mesma técnica de eletroforese SDS-PAGE, foi devido a diferença na metodologia utilizada na determinação da concentração de proteína do soro que é a base do cálculo das 
frações protéicas. O método utilizado por Raimondo, Miyiashiro, Birgel Junior (2009) conforme citado anteriormente, foi o mesmo utilizado neste estudo, sendo assim podemos observar que o soro de leite caprino contém maiores concentração de $\beta$ Lg, $\alpha$-La, imunoglobulina, lactoferrina e albumina sérica em relação ao soro de leite de vacas Jersey.

$\mathrm{Na}$ literatura compulsada os estudos comparativos das frações de proteínas do soro de leite em cabras e vacas são escassos e não há um consenso entre os resultados. Jonke et al. (1964) através da capacidade de promover a síntese de lactose determinaram que $\alpha$-La no soro de leite de cabras igual a $223 \mathrm{mg} / \mathrm{dL}$ é maior do que em vaca ( $120 \mathrm{mg} / \mathrm{dL}$ ) e as concentrações de $\beta$-Lg são semelhantes em vacas e cabras. Ley e Jeness (1970) através da técnica de Imunoensaio observaram também concentrações maiores de $\alpha$-La em cabras $(220 \mathrm{mg} / \mathrm{dL}$ ) quando comparadas com vacas $(120 \mathrm{mg} / \mathrm{dL})$, entretanto Storry et al. (1983) encontraram valores semelhantes de $\alpha$-La em cabras e vacas enquanto que o teor de $\beta$-Lg foi o dobro em cabras quando comparado com vacas.

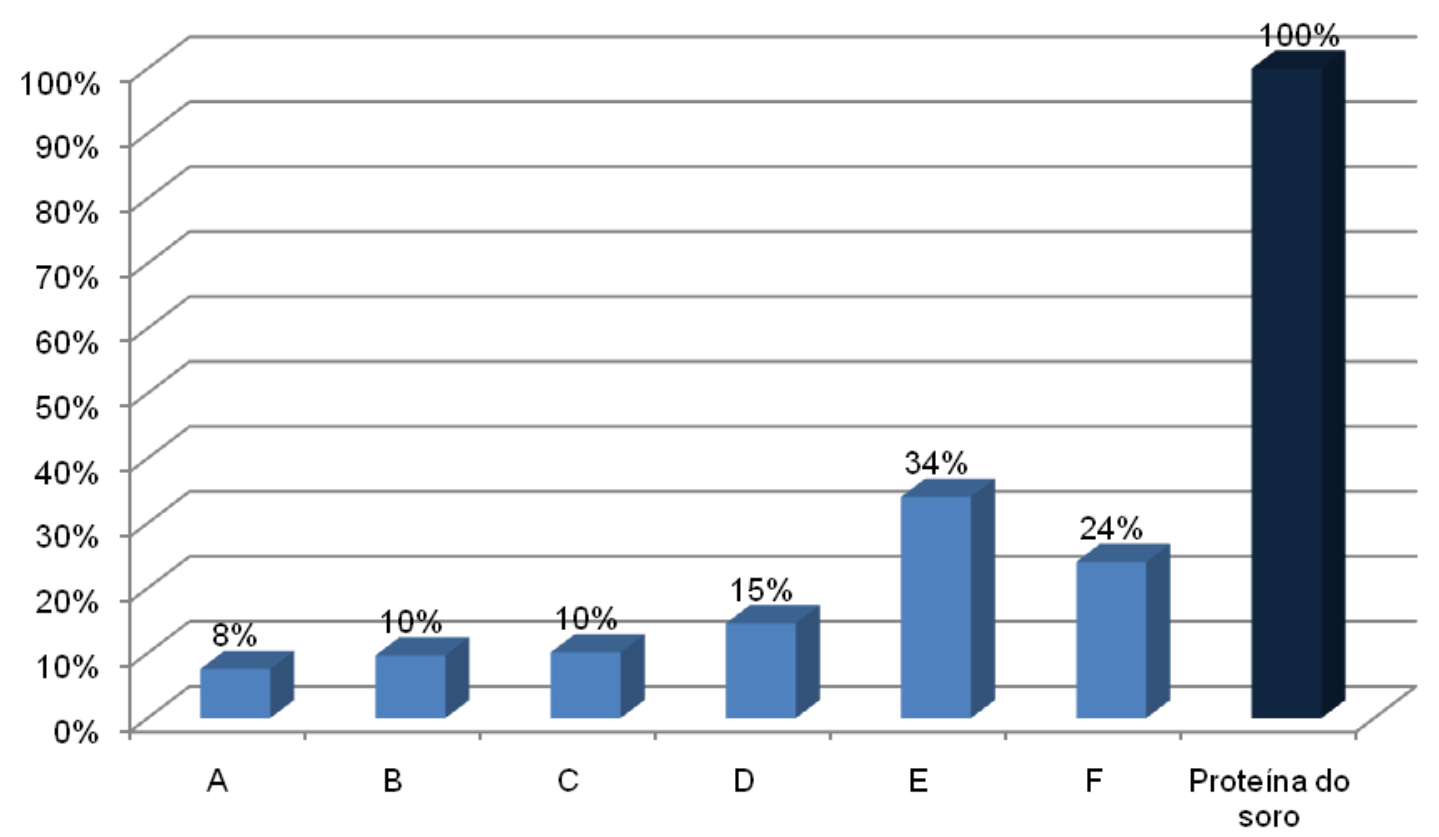

Legenda: A - Lactoferrina; B - Albumina ; C - Ig pesada; D - Ig leve ; E - $\beta$-Lg; F - a-La

Gráfico 13 - Concentração (\%) das proteínas fracionadas do soro lácteo de cabras Saanen em relação à proteína do soro durante lactação plena, obtida através da técnica de eletroforese em gel de poliacrilamida (12\%) (SDS-PAGE) - São Paulo 2007 a 2010. 
Durante a lactação plena de cabras da raça Saanen as principais proteínas do soro lácteo foram a $\beta$-Lg (33\%) e $\alpha$-La (24\%) que juntas corresponderam a $57 \%$ de todas as proteínas do soro lácteo. Dentre as proteínas de origem plasmática observou-se que as imunoglobulinas representaram $25 \%$ das proteínas encontradas no soro lácteo, enquanto que os percentuais de lactoferrina e albumina foram respectivamente $8 \%$ e $10 \%$ do total de proteína do soro lácteo observado em mamas sadias durante a lactação plena (Gráfico 13).

A percentagem de $\beta$-Lg foi menor e a de albumina sérica (10\%) foi o dobro no soro de leite de cabras em relação ao soro de vacas obtidas por Raimondo, Miyiashiro, Birgel Junior (2009), contudo a distribuição das demais frações protéicas foi semelhante em vacas e cabras

4.3.2 Influência da fase de lactação no proteinograma do leite de cabras

No presente estudo foi possível avaliar a influência da fase de lactação nas concentrações de proteína total, proteína do soro e nas frações protéicas do soro (Tabela 7 e Gráficos 14 e 15). As maiores concentrações foram obtidas nos primeiros quinze dias de lactação, período que envolve a fase colostral (primeiras 24 horas pós-parto). A análise de correlação de Spearman demonstrou que as frações de proteínas do soro apresentam relação positiva, isto é, quando a concentração de uma proteína aumenta, as outras aumentam consecutivamente.

O valor máximo de proteína total foi obtido em amostras colhidas nos primeiros 15 dias de lactação $(3.524,0 \pm 610,0 \mathrm{mg} / \mathrm{dL})$. Após 15 dias os teores estabilizam e voltam a aumentar no $4^{\circ}$ mês de lactação $(3.130,0 \pm 271,0 \mathrm{mg} / \mathrm{dL})$. Essas observações concordam com os estudos de Zeng e Escobar (1995) em cabras, que apresentaram concentrações maiores de proteína total no início e no final da lactação. E são controversas as concentrações de proteína total obtidas no leite de cabras por Fernandes (2002); Macciotta et al. (2005); Mioč et al. (2008) e Strzałkowska et al. (2009) que aumentaram com o evoluir da lactação, contudo os mencionados autores não avaliaram animais durante a fase colostral. Em outro 
estudo também contrário aos resultados da presente pesquisa, Gomes et al. (2004) não observaram influência da fase de lactação na proteína total do leite de cabras.

A proteína do soro lácteo se comportou da mesma maneira, apresentando teores máximos nas amostras colhidas entre 0 e 15 dias de lactação (1.136,0 \pm $305,6 \mathrm{mg} / \mathrm{dL}$ ), voltando a aumentar no final da lactação, porém com menos oscilações do que a proteína total.

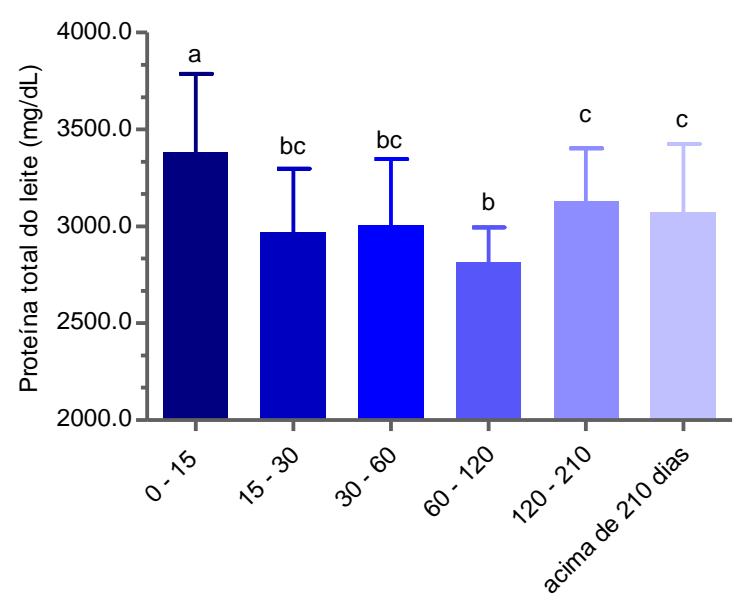

Dias de lactação

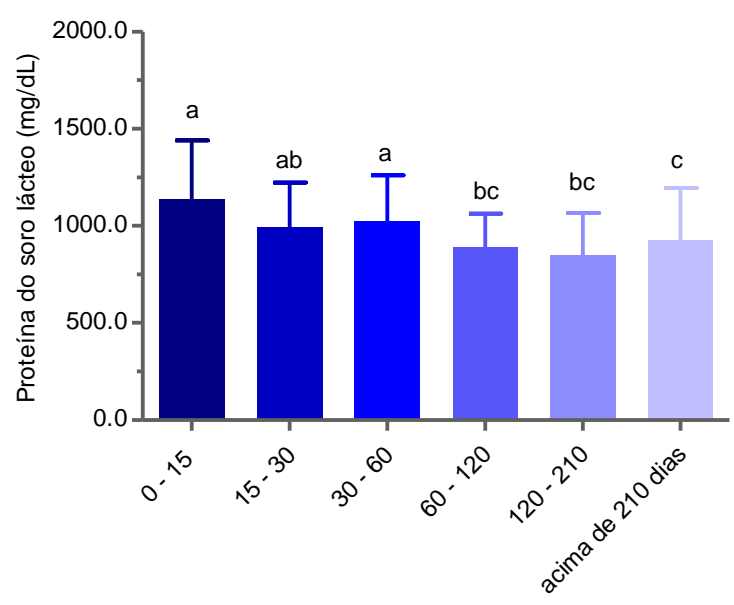

Dias de lactação

Legenda: a,b,c - letras diferentes significam diferença estatística significante $(p \leq 0,05)$ - Teste de Bonferroni

Gráfico 14 - Avaliação da influência da fase de lactação nos teores de proteína total do leite e proteína do soro lácteo de cabras Saanen - São Paulo - 2007 a 2010.

A concentração de proteína do soro lácteo também foi máxima no período inicial e final de lactação conforme os resultados obtidos por Auldist et al. (1995), Sant'Ana e Birgel (2007) e Raimondo, Miyiashiro, Birgel Junior (2009), contudo cabe ressaltar que os referidos estudos avaliaram a influência da lactação em vacas e que na literatura compulsada não foram encontrados trabalhos com a espécie caprina.

Os teores de lactoferrina (Tabela 7 e Gráfico 15) foram mais altos nos primeiros 15 dias de lactação $(88,54 \pm 33,5 \mathrm{mg} / \mathrm{dL})$ permanecendo sem variações até o final da lactação $(84,0 \pm 29,5 \mathrm{mg} / \mathrm{dL})$. Sant'Ana e Birgel, (2007) observaram que os teores de lactoferrina não variaram ao longo da lactação de vacas. Rainard, Poutrel e Caffin (1982) e Cheng et al. (2008) em vacas e Hiss, Meyer e Sauerwein (2008) em cabras observaram um aumento nos teores de lactoferrina com o evoluir da lactação. Os resultados da presente pesquisa discordam de Raimondo, Miyiashiro e Birgel Junior (2009) que observaram diminuição na lactoferrina ao longo da lactação de vacas Jersey. 
A albumina sérica (Tabela 7 e Gráfico 15) presente no soro lácteo de caprinos diminui gradativamente com pequena variação ao longo da lactação. A concentração de albumina sérica foi maior nos primeiros 15 dias de lactação $(110,4 \pm 39,0 \mathrm{mg} / \mathrm{dL})$ permanecendo estável até o $2^{\circ}$ mês de lactação quando decai para 85,0 $\pm 22,0$ $\mathrm{mg} / \mathrm{dL}$ entre 60 e 120 dias de lactação continuando estável até o final do período estudado. Esses resultados concordam com Quiles et al. (1994) que observou diminuição dos teores de albumina entre $85^{\circ}$ e $210^{\circ}$ em cabras e com Raimondo, Miyiashiro e Birgel Junior (2009) que também observou diminuição nos teores de albumina ao longo da lactação de vacas, contrariamente aos resultados obtidos por Poutrel, Caffin e Rainard (1983) que observaram um aumento dessas concentrações em relação ao estágio de lactação de vacas. Larson e Kendall (1957) e Sant’Ana e Birgel (2007) avaliando a concentração de albumina em vacas observaram que não houve variação ao longo da lactação.

Como referido anteriormente, na presente pesquisa devido ao preparo das amostras houve a divisão das imunoglobulinas em cadeia pesada e cadeia leve. $O$ teor máximo de imunoglobulinas de cadeia pesada $(141,0 \pm 45,0 \mathrm{mg} / \mathrm{dL})$ e cadeia leve (161,0 $\pm 67,5 \mathrm{mg} / \mathrm{dL})$ foi observado nos primeiros 15 dias de lactação devido a fase colostral (Tabela 7 e Gráfico 15). A partir do 15으 dia de lactação os teores de imunoglobulina de cadeia pesada permanecem estáveis ao longo da lactação com a menor concentração $(86,2 \pm 31,0 \mathrm{mg} / \mathrm{dL})$ obtida entre 120 e 210 dias de lactação, enquanto que a cadeia leve apresentou oscilações, após os primeiros 15 dias, decai abruptamente entre 15 e 30 dias de lactação quando foi obtido o menor valor (120,0 $\pm 36,4 \mathrm{mg} / \mathrm{dL})$, que volta a subir entre 30 e 60 dias $(155,0 \pm 47,0 \mathrm{mg} / \mathrm{dL})$ (Tabela 7 e Gráfico 15). Novamente houve dificuldade na comparação dos resultados da presente pesquisa com estudos anteriores, pois a maioria deles abordam a fase inicial da lactação, e somente o estudo de Raimondo, Miyiashiro e Birgel Junior (2009) obtiveram as duas cadeias de imunoglobulinas através da técnica de eletroforese SDS-PAGE. Contudo os resultados estão de acordo com Larson e Kendall (1957) que observaram concentrações menores de imunoglobulinas no final da lactação de vacas e com Caffin, Poutrel e Rainard (1983); Caffin e Poutrel (1988); Sant'Ana e Birgel (2007) e Raimondo, Miyiashiro e Birgel Junior (2009) que observaram teores maiores de imunoglobulinas no início da lactação.

Os valores médios de $\beta$ - $\mathrm{Lg}$ (Tabela 7 e Gráfico 15) diminuem ao longo da lactação e foram maiores durante os primeiros dois meses, quando foi observada a 
concentração máxima entre 15 e 30 dias de lactação $(395,3 \pm 97,6 \mathrm{mg} / \mathrm{dL})$. Após o primeiro mês de lactação os teores dessa proteína decaem chegando ao valor mínimo nas amostras obtidas entre 120 e 210 dias $(252,4 \pm 65,7 \mathrm{mg} / \mathrm{dL})$. $\mathrm{Na}$ literatura compulsada a influência da fase de lactação nas concentrações de $\beta$-Lg é controversa, pois alguns estudos observaram um aumento dessas concentrações com o evoluir da lactação de vacas (CAFFIN; POUTREL; RAINARD, 1985) e cabras (QUILES et al., 1994), enquanto que no estudo conduzido por Larson e Kendall (1957) em vacas, as concentrações de $\beta$-Lg não variaram ao longo da lactação.

Os resultados da presente pesquisa estão de acordo com os obtidos por Ostersen, Foldager e Hermansen (1997) durante a lactação de vacas que afirmaram que as mudanças no teor de $\beta$ - $\mathrm{Lg}$ acompanham a concentração de proteína, diminuindo durante a lactação com concentração mínima observada no meio da lactação e com Sant'Ana e Birgel (2007) e Raimondo, Miyiashiro e Birgel Junior (2009) que também observaram diminuição dos teores de $\beta$ - Lg ao longo da lactação de vacas. Ostersen, Foldager e Hermansen (1997) e Sant'Ana e Birgel (2007) encontraram um aumento dos resultados de $\beta$ - $\operatorname{~g~no~final~da~lactação,~na~presente~}$ pesquisa existiu tendência de aumento desses teores no período final.

A análise dos resultados obtidos para a fração de $\alpha$-La (Tabela 7 e Gráfico 15) demonstrou que houve pouca variação nas concentrações dessa proteína ao longo da lactação. O maior valor foi obtido entre 30 e 60 dias de lactação $(243,3 \pm 56,4$ $\mathrm{mg} / \mathrm{dL}$ ) e foram significativamente maiores quando comparados com os obtidos entre 15 e 30 dias de lactação quando foi observado o menor valor para essa proteína (199,0 $\pm 59,7 \mathrm{mg} / \mathrm{dL})$.

$\mathrm{Na}$ literatura compulsada, assim como para $\beta-\mathrm{Lg}$, houveram controversas nos resultados obtidos para a $\alpha$-La. Larson e Kendall (1957) observaram em vacas que a a-La atinge a produção máxima aos 30 dias diminuindo posteriormente com o evoluir da lactação, Caffin, Poutrel e Rainard (1985); Ostersen, Foldager e Hermansen (1997) e Raimondo, Miyiashiro e Birgel Junior (2009) também observaram diminuição nos teores de $\alpha$-La ao longo da lactação de cabras, os resultados da presente pesquisa estão de acordo com os referidos autores, pois, os resultados maiores foram obtidos no início da lactação. Durante a lactação de cabras os resultados da presente pesquisa são contrários aos obtidos por Quiles et al. (1994) que encontraram um aumento nas concentrações de $\alpha$-La entre o $85^{\circ}$ e $210^{\circ}$ dias de lactação. Os resultados obtidos por Sant'Ana e Birgel (2007) em vacas Holandesas 
concordam com o presente estudo, pois foi também observado que a concentração de $\alpha$-La apresentou pequena variação no decorrer da lactação.

Afora as principais frações do soro lácteo obtidas através da eletroforese SDS-PAGE, nas amostras colhidas durante os primeiros 15 dias de lactação, foram observadas novas frações localizadas entre a cadeia pesada e leve de imunoglobulinas com peso molecular variando entre 30 e $50 \mathrm{kDa}$, essas proteínas não puderam ser nomeadas e a soma de suas frações apresentaram concentrações médias iguais a $67,0 \pm 87,5 \mathrm{mg} / \mathrm{dL}$. A presença dessas frações é atribuída as alterações fisiológicas que ocorrem na glândula mamária durante a fase colostral, pois nas amostras colhidas após 15 dias de lactação elas não foram observadas. 


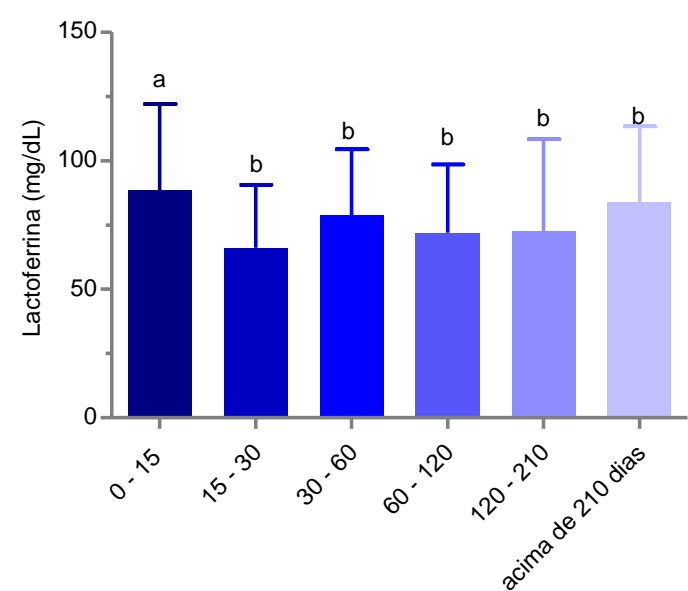

Dias de lactação

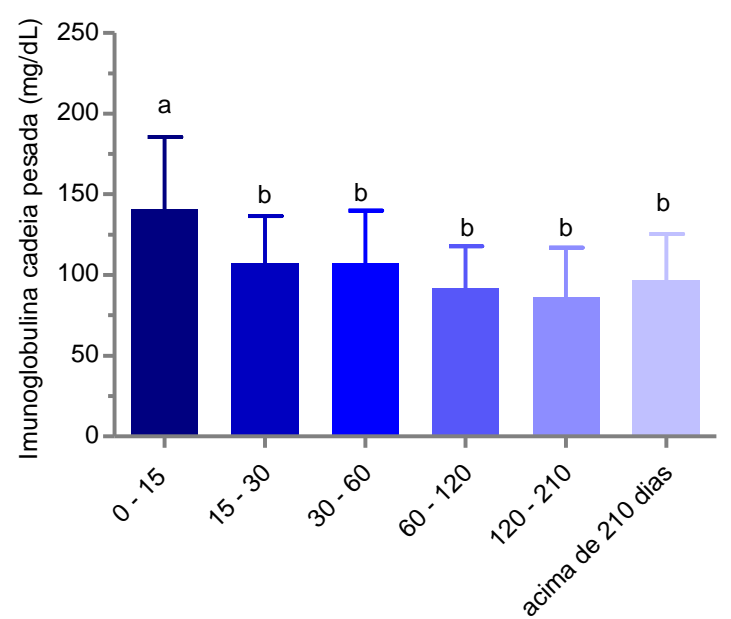

Dias de lactação

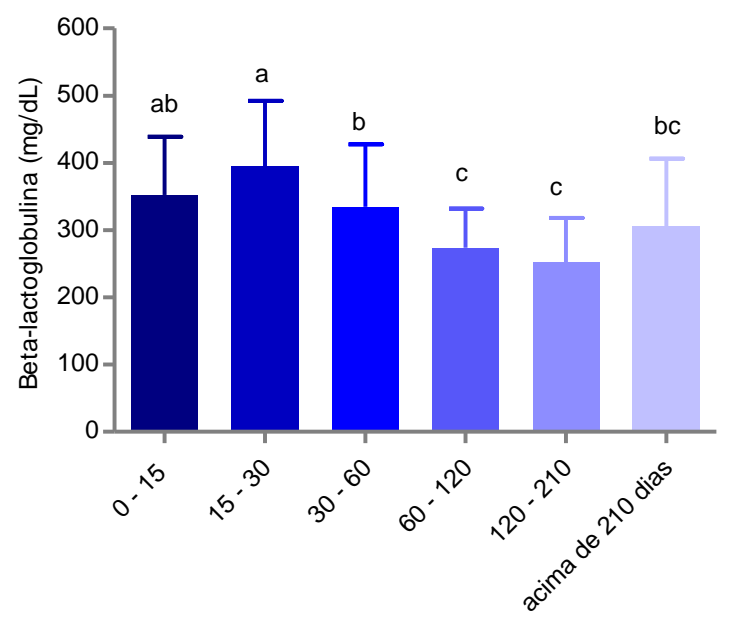

Dias de lactação

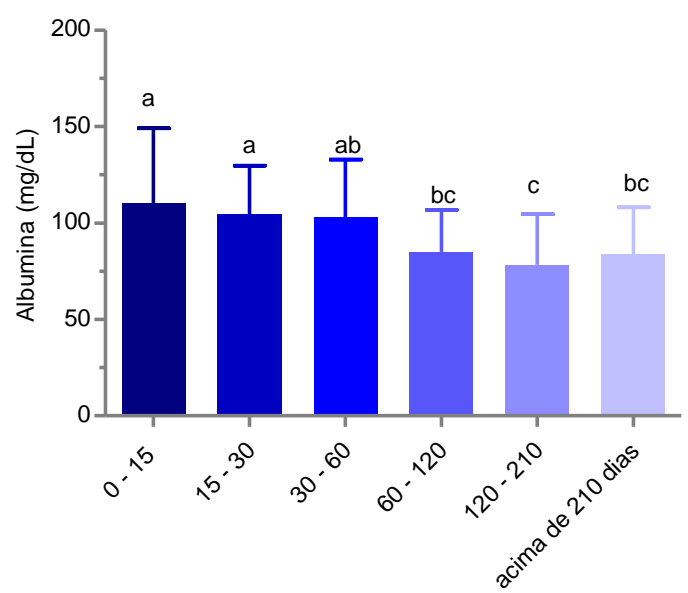

Dias de lactação

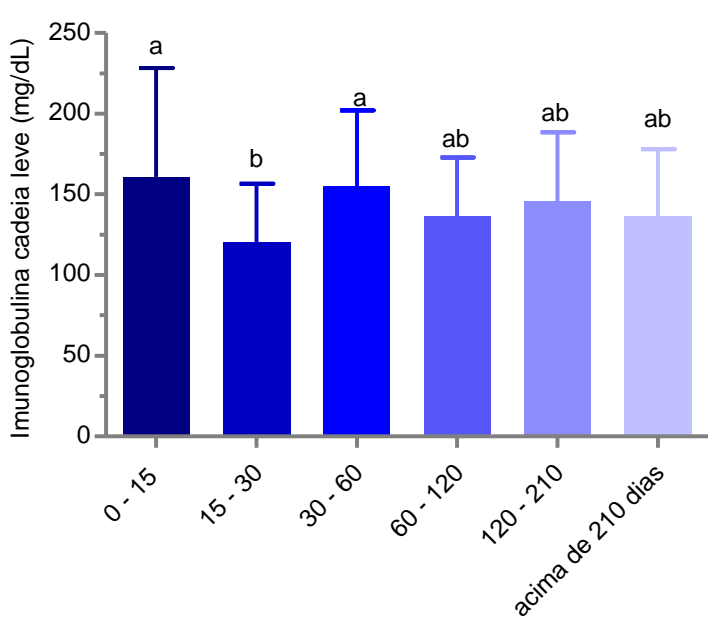

Dias de lactação

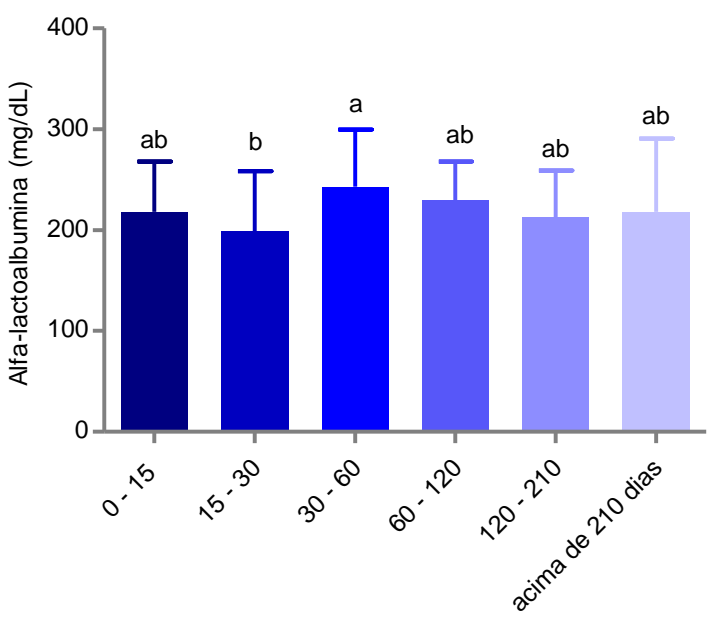

Dias de lactação

a,b,c - letras diferentes significam diferença estatística significante $(p \leq 0,05)$ - Teste de Bonferroni

Gráfico 15 - Avaliação da influência da fase de lactação nas frações protéicas do soro lácteo do leite de cabras Saanen - São Paulo - 2007 a 2010. 
4.3.3 Resultados da influência do número de lactações no proteinograma do leite de cabras

A análise dos resultados (Tabela 8 e Gráfico 16) demonstrou que o teor de proteína total do leite de cabras não variou em relação ao número de lactações, essas observações estão de acordo com estudos anteriores (PRASAD; SENGAR, 2002; CIAPPESONI et al., 2004; RODRIGUES et al., 2006; ZAHRADDEEN; BUTSWAT; MBAP, 2007). Entretanto discordam das pesquisas realizadas por Kala e Prakash (1990); Carnicella et al. (2008) e Mioč et al. (2008) que observaram em cabras primíparas teores de proteína maiores, que diminuem com o aumento do número de paridade e com os resultados de Macciotta et al. (2005) e Bhosale et al. (2009) que observaram que a concentração de proteína total do leite de cabras aumenta conforme aumentam o número de lactações.
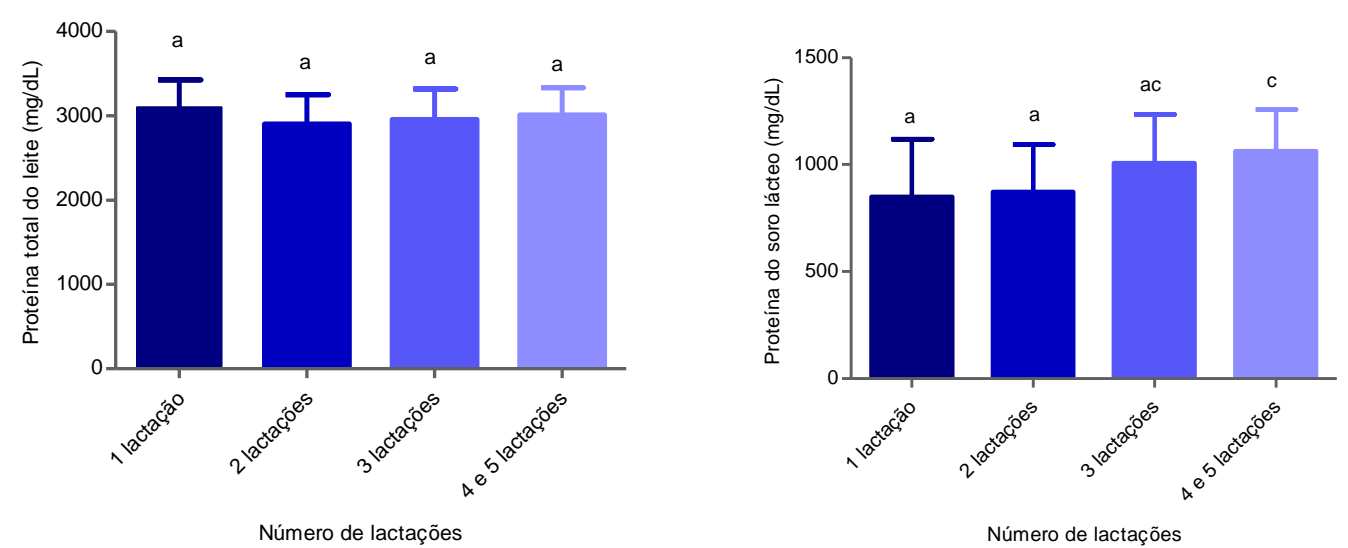

a,b,c - letras diferentes significam diferença estatística significante $(p \leq 0,05)$ - Teste de Bonferroni

Gráfico 16 - Avaliação da influência do número de lactações nos teores de proteína total do leite e proteína do soro lácteo de cabras Saanen - São Paulo - 2007 a 2010

Os teores de proteína do soro lácteo foram menores em amostras de cabras primíparas $(849,3 \pm 268,4 \mathrm{mg} / \mathrm{dL})$ e 2 lactações $(841,3 \pm 222,7 \mathrm{mg} / \mathrm{dL})$ quando comparados com cabras com $3(1.006,0 \pm 227,5 \mathrm{mg} / \mathrm{dL}), 4$ e 5 lactações $(1.063,0 \pm$ $195,4 \mathrm{mg} / \mathrm{dL}$ ). $\mathrm{Na}$ literatura compulsada não foram encontradas pesquisas que avaliassem a concentração da proteína do soro de leite em cabras durante a lactação plena. Levando-se em consideração o valor de referencia para proteína do soro lácteo durante a lactação plena de cabras obtido na presente pesquisa, entre 903,0 e $973,0 \mathrm{mg} / \mathrm{dL}$, podemos observar que cabras primíparas e de $2^{-}$lactação, 
apresentaram concentrações de proteína do soro lácteo inferiores que pode ser justificado pela imaturidade do tecido mamário dessas cabras durante a primeira lactação. Esses resultados discordam dos obtidos por Sant'Ana (2004) que não observou influência do número de parições na concentração de proteína do soro de leite de vacas holandesas.

A menor concentração de proteína do soro lácteo em cabras de primeira cria está relacionada com as menores concentrações das frações protéicas desse soro lácteo conforme a análise dos resultados. Os teores de lactoferrina, albumina sérica, imunoglobulinas e $\beta$-Lg, são menores em cabras de primeira lactação e aumentam conforme aumentam as parições (Tabela 8 e Gráfico 17). Essa influência pode ser explicada devido ao metabolismo na glândula mamária durante a lactação de primíparas ser diferente, pois os nutrientes são divididos entre a lactação e o crescimento contínuo do animal (WATHES et al., 2007), além disso, ocorre um desenvolvimento progressivo do tecido mamário secretor e do sistema vascular das primíparas (SAFAYI et al., 2010).

Os teores de lactoferrina (Tabela 8 e Gráfico 17) são maiores no soro lácteo de cabras com 4 e 5 lactações $(94,7 \pm 31,5 \mathrm{mg} / \mathrm{dL})$ quando comparados com os teores de cabras com até 3 lactações, sendo que as primíparas apresentaram o menor teor de lactoferrina $(66,7 \pm 27,5 \mathrm{mg} / \mathrm{dL})$, concordando com o estudo de Barth et al. (2010) que obteve em cabras primíparas teores menores de lactoferrina quando comparados com cabras multíparas. Essas observações discordam dos estudos de Rainard, Poutrel e Caffin (1982), Cheng et al. (2008) e Sant'Ana (2004) que não observaram influência do número de lactações nas concentrações de lactoferrina no leite de vacas. Contudo Cheng et al. (2008) apesar de não observarem diferenças afirmaram que as concentrações de lactoferrina tendem a ser maiores em vacas com mais de 3 lactações quando comparadas com vacas entre 1 e 2 lactações.

A menor concentração de albumina sérica no soro lácteo foi observada em cabras com uma lactação $(79,0 \pm 28,4 \mathrm{mg} / \mathrm{dL})$ e o teor máximo de albumina sérica foi obtida no soro lácteo de cabras com 4 e 5 lactações $(102,0 \pm 22,0 \mathrm{mg} / \mathrm{dL})$. Os resultados da presente pesquisa não concordam com os resultados obtidos na literatura compulsada que também foram controversos entre si, pois Poutrel, Caffin e Rainard (1983) observaram que o número de lactações não influenciou os teores de albumina sérica no leite de vacas, enquanto que no estudo realizado por Sant'Ana 
(2004) a concentração de albumina sérica nas vacas com duas ou três lactações foi menor do que em primíparas e vacas com mais de 4 lactações.

Novamente houve dificuldade na comparação dos resultados obtidos para a fração de imunoglobulina devido, a divisão em cadeia pesada e cadeia leve. Avaliando os resultados do presente estudo foi possível concluir que o soro lácteo de cabras com mais de 3 lactações possuem teores maiores de imunoglobulinas ( 3 lactações : cadeia pesada: 103,0 $\pm 24,3 \mathrm{mg} / \mathrm{dL}$ e cadeia leve: $158,0 \pm 42,0 \mathrm{mg} / \mathrm{dL} ; 4$ e 5 lactações: cadeia pesada: $116,0 \pm 28,0 \mathrm{mg} / \mathrm{dL}$ e cadeia leve: $166,5,0 \pm 44,0$ $\mathrm{mg} / \mathrm{dL}$ ) quando comparadas com o soro lácteo de cabras entre 1 e 2 lactações. Essas observações estão de acordo com o comportamento observado por Caffin, Poutrel e Rainard (1983) que observaram concentração de $\operatorname{lgG}_{1}$ sem alterações durante as três primeiras lactações e um aumento em vacas com quatro lactações e com Caffin e Poutrel (1988) que observaram concentração de $\operatorname{lgG}_{2}$ menor nas duas primeiras lactações. Contudo as concentrações encontradas nos referidos estudos em vacas através da técnica de imunodifusão radial foram inferiores aos resultados obtidos na presente pesquisa.

As concentração de imunoglobulinas obtidas na presente pesquisa discordam das encontradas por Sant'Ana (2004). Apesar do referido estudo utilizar a técnica de eletroforese SDS-PAGE somente uma fração de imunoglobulina foi fracionada pela autora que obteve concentrações menores de imunoglobulina em vacas de $2^{\mathrm{a}}$ ou $3^{\mathrm{a}}$ lactações $(117,96 \pm 34,75 \mathrm{mg} / \mathrm{dL})$ quando comparadas com os valores obtidos no leite de primíparas e vacas com mais de 4 lactações.

Em relação as frações de $\beta$-Lg e $\alpha$-La a análise dos resultados demonstrou que somente a fração $\beta$-Lg é influenciada pelo número de lactações. A concentração de $\beta$ - $\mathrm{Lg}$ (Tabela 8 e Gráfico 17), foi menor em cabras de primeira cria $(264,3 \pm 90,7$ $\mathrm{mg} / \mathrm{dL})$ quando comparados com os teores do soro lácteo de cabras com $3(334,7 \pm$ $102,0 \mathrm{mg} / \mathrm{dL}$ ), 4 e 5 lactações (334,7 $\pm 75,2 \mathrm{mg} / \mathrm{dL}$ ), discordando de Caffin, Poutrel e Rainard (1985) que observaram um aumento na concentração de $\beta$-Lg na segunda lactação e com Sant'Ana (2004) que descreveu que a fração de $\beta$-Lg foi mais alta em primíparas, e vacas com duas ou três lactações e diminui em animais com mais de quatro lactações.

O estudo da influência do número de lactações nos teores de $\alpha$-La no soro lácteo de cabras da raça Saanen (Tabela 8 e Gráfico 17) demonstrou não haver 
alteração independente do número de lactações das cabras avaliadas. Discordando dos resultados de Caffin, Poutrel e Rainard (1985) e Sant'Ana (2004).

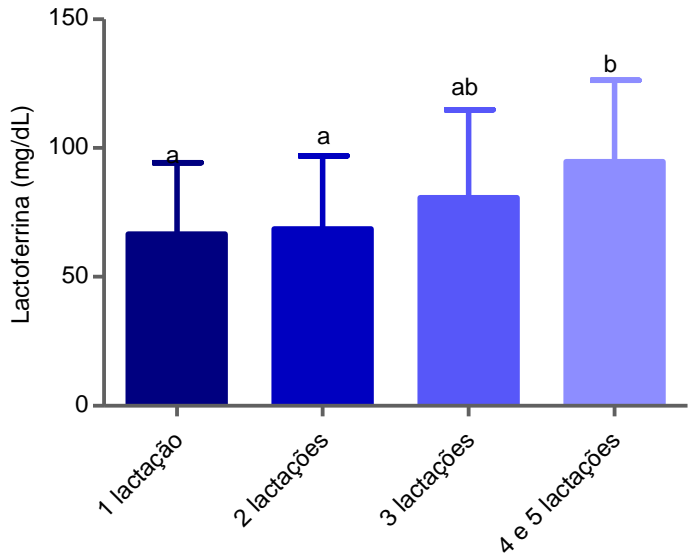

Número de lactações

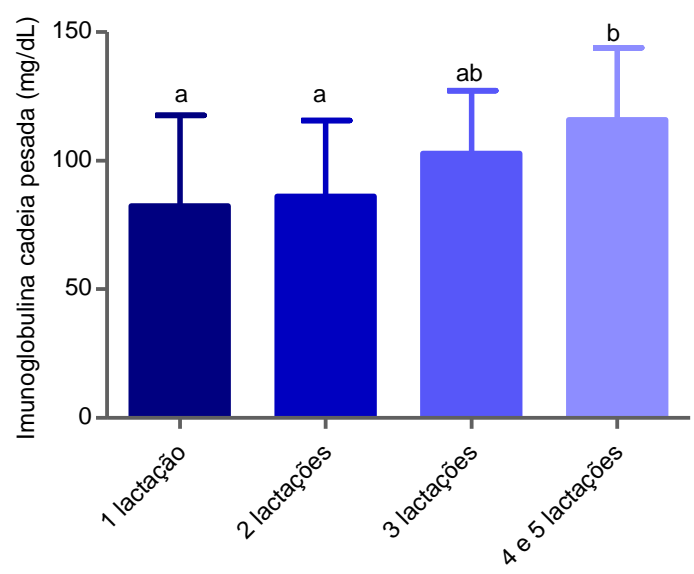

Número de lactações

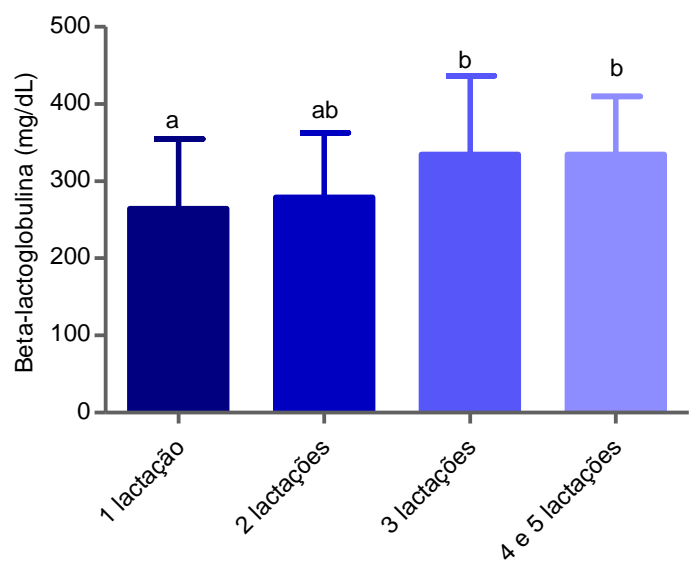

Número de lactações

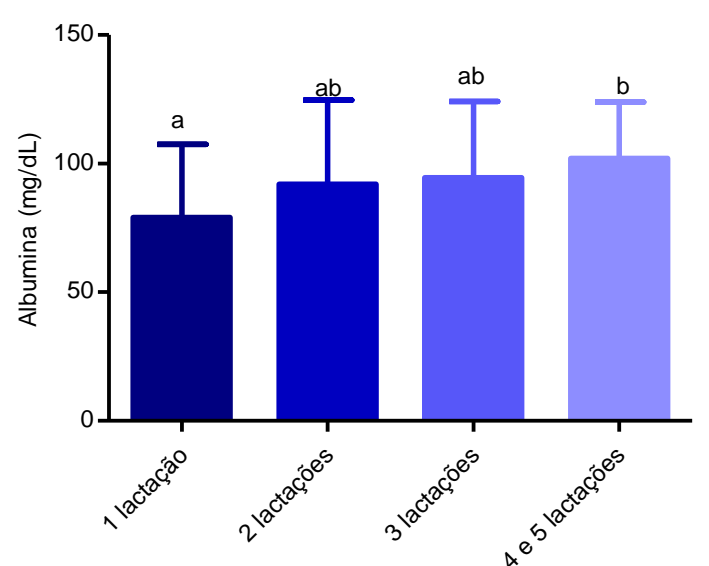

Número de lactações

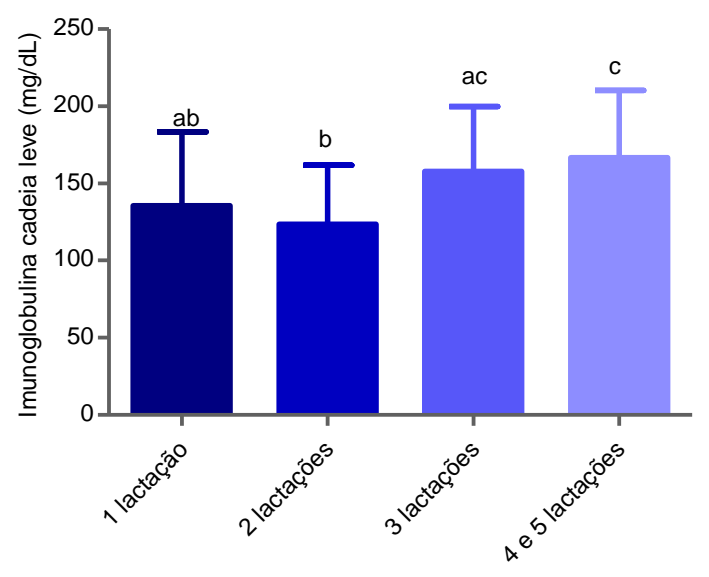

Número de lactações

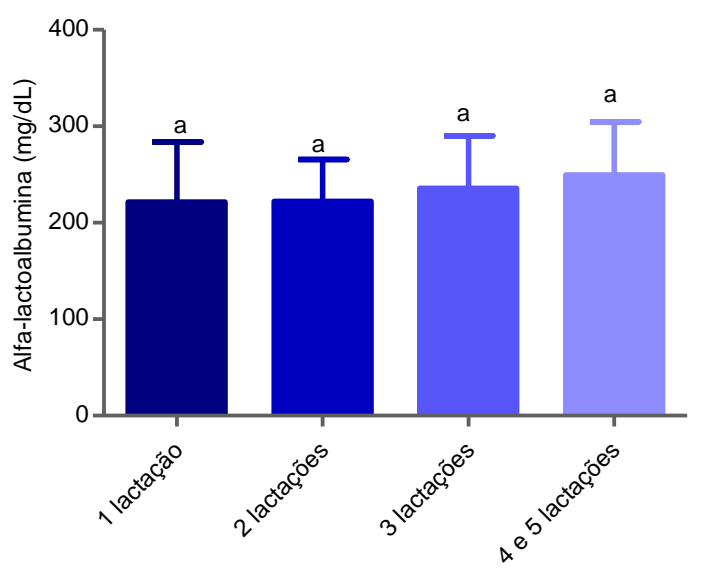

Número de lactações

Legenda: a,b,c - letras diferentes significam diferença estatística significante $(p \leq 0,05)$ - Teste de Bonferroni

Gráfico 17 - Avaliação da influência do número de lactações nas frações protéicas do soro lácteo do leite de cabras Saanen - São Paulo - 2007 a 2010. 
Tabela 7 - Média, desvio padrão (DP), intervalo de confiança (IC 95\%) da proteína total, proteína do soro de leite e das frações protéicas (lactoferrina; albumina; imunoglobulinas de cadeia pesada; imunoglobulinas de cadeia leve; $\beta$-lactoglobulina; $\alpha$-lactoalbumina) durante a de lactação de cabras Saanen - São Paulo - 2007 a 2010

\section{Proteinograma do leite de cabras durante a lactacão plena $(\mathrm{mg} / \mathrm{dL})$}

\begin{tabular}{|c|c|c|c|c|c|c|c|c|}
\hline Dias de lactação & $\begin{array}{c}\text { Proteína total } \\
\text { Média } \pm \text { DP } \\
\text { [IC 95\%] * }\end{array}$ & $\begin{array}{c}\text { Proteína do soro } \\
\text { Média } \pm \text { DP } \\
{\left[\text { IC 95\% }{ }^{*}\right.}\end{array}$ & $\begin{array}{c}\text { Lactoferrina } \\
\text { Média } \pm \text { DP } \\
{\left[\text { IC 95\% }{ }^{*}\right.}\end{array}$ & $\begin{array}{l}\text { Albumina } \\
\text { Média } \pm \text { DP } \\
{\left[\text { IC 95\% }{ }^{*}\right.}\end{array}$ & $\begin{array}{l}\text { lg Pesada } \\
\text { Média } \pm \text { DP } \\
{[\text { IC 95\%] * }}\end{array}$ & $\begin{array}{c}\text { lg leve } \\
\text { Média } \pm \text { DP } \\
\text { [IC 95\% }{ }^{*}\end{array}$ & $\begin{array}{c}\beta-L g \\
\text { Média } \pm \text { DP } \\
{\left[\text { IC 95\% }{ }^{*}\right.}\end{array}$ & $\begin{array}{c}\alpha-L a \\
\text { Média } \pm \text { DP } \\
{\left[\text { IC 95\% }{ }^{*}\right.}\end{array}$ \\
\hline $0 \nmid 15$ dias & $\begin{array}{c}3.524,0 \pm 610,0 \\
{[3.332,0-3.715,0]}\end{array}$ & $\begin{array}{c}1.136,0 \pm 305,6 \\
{[1.038,0-1.233,0]}\end{array}$ & $\begin{array}{c}88,5 \pm 33,5 \\
{[77,82-99,26]}\end{array}$ & $\begin{array}{c}110,4 \pm 39,0 \\
{[98,0-123,0]}\end{array}$ & $\begin{array}{c}141,0 \pm 45,0 \\
{[126,4-155,2]}\end{array}$ & $\begin{array}{c}161,0 \pm 67,5 \\
{[139,0-182,5]}\end{array}$ & $\begin{array}{c}352,7 \pm 86,5 \\
{[325,0-380,3]}\end{array}$ & $\begin{array}{c}218,3 \pm 50,0 \\
{[202,0-234,3]}\end{array}$ \\
\hline $15 \dashv 30$ dias & $\begin{array}{c}2.967,0 \pm 330,0 \\
{[2.865,0-3.069,0]}\end{array}$ & $\begin{array}{c}992,0 \pm 230,0 \\
{[918,0-1.066,0]}\end{array}$ & $\begin{array}{c}66,2 \pm 24,4 \\
{[58,4-74,0]}\end{array}$ & $\begin{array}{c}104,4 \pm 25,4 \\
{[96,0-112,6]}\end{array}$ & $\begin{array}{c}107,5 \pm 29,0 \\
{[98,0-117,0]}\end{array}$ & $\begin{array}{c}120,2 \pm 36,4 \\
{[108,6-132,0]}\end{array}$ & $\begin{array}{c}395,3 \pm 97,6 \\
{[364,0-426,5]}\end{array}$ & $\begin{array}{c}199,0 \pm 59,7 \\
{[179,7-218,0]}\end{array}$ \\
\hline $30-60$ dias & $\begin{array}{c}3.000 \pm 343,0 \\
{[2.897,0-3.110,0]}\end{array}$ & $\begin{array}{c}1.023,0 \pm 238,5 \\
{[946,2-1.099,0]}\end{array}$ & $\begin{array}{l}79,0 \pm 25,6 \\
{[70,7-87,0]}\end{array}$ & $\begin{array}{c}103,0 \pm 30,0 \\
{[93,0-112,6]}\end{array}$ & $\begin{array}{c}107,3 \pm 32,5 \\
{[97,0-117,7]}\end{array}$ & $\begin{array}{c}155,0 \pm 47,0 \\
{[140,0-170,0]}\end{array}$ & $\begin{array}{c}335,0 \pm 92,7 \\
{[305,3-364,6]}\end{array}$ & $\begin{array}{c}243,3 \pm 56,4 \\
{[225,3-261,3]}\end{array}$ \\
\hline $60 \dashv 120$ dias & $\begin{array}{c}2.815,0 \pm 179,0 \\
{[2.760,0-2.871,0]}\end{array}$ & $\begin{array}{c}889,0 \pm 175,5 \\
{[832,9-945,1]}\end{array}$ & $\begin{array}{c}72,0 \pm 26,5 \\
{[63,5-80,5]}\end{array}$ & $\begin{array}{c}85,0 \pm 22,0 \\
{[78,0-92,0]}\end{array}$ & $\begin{array}{c}91,5 \pm 26,0 \\
{[83,0-100,0]}\end{array}$ & $\begin{array}{c}136,5 \pm 36,4 \\
{[125,0-148,0]}\end{array}$ & $\begin{array}{c}274,0 \pm 58,6 \\
{[255,1-292,5]}\end{array}$ & $\begin{array}{c}230,3 \pm 38,0 \\
{[218,0-242,4]}\end{array}$ \\
\hline $120 \dashv 210$ dias & $\begin{array}{c}3.130,0 \pm 271,0 \\
{[3.046,0 \pm 3.214,0]}\end{array}$ & $\begin{array}{c}848,0 \pm 219,1 \\
{[778,0-918,0]}\end{array}$ & $\begin{array}{c}72,7 \pm 35,7 \\
{[61,3-84,0]}\end{array}$ & $\begin{array}{c}78,4 \pm 26,0 \\
{[70,0-87,0]}\end{array}$ & $\begin{array}{c}86,2 \pm 31,0 \\
{[76,4-96,0]}\end{array}$ & $\begin{array}{c}145,7 \pm 42,7 \\
{[132,0-159,5]}\end{array}$ & $\begin{array}{c}252,4 \pm 65,7 \\
{[231,3-273,4]}\end{array}$ & $\begin{array}{c}212,4 \pm 46,6 \\
{[197,5-227,3]}\end{array}$ \\
\hline
\end{tabular}

Legenda: $\left(^{*}\right)$ : intervalo de confiança, intervalo no qual estão compreendidos $95 \%$ dos valores da população Número de glândulas analisadas: 40 nos grupos de 1 a 5 e 37 amostras no grupo 6 (> 210 dias de lactação) 
Tabela 8- Média, desvio padrão (DP), intervalo de confiança (IC 95\%) da proteína total, proteína do soro de leite e das frações protéicas (lactoferrina; albumina; imunoglobulinas de cadeia pesada; imunoglobulinas de cadeia leve; $\beta$-lactoglobulina; $\alpha$-lactoalbumina) conforme o número de lactações de cabras Saanen - São Paulo - 2007 a 2010

\section{Proteinograma do leite de cabras de acordo com o número de lactações (mg/dL)}

\begin{tabular}{|c|c|c|c|c|c|c|c|c|}
\hline $\begin{array}{l}\text { Número de } \\
\text { Lactações }\end{array}$ & $\begin{array}{l}\text { Proteína total } \\
\text { Média } \pm \text { DP } \\
{[\text { IC 95\%] }}\end{array}$ & $\begin{array}{c}\text { Proteína do soro } \\
\text { Média } \pm \text { DP } \\
{[\text { IC 95\%] }}\end{array}$ & $\begin{array}{l}\text { Lactoferrina } \\
\text { Média } \pm \text { DP } \\
{[\text { IC 95\%] * }}\end{array}$ & $\begin{array}{l}\text { Albumina } \\
\text { Média } \pm \text { DP } \\
{[\text { IC 95\%] * }}\end{array}$ & $\begin{array}{l}\text { Ig Pesada } \\
\text { Média } \pm \text { DP } \\
{[\text { IC 95\%] * }}\end{array}$ & $\begin{array}{c}\text { Ig leve } \\
\text { Média } \pm \text { DP } \\
{[\text { IC 95\%] * }}\end{array}$ & $\begin{array}{c}\boldsymbol{\beta}-\mathbf{L g} \\
\text { Média } \pm \text { DP } \\
{[\text { IC 95\%] * }}\end{array}$ & $\begin{array}{c}\alpha-L a \\
\text { Média } \pm \text { DP } \\
{[\text { IC 95\%] * }}\end{array}$ \\
\hline 1 & $\begin{array}{l}3.110,0 \pm 320,0 \\
{[3.000-3.200]}\end{array}$ & $\begin{array}{c}849,3 \pm 268,4 \\
{[749,0-949,6]}\end{array}$ & $\begin{array}{c}66,7 \pm 27,5 \\
{[56,4-77,0]}\end{array}$ & $\begin{array}{c}79,0 \pm 28,4 \\
{[68,4-89,6]}\end{array}$ & $\begin{array}{c}82,4 \pm 35,0 \\
{[69,3-95,5]}\end{array}$ & $\begin{array}{c}135,5 \pm 48,0 \\
{[117,5-153,4]}\end{array}$ & $\begin{array}{c}264,3 \pm 90,7 \\
{[230,4-298,0]}\end{array}$ & $\begin{array}{c}221,4 \pm 62,4 \\
{[198,0-244,7]}\end{array}$ \\
\hline 2 & $\begin{array}{c}2.900 \pm 350,0 \\
{[2.780-3.000]}\end{array}$ & $\begin{array}{c}841,3 \pm 222,7 \\
{[788,2-954,5]}\end{array}$ & $\begin{array}{c}68,8 \pm 28,4 \\
{[58,0-79,2]}\end{array}$ & $\begin{array}{c}92,0 \pm 32,5 \\
{[80,0-104,3]}\end{array}$ & $\begin{array}{c}86,0 \pm 29,5 \\
{[75,0-97,0]}\end{array}$ & $\begin{array}{c}123,6 \pm 38,0 \\
{[109,4-137,8]}\end{array}$ & $\begin{array}{c}279,0 \pm 84,0 \\
{[247,5-310,0]}\end{array}$ & $\begin{array}{c}222,2 \pm 43,3 \\
{[206,0-238,4]}\end{array}$ \\
\hline 3 & $\begin{array}{l}3.000 \pm 327,67 \\
{[2.860-3.130]}\end{array}$ & $\begin{array}{c}1.006,0 \pm 227,5 \\
{[918,5-1.095,0]}\end{array}$ & $\begin{array}{c}80,7 \pm 34,0 \\
{[67,5-94,0]}\end{array}$ & $\begin{array}{c}94,5 \pm 29,6 \\
{[83,0-106,0]}\end{array}$ & $\begin{array}{c}103,0 \pm 24,3 \\
{[90,0-100,0]}\end{array}$ & $\begin{array}{c}158,0 \pm 42,0 \\
{[141,5-174,0]}\end{array}$ & $\begin{array}{c}334,0 \pm 102,0 \\
{[295,2-374,2]}\end{array}$ & $\begin{array}{c}235,8 \pm 54,4 \\
{[214,7-257,0]}\end{array}$ \\
\hline 4 e 5 & $\begin{array}{c}2.970 \pm 340,0 \\
{[2.850-3.100]}\end{array}$ & $\begin{array}{c}1.063,0 \pm 195,4 \\
{[990,4-1.136,0]}\end{array}$ & $\begin{array}{c}94,7 \pm 31,5 \\
{[83,0-106,0]}\end{array}$ & $\begin{array}{c}102,0 \pm 22,0 \\
{[94,0-110,0]}\end{array}$ & $\begin{array}{c}116,0 \pm 28,0 \\
{[105,3-126,3]}\end{array}$ & $\begin{array}{c}166,5 \pm 44,0 \\
{[150,0-183,0]}\end{array}$ & $\begin{array}{c}334,7 \pm 75,2 \\
{[306,0-363,0]}\end{array}$ & $\begin{array}{c}249,5 \pm 55,3 \\
{[229,0-270,2]}\end{array}$ \\
\hline
\end{tabular}

Legenda: (*): intervalo de confiança, intervalo no qual estão compreendidos $95 \%$ dos valores da população

Número de glândulas analisadas: 30 nos grupos de 1, 2 e 4 e 5 lactações e 24 amostras no grupo de cabras com 3 lactações 


\subsection{Influência do isolamento bacteriano no proteinograma do leite de cabras}

Pesquisas realizadas em vacas (URECH; PUHAN; SCHÄLLIBAUM, 1999; SANT'ANA, 2004; FORSBACK et al., 2010) e cabras (LEITNER; MERIN; SILANIKOVE, 2004) evidenciaram que os processos infecciosos da glândula mamária são responsáveis por alterações no proteinograma lácteo caracterizados por diminuição da síntese de proteínas como a caseína e transudação de proteína plasmática para o leite com consequente alteração nas diversas frações das proteínas do soro lácteo.
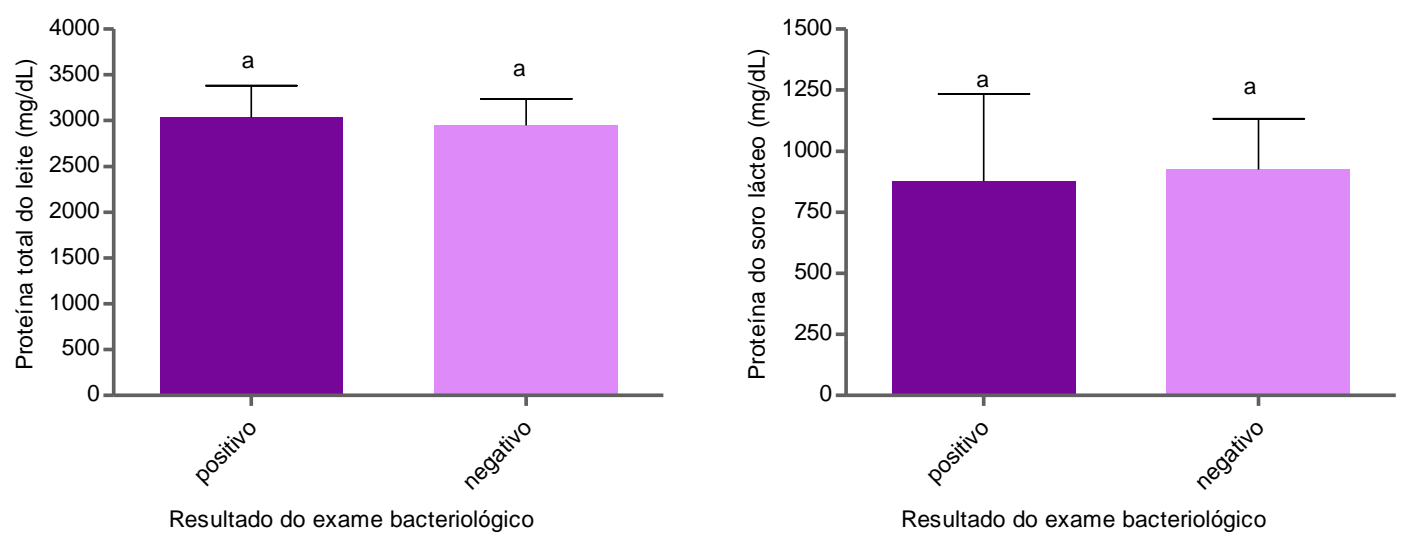

Legenda: letras diferentes significam diferença estatística significante $(p \leq 0,05)$ - ANOVA

Gráfico 18 - Avaliação da influência do isolamento bacteriano nos teores de proteína total do leite e proteína do soro lácteo de cabras Saanen - São Paulo 2007 a 2010

Ao analisar os resultados obtidos (Tabela 10 e Gráfico 18) verificou-se não haver influência do isolamento bacteriano nas concentrações de proteína total do leite de cabras que foram iguais a $3.030 \pm 350,0$ em amostras com isolamento bacteriano e iguais a $2.950 \pm 290,0$ nas amostras do grupo controle negativo. Da mesma forma não houve alterações na concentração de proteína do soro lácteo em amostras de leite positivas no exame microbiológico $(877,7 \pm 356,4 \mathrm{mg} / \mathrm{dL})$ quando comparadas com amostras negativas no exame microbiológico (926,0 $\pm 207,0$ $\mathrm{mg} / \mathrm{dL}$ ). Esses fatos mostram que nas condições em que o experimento foi realizado não ocorreu passagem de plasma sangüíneo para o leite, ou seja, não existia alteração evidente da glândula mamária que permitisse afirmar a existência de mamite. 
No processo de seleção das glândulas mamárias, seguiu-se as recomendações de Birgel (2004), de tal forma que foram utilizadas somente mamas que não apresentaram alterações nas características macroscópicas do leite (detectadas na prova do fundo escuro) ou na consistência (detectadas por palpação após a ordenha) que pudessem ser relacionadas a existência de processo inflamatório. Afora isso as amostras colhidas foram submetidas à análise físicoquímica ( $\mathrm{pH}$, eletrocondutividade, lactose, gordura e sólidos totais), sendo que as amostras utilizadas não apresentavam alterações nessas características.

Os gêneros e espécies de bactérias isoladas na presente pesquisa estão de acordo com estudos anteriores que observaram que dentre os agentes etiológicos bacterianos identificados na mastite caprina, a maioria é similar aos encontrados na espécie bovina (CONTRERAS et al., 2003; LANGONI; DOMINGUES; BALDINI, 2006; SCHMIDT et al., 2009; NEVES et al., 2010). Foram utilizadas 44 amostras de leite de cabras positivas no exame microbiológico, das quais foram isoladas e identificadas 29 amostras do gênero Staphylococcus, 06 amostras do gênero Streptococcus provenientes de 5 cabras e 09 amostras do gênero Corynebacterium. As bactérias isoladas do gênero Staphylococcus foram classificadas em 10 espécies diferentes descritas na Tabela a seguir (Tabela 9).

Tabela 9 - Descrição do gênero e da espécie de bactérias isoladas no leite de cabras - São Paulo - 2007 a 2010

\begin{tabular}{llc}
\hline $\begin{array}{c}\text { Gênero da bactéria } \\
\text { isolada }\end{array}$ & Espécie identificada & $\begin{array}{c}\text { Número de } \\
\text { amostras }\end{array}$ \\
\hline & Staphylococcus aureus & 02 \\
& Staphylococcus caseolyticus & 01 \\
& Staphylococcus chromogenes & 01 \\
& Staphylococcus epidermidis & 05 \\
Staphylococcus & Staphylococcus Hominis & 10 \\
& Staphylococcus kloosii & 01 \\
& Staphylococcus lugdunensis & 06 \\
& Staphylococcus pasteuri & 01 \\
& Staphylococcus sciuri & 01 \\
& Staphylococcus sp & 01 \\
\hline Total Staphylococcus & & 29 \\
\hline Streptococcus & Streptococcus sp & 06 \\
\hline Corynebacterium & Corynebacterium sp & 09 \\
\hline TOTAL & & 44 \\
\hline
\end{tabular}


Em contraste, com ausência de alteração da proteína do soro lácteo em relação ao resultado do exame microbiológico, no fracionamento das proteínas foi observado aumento nos teores de lactoferrina e diminuição nos teores das principais proteínas do soro de leite $\beta$-Lg e $\alpha$-La.

As concentrações de lactoferrina obtidas nas amostras com isolamento bacteriano foram iguais a $92,7 \pm 46,0 \mathrm{mg} / \mathrm{dL}$ enquanto que nas amostras negativas no exame microbiológico foram iguais a 72,0 $\pm 23,0 \mathrm{mg} / \mathrm{dL}$ (Tabela 10 e Gráfico 19). Esses resultados estão de acordo com os obtidos em estudos anteriores que também descreveram um aumento dos teores de lactoferrina em amostras com isolamento bacteriano, assim como em amostras de leite com mamite (CHEN; CHEN; MAO, 2004; KAWAl et al., 2007; CHANETON et al., 2008; HYVÖNEN et al., 2009; BARTH et al., 2010; FORSBACK et al., 2010).

A lactoferrina é uma proteína que atua na imunidade da glândula mamária, diante de infecções e inflamações atua como a primeira linha de proteção com ação bacteriostática, pela capacidade de seqüestrar o ferro livre e atividade antibacteriana pela habilidade em se ligar a membrana exterior de bactérias Gram-negativas causando liberação rápida de lipopolisacárides e aumento na permeabilidade da membrana, além disso, durante a inflamação é liberada de grânulos secundários de neutrófilos refletindo o aumento da CCS (FARRELL et al., 2004).

Os resultados da presente pesquisa (Tabela 10 e figura 19) demonstraram que apesar das glândulas mamárias não apresentarem alterações nas características macroscópicas do leite, na palpação do parênquima e nas características físico-químicas, a lactoferrina pode ser um indicativo precoce de resposta da glândula mamária frente a infecção bacteriana, principalmente em cabras devido às limitações da contagem de células somáticas (CCS) como indicador de infecção intramamária como foi referido por Barth et al. (2010).

As concetrações de $\alpha$ - $\mathrm{La}(179,2 \pm 54,0 \mathrm{mg} / \mathrm{dL})$ e $\beta$ - $\mathrm{Lg}(252,5 \pm 110,2 \mathrm{mg} / \mathrm{dL})$ (Tabela 10 e figura 19) nas amostras de leite com isolamento bacteriano foram menores quando comparadas com as concentrações obtidas em amostras negativas no exame microbiológico ( $\alpha$-La igual a $226,3 \pm 44,0$ e $\beta$-Lg igual a 297,3 \pm 81,2 $\mathrm{mg} / \mathrm{dL}$ ) essas observações concordam parcialmente com os resultados obtidos por Caffin, Poutrel e Rainard (1985) e Sant'Ana (2004) que observaram diminuição nos teores de $\alpha$-La no leite de vacas com isolamento bacteriano, enquanto que as concentrações de $\beta$ - Lg não foram influenciadas pelo isolamento bacteriano. A fração 
a-La é precusrora da síntese de lactose, a diminuição dessa fração pode estar associada às diminuições nos teores de lactose que ocorrem no leite mamitoso, contudo, na presente pesquisa não ocorreu essa diminuição. Caffin, Poutrel e Rainard (1985) descreveram que a menor concentração de $\alpha$-La em vacas com infecção mamária coincidiu com a diminuição dos teores de lactose.

As demais frações do soro lácteo (Tabela 10 e Gráfico 19), imunoglobulina de cadeia pesada e de cadeia leve, assim como as concentrações de albumina sérica não foram influenciadas pelo isolamento bacteriano discordando de Caffin, Poutrel e Rainard (1983) e Caffin e Poutrel (1988) que observaram aumento nas concentrações de $\operatorname{lgG}_{1}$ e $\lg G_{2}$, respectivamente, em quartos mamários de vacas com isolamento de Corynebacterium bovis, e Staphylococcus aureus.

Tabela 10 - Média, desvio padrão (DP), intervalo de confiança (IC 95\%) da proteína total, proteína do soro lácteo e das frações protéicas (lactoferrina; albumina; imunoglobulinas de cadeia pesada, imunoglobulina cadeia leve, $\beta$ lactoglobulina e a-lactoalbumina) no leite de cabras Saanen positivas no exame bacteriológico e no leite de cabras negativas no exame bacteriológico - São Paulo - 2007 a 2010

\begin{tabular}{|c|c|c|}
\hline \multirow[b]{2}{*}{ Proteinograma } & \multicolumn{2}{|c|}{ RESULTADO DO EXAME BACTERIOLÓGICO } \\
\hline & $\begin{array}{c}\text { Positivo } \\
\text { Média } \pm \text { DP }(\mathrm{mg} / \mathrm{dL}) \\
{[\mathrm{IC} 95 \%]}\end{array}$ & $\begin{array}{c}\text { Controle negativo } \\
\text { Média } \pm \text { DP }(\mathrm{mg} / \mathrm{dL}) \\
{[\mathrm{IC} 95 \%]}\end{array}$ \\
\hline Proteína total & $\begin{array}{c}3.030 \pm 350,0 \\
{[2.900-3.100]}\end{array}$ & $\begin{array}{c}2.950 \pm 290,0 \\
{[2.900-3.000]}\end{array}$ \\
\hline Proteína do soro & $\begin{array}{c}877,7 \pm 356,4 \\
{[769,0-986,0]}\end{array}$ & $\begin{array}{c}926,0 \pm 207,0 \\
{[863,0-989,0]}\end{array}$ \\
\hline Lactoferrina & $\begin{array}{c}92,7 \pm 46,0 \\
{[78,0-106,0]}\end{array}$ & $\begin{array}{c}72,2 \pm 23,0 \\
{[63,0-80,0]}\end{array}$ \\
\hline Albumina & $\begin{array}{c}88,3 \pm 44,0 \\
{[75,0-101,0]}\end{array}$ & $\begin{array}{c}91,2 \pm 23,5 \\
{[84,0-98,0]}\end{array}$ \\
\hline Ig pesada & $\begin{array}{c}94,0 \pm 43,0 \\
{[81,0-107,3]}\end{array}$ & $\begin{array}{c}93,3 \pm 28,5 \\
{[84,0-102,0]}\end{array}$ \\
\hline Ig leve & $\begin{array}{c}137,0 \pm 65,6 \\
{[116,0-156,0]}\end{array}$ & $\begin{array}{c}145,7 \pm 42,0 \\
{[133,0-158,0]}\end{array}$ \\
\hline$\beta-\operatorname{Lg}$ & $\begin{array}{c}252,5 \pm 110,2 \\
{[219,0-286,0]}\end{array}$ & $\begin{array}{c}297,3 \pm 81,2 \\
{[272,0-322,0]}\end{array}$ \\
\hline$\alpha$-La & $\begin{array}{c}179,2 \pm 54,0 \\
{[163,0-195,0]}\end{array}$ & $\begin{array}{c}226,3 \pm 44,0 \\
{[213,0-239,0]}\end{array}$ \\
\hline
\end{tabular}




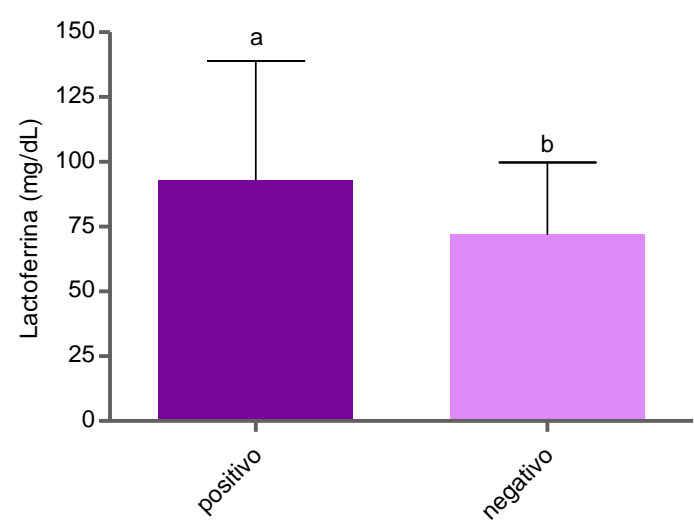

Resultado do exame bacteriológico

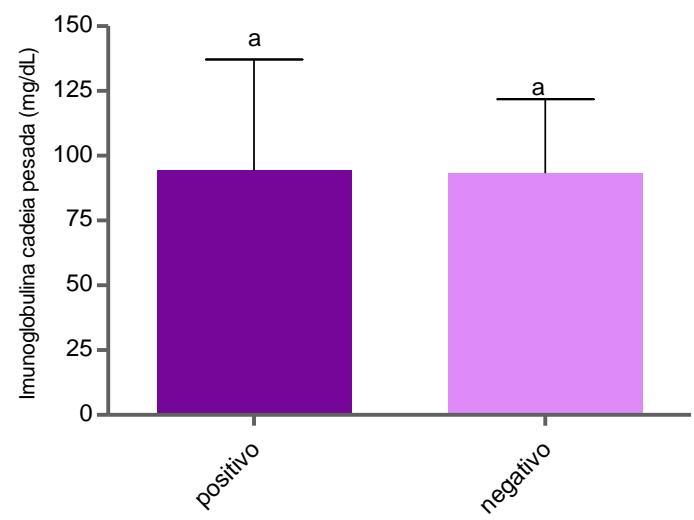

Resultado do exame bacteriológico

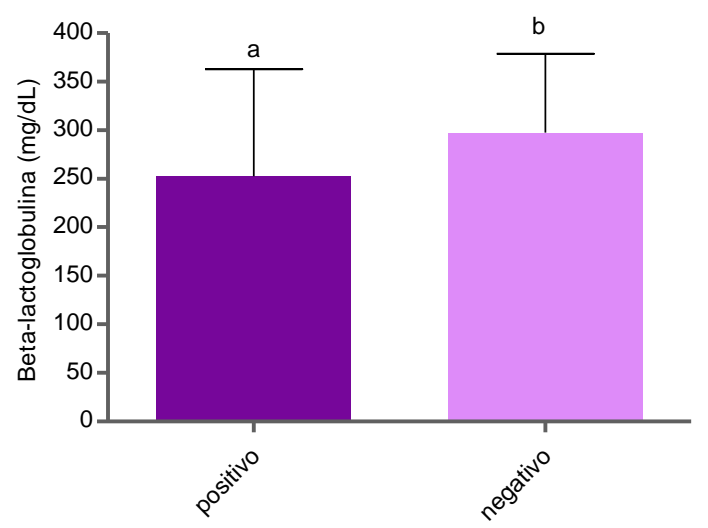

Resultado do exame bacteriológico

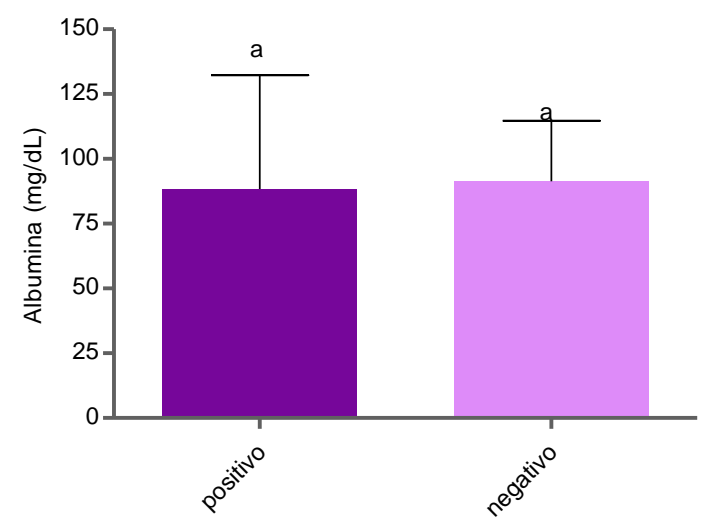

Resultado do exame bacteriológico

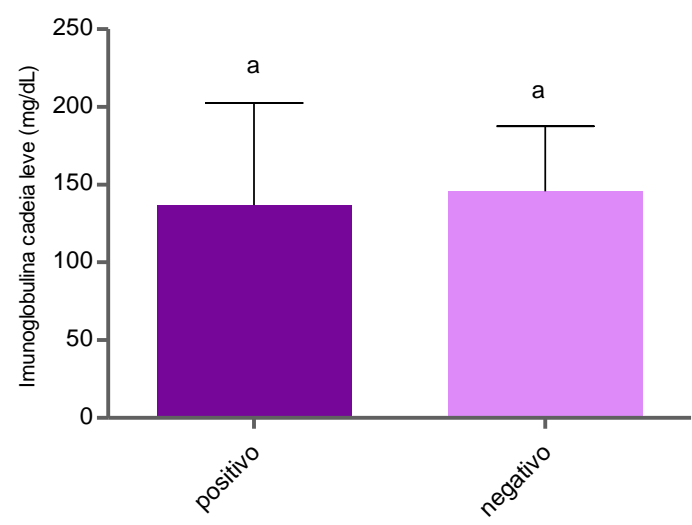

Resultado do exame bacteriológico

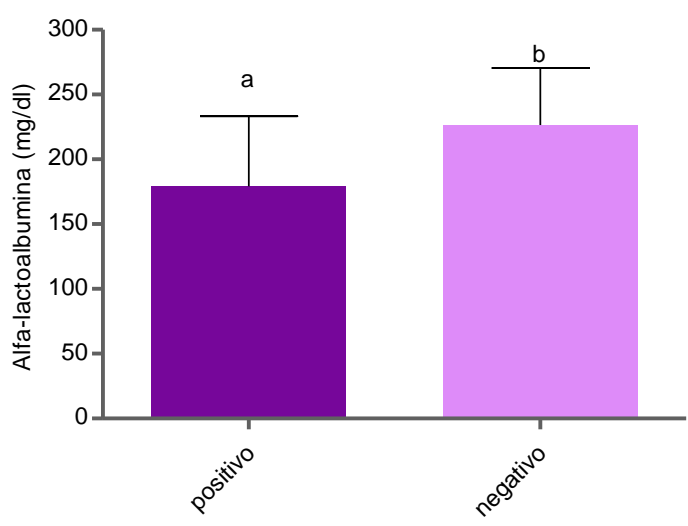

Resultado do exame bacteriológico

Legenda: $a, b$ - letras diferentes significam diferença estatística significante $(p \leq 0,05)$ - ANOVA

Gráfico 19 - Avaliação da influência do isolamento bacteriano nas frações protéicas do soro lácteo do leite de cabras Saanen - São Paulo - 2007 a 2010. 


\subsection{Influência do vírus da artrite e encefalite caprina no proteinograma do leite de cabras}

Os resultados do presente estudo demonstraram que não houve influência da infecção pelo CAEV nas concentrações de proteína total (Tabela 11 e Gráfico 20), pois os teores obtidos em amostras de cabras positivas para o vírus da CAE (2.910 $\pm 260,0 \mathrm{mg} / \mathrm{dL}$ ) foram semelhantes aos teores obtidos em cabras negativas do grupo controle $(2.910 \pm 270,0 \mathrm{mg} / \mathrm{dL})$. Essas observações estão de acordo com os resultados obtidos Birgel Junior et al. (2005), que também não verificaram diferenças nos teores de proteína total no leite de cabras positivas e negativas para o vírus da CAE. As concentrações de proteína do soro de leite (Tabela 11 e Gráfico 20) também não foram influenciadas pela presença do vírus da CAE quando comparadas cabras positivas para com cabras negativas do grupo controle.
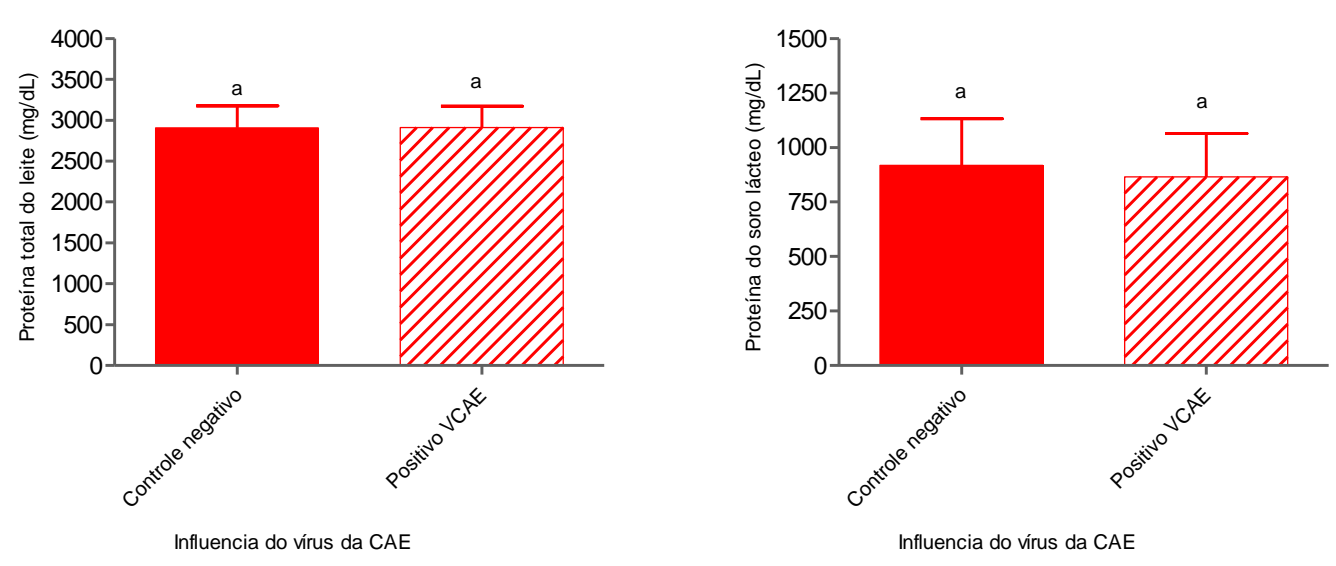

Legenda: letras diferentes significam diferença estatística significante $(p \leq 0,05)$ - ANOVA

Gráfico 20 - Avaliação da influência do vírus da Artrite e encefalite caprina (CAE) nos teores de proteína total do leite e proteína do soro lácteo de cabras Saanen - São Paulo - 2007 a 2010.

Em contraste, com os resultados da concentração de proteína do soro lácteo que não variou, os resultados obtidos no fracionamento das proteínas do soro de leite demonstraram existir influência do CAEV, pois, ocorreu diminuição na concentração de lactoferrina e $\alpha$-La, (Tabela 11 e Gráficos 21 e 22).

As concentrações de $\alpha$-La, segunda principal proteína do soro lácteo, foram menores em cabras sororeagente positivas para o CAEV $(192,6 \pm 46,6 \mathrm{mg} / \mathrm{dL})$ quando comparadas com as concentrações obtidas no grupo controle $(227,2 \pm 47,2$ 
$\mathrm{mg} / \mathrm{dL}$ ). A $\alpha$-La é essencial na síntese de lactose, pois juntamente com $\beta 1,4$ galactosiltransferase formam o complexo lactose-sintetase no aparelho de Golgi do epitélio mamário (FARRELL et al., 2004; BLECK et al., 2009). Bleck et al. (2009) correlacionaram a concentração de $\alpha$-La com a concentração de lactose no leite e Birgel Junior et al. (2007) e Almeida (2009) constataram diminuição dos teores de lactose no leite de cabras positivas para o CAEV. Na presente pesquisa demonstrou-se que cabras positivas para o CAEV apresentaram, em termos percentuais, $3 \%$ menos de $\alpha$-La em relação aos animais negativos para o CAEV (Gráfico 21).

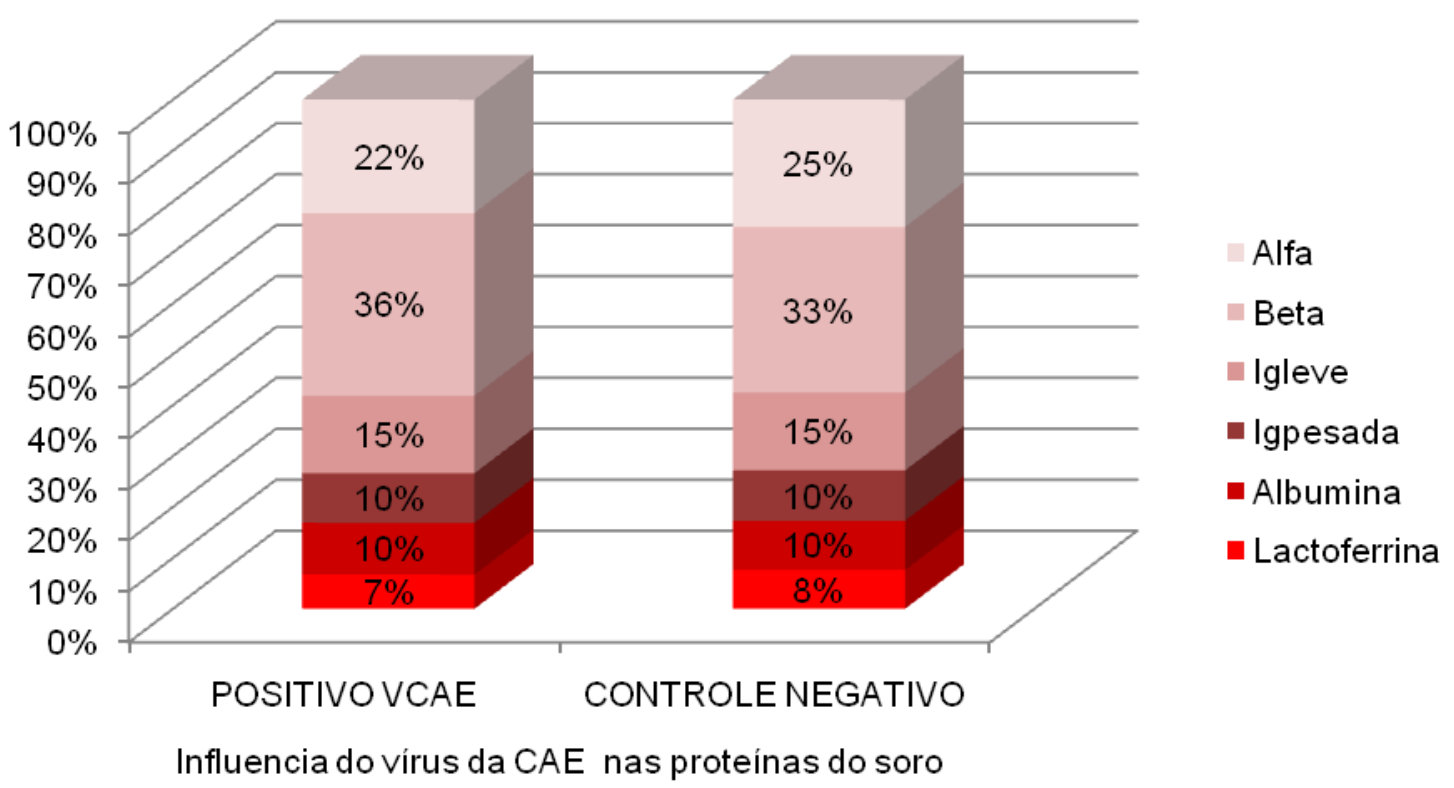

Gráfico 21 - Concentração (\%) das proteínas fracionadas em relação à proteína do soro no leite de cabras da raça Saanen sororeagentes positivas ao antígeno do vírus da Artrite e encefalite caprina e cabras controle negativo ao antígeno do vírus da Artrite e encefalite caprina obtida através da técnica de eletroforese em gel de poliacrilamida (12\%) (SDS-PAGE) - São Paulo 2007 a 2010.

Os resultados obtidos na presente pesquisa podem explicar achados que correlacionaram a infecção pelo CAEV com a diminuição da produção leiteira de cabras (BOHLAND; D'ANGELINO, 2005). Em condições brasileiras de criação, esses autores constataram que a produção leiteira nas cabras infectadas pelo CAEV foi $21,5 \%$ menor do que nos animais não infectados e que cabras infectadas apresentavam lactações mais curtas, sendo a sua duração, em média, 37 dias menor do que a observada em animais não infectados. O complexo enzima lactosesintetase é responsável pela regulação osmótica do volume de leite.(BREW, 2003; 
ZHANG; BREW, 2003), pois a lactose formada se acumula no complexo de Golgi ocasionando a entrada de água neste aparato, promovendo a formação da fase aquosa do leite.

No leite com mamite as concentrações de lactoferrina multiplicam devido às grandes quantias de leucócitos ativados liberados, dessa maneira ela desempenha um papel protetor na glândula mamária (KORHONEN; MARNILA, 2003). Diante de infecções e inflamações a lactoferrina atua como a primeira linha de proteção com ação bacteriostática, pela capacidade de seqüestrar o ferro livre que é um essencial nutriente para a bactéria, e também atividade antibacteriana pela habilidade em se ligar a membrana exterior de bactérias Gram-negativas causando a liberação rápida de lipopolisacárides e um aumento na permeabilidade da membrana (FARRELL et al., 2004). Os resultados obtidos na presente pesquisa mostram que as concentrações de lactoferrina foram menores $(p>0,05)$ em cabras sororeagentes positivas aos antígenos do CAEV (61,3 $\pm 18,0 \mathrm{mg} / \mathrm{dL})$ quando comparadas com amostras do grupo controle negativo $(72,3 \pm 26,0 \mathrm{mg} / \mathrm{dL})$. Esse fato é indicativo que a infecção pelo CAEV determina diminuição da capacidade de resposta orgânica as infecções bacterianas. O mecanismo que determinaria esse fenômeno não pode ser esclarecido, porém é sabido que a lactoferrina desempenha atividade antiviral contra vírus RNA e DNA (FARRELL et al., 2004).

Smith e Cutlip (1988) demonstraram em cabras infectadas pelo CAEV a existência de predisposição às infecções bacterianas na glândula mamária. Essa predisposição seria mais um indicativo dos efeitos imunossupressores da infecção causada por este vírus. De acordo com Birgel Junior a freqüência de glândulas mamárias com isolamento bacteriano é maior nos animais infectados pelo CAEV $(30,62 \%$ - 49/160) quando comparados com o número de mamas com isolamento bacteriano nos animais negativos ao CAEV (18,51\% - 52/281) (em fase de elaboração $)^{2}$. Esses fatos mostram que a infecção pelo CAEV é fator predisponente para instalação de processos infecciosos na glândula mamária. Fenômeno, também, descrito para os processos articulares que envolvem o CAEV, segundo Ramalho (2000) a infecção pelo CAEV seria um fator predisponente à instalação do Mycoplasma spp nas articulações, agravando os casos clínicos de artrites. A referida autora observou significativa associação entre a infecção pelo vírus da CAE e por

\footnotetext{
${ }^{2}$ Birgel Junior, E. H. Influência da infecção pelo Vírus da artrite-encefalite caprina no isolamento bacteriano no leite de cabras. A ser publicado, 2010.
} 
Mycoplasma spp, sendo a significativa maioria dos caprinos com Micoplasmose sororeagentes positiva para o vírus da CAE $(93,3 \%$ - 14/15).

Afora a Lactoferrina $(84,0 \pm 4,0 \mathrm{kDa})$ e a $\alpha$-La $(12,0 \pm 0,65 \mathrm{kDa})$. foram identificadas e quantificadas as seguintes frações protéicas no leite de cabras da raça Saanen positivas e negativas para os antígenos do vírus da $C A E$,: Albumina sérica (66,0 \pm 2,0 kDa); Imunoglobulina de Cadeia Pesada $(52,0 \pm 2,0 \mathrm{kDa})$; Imunoglobulina de Cadeia Leve (26,0 \pm 1,5 kDa) e $\beta$ - Lg (16,0 \pm 1,0 kDa). Conforme pode ser observado essas frações não sofreram alterações que pudessem estar relacionados com a infecção pelo CAEV (Gráfico 22 e Tabela 11). 

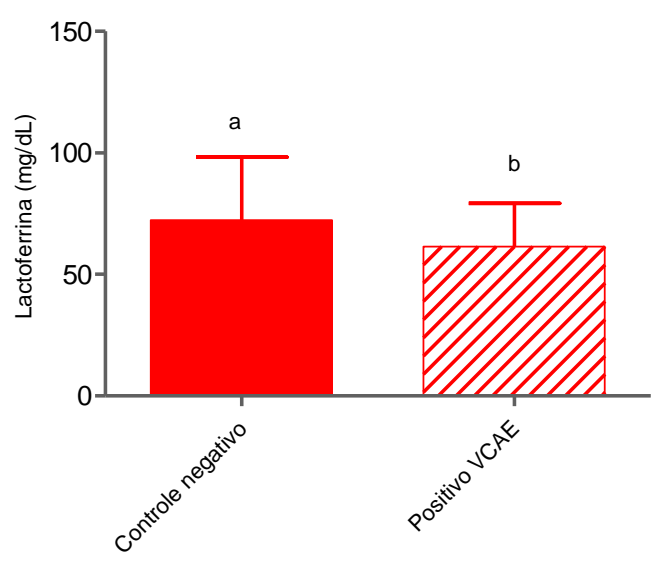

Influencia do vírus da CAE
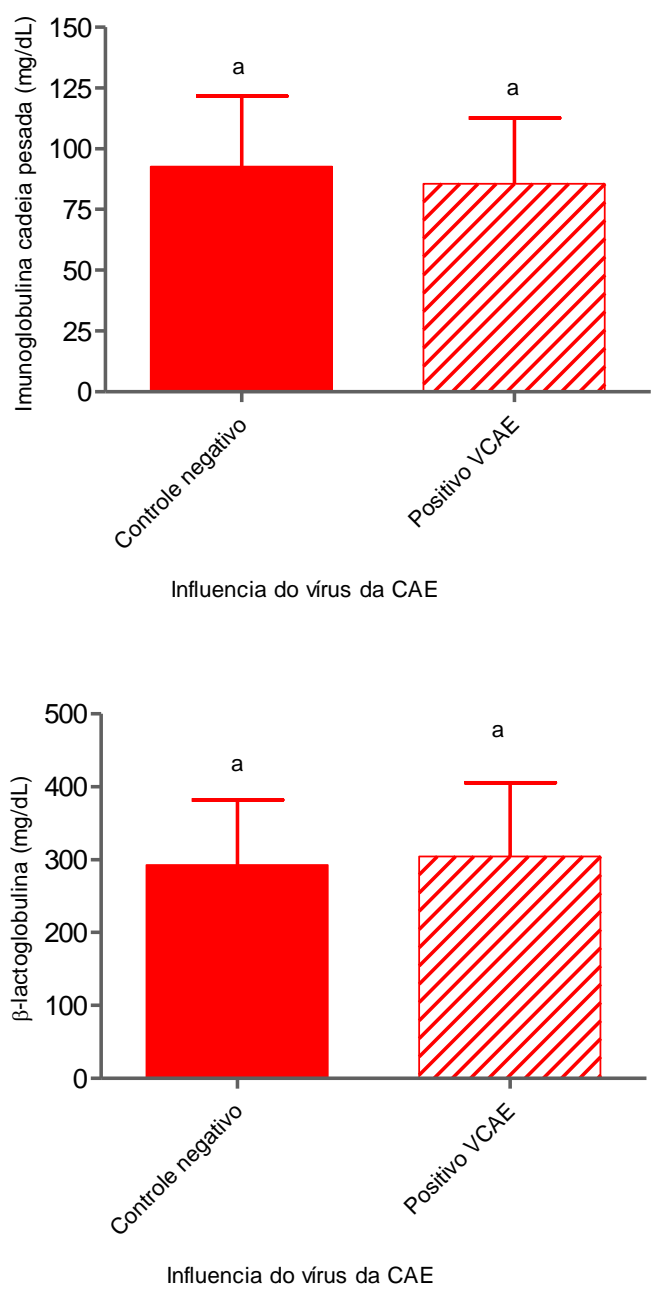
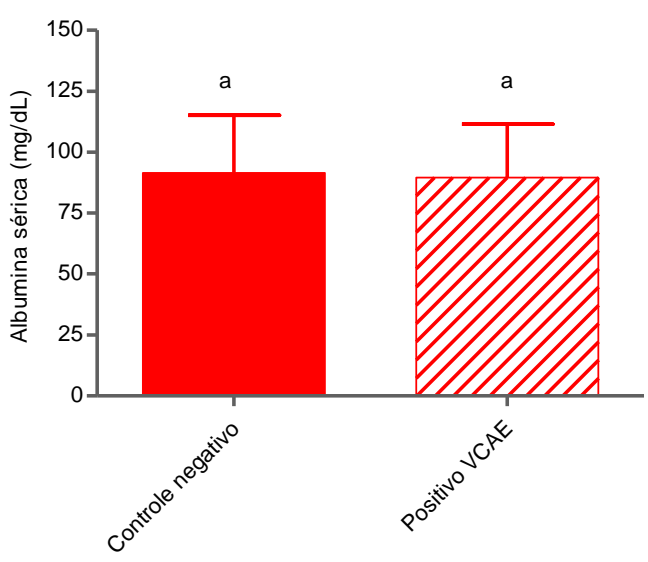

Influencia do vírus da CAE
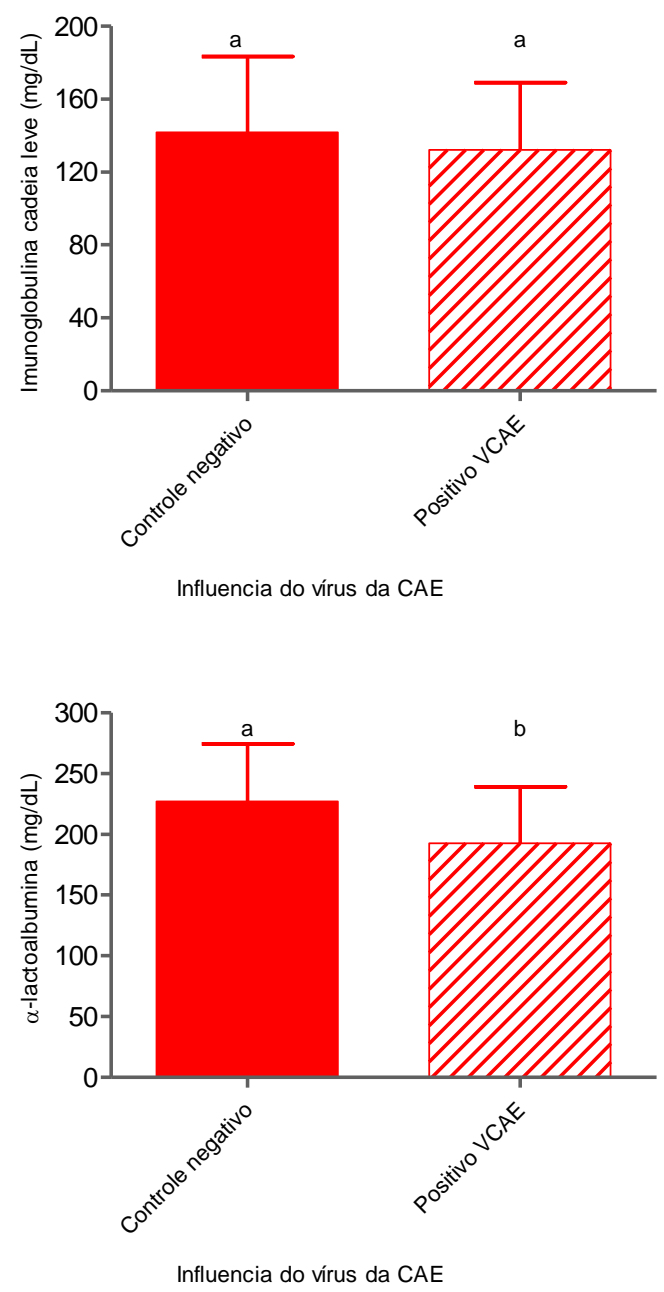

Letras diferentes significam diferença estatística significante $(p \leq 0,05)$ - ANOVA

Gráfico 22 - Avaliação da influência do vírus da artrite e encefalite caprina (CAE) nas frações protéicas do soro lácteo do leite de cabras Saanen - São Paulo - 2007 a 2010. 
Tabela 11 - Média, desvio padrão (DP) e intervalo de confiança (95\%) da proteína total, proteína do soro e das frações protéicas (lactoferrina; albumina; imunoglobulinas de cadeia pesada; imunoglobulinas de cadeia leve; $\beta$-lactoglobulina; $\alpha$-lactoalbumina) no leite de cabras Saanen sororeagentes positivas ao antígeno do vírus da Artrite e encefalite caprina e cabras controle negativo - São Paulo - 2007 a 2010.

\begin{tabular}{c|c|c|}
\hline \multicolumn{2}{|c|}{ Influência do vírus CAE no proteinograma do leite de cabra } \\
\hline \multirow{2}{*}{ PROTEínAS } & $\begin{array}{c}\text { CONTROLE NEGATIVO } \\
\text { Média } \pm \text { DP } \\
{[\text { IC 95\%] }}\end{array}$ & $\begin{array}{c}\text { POSITIVO CAEV } \\
\text { Média } \pm \text { DP } \\
{[\text { IC 95\%] }}\end{array}$ \\
\hline \multirow{2}{*}{ Proteína total } & $2.910 \pm 270,0$ & $2.910 \pm 260,0$ \\
& {$[2.800-3.000]$} & {$[2.800-3.000]$} \\
\hline \multirow{2}{*}{ Proteína do soro } & $918,0 \pm 215,3$ & $865,3 \pm 199,3$ \\
& {$[857,0-979,0]$} & {$[808,9-922,3]$} \\
\hline \multirow{2}{*}{ Lactoferrina } & $72,3 \pm 26,0$ & $61,3 \pm 18,0$ \\
& {$[64,9-79,6]$} & {$[56,2-66,4]$} \\
\hline \multirow{2}{*}{ Albumina } & $91,5 \pm 23,5$ & $89,6 \pm 21,7$ \\
& {$[84,4-98,28]$} & {$[83,5-95,8]$} \\
\hline \multirow{2}{*}{ Ig pesada } & $92,6 \pm 29,0$ & $85,5 \pm 27,1$ \\
& {$[84,3-100,9]$} & {$[77,8-93,2]$} \\
\hline \multirow{2}{*}{ Ig Leve } & $141,7 \pm 41,7$ & $132,2 \pm 36,8$ \\
& {$[129,8-153,6]$} & {$[121,7-142,7]$} \\
\hline \multirow{2}{*}{ B-Lg } & $292,7 \pm 89,27$ & $304,2 \pm 101,4$ \\
& {$[267,3-318,0]$} & {$[275,4-333,0]$} \\
\hline \multirow{2}{*}{ a- La } & $227,2 \pm 47,2$ & $192,6 \pm 46,6$ \\
& {$[213,8-240,7]$} & $5179,4-205,8]$ \\
\hline Total de amostras & $\mathbf{5 0}$ & $\mathbf{5 0}$ \\
\hline
\end{tabular}


Conclusōes

$z^{z=}=z_{z=} z_{z=z_{z x}}$ 


\section{CONCLUSÕES}

ESTUDO 1 - A análise dos resultados da avaliação da influência do processo de secagem da glândula mamária no proteinograma da secreção láctea de cabras permitiu as seguintes conclusões:

a. Ocorre um aumento progressivo nos valores absolutos de proteína total causado pelo aumento dos valores absolutos da proteína do soro lácteo, sendo observado aumento progressivo nos valores absolutos de todas as frações protéicas avaliadas (lactoferrina; albumina; imunoglobulinas de cadeia pesada; imunoglobulinas de cadeia leve; $\beta$-Lg e $\alpha$-La);

b. Antes da secagem predominavam as frações de $\beta$-Lg e $\alpha$-La, a partir do $3^{\circ}$ dia observa-se surgimento de novas frações e alteração do perfil protéico sem o predomínio de nenhuma fração;

c. A partir do $3^{\circ}$ dia de secagem houve o aparecimento de novas frações protéicas (proteína com peso molecular entre 30 e 44 kDa; proteína com peso molecular entre 100 e 297 kDa; proteína peso molecular médio de 11,0 0 0,69 KDa e proteína com peso molecular médio de 67,0 \pm 1,0 KDa);

ESTUDO 2 - A análise dos resultados da avaliação da influência do período colostral e do primeiro mês de lactação no proteinograma da secreção láctea de cabras permitiu as seguintes conclusões:

a. As altas concentrações de proteína total durante as primeiras 24 horas de lactação são quase iguais a alta concentração de proteína do soro demonstrando mínima secreção de caseína nesse período;

b. As concentrações de todas as frações protéicas obtidas (lactoferrina; albumina; imunoglobulinas de cadeia pesada; imunoglobulinas de cadeia leve; $\beta$-Lg e $\alpha$-La) foram máximas nas primeiras 12 horas de lactação;

c. Na primeira semana de lactação ocorre inversão no predomínio protéico na secreção, nas primeiras 24 horas predomina as imunoglobulinas, enquanto que, a partir do $5^{\circ}$ dia o predomínio passa a ser das frações $\alpha$-La e $\beta$-Lg; 
d. Nas primeiras 24 horas de lactação foram observadas novas frações protéicas com peso molecular entre 132 e $244 \mathrm{kDa}$ e nos primeiros 15 dias de lactação fração com peso molecular entre 30 e $50 \mathrm{kDa}$;

ESTUDO 3 - A análise dos resultados do proteinograma do leite de cabras durante a lactação plena: valores de referência, influência da fase de lactação e do número de lactações, permitiu as seguintes conclusões:

a. Valores de referência para lactação plena baseados nos intervalos de confiança obtidos: proteína total entre $2.940,0$ e $3.050 \mathrm{mg} / \mathrm{dL}$; proteína do soro lácteo entre 903,0 e 973,0 mg/dL; lactoferrina entre 68,0 e 77,0 mg/dL; albumina entre 88,0 e 97,0 mg/dL; imunoglobulina cadeia pesada entre 93,3 e $103,0 \mathrm{mg} / \mathrm{dL}$; imunoglobulina cadeia leve entre 132,7 e $146,0 \mathrm{mg} / \mathrm{dL} ; \beta$ lactoglobulina entre 299,0 e $329,0 \mathrm{mg} / \mathrm{dL}$ e $\alpha$-lactoalbumina entre 213,0 e 229,5;

b. O soro lácteo de cabras durante a lactação plena é composto principalmente pelas proteínas $\alpha$-La e $\beta-\mathrm{Lg}$, percentualmente foram iguais a $\beta-\mathrm{Lg}(33 \%)$ e $\alpha$ La (24\%) que juntas corresponderam a $57 \%$ de todas as proteínas do soro lácteo;

c. As concentrações de proteína total, da proteína do soro lácteo e das frações protéicas sofrem influência da fase de lactação, sendo:

- A concentração da proteína total, proteína do soro lácteo e das frações protéicas são maiores nos primeiros 15 dias de lactação devido à fase colostral;

- As concentrações de lactoferrina e imunoglobulinas de cadeia pesada são estáveis após os 15 dias de lactação enquanto que as concentrações de albumina diminuem e as concentrações de imunoglobulina de cadeia leve oscilam ao longo da lactação

- As concentrações de $\beta$-Lg diminuem ao longo da lactação e são maiores durante os primeiros dois meses

- A concentração de $\alpha$-La varia pouco durante a lactação e é máxima entre 30 e 60 dias de lactação

d. O número de lactações não influencia a concentração de proteína total no leite de cabras, porém a concentração de proteína do soro lácteo de cabras com 1 e 2 lactações é menor quando comparadas com cabras com mais de 3 
lactações e os teores de lactoferrina, albumina sérica, imunoglobulinas e $\beta$ Lg, são menores em cabras de primeira lactação

ESTUDO 4 - A análise dos resultados da avaliação da influência do isolamento bacteriano no proteinograma do leite de cabras permitiu as seguintes conclusões:

a. O isolamento bacteriano não influencia as concentrações de proteína total do leite e proteína do soro lácteo de cabras

b. Amostras com isolamento bacteriano apresentam maiores concentrações de lactoferrina e menores concentrações de $\beta$-Lg e $\alpha$-La;

ESTUDO 5 - A análise dos resultados da avaliação da Influência do vírus da artrite e encefalite caprina no proteinograma do leite de cabras permitiu as seguintes conclusões

a. O vírus da CAE não influencia as concentrações de proteína total do leite e proteína do soro lácteo de cabras;

b. As concentrações de lactoferrina são mais altas em amostras sororeagentes positivas ao CAEV determinando um fator imunossupressor;

c. As concentrações de $\alpha$-La são menores nas amostras sororeagentes positivas ao CAEV; 


\section{REFERÊNCIAS}

AKERS, R. M. Lactation and the mammary gland. lowa: Blackwell, 2002. p. 283

ALEXANDER, L. J.; HAYES, G.; BAWDEN, W.; STEWART, A. F.; MACKINLAY, A. G. Complete nucleotide sequence of the bovine $\beta$-lactoglobulin gene. Animal Biotechnology, v. 4, n. 1, p. 1-10, 1993.

ALMEIDA, J. F. Agentes infecciosos causadores de mastite e parâmetros físicoquímicos na qualidade do leite de cabra in natura. 2009. 106 p. Tese (Doutorado) - Faculdade de Medicina Veterinária, Universidade Federal Fluminense, Niteroi, 2009.

ARGÜELLO, A.; CASTRO, N.; ÁLVAREZ, S.; CAPOTE, J. Effects of the number of lactations and litter size on chemical composition and physical characteristics of goat colostrum. Small Ruminant Research, v. 64, n. 1-2, p. 53-59, 2006.

ASLAM, M.; HURLEY, W. L. Proteolysis of milk proteins during involution of the bovine mammary gland. Journal of Dairy Science, v. 80, n. 9, p. 2004-2010, 1997.

ASLAM, M.; JIMÉNEZ-FLORES, R.; KIM, H. Y.; HURLEY, W. L. Two-dimensional electrophoretic analysis of proteins of bovine mammary gland secretions collected during the dry period1. Journal of Dairy Science, v. 77, n. 6, p. 1529-1536, 1994.

AULDIST, M.; COATS, S.; ROGERS, G.; MCDOWELL, G. Changes in the composition of milk from healthy and mastitic dairy cows during the lactation cycle. Australian Journal of Experimental Agriculture, v. 35, n. 4, p. 427-436, 1995.

BANDEIRA, D. A.; DE CASTRO, R. S.; AZEVEDO, E. O.; DE SOUZA SEIXAS MELO, L.; DE MELO, C. B. Seroprevalence of caprine arthritis-encephalitis virus in goats in the Cariri region, Paraiba state, Brazil. The Veterinary Journal, v. 180, n. 3, p. 399-401, 2009.

BAROZA, P. F. J. Proteínas, enzimas e minerais na secreção láctea de cabras e vacas, nos primeiros $\mathbf{3 0}$ dias pós-parto, congelada ou não. 2007. $113 \mathrm{f}$.

Dissertação (Mestrado em Medicina Veterinária) - Faculdade de Ciências Agrárias e Veterinárias, Universidade Estadual Paulista, Jaboticabal, 2007.

BARTH, K.; AULRICH, K.; MÜLLER, U.; KNAPPSTEIN, K. Somatic cell count, lactoferrin and NAGase activity in milk of infected and non-infected udder halves of dairy goats. Small Ruminant Research, v. 94, n. 1-3, p. 161-166 2010.

BASCH, J. J.; DOUGLAS JR., F. W.; PROCINO, L. G.; HOLSINGER, V. H.; FARRELL JR, H. M. Quantitation of Caseins and Whey Proteins of Processed Milks and Whey Protein Concentrates, Application of Gel Electrophoresis, and Comparison with Harland-Ashworth Procedure. Journal Dairy Science, v. 68, n. 1, p. 23-31, 1985. 
BENEDET, H. D.; CARVALHO, M. W. Caracteriração do leite de cabra no Estado de Santa Catarina, Brasil. Ciência e tecnologia alimentar, v. 16, n. 2, p. 116-119, 1996.

BHOSALE, S. S.; KAHATE, P. A.; KAMBLE, K.; THAKARE, V. M.; GUBBAWAR, S. G. Effect of lactation on physico-chemical properties of local goat milk. Veterinary World, v. 2, n. 1, p. 17-19, 2009.

BIRGEL, D. B. Processo de secagem da glândula mamária de bovinos da raça Holandesa: avaliação física da involução da mama e das características físicoquímicas, celulares e microbiológicas da secreção láctea durante o período seco. 2006. 191 p. Dissetação (Mestrado em Medicina Veterinária) - Universidade de São Paulo, Faculdade de Medicina Veterinária e Zootecnia, São Paulo, 2006.

BIRGEL, E. H. Semiologia da glândula mamária de ruminantes. In: FEITOSA, F. L. Semiologia veterinária: a arte do diagnóstico. São Paulo: Roca 2004. p. 353-399

BIRGEL JUNIOR, E.; CESTARI, V.; SAMPAIO, R. M.; LARA, M. C. C. S.; BIRGEL, D. B.; RAIMONDO, R. F. S.; BRANDESPIM, F. B.; BIRGEL, E. H. Influêcia da infecção pelo vírus da artrite encefalite caprina nas características físicoquímicas e celulares do leite de caprinos. Arquivos do instituto biológico, v. 74, n. 3, p. 199-206, 2007.

BIRGEL JUNIOR, E. H. Características físico-químicas, celulares e microbiológicas do leite de bovinos das raças Holandesa, Gir e Girolando criados no Estado de São Paulo. 2006. 335 f. Tese (Livre-docência ) - Faculdade de Medicina Veterinária e Zootecnia, Universidade de São Paulo, São Paulo, 2006.

BLECK, G. T.; WHEELER, M. B.; HANSEN, L. B.; CHESTER-JONES, H.; MILLER, D. J. Lactose synthase components in milk: Concentrations of a-lactalbumin and $\beta 1,4-$ galactosyltransferase in milk of cows from several breeds at various stages of lactation. Reproduction in Domestic Animals, v. 44, n. 2, p. 241-247, 2009.

BOHLAND, E.; D'ANGELINO, J. L. Artrite encefalite caprina: avaliação dos aspectos produtivos e reprodutivos de animais infectados e não infectados. Brazilian Journal of Veterinary Research and Animal Science, v. 42, n. 2, p. 81-88, 2005.

BOTARO, B. G.; LIMA, Y. V. R. D.; AQUINO, A. A.; FERNANDES, R. H. R.; GARCIA, J. F.; SANTOS, M. V. D. Polimorfismo da beta-lactoglobulina não afeta as características físico-químicas e a estabilidade do leite bovino. Pesquisa

Agropecuária Brasileira, v. 42, n. 5, p. 747-753, 2007.

BOUTINAUD, M.; ROUSSEAU, C.; KEISLER, D. H.; JAMMES, H. Growth hormone and milking frequency act differently on goat mammary gland in late lactation. Journal of Dairy Science, v. 86, n. 2, p. 509-520, 2003.

BRANDESPIM, F. B. Características fisico-químicas e celulares na secreção láctea de caprinos da raça Saanen durante o processo de secagem da glândula mamária. 2007. 157 p. Dissertação (Mestrado em Medicina Veterinária) - Faculdade de Medicina Veterinária e Zootecnia, Universidade de São Paulo, São Paulo, 2007. 
BREW, K. Alfa-lactoalbumin In: FOX, P. F.; MCSWEENEY, P. L. H. Advanced dairy chemistry -1 proteins. Cork: Kluwer academic, 2003. p. 387-419

BRUNE, W.; ALFENAS, A. C. Modalidades da eletroforese In: ALFENAS, A. C. Eletroforese de isoenzimas e proteínas afins: fundamentos e aplicações em plantas e microrganismos. Viçosa: Universidade Federal de Viçosa, 1998. p. 574.

CAFFIN, J. P.; POUTREL, B. Physiological and pathological factors influencing bovine immunoglobulin G2 concentration in milk. Journal of Dairy Science, v. 71, n. 8, p. 2035-2043, 1988.

CAFFIN, J. P.; POUTREL, B.; RAINARD, P. Physiological and pathological factors influencing bovine alpha-lactalbumin and beta-lactoglobulin concentrations in milk. Journal of Dairy Science, v. 68, n. 5, p. 1087-1094, 1985.

CAFFIN, J. P.; POUTREL, B.; RAINARD, P. Physiological and pathological factors influencing bovine immunoglobulin G1 concentration in milk. Journal Dairy Science, v. 66, n. 10, p. $2161-2166,1983$.

CAJA, G.; SALAMA, A. A. K.; SUCH, X. Omitting the dry-off period negatively affects colostrum and milk yield in dairy goats. Journal of Dairy Science, v. 89, n. 11, p. 4220-4228, 2006.

CAPUCO, A. V.; WOOD, D. L.; BALDWIN, R.; MCLEOD, K.; PAAPE, M. J. Mammary cell number, proliferation, and apoptosis during a bovine lactation: relation to milk production and effect of bST. Journal of Dairy Science, v. 84, n. 10, p. 21772187, 2001.

CAPUCO, A. V.; ELLIS, S. E.; HALE, S. A.; LONG, E.; ERDMAN, R. A.; ZHAO, $\mathrm{X}$.; PAAPE, M. J. Lactation persistency: insights from mammary cell proliferation studies. Journal of animal science, v. 81 p. 18-31, 2003. Supplementum 3.Journal of animal science

CARNICELLA, D.; DARIO, M.; AYRES, M. C. C.; LAUDADIO, V.; DARIO, C. The effect of diet, parity, year and number of kids on milk yield and milk composition in Maltese goat. Small Ruminant Research, v. 77, n. 1, p. 71-74, 2008.

CECILIANI, F.; POCACQUA, V.; PROVASI, E.; COMUNIAN, C.; BERTOLINI, A.; BRONZO, V.; MORONI, P.; SARTORELLI, P. Identification of the bovine alpha 1acid glycoprotein in colostrum and milk. Veterinary Research, v. 36, n. 5-6, p. 735746, 2005.

CHANETON, L.; TIRANTE, L.; MAITO, J.; CHAVES, J.; BUSSMANN, L. E. Relationship between milk lactoferrin and etiological agent in the mastitic bovine mammary gland. Journal of Dairy Science, v. 91, n. 5, p. 1865-1873, 2008.

CHEN, J. C.; CHANG, C. J.; PEH, H. C.; CHEN, S. Y. Total protein and gammaglobulin contents of mammary secretion during early post-partum period of Nubian goats in the Taiwan area. Small Ruminant Research, v. 31, n. 1, p. 67-73, 1998. 
CHEN, P. W.; CHEN, W. C.; MAO, F. C. Increase of lactoferrin concentration in mastitic goat milk. Journal of Veterinary Medical Science, v. 66, n. 4, p. 345-350, 2004.

CHENG, J. B.; WANG, J. Q.; BU, D. P.; LIU, G. L.; ZHANG, C. G.; WEI, H. Y.; ZHOU, L. Y.; WANG, J. Z. Factors affecting the lactoferrin concentration in bovine milk. Journal of Dairy Science, v. 91, n. 3, p. 970-976, 2008.

CHIGERWE, M.; DAWES, M. E.; TYLER, J. W.; MIDDLETON, J. R.; MOORE, M. P.; NAGY, D. M. Evaluation of a cow-side immunoassay kit for assessing IgG concentration in colostrum. Journal of the American Veterinary Medical Association, v. 227, n. 1, p. 129-131, 2005.

CIAPPESONI, G.; PRIBYL, J.; MILERSKI, M.; MARES, V. Factors affecting goat milk yield and its composition. Czech Journal of animal science, v. 49, n. 11, p. 465-473, 2004.

CONESA, C.; SANCHEZ, L.; ROTA, C.; PEREZ, M. D.; CALVO, M.; FARNAUD, S.; EVANS, R. W. Isolation of lactoferrin from milk of different species: calorimetric and antimicrobial studies. Comparative Biochemistry and Physiology Part B: Biochemistry and Molecular Biology, v. 150, n. 1, p. 131-139, 2008.

CONTRERAS, A.; LUENGO, C.; SÁNCHEZ, A.; CORRALES, J. C. The role of intramammary pathogens in dairy goats. Livestock Production Science, v. 79, n. 23, p. 273-283, 2003.

CUNNIGAN, J. G. A glândula mamária. In: Tratado de fisiologia veterinária. Rio de Janeiro: Guanabara Koogan, 2004. p. 417-430.

CUTLIP, R. C.; JACKSON, T. A.; LAIRD, G. A. Immunodifusion test for ovine progressive pneumonia. American Journal of Veterinary Research, v. 38, n. 7, p. 1081-1084, 1977.

DAVIS, B. J. Disc electrophoresis - II Method and application to human serum proteins. Annals of the New York Academy of Sciences, v. 121, n. 2, p. 404-427, 1964.

DINGWELL, R. T.; KELTON, D. F.; LESLIE, K. E. Management of the dry cow in control of peripartum disease and mastitis. Veterinary Clinics of North America Food Animal Practice, v. 19, n. 1, p. 235-265, 2003.

ELLISON, R. T.; GIEHL, T. J.; LAFORCE, F. Damage of the outer membrane of enteric gram-negative bacteria by lactoferrin and transferrin. Infection Immunology, v. 56 n. 11 , p. $2774-2781,1988$.

FANTUZ, F.; POLIDORI, F.; CHELI, F.; BALDI, A. Plasminogen activation system in goat milk and its relation with composition and coagulation properties. Journal of Dairy Science, v. 84, n. 8, p. 1786-1790, 2001. 
FAO. FAOSTAT: agriculture. 2006. Disponível em: <faostat.fao.org>. Acesso em: 28 out. 2010.

FARRELL, H. M.; JIMENEZ-FLORES, R.; BLECK, G. T.; BROWN, E. M.; BUTLER, J. E.; CREAMER, L. K.; HICKS, C. L.; HOLLAR, C. M.; NG-KWAIHANG, K. F.; SWAISGOOD, H. E. Nomenclature of the Proteins of Cows' MilkSixth Revision. Journal of Dairy Science, v. 87, n. 6, p. 1641-1674, 2004.

FERNANDES, M. A. Características físico-químicas, celulares e microbiológicas do leite de cabras das raças Saanen e Alpina, criados no Estado de São Paulo. 2002. 152 p. Dissertação (Mestrado em Clínica Veterinária) - Faculdade de Medicina Veterinária e Zootecnia, Universidade de São Paulo, São Paulo, 2002.

FLEET, I. R.; PEAKER, M. Mammary function and its control at the cessation of lactation in the goat. The journal of physiology, v. 279, n. 1, p. 491-507, 1978.

FONSECA, L. F. L.; SANTOS, M. V. Qualidade do leite e controle da mastite. São Paulo: Lemos Editorial, 2000. p. 175

FORMAGGIONI, P.; SUMMER, A.; MALACARNE, M.; MARIANI, P. Milk protein polymorphism: detection and diffusion of the genetic variants in bos genus. Annali della Facoltà di Medicina Veterinaria, v. XIX, n. 1, p., 1999.

FORSBACK, L.; LINDMARK-MANSSON, H.; ANDREN, A.; SVENNERSTENSJAUNJA, K. Evaluation of quality changes in udder quarter milk from cows with lowto-moderate somatic cell counts. Animal, v. 4, n. 4, p. 617-626, 2010.

FOWLER, P. A.; KNIGHT, C. H.; FOSTER, M. A. Omitting the dry period between lactations does not reduce subsequent milk production in goats. Journal of Dairy Research, v. 58, n. 1, p. 13-19, 1991.

FOX, P. F. Milk: an overview In: THOMPSON, A.;BOLAND, M.; SINGH, H. Milk proteins: from expresssion to food. New Zealand: Academic Press, 2009. p. 1-44.

FRANDSON, R. D.; WILKE, W. L.; FAILS, A. D. Anatomia e fisiologia das glândulas mamárias. In: Anatomia e fisiologia dos animais de fazenda. Rio de Janeiro: Guanabara Koogan, 2005. p. 399-410.

GOMES, V.; DELLA LIBERA, A. M. M. P.; MADUREIRA, K. M.; ARAÚJO, W. P. Influência do estágio de lactação na composição do leite de cabras (Capra hircus). Brazilian Journ al of Veterinary Research and Animal Science, v. 41, n. 5, p. 339-342, 2004.

GREGORY, L.; BIRGEL JUNIOR, E. H.; LARA, M. C. C. S. H.; ANGELINI, M.; ARAÚJO, W. P.; RIZZO, H.; MAIORKA, P.; CASTRO, R. S.; KIRALY, A. C. M.; BENESI, F. J.; BIRGEL, E. H. Clinica features of indurative mastitis caused by caprine arthritis encephalitis virus. Brasilian journal of veterinary pathology, v. 2, n. 2, p. 64-68, 2009. 
GRUFFERTY, M. B.; FOX, P. F. Milk alkaline proteinase. Journal of Dairy Research, v. 55, n. 4, p. 609-630 1988.

GUILLOTEAU, P.; ROMÉ, V.; DELABY, L.; MENDY, F.; ROGER, L.; CHAYVIALLE, J. A. A new role of phosphopeptides as bioactive peptides released during milk casein digestion in the young mammal: Regulation of gastric secretion. Peptides, v. 30, n. 12, p. 2221-2227, 2009.

HAGGARTY, N. W. Minor proteins, bovine serum albumin and vitamin-binding proteins In: ROGINSKI, H.;FUQUAY, J. W.; FOX, P. F. Encyclopedia of dairy sciences. Werribee: Academic Press, 2003. p. 1939-1941

HAGIWARA, S.; KAWAI, K.; ANRI, A.; NAGAHATA, H. Lactoferrin concentrations in milk from normal and subclinical mastitic cows. Journal of Veterinary Medical Science, v. 65 n. 3, p. 319-323, 2003.

HALLIDAY, R. Variation in immunoglobulin transfer from ewes to lambs. Annales de Recherches Veterinaires, v. 9, n. 2, p. 367-374, 1978.

HENG, G. B. Chemical composition of bovine colostrums. In: INTERNATIONAL CONFERENCE OF FOOD SCIENCE AND TECHNOLOGY, 3. 1999. Trumbull. Anais... Trumbull: Food and Nutrition Press, 1999, p. 405-411.

HILLIER, R. M. The quantitative measurement of whey proteins using polyacrylamide-gel electrophoresis. Journal of Dairy Research, v. 43, n. 2, p. 259265, 1976.

HISS, S.; MEYER, T.; SAUERWEIN, H. Lactoferrin concentrations in goat milk throughout lactation. Small Ruminant Research, v. 80, n. 1-3, p. 87-90, 2008.

HOLST, B. D.; HURLEY, W. L.; NELSON, D. R. Involution of the bovine mammary gland: histological and ultrastructural changes. Journal of Dairy Science, v. 70, n. 5, p. 935-944, 1987.

HÖTZEL, I.; BASTOS, E. S.; RAVAZZOLLO, A. P.; MOOJEN, V. Carpine arthritisencephalitis virus: isolation and identification in Rio Grande do Sul, Brazil. Brazilian Journal of Medical and Biological Research, v. 23, n. 11, p. 1175-1173, 1993.

HURLEY, W. L. Immunoglobulins in mammary secretions In: FOX, P. F.; MCSWEENEY, P. L. H. Advanced dairy chemistry -1 proteins. Cork: Kluwer academic, 2003. p. 421-447

HURLEY, W. L. Mammary gland function during involution. Journal of Dairy Science, v. 72, n. 6, p. 1637-1646, 1989.

HURLEY, W. L.; REJMAN, J. J. [beta]-Lactoglobulin and [alpha]-Lactalbumin in mammary secretions during the dry period: parallelism of concentration changes. Journal of Dairy Science, v. 69, n. 6, p. 1642-1647, 1986. 
HURLEY, W. L.; REJMAN, J. J. Bovine lactoferrin in involuting mammary tissue. Cell Biology International, v. 17, n. 3, p. 283-289, 1993.

HURLEY, W. L.; JUNIOR, J. A. F. Mammary gland: growth, development and involution. In: ROGINSKI, H.;FUQUAY, J. W.; FOX, P. Encyclopedia of dairy sciences. San Diego: Academic Press 2003. p. 1689-1697

HYVÖNEN, P.; KÄYHKÖ, S.; TAPONEN, S.; VON WRIGHT, A.; PYÖRÄLÄ, S. Effect of bovine lactoferrin on the internalization of coagulase-negative staphylococci into bovine mammary epithelial cells under in-vitro conditions. Journal of Dairy Research, v. 76, n. 2, p. 144-151, 2009.

IBGE. Pesquisa pecaria municipal (1995 a 2006). Instituto Brasileiro de Geografia e Estatística. 2006. Disponível em: <sidra.ibge.gov.br>. Acesso em: 06 dez. 2010.

JACOBINSON, N. L.; MC GILLIARD, A. D. Glândula mamária e lactação. In: Fisiologia dos animais domésticos. Rio de Janeiro: Guanabara Koogan, 1988. p. 745-759.

JAITNER, J.; NJIE, M.; CORR, N.; DEMPFLE, L. Milk production of west african dwarf goats in the Gambia. Tropical Animal Health and Production, v. 38, n. 3, p. 261-266, 2006.

JENNESS, R. The composition of milk. In: Lactation. New York: Academic Press, 1974. p. 3-107.

JOHKE, T.; HAGEMAN, E. C.; LARSON, B. L. Some immunological relationships of alfa-lactalbumin and beta-lactoglobulin in milks of various species. Journal of Dairy Science, v. 47, n. 1, p. 28, 1964.

KALA, S. N.; PRAKASH, B. Genetic and phenotypic parameters of milk yield and milk composition in two Indian goat breeds. Small Ruminant Research, v. 3, n. 5, p. 475-484, 1990.

KANEKO, J. J.; HARVEY, J. W.; BRUSS, M. L. Clinical biochemistry of domestic animals. San Diego: Academic Press, 2008. p. 932

KATO, K.; MORI, K.; KATOH, N. Different protein patterns in normal and mastitic milks as revealed by sodium dodecyl sulfate-polyacrylamide gel electrophoresis.

Nippon Juigaku Zasshi, v. 51, n. 6, p. 1275-1278, 1989.

KAWAI, K.; SHIMAZAKI, K.; HIGUCHI, H.; NAGAHATA, H. Antibacterial activity of bovine lactoferrin hydrolysate against mastitis pathogens and its effect on superoxide production of bovine neutrophils. Zoonoses and Public Health, v. 54, n. 3-4, p. 160164, 2007.

KAWAI, K.; HAGIWARA, S.; ANRI, A.; NAGAHATA, H. Lactoferrin concentration in milk of bovine clinical mastitis. Veterinary Research Communications, v. 23, n. 7, p. 391-398, 1999. 
KNIGHT, C. H. The importance of cell division in udder development and lactation. Livestock Production Science, v. 66, n. 2, p. 169-176, 2000.

KOLB, E. Fisiologia veterinária. Rio de Janeiro: Guanabara Koogan, 1984. p. 413430

KORHONEN, H.; MARNILA, P. Lactoferrin. In: ROGINSKI, H.;FUQUAY, J. W.; FOX, P. F. Encyclopedia of dairy sciences. Werribee: Academic Press, 2003. p. 19461950

KORYCHA-DAHL, M.; DUMAS, B. R.; CHENE, N.; MARTAL, J. Plasmin activity in milk. Journal of Dairy Science, v. 66, n. 4, p. 704-711, 1983.

KRIEG, N. R.; HOLT, J. G. Bergey's manual of systematic bacteriology. Baltimore: Williams \& Williams, 1984. p. 964

KUMAR, A.; ROUT, P. K.; ROY, R. Polymorphism of beta-lactoglobulin gene in Indian goats and its effect on milk yield. Journal of Applied Genetics, v. 47, n. 1, p. 49-53, 2006.

LAEMMLI, U. K. Cleavage of structural proteins during the assembly of the head of bacteriophage T4. Nature, v. 227, n. 5259, p. 680-685, 1970.

LANGONI, H.; DOMINGUES, P. F.; BALDINI, S. Mastite caprina: seus agentes e sensibilidade frente a antimicrobianos. Revista Brasileira de Ciência Veterinária, $v$. 13, n. 1, p. 51-54, 2006.

LARA, M. D. C. C. D. S. H. Artrite-encefalite dos caprinos: aspectos clínicos e epidemiológicos. 2002. 247 p. Tese (Doutorado em Clínica Veterinária) - Faculdade de Medicina Veterinária e Zootecnia, Universidade de São Paulo, São Paulo, 2002.

LARA, M. D. C. C. D. S. H.; BIRGEL JUNIOR, E. H.; GREGORY, L.; BIRGEL, E. H. Aspectos clínicos da artrite-encefalite dos caprinos. Arquivos do instituto biológico, v. 57, n. 6, p. 736-740, 2005.

LARSON, B. L.; KENDALL, K. A. Protein production in the bovine - daily production of the specific milk proteins during the lactation period. Journal of Dairy Science, $v$. 40, n. 4, p. 377-386, 1957.

LARSON, B. L.; HEARY JR., H. L.; DEVERY, J. E. Immunoglobulin production and transport by the mammary gland. Journal of Dairy Science, v. 63, n. 4, p. 665-671, 1980.

LEITE, B. L. S.; MODOLO, J. R.; PADOVANI, C. R.; STACHISSINI, A. V. M.; CASTRO, R.; SIMÕES, L. B. Avaliação da taxa de ocorrência da artrite-encefalite caprina a vírus pelas reginais do Escritório de Defesa Agropecuária do Estado de São Paulo, Brasil, e seu mapeamento por meio do sistema de informações geográficas. Arquivos do instituto biológico, v. 71, n. 1, p. 21-26, 2004. 
LEITNER, G.; MERIN, U.; SILANIKOVE, N. Changes in milk composition as affected by subclinical mastitis in goats. Journal of Dairy Science, v. 87, n. 6, p. 1719-1726, 2004.

LENNETTE, E. H. Manual of clinical microbiology. Washington: American Society for Microbiology, 1985. p. 1149

LERONDELLE, C.; GREENLAND, T.; JANE, M.; MORNEX, J. F. Infection of lactating goats by mammary instillation of cell-borne Caprine Arthritis-Encephalitis Virus. Journal of Dairy Science, v. 78, n. 4, p. 850-855, 1995.

LEVIEUX, D. Colostrum, a milk particularly rich in numerous components. Is it possible to detect its unlawful addition in milk supplies? Lait, v. 79, n. 5, p. 465-488, 1999.

LEVIEUX, D.; OLLIER, A. Bovine immunoglobulin G, beta-lactoglobulin, alphalactalbumin and serum albumin in colostrum and milk during the early post partum period. Journal of Dairy Research, v. 66, n. 3, p. 421-430, 1999.

LEVIEUX, D.; MORGAN, F.; GENEIX, N.; MASLE, I.; BOUVIER, F. Caprine immunoglobulin $\mathrm{G}, \beta$-lactoglobulin, $\alpha$-lactalbumin and serum albumin in colostrum and milk during the early post partum period. Journal of Dairy Research, v. 69, n. 3, p. 391-399, 2002.

LEY, J. M.; JENNESS, R. Lactose synthetase activity of alfa-lactalbumins from several species. Archives of Biochemistry and Biophysics, v. 138, n. 2, p. 464, 1970.

LINZELL, J. L.; PEAKER, M. Changes in colostrum composition and permeability of mammary epithelium at about time of parturition in goat. Journal of Physiology, v. 243, n. 1, p. 129-151, 1974.

LINZELL, J. L.; PEAKER, M. Permeability of mammary ducts in lactanting goat. Journal of Physiology, v. 213, n. 2, p. 48-49, 1971.

LÖNNERDAL, B. Lactoferrin. In: FOX, P. F.; MCSWEENEY, P. L. H. Advanced dairy chemistry - 1 protein. Cork: Kluwer academic, 2003. p. 449-466

LOPEZ, J. W.; ALLEN, S. D.; MITCHELL, J.; QUINN, M. Rotavirus and Cryptosporidium shedding in dairy calf feces and its relationship to colostrum immune transfer. Journal of Dairy Science, v. 71, n. 5, p. 1288-1294, 1988.

MACCIOTTA, N. P. P.; FRESI, P.; USAI, G.; CAPPIO-BORLINO, A. Lactation curves of Sarda breed goats estimated with test day models. Journal of Dairy Research, v. 72, n. 4, p. 470-475, 2005.

MACEDO, V. D. P.; DAMASCENO, J. C.; SANTOS, G. T. D.; MARTINS, E. N.; MACEDO, F. D. A. F. D. Comportamento da curva de lactação de cabras mestiças Saanen em função da suplementação de concentrado e do sistema de produção.

Revista Brasileira de Zootecnia, v. 30, n. 6s, p. 2093-2098, 2001. 
MADSEN, B. D.; RASMUSSEN, M. D.; NIELSEN, M. O.; WIKING, L.; LARSEN, L. $B$. Physical properties of mammary secretions in relation to chemical changes during transition from colostrum to milk. Journal of Dairy Research, v. 71, n. 3, p. 263-272, 2004.

MARNILA, P.; KORHONEN, H. Immunoglobulin. In: ROGINSKI, H.;FUQUAY, J. W.; FOX, P. F. Encyclopedia of dairy sciences. Werribee: Academic Press, 2003. p. 1950-1956

MASSON, P. L.; HEREMANS, J. F. Lactoferrin in milk from different species. Comparative Biochemistry and Physiology Part B: Biochemistry and Molecular Biology, v. 39, n. 1, p. 119-129, 1971.

MAYER, G. Immunoglobulins: structure and function. [200-]. Disponível em: <www.pathmicro.med.sc.edu/mayer/lgStruct2000.htm>. Acesso em: jul. 2009.

MICUSAN, V. V.; BORDUAS, A. G. Preferential transport into colostrum of Fc fragment derived from serum IgG1 immunoglobulin in the goat. Research in Veterinary Science, v. 21, n. 2, p. 150-154, 1976.

MILLER, N.; DELBECCHI, L.; PETITCLERC, D.; WAGNER, G. F.; TALBOT, B. G.; LACASSE, P. Effect of stage of lactation and parity on mammary gland cell renewal. Journal of Dairy Science, v. 89, n. 12, p. 4669-4677, 2006.

MIOČ, B.; PRPIĆ, Z.; VNUČEC, I.; BARAĆ, Z.; SUŠIĆ, V.; SAMARŽIJA, D.; PAVIĆ, V. Factors affecting goat milk yield and composition. Mljekarstvo, v. 58, n. 4, p. 305-313, 2008.

MOATSOU, G.; MOSCHOPOULOU, E.; MOLLÉ, D.; GAGNAIRE, V.; KANDARAKIS, I.; LÉONIL, J. Comparative study of the protein fraction of goat milk from the Indigenous Greek breed and from international breeds. Food Chemistry, v. 106, n. 2, p. 509-520, 2008.

MOOJE, V.; CORREA SOARES, C.; RAVAZZOLLO, A. P.; DAL PIZZOL, M.; GOMES, M. Evidências da infecção pelo lentivirus (MAEDI/VISNA- Artrite-encefalite Caprina) em caprinos no Rio Grande do Sul, Brasil (Comunicação científica).

Arquivos da Faculdade de Medicina Veterinária da Universidade Federal do Rio Grande do Sul, v. 14, n. 14, p. 77-78, 1986.

MOREIRA, M. C.; OELEMANN, W. M. R.; LILENBAUM, W. Dados sorológicos da artrite encefalite caprina no Estado do Rio de Janeiro e avaliação do uso do índice clínico como ferramenta de diagnóstico Revista Brasileira de Medicina

Veterinária, v. 29, n. 2, p. 51-53, 2007.

NELSON, D. L.; COX, M. M. Lehninger principles of biochemistry. New York: Worth, 2000. p. 1152

NEVES, P. B.; MEDEIROS, E. S.; SÁ, V. V.; CAMBOIM, E. K. A.; GARINO JR., F.; MOTA, R. A.; AZEVEDO, S. S. Perfil microbiológico, celular e fatores de risco 
associados à mastite subclínica em cabras no semiárido da Paraíba. Pesquisa veterinária brasileira, v. 30, n. 5, p. 379-384, 2010.

OLIVEIRA, M. M. M.; CASTRO, R. S.; CARNEIRO, K. L.; NASCIMENTO, S. A.; CALLADO, A. K. C.; ALENCAR, C. S. A.; COSTA, L. S. P. Anticorpos contra lentivírus de pequenos ruminantes em caprinos e ovinos em abatedouros do estado de Pernambuco. Arquivo Brasileiro de Medicina Veterinária e Zootecnia, v. 58, n. 5, p. 947-949, 2006.

OSSOWKI, L. D.; BIEGEL, D.; REICH, E. Mammary plasminogen activators: correlation with involution, hormonal modulation and comparison between normal and neoplastic tissue. Cell, v. 16, n. 4, p. 929, 1979.

OSTERSEN, S.; FOLDAGER, J.; HERMANSEN, J. E. Effects of stage of lactation, milk protein genotype and body condition at calving on protein composition and renneting properties of bovine milk. Journal of Dairy Research, v. 64, n. 2, p. 207219, 1997.

OYENIYI, O. O.; HUNTER, A. G. Colostral constituents including immunoglobulins in the first three milkings postpartum. Journal of Dairy Science, v. 61, n. 1, p. 44-48, 1978.

PAHUD, J. J.; MACH, J. P. Identification of secretory IgA, free secretory piece and serum IgA in the ovine and caprine species. Immunochemistry, v. 7, n. 8, p. 679682, 1970.

PALMER, A. H. The preparation of a crystalline globulin from the albumin fraction of cow's milk. Journal of Biological Chemistry, v. 104, n. 2, p. 359-372, 1934.

PEREZ, M. D.; SANCHEZ, L.; ARANDA, P.; SALA, F. J.; CALVO, M. Time-course levels of alpha 2-macroglobulin and albumin in cow colostrum and milk and alpha 2macroglobulin levels in mastitic cow milk. Annales de Recherches Veterinaires, v. 20, n. 3, p. 251-258, 1989.

PEREZ, M. D.; SANCHEZ, L.; ARANDA, P.; ENA, J. M.; ORIA, R.; CALVO, M. Synthesis and evolution of concentration of beta-lactoglobulin and alfa-lactalbumin from cow and sheep colostrum and milk throughout early lactation. Cellular and Molecular Biology, v. 36, n. 2, p. 205-212, 1990.

PHILLIPPY, B. O.; MCCARTHY, R. D. Multi-origins of milk serum albumin in the lactating goat. Biochimica et Biophysica Acta (BBA) - General Subjects, v. 584, n. 2, p. 298-303, 1979.

PINHEIRO, R. R.; GOUVEIA, A. M. G.; ALVES, F. S. F. Prevalência da infecção pelo vírus da artrite encefalite caprina no estado do Ceará, Brasil. Ciencia Rural, v. 31, n. 3, p. 449-454, 2001.

POLITIS, I.; BARBANO, D. M.; GOREWIT, R. C. Distribution of plasminogen and plasmin in fractions of bovine milk. Journal of Dairy Science, v. 75, n. 6, p. 14021410, 1992. 
POLITIS, I.; LACHANCE, E.; BLOCK, E.; TURNER, J. D. Plasmin and plasminogen in bovine milk: Arelationship with involution? Journal of Dairy Science, v. 72, n. 4, p. 900-906, 1989.

POUTREL, B.; CAFFIN, J. P.; RAINARD, P. Physiological and pathological factors influencing bovine serum albumin content of milk. Journal of Dairy Science, v. 66, n. 3, p. 535-541, 1983.

PRASAD, H.; SENGAR, O. P. S. Milk yield and composition of the Barbari goat breed and its crosses with Jamunapari, Beetal and Black Bengal. Small Ruminant Research, v. 45, n. 1, p. 79-83, 2002.

QUILES, A.; GONZALO, C.; BARCINA, Y.; FUENTES, F.; HEVIA, M. Protein quality of Spanish Murciano-Granadina goat milk during lactation. Small Ruminant Research, v. 14, n. 1, p. 67-72, 1994.

QUILES, J. A.; GONZALO, C.; FUENTES, F.; HEVIA, M.; SANCHEZ, J. M. Protein compositivon and variation of caprine colostrum (Murcino-Granadina breed) by means of polyacrylamide- SDS gel-electrophoresis. Animal Production, v. 52, n. 1, p. 311-316, 1991.

RADOSTITS, O. M.; GAY, C. C.; BLOOD, D. C.; HINCHCLIFF, K. W. Doença dos recém-nascidos. In: . Clínica veterinária: tratado de doenças dos bovinos, ovinos, suínos, caprinos e equinos. Rio de Janeiro: Guanabara Koogan, 2000, p. $122-128$

RAIMONDO, R. F. S.; MIYIASHIRO, S. I.; BIRGEL JUNIOR, E. H. Influencia da fase de lactação nas proteínas do soro lácteo de vacas jersey. Ciência Animal Brasileira, v. 1, p. 732-738, 2009. Suplemento 1.Ciência Animal Brasileira

RAIMONDO, R. F. S. S., J. P. E.; MACHADO, R.; NUNES, M. T.; BIRGEL JUNIOR, E. H. Teores de proteína, gordura e sólidos totais no leite de vacas da raça Jersey criadas no Estado de São Paulo durante o primeiro mês de lactação. Brazilian Journal of Veterinary Research and Animal Science, v. 46, n. 5, p. 355 - 362 , 2009.

RAINARD, P.; POUTREL, B.; CAFFIN, J. P. Lactoferrin and transferrin in bovine milk in relation to certain physiological and pathological factors. Annales de Recherches Veterinaires, v. 13, n. 4, p. 321-328, 1982.

REJMAN, J. J.; HURLEY, W. L.; BAHR, J. M. Enzyme-Linked Immunosorbent Assays of bovine lactoferrin and a 39-Kilodalton protein found in mammary secretions during involution. Journal of Dairy Science, v. 72, n. 2, p. 555-560, 1989.

RIBEIRO, S. D. A. Caprinocultura: criação racional de caprinos. São Paulo: Nobel, 1998, $321 \mathrm{p}$. 
RICHARDSON, B. C. Variation of the concentration of plasmin and plasminogen in bovine milk with lactation. New Zealand Journal of Dairy Science and Technology, v. 18, n. 3, p. 247-252, 1983.

ROBBLEE, E. D.; ERICKSON, P. S.; WHITEHOUSE, N. L.; MCLAUGHLIN, A. M.; SCHWAB, C. G.; REJMAN, J. J.; ROMPALA, R. E. Supplemental lactoferrin improves health and growth of Holstein calves during the preweaning phase. Journal of Dairy Science, v. 86, n. 4, p. 1458-1464, 2003.

ROBITAILLE, G. Influence of kappa-casein and beta-lactoglobulin genetic variation the heat stability of milk Journal of Dairy Research, v. 62, n. 4, p. 593-600, 1995.

ROCHA, T. G.; FRANCIOSI, C.; NOCITI, R. P.; SILVA, P. C. D.; SAMPAIO, A. A. M.; FAGLIARI, J. J. Eletroforetograma das proteínas do soro lácteo de vacas canchim primíparas e pluríparas. Ciência Animal Brasileira, v. , p. 220-225, 2009. Suplemento 1. Trabalho apresentado no Congresso Brasileiro de Buiatria.Ciência Animal Brasileira

RODRIGUES, L.; SPINA, J. R.; ALMEIDA, I. A. M.; TEIXEIRA, A. C. D.; SANCHES, A.; RESENDE, K. T. Produção, composição do leite e exigências nutricionais de cabras Saanen em diferentes ordens de lactação. Acta Scientiarum. Animal Sciences, v. 28, n. 4, p. 447-452, 2006.

ROTA, A. M.; RODRÍGUEZ, P.; ROJAS, A.; MARTIN, L.; TOVAR, J. Evolucion de la cantidad y calidad de la leche de cabra verata a lo largo de la lactacion. Archivos de Zootecnia, v. 42, n. 157, p. 137-146, 1993.

RUDOVSKY, A.; LOCHER, L.; ZEYNER, A.; SOBIRAJ, A.; WITTEK, T. Measurement of immunoglobulin concentration in goat colostrum. Small Ruminant Research, v. 74, n. 1-3, p. 265-269, 2008.

SAFAYI, S.; THEIL, P. K.; ELBRØND, V. S.; HOU, L.; ENGBÆK, M.; NØRGAARD, J. V.; SEJRSEN, K.; NIELSEN, M. O. Mammary remodeling in primiparous and multiparous dairy goats during lactation. Journal of Dairy Science, v. 93 , n. 4 , p. 1478-1490, 2010.

SALAMA, A. A. K. Modifying the lactation curve in dairy goats: effects of milking frequency, dry period, and kidding internaval. 2005. 142 p. Tesis (Doctoral) Department de Ciencia Animal i dels Aliments, Universidad Autónoma de Barcelona, Bellaterra, 2005.

SAMPAIO JÚNIOR, A. Soroprevalência das lentiviroses de pequenos ruminantes em caprinos e ovinos no município de Teresina, Piauí, Brasil 2007. 68 p. Dissertação (Mestrado em Ciência Animal) - Faculdade de Medicina Veterinária, Universidade Federal do Piauí, Teresina, 2007.

SANCHEZ, L.; ARANDA, P.; PEREZ, M. D.; CALVO, M. Concentration of lactoferrin and transferrin throughout lactation in cow's colostrum and milk.

Biological Chemistry Hoppe-Seyler, v. 369, n. 9, p. 1005-1008, 1988. 
SANT'ANA, V. A. C. Proteinograma do leite de vacas: padrões e variabilidade. 2004. 161 p. Tese (Doutorado em Clínica Veterinária) - Faculdade de Medicina Veterinária e Zootecnia, Universidade de São Paulo, São Paulo, 2004.

SANT'ANA, V. A. C.; BIRGEL, E. H. Influência da fase de lactação no proteinograma do leite de vacas sadias. Archives of Veterinary Science, v. 12, p. 152, 2007. Suplemento.Archives of Veterinary Science

SANT'ANA, V. A. C.; BIRGEL, E. H. Obtenção do soro lácteo para o fracionamento das proteínas por eletroforese em gel de poliacrilamida. In: CONGRESSO LATINOAMERICANO DE BUIATRIA, 9. 2003. Salvador. Anais... Salvador: Associação Brasileira de Buiatria, 2003, p. 31.

SANTOS, T. G.; BERTOLINI, D. A.; MACEDO, F. A. F. P., I. N.; MARTINS, E. N. Variabilidade em imunoglobulina $G$ ( $(g G)$ no colostro de cabra de primeira ordenha e absorção intestinal de IgG pelos cabritos recém-nascidos. Brazilian Archives of Biology and Technology,, v. 37, n. 2, p. 285, 1994.

SARAIVA NETO, A. O.; CASTRO, R. S.; BIRGEL, E. H.; NASCIMENTO, S. A. Estudo soro-epidemiológico da artrite encefalite caprina em Pernambuco. Pesquisa veterinária brasileira, v. 14, n. 4, p. 121-124, 1995.

SASAKI, M.; DAVIS, C. L.; LARSON, B. L. Production and turnover of IGg1 and IGg2 immunoglubulins in bovine around parturition. Journal of Dairy Science, v. 59, n. 12, p. 2046-2055, 1976.

SAWYER, L. Beta - lactoglobulin In: FOX, P. F.; MCSWEENEY, P. L. H. Advanced dairy chemistry $\mathbf{- 1}$ protein. Cork: Kluwer academic, 2003. p. 319 - 386

SCHALM, O. W.; CARROLL, E. J.; JAIN, N. C. Bovine mastitis. Philadelphia: Lea \& Febiger, 1971. p. 360

SCHMIDT, V.; PINTO, A. T.; SCHNEIDER, R. N.; SILVA, F. F. P.; MELLO, F. A. Caracterização da mastite subclínica em caprinos produzidos em sistema orgânico no Rio Grande do Sul. Pesquisa veterinária brasileira, v. 29, n. 9, p. 774-778, 2009.

SGARBIERI, V. C. Propriedades fisiológicas-funcionais das proteínas do soro de leite. Revista de nutrição, v. 17, n. 4, p. 397, 2004.

SGARBIERI, V. C. Revisão: propriedades estruturais e físico-químicas das proteínas do leite. Brazilian Journal of Food Technology, v. 8, n. 1, p. 43-56, 2005.

SHAMAY, A.; SHAPIRO, F.; LEITNER, G.; SILANIKOVE, N. Infusions of casein hydrolyzates into the mammary gland disrupt tight junction integrity and induce involution in cows. Journal of Dairy Science, v. 86, n. 4, p. 1250-1258, 2003.

SHAMAY, A.; HOMANS, R.; FUERMAN, Y.; LEVIN, I.; BARASH, H.; SILANIKOVE, N.; MABJEESH, S. J. Expression of albumin in nonhepatic tissues 
and its synthesis by the bovine mammary gland. Journal of Dairy Science, v. 88, n. 2, p. 569-576, 2005.

SHAPIRO, A. L.; VIÑUELA, E.; V. MAIZEL, J. Molecular weight estimation of polypeptide chains by electrophoresis in SDS-polyacrylamide gels. Biochemical and Biophysical Research Communications, v. 28, n. 5, p. 815-820, 1967.

SHUICHI, K.; KUNIO, Y.; SADAKO, M.; YOSHIKAZU, K. Degradation of casein components by acid protease of bovine milk. Journal of Dairy Science, v. 63, n. 5, p. 701-704, 1980.

SILANIKOVE, N.; LEITNER, G.; MERIN, U.; PROSSER, C. G. Recent advances in exploiting goat's milk: quality, safety and production aspects. Small Ruminant Research, v. 89, n. 2-3, p. 110-124, 2010.

SILVA, J. S.; CASTRO, R. S.; MELO, C. B.; FEIJÓ, F. M. C. Infecção pelo vírus da artrite encefalite caprina no Rio Grande do Norte. Arquivo Brasileiro de Medicina Veterinária e Zootecnia, v. 57, n. 6, p. 727-731, 2005.

SMITH, K. L.; TODHUNTER, D. A. The physiology of mammary glands during the dry period and the relationship to infection. In: ANNUAL MEETING OF NATIONAL MASTITIS COUNCIL, 21. 1982. Louisville. Proceedings... Louisville: N.M.C., 1982, p. 87-100.

SMITH, M. C.; CUTLIP, R. Effects on infection with caprine arthritis-encephalitis virus on milk production in goats. Journal American Veterinary Medical Association, v. 193, n. 1, p. 63-67, 1988.

SMITHIES, O. Zone electrophoresis in starch gels: group variations in the serum proteins of normal human adults. The Biochemical Journal, v. 61, n. 4, p. 629-641, 1955.

SOBRINHO, P. A. M.; RAMOS, T. R. R.; FERNANDES, C. H. C.; CAMPOS, A. C.; COSTA, L. M.; CASTRO, R. S. Prevalence and associate factores to the infection for Lentivirus of small ruminants in caprine of Tocantins State, Brazil. Ciência Animal Brasileira, v. 11, n. 1, p. 117-124, 2010.

SORDILLO, L. M.; SHAFER-WEAVER, K.; DEROSA, D. Immunobiology of the mammary gland. Journal of Dairy Science, v. 80 n. 8, p. 1851-1865, 1997.

STORRY, J. E.; GRANDISON, A. S.; MILLARD, D.; OWEN, A. J.; FORD, G. D. Chemical-composition and coagulating properties of renneted milks from different breeds and species of ruminant. Journal of Dairy Research, v. 50, n. 2, p. 215-229, 1983.

STRANGE, E. D.; MALIN, E. L.; VAN HEKKEN, D. L.; BASCH, J. J. Chromatographic and electrophoretic methods used for analysis of milk proteins. Journal of Chromatography, v. 624, n. 1-2, p. 81-102, 1992. 
STRZAŁKOWSKA, N.; JÓŹWIK, A.; BAGNICKA, E.; KRZYŻEWSKI, J.; HORBAŃCZUK, K.; PYZEL, B.; HORBAŃCZUK, J. O. Chemical composition, physical traits and fatty acid profile of goat milk as related to the stage of lactation. Animal Science Papers and Reports, v. 27, n. 4, p. 311-320, 2009.

SUNG, Y. Y.; WU, T. I.; WANG, P. H. Evaluation of milk quality of Alpine, Nubian, Saanen and Toggenburg breeds in Taiwan. Small Ruminant Research, v. 33, n. 1, p. 17-23, 1999.

SWANSON, E. W. Comparing continuous milking with sixty-day dry periods in successive lactations. Journal of Dairy Science, v. 48, n. 9, p. 1205-1209, 1965.

TISELIUS, A. Electrophoresis of serum globulin. I. The Biochemical Journal, v. 31, n. 2, p. 313-317, 1937.

TIZARD , I. A. Imunidade no feto e no recém nascido. In: veterinária: uma introdução. São Paulo: Rocca, 2004, p. 233-246

TRALDI, A. S. Fisiopatologia da reprodução de caprinos. In: D’ANGELINO, J. L. Manejo, patologia e clínica de caprinos. São Paulo: Sociedade Paulista de Medicina Veterinária, 1985. p. p. 329-352

TSIOULPAS, A.; GRANDISON, A. S.; LEWIS, M. J. Changes in physical properties of bovine milk from the colostrum period to early lactation. Journal of Dairy Science, v. 90, n. 11, p. 5012-5017, 2007.

TSUJI, S.; HIRATA, Y.; MUKAI, F.; OHTAGAKI, S. Comparison of lactoferrin content in colostrum between different cattle breeds. Journal of Dairy Science, v. 73, n. 1, p. 125-128, 1990.

URECH, E.; PUHAN, Z.; SCHÄLLIBAUM, M. Changes in milk protein fraction as affected by subclinical mastitis. Journal of Dairy Science, v. 82, n. 11, p. 2402$2411,1999$.

WATHES, D. C.; CHENG, Z.; BOURNE, N.; TAYLOR, V. J.; COFFEY, M. P.; BROTHERSTONE, S. Differences between primiparous and multiparous dairy cows in the inter-relationships between metabolic traits, milk yield and body condition score in the periparturient period. Domestic Animal Endocrinology, v. 33, n. 2, p. 203225, 2007.

WEBER, K.; OSBORN, M. The Reliability of Molecular Weight Determinations by Dodecyl Sulfate-Polyacrylamide Gel Electrophoresis. Journal of Biological Chemistry, v. 244, n. 16, p. 4406-4412, 1969.

WENG, M. H.; CHANG, C. J.; CHEN, W. Y.; CHOU, W. K.; PEH, H. C.; HUANG, M. C.; CHEN, M. T.; NAGAHATA, H. Contribution of somatic cell-associated activation of plasminogen to caseinolysis within the goat mammary gland. Journal of Dairy Science, v. 89, n. 6, p. 2025-2037, 2006. 
YAHYAOUI, M. H.; PENA, R. N.; SANCHEZ, A.; FOLCH, J. M. Rapid communication: polymorphism in the goat beta-lactoglobulin proximal promoter region. Journal of animal science, v. 78, n. 4, p. 1100-1101, 2000.

YANG, X. Y.; CHEN, J. P.; ZHANG, F. X. Research on the chemical composition of Saanen goat colostrum. International Journal of Dairy Technology, v. 62, n. 4, p. 500-504, 2009.

YOSHIDA, S.; WEI, Z.; SHINMURA, Y.; FUKUNAGA, N. Separation of lactoferrin-a and -b from bovine colostrum. Journal of Dairy Science, v. 83, n. 10, p. 2211-2215, 2000.

ZAHRADDEEN, D.; BUTSWAT, I. S. R.; MBAP, S. T. Evaluation of some factors affecting milk composition of indigenous goats in Nigeria. Livestock Research for Rural Development. Cali: Fundación CIPAV, 2007. Disponível em: <www.Irrd.org/lrrd19/11/zahr19166.htm>. Acesso em: 06 set. 2010.

ZENG, S. S.; ESCOBAR, E. N. Effect of parity and milk production on somatic cell count, standard plate count and composition of goat milk. Small Ruminant Research, v. 17, n. 3, p. 269-274, 1995.

ZENG, S. S.; ESCOBAR, E. N.; POPHAM, T. Daily variations in somatic cell count, composition, and production of Alpine goat milk. Small Ruminant Research, v. 26, n. 3, p. 253-260, 1997.

ZHANG, Y.; BREW, K. Alfa-lactoalbumin In: ROGINSKI, H.;FUQUAY, J. W.; FOX, P. F. Encyclopedia of dairy sciences. Werribee: Academic Press, 2003. p. 1924-1932

ZIV, G.; GORDIN, S. Composition of bovine udder secretion during first half of dry period. Zentralblatt Für Veterinärmedizin Reihe A, v. 20, n. 4, p. 285-291, 1973. 